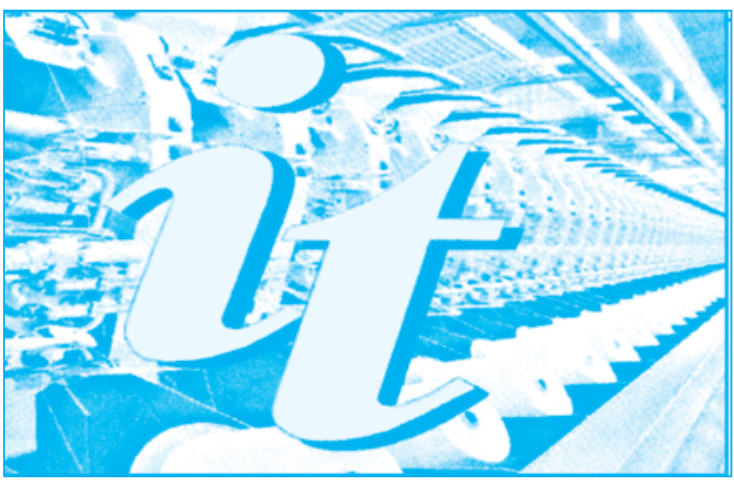

ISI rated journal, included in the ISI Master Journal List of the Institute of Science Information, Philadelphia, USA, starting with vol. 58, no. 1/2007, with impact factor 0.504 and AIS 0.046 in 2018.

The journal is indexed by CrossRef, starting with no. 1/2017 having the title DOI: https://doi.org/10.35530/IT.

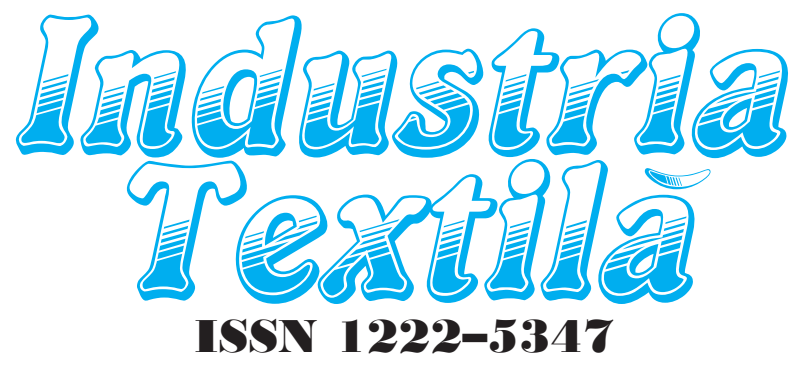

$5 / 2019$

Edited in 6 issues per year, indexed and abstracted in Science Citation Index Expanded (SciSearch $\left.{ }^{\circledR}\right)$, Materials Science Citation Index ${ }^{\circledR}$, Journal Citation Reports/Science Edition, World Textile

Abstracts, Chemical Abstracts, VINITI, Scopus, Toga FIZ technik ProQuest Central, Crossref

Edited with the Romanian Ministery of Research and Innovation support

\section{INIDUSTRIA TEXTHLA EDITORIAL BOARID:}

Dr. Eng. CARMEN GHITUULEASA GENERAL MANAGER

National R\&D Institute for Textiles and Leather Bucharest, Romania

Dr. Eng. SABINA OLARU CS II, EDITOR IN CHIEF

National R\&D Institute for Textiles and Leather, Bucharest, Romania

Dr. Eng. EMILIA VISILEANU CS I, HONORIFIC EDITOR

National R\&D Institute for Textiles and Leather, Bucharest, Romania Prof. XIANYI ZENG

Ecole Nationale Superieure des Arts et Industries Textiles (ENSAIT), France

Prof. Dr. Eng. LUIS ALMEIDA University of Minho, Portugal

Prof. Dr. STJEPANOVIČ ZORAN

University of Maribor, Faculty of Mechanical Engineering, Department of Textile Materials and Design, Maribor, Slovenia

Prof. Dr. Eng. ERHAN ÖNER Marmara University, Turkey

Prof. Dr. S. MUGE YUKSELOGLU Marmara University, Turkey Dr. MAZARI ADNAN ASSISTANT PROFESSOR

Department of Textile Clothing, Faculty of Textile Engineering, Technical University of Liberec Czech Republic

Dr. AMINODDIN HAJI

$P h D, M S c, B S c$, Textile Chemistry and Fiber Science ASSISTANT PROFESSOR

Textile Engineering Department

Yazd University, Yazd, Iran

Prof. Dr. Eng. CARMEN LOGHIN PRO-RECTOR

Faculty of Industrial Design and

Business Management, Technical University

"Gh. Asachi", laşi, Romania

Associate Prof. Dr. Eng. MARIANA URSACHE

$$
\text { DEAN }
$$

Faculty of Industrial Design and

Business Management, Technical University

"Gh. Asachi", laşi, Romania

Prof. Dr. GELU ONOSE

$$
\text { CSI }
$$

"Carol Davila" University of Medicine

and Pharmacy, Bucharest, Romania

Prof. Dr. DOINA I. POPESCU

The Bucharest University of Economic Studies, Bucharest, Romania

Prof. Dr. MARGARETA STELEA FLORESCU

The Bucharest University of Economic Studies, Bucharest, Romania

Prof. Dr. LUCIAN CONSTANTIN HANGANU

Technical University "Gh. Asachi", Iaşi, Romania
LIU YANHUI, JIANG RUITAO, WANG MIAN, FU SHAOJU, ZHANG PEIHUA

Degradation and biocompatibility behaviors of fully covered biodegradable polydioxanone biliary stent for human body

393-397

DIRGAR ESRA, ORAL OKSAN, OZDIL NILGUN

The performance properties of the yarn and fabrics produced from different types of cotton

RUI HUA YANG, QIAN QIAN DENG, CHUN PING XIE, WEI DONG GAO

Blending effect of rotor spun yarn with different blending methods

403-407

SHU-QIANG LIU, JUAN-JUAN YU, GAI-HONG WU, PENG WANG, MING-FANG LIU, YAO ZHANG, JIE ZHANG, XIAO-LONG YIN, FU LI, MAN ZHANG

Effect of silane KH550 on interface of basalt fibers (BFs)/poly (lactic acid)

(PLA) composites

408-412

VU THI HONG KHANH, NGUYEN THI HUONG

Influence of crosslinking agent on the effectiveness of flame retardant

treatment for cotton fabric

$413-420$

YING ZHANG, TAO LI, FENG-YUAN ZOU, CHENG-HAI YU, LEI DU

Facile fabrication of functional bra cup by an automated dispensing system

ADRIAN SĂLIŞTEAN, DOINA TOMA, SABINA OLARU, CLAUDIA NICULESCU

Integrated UAS system - Single skin textile wing

$426-429$

AMIRA LAKHAL, NEJIB SEJRI, FADHEL JAAFAR, YASSINE CHAABOUNI,

\section{MORCHED CHEIKHROUHOU}

Elaboration of a rest index for a sewing post in a clothing industry

$430-434$

ANDREJ CUPAR, ZORAN STJEPANOVIČ, SABINA OLARU,

GEORGETA POPESCU, ADRIAN SĂLIȘTEAN, ANDREJA RUDOLF

CASP methodology applied in adapted garments for adults and teenagers

with spine deformity

435-446

ABBES NEDRA, SEJRI NÉJIB, CHAABOUNI YASSINE, CHEIKHROUHOU MORCHED A new lean Six Sigma hybrid method based on the combination of PDCA and the DMAIC to improve process performance: Application to clothing SME

PELIN OFLUOGLU KUCUK, TURAN ATILGAN

Fashion designer selection with the method of GRA-based intuitionistic fuzzy multi-criteria decision making

JOVANA STEPANOVIĆ, TATJANA ŠARAC, NATAŠA RADMANOVAC,

DUŠAN TRAJKOVIĆ, JOVAN STEPANOVIĆ

Crimping analysis of textured polyester multifilament yarn

$463-469$

Y. BERRAK SARI, BENGI KUTLU

Adhesion improvement at polyester fabric-silicone rubber interface

by plasmas of argon and air to obtain conveyor belt

$470-480$

IRINA IONESCU, ADELA FLOREA, EMIL CONSTANTIN LOGHIN

Increasing effectiveness of the sewing methods for products with special destination

ANGELA DANILA, EMIL IOAN MUREŞAN, ALINA POPESCU,

VLAD ROTARU, CRISTINA ISTRATE

The potential of aroma textiles in North-East Romania

487-492

Web of Science Journal Category: Materials Science, Textiles

Aknowledged in Romania, in the engineering sciences domain

by the National Council of the Scientific Research from the Higher Education

(CNCSIS), in group $A$ 


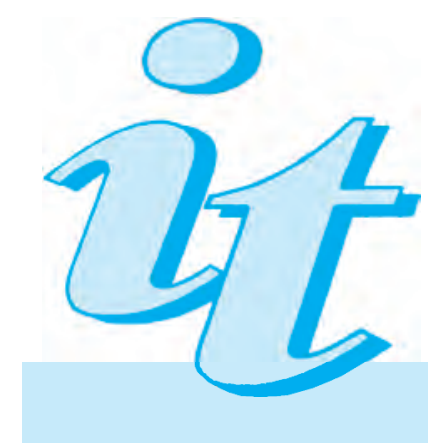

Scientific reviewers for the papers published in this number:

Prof. CHENHONG LONG, Institute for Frontier Materials, GTP Research Deakin University, Australia

Dr. RIADH ZOUARI, Master Management Qualité Matériaux, Université de Nice Sophia Antipolis, France

Prof. CHI WAI KAN, Institute of Textiles and Clothing, The Hong Kong Polytechnic University, China

Prof. HONGYAN WU, Hebei University of Science and Technology, China

Dr. FENJUAN SHAO, Donghua University, China

PhD. MELKIE TADESSE, University of Boras, Faculty of Textiles, Engineering and Business, Sweden

Assoc. Prof. MOISÉS GARCÍA MORALES, Facultad de Ciencias Experimentales, Department of Chemical Engineering, Physical Chemistry and Organic Chemistry, Huelva, Spania

Assoc. Prof. ZÜMRÜT ÜNAL, Ege University, Textile Engineering Department, Turkey

Prof. Assoc. Dr. ILDA KAZANI, Department of Textile and Fashion, Polytechnic University of Tirana, Albania

Assoc. Prof. IVELIN RAHNEV, Technical University of Sofia, College of Sliven, Bulgaria

PhD. KADIR BILISIK, Fiber Science and Engineering, Erciyes University, Turkey

Assoc. Prof. LILIANA INDRIE, The University of Oradea, Faculty of Energy Engineering, Department of Textiles,

Leather and Industrial Management, Romania

Dr. eng. VALENTIN BUTOESCU, National Institute for Aerospace Research "Elie Carafoli", Romania

Prof. TAREK SADRAOUI, Quantitative Methods Department of Quantitative methods, Tunisia

Prof. HATEM HADDA, National School of Engineers of Tunis, Tunis El Manar University, Tunisia

Prof. OMAR CHERKAOUI, École Supérieure des Industries du Textile et de l'Habillement (ESITH), Morocco

Prof. PhD. DOINA I. POPESCU, The Bucharest University of Economic Studies, Faculty of Management, Romania

Prof. PhD. KOLETA ZAFIROVA, Ss. Cyril and Methodius University in Skopje, Faculty of Technology and Metallurgy, Republic of Macedonia

Assoc. Prof. PhD. SVJETLANA JANJIĆ, University of Banja Luka, Faculty of Technology, Bosnia and Herzegovina

Assoc. Prof. Dr. SLAVICA BOGOVIĆ, Faculty of Textile Technology, University of Zagreb, Zagreb, Croatia

Assoc. Prof. Dr. INGA DĀBOLIŅA, Faculty of Material Science and Applied Chemistry, Institute of Design Technologies, Riga, Latvija

Prof. Dr. GÖKHAN ERKAN, Dokuz Eylül University, Textile Engineering Dep., Izmir, Turkey

\section{EDITORIAL STAFF}

General Manager: Dr. Eng. Carmen Ghițuleasa

Editor-in-chief: Dr. Eng. Sabina Olaru

Onorific editor: Dr. Eng. Emilia Visileanu

Graphic designer: Florin Prisecaru

Translator: Cătălina Costea

Site administrator: Constantin Dragomir

e-mail: industriatextila@ incdtp.ro

INDUSTRIA TEXTILA journal, edited by INCDTP BUCHAREST, implements and respects Regulation 2016/679/EU on the protection of individuals with regard to the processing of personal data and on the free movement of such data ("RGPD"). For information, please visit the Personal Data Processing Protection Policy link: e-mail DPO rpd@certex.ro

Journal edited in colaboration with Editura AGIR, 118 Calea Victoriei, sector 1, Bucharest, tel./fax: 021-316.89.92; 021-316.89.93; e-mail: editura@agir.ro, www.edituraagir.ro 


\title{
Degradation and biocompatibility behaviors of fully covered biodegradable polydioxanone biliary stent for human body
}

\author{
DOI: 10.35530/IT.070.05.1344
}

\section{ABSTRACT - REZUMAT}

\section{Degradation and biocompatibility behaviors of fully covered biodegradable polydioxanone biliary stent} for human body

This paper presents a study of the degradation and biocompatibility behaviors of fully covered biodegradable polydioxanone biliary stents (FCBPBSs) developed for human body. To investigate the relationship between the mechanical property of FCBPBSs and degradation time, nine FCBPBSs were prepared both by braid-hand method using a self-made cylinder of copper pipe mold and electrospinning. Meanwhile, the response of quality of FCBPBSs with increasing of degradation time was investigated. Futhermore, FCBPBSs and cells were cultured together to study the biocompatibility of FCBPBs indicating good biocompatibility.

Keywords: fully covered biodegradable polydioxanone biliary stents (FCBPBSs); degradation behaviors; biocompatibility; cell culture

\section{Comportamentul de degradare și biocompatibilitate al stentului biliar biodegradabil complet acoperit din polidioxanonă pentru corpul uman}

Această lucrare prezintă studiul asupra comportamentului de degradare si biocompatibilitate al stenturilor biliare biodegradabile complet acoperite din polidioxanonă (FCBPBS-uri), dezvoltate pentru organismul uman. Pentru a investiga relația dintre caracteristicile mecanice ale FCBPBS și timpul de degradare, nouă tipuri de FCBPBS au fost realizate, atât prin metoda de împletire manuală, folosind un cilindru din matriță de țeavă de cupru, cât și prin electrofilare. În paralel, a fost studiat nivelul de calitate al FCBPBS-urilor funcţie de timpului de degradare. În plus, FCBPBS-urile și celulele au fost cultivate împreună pentru a studia biocompatibilitatea acestora, obţinându-se rezultate satisfăcătoare.

Cuvinte-cheie: stenturi biliare biodegradabile complet acoperite din polidioxanonă (FCBPBS-uri); comportament de degradare; biocompatibilitate; cultură celulară

\section{INTRODUCTION}

Sung [1] studied that endoscopic biliary stenting has become a standard palliative treatment for obstructive jaundice due to malignancies of the pancreas and the hepatobiliary system. Since the late 1970s, despite the high initial success rate in achieving biliary drainage, endoscopic stenting therapy has been limited by the clogging of biliary stents, usually after four to five months, due to formation of adherent bacterial biofilm and accumulation of biliary sludge. In 1979, Soehendra [2] firstly described an endoscopic method for placing an internal drain in the bile-duct. Compared to the nasobiliary suction-tube, this method can guarantees the physiological flow of the bile into the duodenum, avoiding the inconvenience brought to patients, especially, for high-risk or inoperable cases, the method can be considered as a desirable alternative to choledochoduodenostomy. To date there are three types of biliary plastic stents applied in the biliary field, including polythylene biliary stent, polyurethane biliary stent and teflon biliary stent, respectively. Van Berkel [3] described a total of 9 different types of unused $10 \mathrm{~F}$ endoprostheses were examined by scanning electron microscopy (SEM): polyethylene Amsterdam-type, polyurethane Amsterdam-type, Teflon Amsterdam-type, and pointed out stents also had multiple particles protruding into the stent lumen with adjacent holes in the wall of the stent comparing other two type stent to explain the controversial results of clinical studies.

In 1985, Carrasco et al. [4] firstly pointed out expandable stents constructed of stainless-steel wire were inserted in the extrahepatic bile ducts of five animals to determine the effect of the endoprosthesis on the ductal wall, and found that expandable wire stents could be safely used to relieve biliary obstruction. Foerster [5] implanted Wallstent, a new self-expanding mesh stent, in seven patients for bridging choledochal stenosis, and on the basis of the current data endoscopic reconstructive splinting of benign choledochal stenosis would appear to be a promising technique.

Lammer [6] compared treatment with plastic versus metal stent at common bile duct obstruction due to malignancy, the mortality rate and obstruction rate were both significantly lower for metal stents than plastic stents. Restricture of bile duct was formed 
because pathological tissues grow through the mesh of stents, covered biliary stent was invented duo to this disadvantage above. Severini [7] investigated Prototypes of Gianturco-Rosch Z-stents coated with polycarbonate urethane (PCU) in the biliary tree of pigs, and demonstrated the biocompatibility, efficacy, and stability of PCU-coated GianturcoRosch stents in the biliary environment. Gregory [8] placed a new bioabsorbable biliary stent made by polylactic acid (PLA) monofilament into a porcine model and concluded that the bioabsorbable biliary stent, can be effectively deployed endoscopically, is self-expanding, is visualized radiographically, and remains patent up to 6 months. Giovanni et al. [9] have evaluated feasibility and safety of patients treated with biodegradable polydioxanone (PDO) biliary stents. The biodegradable biliary stent above mentioned is uncovered, however few fully covered biodegradable polydioxanone biliary stents (FCBPBSs) were studied based on their advantages that they can be degradable and as an obstacle which prevent the tissue from growing into the cavity of stents through the mesh.

In this paper, FCBPBSs were firstly fabricated by polydioxanone (PDO) monofilament, and secondly covered by electrospinning with polycaprolactone (PCL) material. PDO material, as the more widely used biodegradable material, is degraded with lowtoxicity to $\mathrm{CO}_{2}$ and $\mathrm{H}_{2} \mathrm{O}$, and has good biocompatibility and safety [10-11]. The monofilament with smooth surface and good mechanical property can be obtained by melt spinning processes [12]. PDO monofilament used for human body had further obtained the certification of FDA (U.S. Food and Drug Administration) [13]. Meanwhile, biodegradation and biocompatibility of FCBPBS were investigated.

\section{EXPERIMENTAL WORK}

\section{Specifications of FCBPBSs}

In this paper, FCBPBSs were fabricated by handing braid method. Firstly, non-covered biodegradable biliary stents (NBPBSs) were fabricated with PDO monofilament using a self-made cylinder of copper pipe mold. After finishing the braiding processes of the non-covered biliary stent, the heat setting process was carried out for the mold and NBPBSs in an environment of $75^{\circ} \mathrm{C}$ for about $15 \mathrm{~min}$ [14]. The detailed parameters of the PDO monofilament used for NBPBSs are shown in table 1. The structure of NBPBS was provided in figure 1, a.

Second, FCBPBSs were manufactured with NBPBSs by the method of electrospinning [15].

Polycaprolactone (PCL, Density: $1.14 \mathrm{~g} / \mathrm{cm}^{3}, \mathrm{Mn}=$ 80000 ) offered by Donghua University was used as film material on account of good property, including good biodegradation, good biocompatibility property. The organic solvent of PCL was mixed solution of dimethylformamide (DMF) and dichloromethane (DCM). Schematic representation of experimental

facility of electrospinning was shown in figure $1, b$. The positive electrode of high voltage power supply (HVPS) was connected with syringe needle, the size of syringe needle we used in experiment was 23G. The negative electrode of HVPS was connected with revolving reception facility on which NBPBS was put. Through the effect of voltage difference between the positive and negative electrode, film material in syringe was transported on the non-covered biodegradable Polydioxanone Biliary Stent to reach purpose of coating. To get nanofiber film, the preexperiment of electrospinning coating was conducted in advance, so, experiment parameters of electrospinning were set as shown in table 2.

FCBPBSs we design as shown in figure 1,c were conducted the compression tests preciously conducted by $\mathrm{Xu} \mathrm{H.J.} \mathrm{[16].} \mathrm{The} \mathrm{stent} \mathrm{specimens} \mathrm{were} \mathrm{com-}$ pressed to a deformation about $50 \%$ of the initial

Table 2

\begin{tabular}{|l|c|}
\hline \multicolumn{2}{|l|}{ EXPERIMENT PARAMETERS OF ELECTROSPINNING } \\
\hline Solute concentration of PCL $(\mathrm{g} / \mathrm{mL})$ & 0.18 \\
\hline Volume fraction of DMF $(\%)$ & 43 \\
\hline Voltage of HVPS (kV) & 15 \\
\hline $\begin{array}{l}\text { Distance between syringe needle and } \\
\text { revolving reception facility (cm) }\end{array}$ & 20 \\
\hline Reception time (h) & 2 \\
\hline $\begin{array}{l}\text { Rotating speed of revolving reception facility } \\
\text { (rpm) }\end{array}$ & 1000 \\
\hline
\end{tabular}

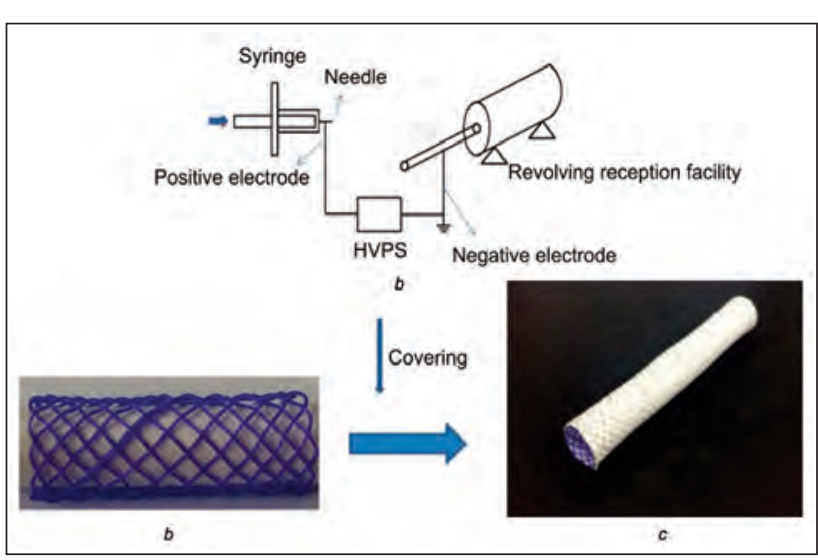

Fig. 1. $a-$ the appearance of NBPBS;

$b$ - the appearance of NBPBS; $c$ - experimental facility of electrospinning 


\begin{tabular}{|c|c|c|c|c|c|}
\hline \multicolumn{7}{|c|}{ THE STRUCTURE PARAMETERS OF FCBPBS } \\
\hline \multirow{3}{*}{ Material } & $\begin{array}{c}\text { Number of } \\
\text { specimens }\end{array}$ & $\begin{array}{c}\text { Braiding } \\
\text { number } \\
\text { (pins) }\end{array}$ & $\begin{array}{c}\text { External } \\
\text { diameter } \\
\text { (mm) }\end{array}$ & $\begin{array}{c}\text { Thickness } \\
\text { of film } \\
\text { (mm) }\end{array}$ & $\begin{array}{c}\text { Internal } \\
\text { diameter } \\
\text { (mm) }\end{array}$ \\
\hline \multirow{6}{*}{ PDO } & A2 & 8 & 8.83 & 0.07 & 8 \\
\cline { 2 - 6 } & A3 & 10 & 8.90 & 0.069 & 8 \\
\cline { 2 - 6 } & A4 & 12 & 8.92 & 0.068 & 8 \\
\cline { 2 - 6 } & B2 & 8 & 9.15 & 0.072 & 8 \\
\cline { 2 - 6 } & B3 & 10 & 9.17 & 0.07 & 8 \\
\cline { 2 - 6 } & B4 & 12 & 9.21 & 0.073 & 8 \\
\cline { 2 - 6 } & C2 & 8 & 9.52 & 0.068 & 8 \\
\cline { 2 - 6 } & C3 & 10 & 9.56 & 0.069 & 8 \\
\cline { 2 - 6 } & C4 & 12 & 9.67 & 0.071 & 8 \\
\hline
\end{tabular}

\section{Surface morphology of PDO} monofilament and FCBPBS after degradation

Based on the figures 2 and 3 , surface morphology of PDO monofilament and FCBPBS after degradation was very different with that of them before degrading. Before degradation, morphology of PDO monofilament is smooth and intact in the figure 2,a. Refer to figure $2, b$, the crack was generated on the surface of PDO monofilament after degradation. The surface of FCBPBS is intact, color of FCBPBS is vivid and the color of PDO monofilament is blue as depicted in figure 3 , a. However, with degrading, biliary stent diameter which is the internal diameter of biliary stent at a load speed of $20 \mathrm{~mm} / \mathrm{min}$. The size of the compression platen is $100 \mathrm{~mm}$ in length and $24.5 \mathrm{~mm}$ in width. In the compression process, the compression's initial height is defined as the position in which the compression platen just makes contact with the biliary stents. When compression displacement reaches $50 \%$ of the initial biliary stent diameter, the compression platen was stopped and the current compression force was defined as maximum compression in the whole compression process. After staying 5 second, the compression platen was back to original position at a speed of $20 \mathrm{~mm} / \mathrm{min}$. The structure parameters of FCBPBS9 were shown in table 3 .

\section{Degradation and biocompatibility}

FCBPBSs we design were dipped into tube with human bile with $\mathrm{pH} 7.4$, and incubated in surrounding of $5 \% \mathrm{CO}_{2}$ and $37^{\circ} \mathrm{C}$. The human bile in the tube with FCBPBSs change one time every week and the FCBPBSs were taken out every two weeks, washed by deionized water and freeze-dried. The compression force and quality of FCBPBSs was investigated every two weeks to study relationship between mechanical performances above and degradation time until FCBPBSs were completely degraded same with the relationship between quality of FCBPBSs and degradation time.

In order to evaluate the interaction between cells and materials (PCL and PDO), the method of in vitro cellular evaluation was used in this work. Firstly, the appropriate size of PDO monofilament and PCL film was prepared to put them in one well of 48-well plates. Human umbilical vein endothelial cells (HUVECs) were seeded on the surfaces of PCL film and PDO monofilament in 48-well plates, and then incubated in the conditions of $5 \% \mathrm{CO}_{2}, 95 \%$ humidity, and $37^{\circ} \mathrm{C}$. On day 1 and day 7 , F-actin/DAPI staining was conducted. The samples were observed using a Fluorescence Microscope (Carl Zeiss Inc., Oberkochen, Germany). the color of PDO monofilament was faded and PDO monofilament was fractured completely so that FCBPBSs were collapse indicating radial supporting force was lost in the last stage according to figure $3, b$.

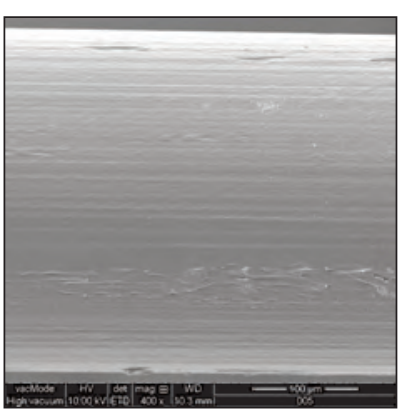

a

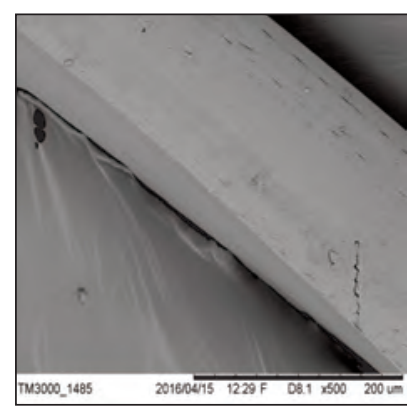

b
Fig. 2. $a$ - the surface morphology of PDO monofilament before degradation; $b$ - the surface morphology of PDO monofilament after degradation

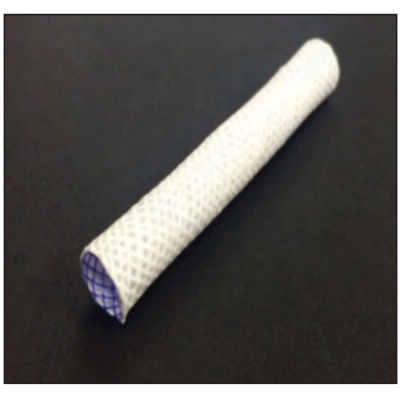

a

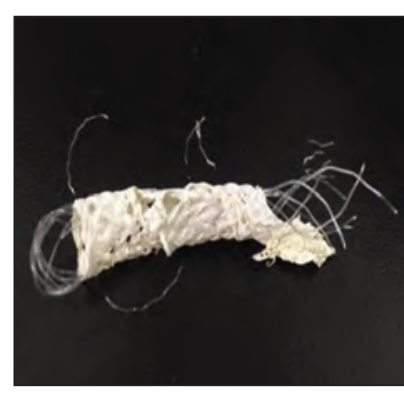

b
Fig. 3. a - The surface morphology of FCBPBS before degradation; $b$ - The surface morphology of FCBPBS after degradation

The mechanical property in the degradation process

In this work, the compression force value at the position that compression distance reaches $50 \%$ of the stent diameter is extracted and plotted into the compression force-degradation time curve of FCBPBSs in the compressing process. As depicted in the figure 4, the curves of all kinds of FCBPBSs we tested 


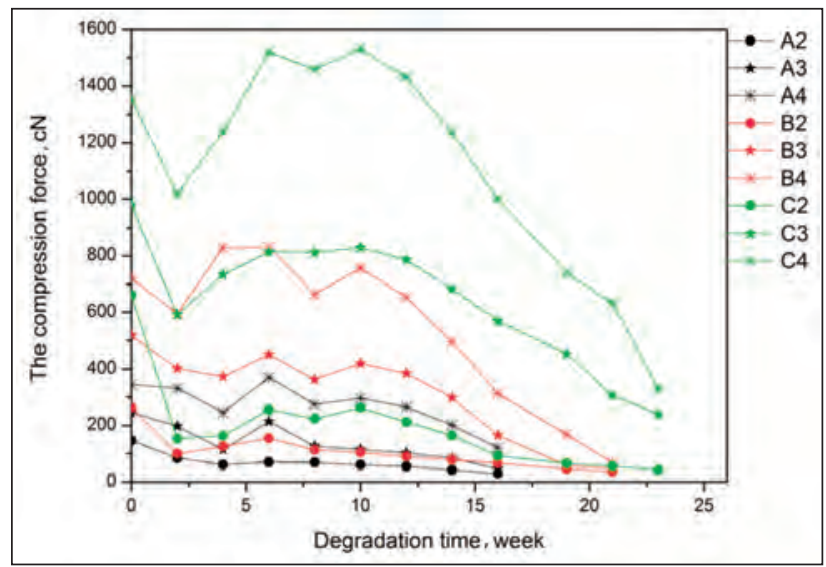

Fig. 4. The mechanical performance of different kinds of FCBPBSs in the degradation process

exhibited the same tendency, at second week of degradation process, the compression force decreased comparing with that of 0 week. With further degradation, the compression force began to increase and reach a peak about 10 weeks, at last, the compression force reduced until cannot be tested. It is also clear seen that FCBPBSs (C2, C3, C4) keep the most longest time of the compression force in the degradation process about 22 weeks, the middle is FCBPBSs (B2, B3, B4) about 20 weeks, and the shortest time is FCBPBSs (A2, A3, A4) about 16 weeks indicating that degradable time of FCBPBSs increased with growing of the PDO diameter of FCBPBSs under expected mechanical condition which can be tested.

\section{The quality variation of FCBPBSs with}

\section{degrading}

To investigate relation between quality of FCBPBSs and degradation time, the quality of FCBPBSs were measured every two weeks and end to test when the FCBPBSs cannot be compressed. As shown in the figure 5, quality of FCBPBSs decreased with growing of the degradation time, different kinds of FCBPBSs have same variation tendency above. Before 8 weeks, the slope of quality-degradation time curves of different kinds of FCBPBSs were very slow to drop, indicating that quality loss of FCBPBSs was very small, however, quality loss of FCBPBSs began to quickly fall down after eighth week, and dramatically declined in the last four weeks.

\section{Biocompatibility of FCBPBSs}

In order to evaluate the interaction between cells and materials (PCL and PDO), HUVECs were seeded on the surfaces of PCL film and PDO monofilament in 48-well plates. As depicted in the figure $6, a$, the most amount of HUVECs survived and grow on the surface of PCL after the one day culture, after cell culture of Day 7, cell cytoskeleton (green) and nuclei (blue) of HUVECs on the surface of PCL spread bigger than that of Day 1 indicating good biocompatibility between cell and PCL film. As shown in figure 6, $b$, comparing to Day 1, larger amount of HUVECs

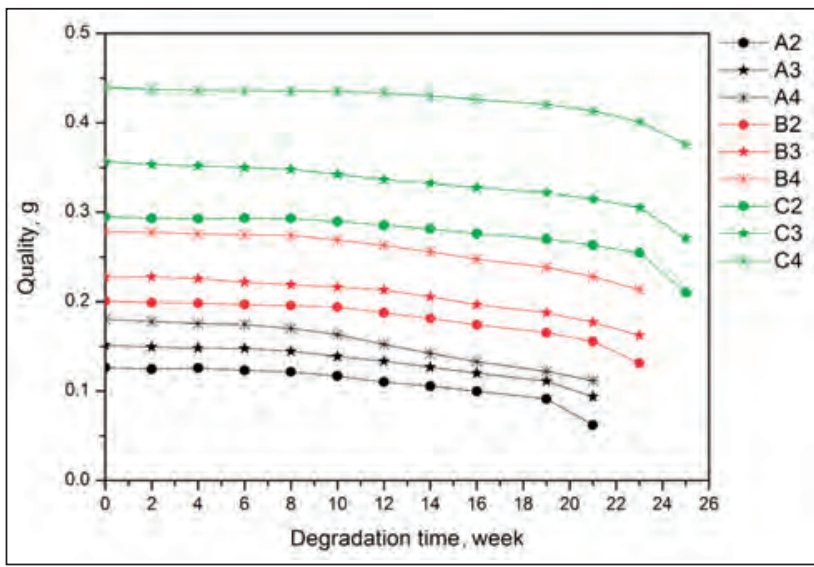

Fig. 5. The quality variation of different kinds of FCBPBSs in the degradation process

stretched on the surface of PDO suggesting that the high interaction between cell and PDO. Fluorescence images of HUVECs like fibroblast-like morphology indicated that materials of PDO and PCL dose not interfere with the adhesion properties of the cell, confirming strong affinity of materials towards HUVECs.

\section{CONCLUSION}

Degradation and biocompatibility Behaviors of FCBPBSs for Human Body was investigated in this study, the conclusions was drawn as follows:

- Through degradation, the crack was generated on the surface of PDO monofilament and the PDO monofilament of FCBPBSs was fractured completely so that FCBPBSs were collapse indicating radial supporting force was lost;

- All kinds of FCBPBSs exhibit the same tendency in the degradation process, FCBPBSs $(\mathrm{C} 2, \mathrm{C} 3, \mathrm{C} 4)$ keep the most longest time of the compression force in the degradation process about 22 weeks,
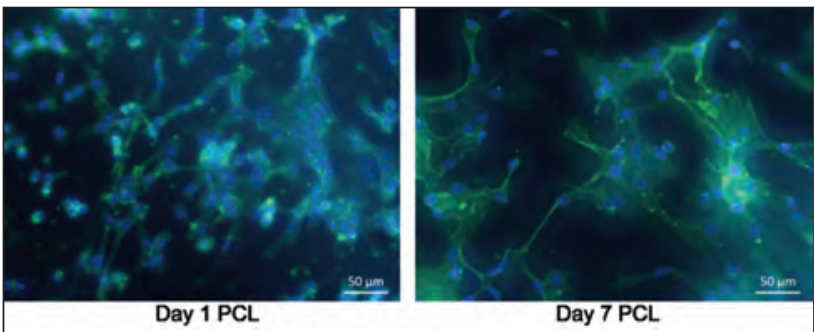

a

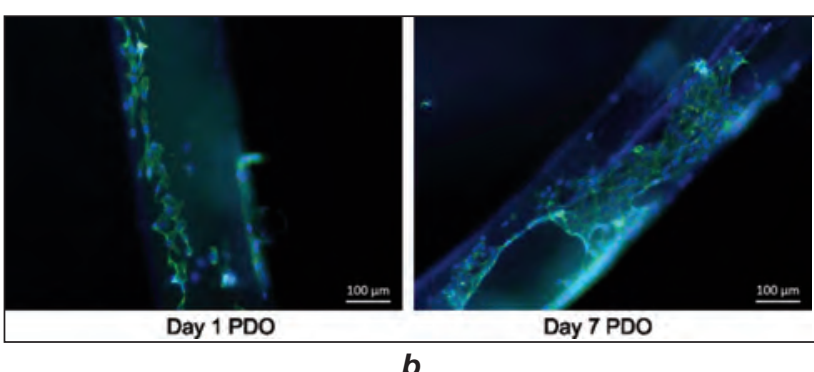

Fig. 6. Biology property of PCL and PDO:

a - Morphology of HUVECs toward PCL; $b$ - Morphology of HUVECs toward PDO. Cytoskeleton of HUVECs was stained for $\mathrm{F}$-actin (green) and nuclei of HUVECs were tagged with DAPI (blue) 
the middle is FCBPBSs (B2, B3, B4) about 20 weeks, and the shortest time is FCBPBSs (A2, A3, A4) about 16 weeks indicating that degradable time of FCBPBSs increased with growing of the PDO diameter of FCBPBSs;

- The quality loss of FCBPBSs was very little in front 8 weeks of whole degradation process, however, quality loss of FCBPBSs began to quickly fall down after eighth week, and dramatically declined in the last four weeks in the whole degradation process;
- By culturing the HUVECs with PCL film and PDO monofilament together, PCL film and PDO monofilament exhibit good biocompatibility.

\section{ACKNOWLEDGEMENTS}

This work was supported by "111 Project" - Biomedical Textile Materials Science and Technology (B07024), Study Abroad Program for Excellent Ph.D Students of Guangxi Zhuang Autonomous Region. The authors would like to express their appreciation for support from their class-

\title{
REFERENCES
}

[1] Sung, J.Y., Chung, S.C., Endoscopic stenting for palliation of malignant biliary obstruction: a review of progress in the last 15 years, In: Dig Dis Sci, 1995, 40, 6, 1167-1173

[2] Soehendra, N., Reynders-Fredeix, V., Palliative bile duct drainage. A new endoscopic method of introducing a transpapillary drain, In: Endoscopy, 1980, 12, 1, 8-11

[3] VanBerkel, A.M., VanMarle, J., VanVeen, H., A scanning electron microscopic study of biliary stent materials, In: Gastrointest Endosc, 2000, 51, 1, 19-22

[4] Carrasco, A.B., Wallace, N., Chamsangavej, H.P., Expandablebiliary endoprosthesis: an experimental study, In: AJR, 1985, 145, 1279-12

[5] Foerster, E.C., Hespffer, N., Domschke, W., Bridging of benigncholedochal stenoses by endoscopic retrograde implantion of mesh stents, In: Endoscopy, 1991, 23, 3, 133-137

[6] Lammer, J., Hausegger, K.A., Fluckiger, F., Common bile duct obstruction due to malignancy: treatment with plastic versusmetal stents, In: Radiology, 1996, 201, 167-172

[7] Severini, A., Mantero, S., Tanzi, M.C., In vivo study of polyurethane-coated Gianturco-Rosch biliary Z-stent, In: Cardiovasc Intervent Radiol, 1999, 22, 6, 510-514

[8] Gregory, G., Janak, S., Anthony, C.D., Invivo evaluation of a new bioabsorbable self-expanding biliary stent, In: Gastrointest Endosc, 2003, 58, 5, 777-784

[9] Mauri, G., Michelozzi, C., Melchiorre, F., Biodegradable biliary stent implantation in the treatment of benign bilioplastic-refractory biliary strictures: preliminary experience, In: European radiology, 2013, 23, 3304-10

[10] Zhai, W.Q., Zhen, H.Y., Xing, H.C., The in vitro degradation study of two degradable intravascular stents materials, In: Proceedings of 2011 International Forum Biomedical Textile Materials, Shanghai, China, 2011, 1

[11] Zhai, W.Q., Zhen, H.Y., Xing, H.C. The in vitro degradation study of biodegradable intravascular stents of two different materials, In: Proceedings of 2012 International Forum Biomedical Textile Materials, Shanghai, China, 2012, 1

[12] Wang, Y.H., Dou, H.J., Dynamic mechanical properties of biodegradable stents, In: Journal of Shanghai Jiao Tong University, 2010, 44, 11, 1605-1609

[13] Docob, D.F., Sacristan, P.C., Flor, C.B., Randomized clinical study of polydioxanone and nylon sutures for Laparotomy closure in high-risk patients, In: Cirugia Espanola, 2006, 79, 5, 305-309

[14] Liu, Y.H, Zhang, P.H., Characterization and modeling of compression behaviors of biodegradable polydioxanone biliary stent for human body, In: Industria Textila, 2016, 67, 1, 62-70

[15] Bing, J.Z, Yuan, Y.L., Yue, H. L., The Biocompatibility Between Electrospinning Scaffold of PCL and PDLSCs (in chinese), In: Journal of Clinical Stomatology, 2014, 30, 269-72

[16] Xu, H., Wang, C., Que, Z., Zhang, P., Preparation and Radial Compression Performance of PDO Intravascular Stents. In: Journal of Donghua University Natural Science Edition, 2014, 40, 418-23

\section{Authors:}

LIU YANHUI $1,2,3^{*}$, JIANG RUITAO ${ }^{2,3^{*}}$, WANG MIAN ${ }^{4}$, FU SHAOJU ${ }^{2,3}$, ZHANG PEIHUA ${ }^{2,3}$

${ }^{1}$ College of Textiles \& Clothing, State Key Laboratory of Bio-Fibers and Eco-Textiles, Qingdao University ${ }^{2}$ College of Textile, Donghua University

${ }^{3}$ Key of Laboratory of Textile Science \&Technology, Ministry of Education, China Technology, 2999 North Renmin Road, Shanghai, 201620, P.R.China

${ }^{4}$ School of Chemistry and Chemical Engineering, Guangxi University, Nanning 53004, China

*These authors contributed equally to this work and should be considered co-first authors e-mail: chainliuyanhui1@163.com, phzh@dhu.edu.cn

\author{
Corresponding author: \\ ZHANG PEIHUA \\ e-mail: phzh@dhu.edu.cn
}




\section{The performance properties of the yarn and fabrics produced from different types of cotton}

DOI: 10.35530/IT.070.05.1651

\section{ABSTRACT - REZUMAT}

\section{The performance properties of the yarn and fabrics produced from different types of cotton}

In this study, performance properties of single jersey knitted fabrics made from Aegean cotton, Supima cotton and Giza cotton yarns are investigated. Firstly, Uster parameters and breaking strength of the yarns were examined and then the properties of the fabrics knitted from these yarns were evaluated statistically. The significance levels of the relationship between the measured parameters were determined. Considering the results obtained with the mechanical properties of the fabrics with Uster analysis applied to these yarns, it is seen that the yarns made from Supima and Giza cotton fibers in extra long fiber category have more smooth, less hairiness, contain less neps and the fabrics knitted with these yarns have high mechanical properties.

Keywords: Supima cotton, Giza cotton, Aegean cotton, fabric, bursting strength.

Proprietățile de performanță ale firelor și tricoturilor realizate din diferite tipuri de fibre de bumbac

În cadrul acestui studiu, au fost analizate proprietățile de performanță ale tricoturilor glat realizate din fire de bumbac Aegean, de bumbac Supima și de bumbac Giza. În primul rând, au fost analizaţi parametrii Uster și rezistența la rupere a firelor și apoi au fost evaluate statistic proprietățile tricoturilor obţinute din aceste fire. Au fost calculate nivelurile de semnificație ale relației dintre parametrii determinaţi. Având în vedere rezultatele obținute prin analiza Uster, s-a concluzionat că firele realizate din fibre de bumbac Supima și de bumbac Giza, din categoria de fibre extralungi, sunt netede, au o pilozitate mai mică, conțin mai puține nopeuri, iar tricoturile obţinute din aceste fire prezintă proprietăți mecanice ridicate.

Cuvinte-cheie: bumbac Supima, bumbac Giza, bumbac Aegean, tricot, rezistență la plesnire

\section{INTRODUCTION}

Efforts for research and development activities in the textile industry, with increased demand for more comfortable, healthier and environmentally friendly products, focused on the utilisation of renewable and biodegradable resources as well as environmentally sound manufacturing processes in textiles. In this respect, new types of renewed fibers and cotton have gained importance as an alternative to traditional ones in apparel and home textile manufacturing [1]. Although there are many studies on the performance characteristics of various fabrics, but there are limited number of studies on different types of cotton.

Messiry \& Abd-Ellatif [2] studied the quality of the Egyptian cotton varieties in terms of morphological examination, strength of single fibers and other tuft properties determined by HVI.

Ozcelık et al. [3] studied on the structural properties of viscose, modal and lyocell fibers and yarns. Besides, they determined the influence of structural characteristics of the fibers on the performance properties of knitted fabrics such as pilling, bursting strength, color efficiency and thermo physiological properties. The results show that due to the fiber structure, pilling tendency of viscose fabric is higher compared to lyocell and modal grey fabrics. Since the tensile strength of lyocell fiber is higher, fabric bursting strength of lyocell fabric is higher than the modal and viscose fabrics.

Demiroz Gun et al. [4] examined dimensional and some physical properties of plain knitted fabrics made from 50/50 bamboo/cotton blended yarns. In order to see the differences and similarities, they compared the results with those for similar fabrics woven from 50/50 conventional viscose/cotton and $50 / 50$ modal/cotton blended yarns.

Dirgar [5] examined the performance characteristics of jersey knitted fabrics made of viscose, modal, lyocell and cupro yarns. In this study, performance properties of the fabrics such as fabric weight per unit area, thickness, bursting strength, abrasion resistance, fabric stretch, porosity, air permeability and pilling were evaluated statistically and the importance levels of the relationship between the measured parameters were determined.

Ozdemir [6] investigated the effects of yarn structural parameters and sizing on the physical properties of $100 \%$ cotton carded and combed ring yarns, sized with four different sizing agents.

In this study, performance characteristics of yarn and knitted fabrics produced from Aegean cotton, extra long-fiber Supima cotton (American cotton) and 
extra-long filament Giza cotton (Egypt cotton), having different fiber length and fiber fineness, were examined.

\section{Fibers used in the study}

Aegean Cotton: The cottons produced in some districts of İzmir, Aydın, Manisa, Muğla, Denizli, Çanakkale and Bursa are called Aegean Cotton and registered by İmir Commodity Exchange in this direction. Due to the climate, soil properties and ecological conditions, Aegean cotton is much better properties in terms of the brightness and softness and yarn (twist, tensile strength) properties according to other cotton [7]

Pima and Supima Cotton: A cotton fiber must be at least $34.9 \mathrm{~mm}$ (1 $3 / 8 \mathrm{inch})$ in length to be called extra-long fiber. Supima is one of the longest cotton varieties among the extra long fibers and has an average length of $36.5 \mathrm{~mm}$ (1 7/16 inch) [8].

Pima cotton is a kind of cotton known as extra long fiber cotton. These cottons are grown in countries such as America, Peru, Spain, Australia. Supima is an organization founded in 1954 by American Pima cotton growers. American Pima cottons can be sold to licensed producers who are members of the Supima organization all over the World [7].

The long fibers and the superior strength of the Supima result in a stronger yarn. This means that the Supima fabrics are thinner (lighter) and softer than the other types of cotton. The combination of fiber fineness, length and strength provides a silky feel, luxurious shine, less hairiness and more color alternatives [8-9].

Giza Cotton: Egyptian cotton is a world-wide variety of cotton. Its quality, fiber length, and fiber properties of this cotton do not change according to years. For this reason, it is suitable for obtaining high quality spinning results. In Egypt, medium-long, long and extra-long cotton fibers used in the production of high quality textile are produced and these products are named with the name Giza and a number next to it. The staple length of Giza cotton ranges from $3.8 \mathrm{~cm}$ to $5.7 \mathrm{~cm}$ (1.5 inches to 2.25 inches). Since the fiber length is longer than the other cotton types, it is possible to produce very fine yarn counts. Giza cotton fiber is very soft, glossy and high strength. One of the features that make Giza cotton high quality is its power to absorb liquid. Thanks to this feature, it allows the dye to be absorbed much better, thus ensuring that the product maintains its color tone and vitality for a longer period of time than other cottons. Giza cotton is preferred by the world brands that appeal to luxury and high income groups. Since Egyptian cotton is more resistant and softer than other cotton species, it is slightly more expensive in price [10].

\section{MATERIAL AND METHOD}

\section{Materials}

In this study, primarily, yarns made of different cotton fibers (Aegean cotton, extra-long fibrous American cotton (Supima) and extra-long fibrous Egyptian cotton (Giza)) and fabrics knitted made of these yarns, were used. The properties of these yarns are given in table 1.

Table 1

\begin{tabular}{|l|c|c|}
\hline \multicolumn{3}{|c|}{ THE SPECIFICATIONS OF THE YARNS } \\
\hline \multicolumn{1}{|c|}{ Raw material } & Yarn ype & Yarn count \\
\hline $100 \%$ Aegean Cotton & Ring & Ne 60/1 \\
\hline $100 \%$ Giza Cotton & Ring & Ne 60/1 \\
\hline $100 \%$ Supima Cotton & Ring & Ne 60/1 \\
\hline
\end{tabular}

Then knitted fabrics were produced using these yarns. The fabrics were hydrophilized by alkali treatment prior to measurement. Before testing, all yarn and fabric samples were conditioned for 24 hours under the standard atmospheric conditions $\left(20 \pm 2^{\circ} \mathrm{C}\right.$ temperatures, $65 \% \pm 5 \%$ relative humidity).

\section{Methods}

In the first stage of the work, yarn unevenness (U\%), imperfections (IPI fault) values (thin places $(-50 \%)$, thick places $(+50 \%)$ and neps $(+140 \%))$, hairiness values and breaking elongation were determined.

Yarn evenness, hairiness and imperfections (IPI fault) values were measured by USTER Tester 5 according to ISO 16549. 10 tests were done each type of yarn and the average value was taken.

Breaking elongation of the yarns was carried out according to TS 245 EN ISO 2062. $250 \mathrm{~mm}$ measuring range were used and testing speed were 250 $\mathrm{mm} /$ minute.

In the second stage of the work, these yarns were used to produce plain singe jersey fabrics. All single jersey fabrics were manufactured at the Mesdan Lab knitting machine by using the same production settings in order to eliminate the production effects. Technical properties of knitting machine were summarized in table 2 .

Table 2

TECHNICAL PROPERTIES OF KNITTING MACHINE

\begin{tabular}{|l|c|}
\hline Number of needle & 220 \\
\hline Diameter (inch) & $33 / 4$ \\
\hline Gauge & 48 \\
\hline Knitting type & Single jersey \\
\hline Yarn tension & 38 \\
\hline Production speed (turns $/ \mathrm{m})$ & 225 \\
\hline
\end{tabular}

Then these fabrics were analyzed to determine weight per square meter, thickness, bursting strength. Thickness and weight of the fabrics were measured according to the relevant standards [11-12].

Bursting strengths of the fabrics were tested according to ISO 13938-2 with 5 repetitions using JH Truburst. 
Results were evaluated by SPSS statistical program. All test results were assessed at a confidence level of at least 95\% (at most 5\% significance level).

\section{RESULTS AND DISCUSSIONS}

\section{Findings related to Uster parameters}

Table 3 shows USTER values for the yarns used in the study.

Table 3

\begin{tabular}{|c|c|c|c|}
\hline \multicolumn{4}{|c|}{ USTER VALUES OF THE YARNS } \\
\hline Material & $\begin{array}{c}100 \% \\
\text { Aegean } \\
\text { cotton }\end{array}$ & $\begin{array}{c}100 \% \\
\text { Giza } \\
\text { cotton }\end{array}$ & $\begin{array}{l}100 \% \\
\text { Supima } \\
\text { cotton }\end{array}$ \\
\hline Um (\%) & 11.44 & 10.84 & 9.93 \\
\hline CVm (\%) & 14.47 & 13.68 & 12.55 \\
\hline $\begin{array}{l}\text { Thin places }(- \\
50 \%) / 1000 \mathrm{~m}\end{array}$ & 21.6 & 5.2 & 0.8 \\
\hline $\begin{array}{l}\text { Thick places (- } \\
50 \%) / 1000 \mathrm{~m}\end{array}$ & 68.8 & 49.4 & 30.2 \\
\hline Neps $(+140 \%) / 1000 \mathrm{~m}$ & 1651 & 6496 & 529.4 \\
\hline Hairiness $(\mathrm{H})$ & 4.77 & 4.45 & 4.1 \\
\hline
\end{tabular}

When the yarn irregularity (U\%) is examined, it is seen that the yarns produced from Supima cotton fibers have the lowest value. The low CV\% means that the mass changes in the yarn are low. The yarns with a low CV\% are always preferred. The smaller the $\mathrm{CV} \%$ value, the finer the yarn. For this reason, Supima cotton is the smoothest yarn among these three types of yarns. While the Aegean cotton yarn has the highest value, the Giza cotton yarn has a value between the other two types of cotton.

It is seen that Supima cotton is superior when the number of thin and thick places are examined. Similarly, high values were observed in Aegean cotton yarns. The surfaces to be made from Supima cotton will produce a smoother appearance than the other yarns.

When the neps values are examined, the Supima cotton is seen to be advantageous. Neps, meaning small knots on the yarn surface, have a negative effect on the appearance and quality of the yarn.

When the hairiness values $(H)$ are examined, it is seen that Supima cotton has a lower value than Giza

\begin{tabular}{|c|c|c|c|c|}
\hline \multicolumn{5}{|c|}{ YARN PROPERTIES } \\
\hline Material & $\begin{array}{c}\text { Yarn } \\
\text { count } \\
\text { (Ne) }\end{array}$ & $\begin{array}{c}\text { Twist } \\
\text { coefficient }\end{array}$ & $\begin{array}{c}\text { Yarn } \\
\text { tensile } \\
\text { strength } \\
\text { (N) }\end{array}$ & $\begin{array}{c}\text { Yarn } \\
\text { breaking } \\
\text { elongation } \\
\text { (\%) }\end{array}$ \\
\hline $100 \%$ Aegean cotton & $60 / 1$ & $\alpha e=4$ & 1.3 & 3.9 \\
\hline $100 \%$ Giza cotton & $60 / 1$ & $\alpha e=4$ & 1.7 & 4.2 \\
\hline $100 \%$ Supima cotton & $60 / 1$ & $\alpha e=3.7$ & 1.9 & 4.6 \\
\hline
\end{tabular}

and Aegean Cotton. Since the Supima cotton contains extra-long fibers, the twist and the orientation of the fibers along the yarn will be good and the outgoing fiber ends will be less. This will result in less hairiness. This is a significant advantage.

Table 4 and table 5 shows the yarn and fabric properties used in the study, respectively.

Table 5

\begin{tabular}{|c|c|c|c|}
\hline \multicolumn{4}{|c|}{ FABRIC PROPERTIES } \\
\hline Material & $\begin{array}{c}\text { Weight } \\
\left(\mathbf{g} / \mathbf{m}^{\mathbf{2}}\right)\end{array}$ & $\begin{array}{c}\text { Thickness } \\
(\mathbf{m m})\end{array}$ & $\begin{array}{c}\text { Bursting } \\
\text { strength } \\
(\mathbf{k P a})\end{array}$ \\
\hline $100 \%$ Aegean cotton & 150 & 0.67 & 697 \\
\hline $100 \%$ Giza cotton & 150 & 0.63 & 813 \\
\hline $100 \%$ Supima cotton & 142 & 0.62 & 910 \\
\hline
\end{tabular}

The statistical significance of the difference between the tensile strength of the yarn and the bursting strength of the fabrics is shown in table 6 . When the tensile strength values of yarns were examined, it was determined that the strength of the yarns produced from Supima cotton was the highest and the yarns produced from Aegean cotton fibers were the lowest. Similarly, fabrics produced from Supima cotton yarns have the highest bursting strength. The difference between the tensile strength of the yarns and the bursting strength of the fabrics was found to be statistically significant (table 6).

Figures 1 and 2 show bursting strength and tensile strength.

Table 6

STATISTICAL SIGNIFICANCE LEVEL OF BURSTING STRENGTH OF FABRICS

\begin{tabular}{|c|c|c|}
\hline & Bursting strength & Tensile strength \\
\hline$p$ & $0^{*}$ & $0.015^{*}$ \\
\hline
\end{tabular}

${ }^{*} p<0.05$

Correlation analysis was carried out to determine the direction and strength of the relationship between the bursting strength of the fabrics knitted from the Supima cotton and the yarn tensile strength, the percentage of yarn extension, weight and thickness.

When table 7 is examined:

- It was determined that there was a high $(r=0.803)$, positive and significant relationship between the bursting strength of the fabric and the thickness of the fabric;

- It was determined that there was a high ( $r=0.867)$, positive and significant relationship between fabric bursting strength and fabric weight;

- It was determined that there was a high $(r=0.875)$, positive and significant relationship between the bursting 


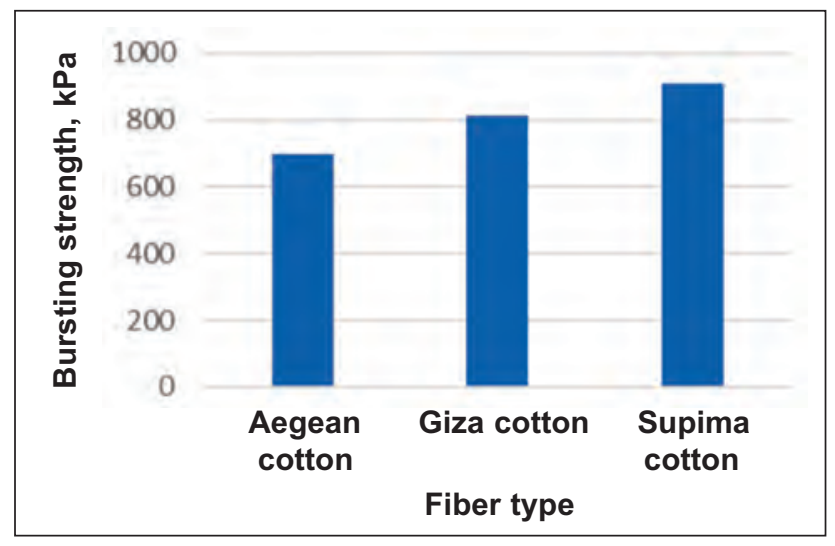

Fig. 1. Bursting strength values of fabrics

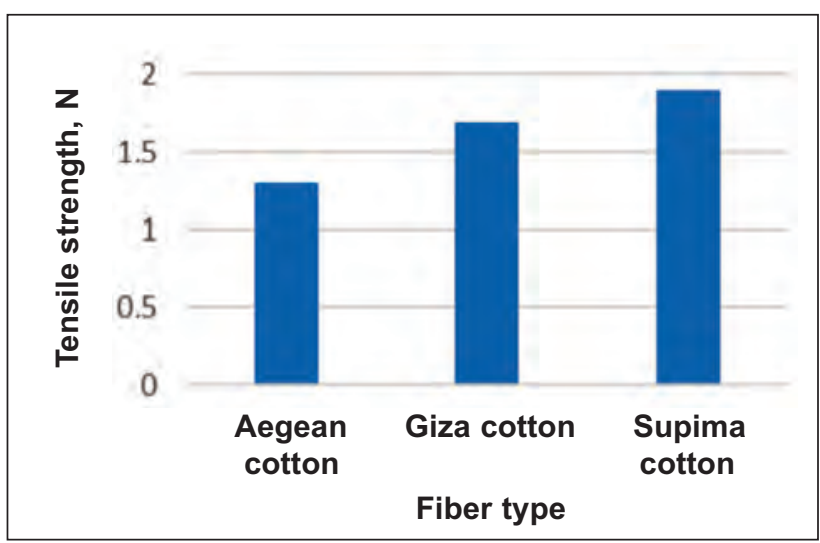

Fig. 2. Tensile strength values of yarns

\begin{tabular}{|l|c|c|c|c|c|}
\hline \multicolumn{6}{|c|}{ CORRELATION ANALYSIS OF FABRIC KNITTED FROM SUPIMA } \\
\hline \multicolumn{2}{|c|}{ Parameter } & Thickness & Weight & $\begin{array}{c}\text { Yarn tensile } \\
\text { strength }\end{array}$ & Elongation \\
\hline Bursting strength & Pearson Correlation $(r)$ & 0.803 & 0.867 & 0.93 & 0.875 \\
\hline
\end{tabular}

strength of the fabric and the percentage of yarn elongation;

- It was determined that there was a very high $(r=$ 0.93), positive and significant relationship between the bursting strength and tensile strength of the yarn.

According to the Pearson Correlation scale: $r ; 0-0.25$ very weak, $0.26-0.49$ weak, 0.50-0.69 medium, 0.70.89 high, $0.9-1.0$ very high.

Supima, Giza and Aegean Cotton rankings are formed when the bursting strength of the fabrics is ranked from high to low. Bursting strength depends on the yarn strength, yarn elongation, weight and thickness. Because of the highest tensile strength and elongation of the yarn in the knitted fabric from Supima, bursting strength of this fabric is highest. Supima fiber has extra long fiber properties. As a rule, the longer the fiber is the cotton fibers, the finer and the higher the strength. The strength of the yarn made of high strength fibers is also high.

\section{CONCLUSIONS}

Variation of fibers within wide limits in terms of fineness and length properties due to the uneven distribution of the fibers resulting from their random placement along the length of the yarn determin the number, strength, and twist properties of the yarn that change along the yarn. Irregularity in yarn is one of the most important factors affecting yarn quality in production, because the irregularities in the yarn cause the reduction of the yarn strength and the formation of thin-thick places. This causes the color unevenness in fabrics knitted with this yarn. The smoothness of the yarn depends on the raw material properties as well as on the quality of the processes that the raw material undergoes until it becomes a yarn. The yarn irregularity is expressed as a measure of how irregularly settled the fibers are in the yarn structure. The fineness and length of the fibers within the yarn structure is uniform, the yarn is so smooth and quality. When Uster results were examined, it was found that the yarn made of Supima cotton was the smoothest, low in hairiness and less neps. With these properties, the yarn breaks will be less, the image of the raw or the finished product will be more uniform. Low hairiness will also reduce the pilling tendency in the fabric.

According to the research results, the highest tensile strength of the yarns produced from Supima cotton, fabric weight and thickness are the lowest. Therefore, the bursting strength is higher than the other two materials. Supima cotton fiber has extra long fiber properties. As a rule, the longer the fiber is the cotton fibers, the finer and the higher the strength. The strength of the yarn made of high strength fibers is also high.

Considering the results obtained with the mechanical properties of the fabrics with Uster analysis applied to these yarns, it is seen that the yarns made from Supima and Giza cotton fibers in extra long fiber category have more smooth, less hairiness, contain less neps and the fabrics knitted with these yarns have high mechanical properties.

\section{ACKNOWLEDGEMENT}

This study was supported by Ege University Scientific Research Projects Coordination Unit. Project Number: 2016/BMYO/001. 


\section{REFERENCES}

[1] Erdumlu, N., Ozipek, B., Investigation of regenerated bamboo fibre and yarn characteristics, In: Fıbres \& Textiles in Eastern Europe, 2008, 16, 4 (69), 43-47

[2] Messiry, M., Abd-Ellatif, Samar, A.M., Characterization of Egyptian cotton fibres, Indian Journal of Fibre \& Textile Research, 2013, 38, 109-113

[3] Özçelik Kayseri, G., Bozdoğan, F., Hes, L., Performance properties of regenerated cellulose fiber, In: Tekstil ve Konfeksiyon, 2010, 20, 3, 208-212

[4] Demiröz Gün, A., Unal, C., Unal, B.T., Dimensional and physical properties of plain knitted fabrics made from 50/50 Bamboo/cotton blended yarns, In: Fibers and Polymers, 2008, 9, 5, 588-592

[5] Dirgar, E., The performance properties of the fabrics produced from cupro and some other regenerated cellulose fibers, In: Tekstil ve Konfeksiyon, 2017, 27, 2, 39-144

[6] Ozdemir, H., Effects of sizing and yarn structural properties on the physical properties of combed and carded cotton ring yarns, In: Industria Textila, 2018, 69, 2, http://doi.org/10.35530/IT.069.02.1329

[7] http://alpereniplik.com.tr/ege-pamugu, Date of access: 23.07.2018

[8] https://textilegence.com/supima-pamugu-hakkinda-sasirtici-5-gercek/, Date of access: 25.07.2018

[9] http://www.kirmeniplik.com/supima.html, Date of access: 23.07.2018

[10] https://tekstilsayfasi.blogspot.com/2013/01/misir-pamugu-nedir-ozellikleri.html, Date of access: 23.07.2018

[11] TS 7128 EN ISO 5084, Textiles-Determination of Thickness of Textiles and Textile Products, Turkish Standards Institution, Ankara, 1998

[12] TS 251, Determination of Mass per Unit Length and Mass per Unit Area, Turkish Standards Institution, Ankara, 1991

Authors:

\section{DIRGAR ESRA1 1 , ORAL OKSAN², OZDIL NILGUN}

${ }^{1}$ Ege University, Engineering Faculty, Textile Engineering Department Bornova 35100, Izmir, Turkey

${ }^{2}$ Ege University, Bergama Technical and Business College

Bergama 35700, Izmir, Turkey

e-mail: esra.dirgar@ege.edu.tr, oksan.kansoy@ege.edu.tr, nilgun.ozdil@ege.edu.tr

Corresponding author:

ORAL OKSAN

e-mail: oksan.kansoy@ege.edu.tr 


\title{
Blending effect of rotor spun yarn with different blending methods
}

\author{
DOI: $10.35530 / 1 T .070 .05 .1580$
}

RUI HUA YANG

QIAN QIAN DENG

\section{ABSTRACT - REZUMAT}

\section{Blending effect of rotor spun yarn with different blending methods}

Color blended rotor spun yarn mixing with different methods were spun. Three blending methods were used, one passage of drawing, three passages of drawing and rovings during multi-channel spinning. Multi-channel spinning is modified on rotor spinning machine, which is implemented by a novel mechanical system specially designed to incorporate three separate feed rollers side by side and controlled by servo motors with PLC. Using this new method, blend ratio of yarn can be controlled and realized by asynchronous drafted rovings. 37 type of color blend yarn were produced with different blending ratios. And each yarn was intercepted with 5 cross sections and a total of 185 cross-sectional images were taken. Hamilton index of different colored fibers were calculated of the each type of yarns. And sum of absolute values of Hamilton index were got to demonstrated fibers blending effect in yarns cross sections. All the Hamilton index of the yarns prepared by the three above mentioned methods were all around 5, much below 20. The results showed that regardless of blending method used, the blending effects of rotor spun yarns were all very good.

Keywords: blended yarn, cotton fiber; Hamilton transfer index, uniformity, multi-channel spinning

\section{Efectul de amestecare al firului filat cu rotor prin diferite metode de amestecare}

Firele colorate în amestec au fost filate cu rotor prin diferite metode de filare. Au fost utilizate trei metode de amestecare, printr-un pasaj de etirare, prin trei pasaje de etirare și prin semitorturi în timpul filării cu canale multiple. Filarea cu canale multiple a fost modificată pe mașina de filat cu rotor, printr-un nou sistem mecanic special conceput pentru a încorpora trei cilindri de încărcare separți, unul lângă altul și controlați de servomotoare cu PLC. Folosind această nouă metodă, raportul de amestec dintre fire poate fi controlat și realizat prin semitorturi etirate asincrone. 37 de tipuri de fire colorate în amestec au fost realizate cu diferite tipuri de raport de amestec. Fiecare fir a fost analizat prin 5 secțiuni transversale și au fost prelevate în total 185 de imagini. A fost calculat indicele Hamilton al diferitelor fibre colorate pentru fiecare tip de fir. De asemenea, suma valorilor absolute ale indicelui Hamilton a fost obținută pentru efectul de amestecare a fibrelor, în secțiunile transversale ale firelor. Indicele Hamilton total al firelor realizate prin cele trei metode menționate mai sus a fost de aproximativ \pm 5 , mult sub \pm 20 . În concluzie, indiferent de metoda folosită, efectul de amestecare al firelor filate cu rotor înregistrează rezultate foarte bune.

\section{INTRODUCTION}

The color blended yarn has the characteristics both of fashion and environmental protection. The color of the fabric woven with the color blended yarn is natural and gentle, showing a strong three-dimensional feeling and being deeply loved by consumers. The production of mixed yarns has many varieties and can have small batches, and is very popular among small and medium-sized enterprises [1-3].

Combining the new spinning technology with the production of blended yarns and exploring more suitable production processes and methods are the development directions of color spinning.

The fiber blending process of the color blended yarns includes fiber blending, sliver blending and roving blending [4-6]. Multi-colored fiber blending is generally carried out in the open and cleaning process, and the blending effect is sufficient, but the process is complicated and the requirements of the fibers are stiff. The sliver blending is made in drawing process, and parameters are set according to the blending ratio and slivers linear densities. It has the advantage of high efficiency. And the cost of equipment cleaning is high for both of fiber blending and sliver blending. The roving blending is to feed two or three rovings of different colors to the spinning frame with different feeding speed separately according to the color blending ratio, achieving the desired color [3]. It shows spinning flexibility and products variety of the blended yarns. However, there is not any published work to reveal the fiber blending effect of sliver blending and roving blending.

In this study, cotton fibers of three colors (red, yellow and blue) were used as the raw material, and color blended rotor spun yarns were produced by the two above-mentioned methods respectively. The blending uniformity of the fibers in the yarn was analyzed.

\section{FIBER BLENDING METHODS}

\section{Sliver blending}

Sliver blending is realized by blending a plurality of colored slivers in the drawing process according to a pre-set color blending ratio. It can be used by one 
passage drawing or three passages, depending on the requirement of fiber blending effect. In this study, the blending effects of one passage drawing and three are both analyzed.

\section{Roving blending}

In this research, roving blending is made by threechannel rotor spinning process which is shown in figure 1. It is implemented by a novel mechanical system specially designed to incorporate three separate feed rollers side by side and controlled by servo motors with PLC. Using this new method, three different slivers can be fed and controlled individually (feeding speeds can be the same or different). So that various color blended yarns can be produced by controlling the ratio of three basic colored rovings (red, yellow and blue) via changing the feed speed of each roving, and also different materials blended yarns could be produced.

As observed, the three different colored fiber rovings are fed to the opening roller through their corresponding feeding rollers. Then the continuous and tight fiber strips are divided into sparse streams by splitting to achieve separation and orientation of the fibers. Under the acceleration airflow in the fiber transport channel, the streams are further separated into a single fiber to enter the rotor. Such single fibers are collected in the groove at the bottom of the rotor with the centrifugal force of the high-speed rotor. Accordingly, through stripping, opening, cleaning, carding, and transfer of the carding roller, fiber bundles are separated into single fibers. Afterwards, multiple slivers asynchronously feed into the rotor spun unit. Multi layers of condensed fibers are combined as a bundle and twisted to form a yarn by the blocking action of the false twisting disc, which is led by a mother yarn. Subsequently, the yarns are wound onto a tube by winding roller. With such a spinning process, the objective of flexibility, high efficiency, and high yield are realized.

\section{EXPERIMENTS}

Red, yellow and blue colored cotton rovings and slivers were used as the raw materials. Rovings linear densities of red, yellow and blue are 4.34, 4.4 and $4.26(\mathrm{~g} / 10 \mathrm{~m})$ respectively. And linear densities of slivers are 45.28, 43, 42.64 (g/10 m). Three blending methods were used, one passage of drawing, three passages of drawing and roving. Both of two and three component colored yarns were spun with linear density of 44.85 tex and twist factor of 400 with different blending ratios. The blending ratios of sliver blending and roving blending were showed in tables 1-2.

\begin{tabular}{|c|c|c|c|c|c|c|c|c|c|c|c|c|}
\hline \multicolumn{13}{|c|}{ BLENDING RATIO OF TWO-COMPONENT YARN BLENDED BY ONE PASSAGE OF DRAWING } \\
\hline \multicolumn{4}{|c|}{ One passage of drawing } & \multicolumn{4}{|c|}{ Three passage of drawing } & \multicolumn{5}{|c|}{ Roving during spinning process } \\
\hline \multirow[t]{2}{*}{ No. } & \multirow{2}{*}{$\begin{array}{c}\text { Sliver } \\
\text { number }\end{array}$} & \multicolumn{2}{|c|}{$\begin{array}{l}\text { Blending } \\
\text { ratios } \\
(\%)\end{array}$} & \multirow[t]{2}{*}{ No. } & \multirow{2}{*}{$\begin{array}{c}\begin{array}{c}\text { Sliver } \\
\text { number }\end{array} \\
\begin{array}{c}\text { Yellow: } \\
\text { Blue }\end{array}\end{array}$} & \multicolumn{2}{|c|}{$\begin{array}{l}\text { Blending } \\
\text { ratios } \\
(\%)\end{array}$} & \multirow[t]{2}{*}{ No. } & \multicolumn{2}{|c|}{$\begin{array}{c}\text { Blending } \\
\text { ratios } \\
(\%)\end{array}$} & \multicolumn{2}{|c|}{$\begin{array}{c}\text { Feed speed } \\
\text { of rovings } \\
\text { (m/min) }\end{array}$} \\
\hline & & Yellow & Blue & & & Yellow & Blue & & Yellow & Blue & Yellow & Blue \\
\hline 1 & $1: 5$ & 16.8 & 83.2 & 6 & $1: 5$ & 16.8 & 83.2 & 9 & 16.8 & 83.2 & 0.51 & 1.41 \\
\hline 2 & $2: 4$ & 33.5 & 66.5 & 7 & $2: 4$ & 33.5 & 66.5 & 10 & 33.5 & 66.5 & 1.03 & 2.10 \\
\hline 3 & $3: 3$ & 50.2 & 49.8 & 8 & $3: 3$ & 50.2 & 49.8 & 11 & 50.2 & 49.8 & 1.54 & 1.57 \\
\hline 4 & $4: 2$ & 66.8 & 33.2 & & & $\theta$ & & 12 & 66.9 & 33.1 & 2.04 & 1.05 \\
\hline 5 & $5: 1$ & 83.4 & 16.6 & & & 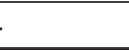 & & 13 & 83.5 & 16.5 & 2.55 & 0.52 \\
\hline
\end{tabular}

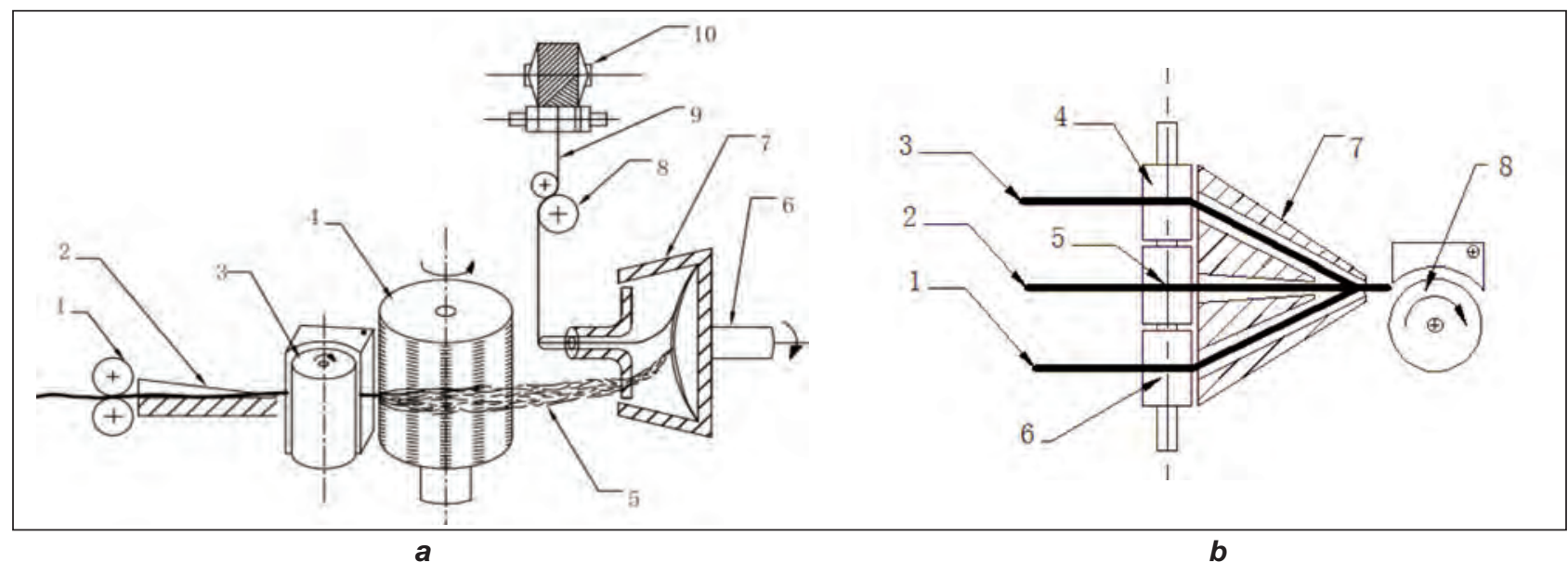

Fig. 1. Three channel rotor spun feed mechanism (a: 1 - combined feed rollers, 2 - collector, 3 - main roller, 4 - carding roller, 5 - fiber transport channel, 6 - bearing, 7 - rotor, 8 - guide roller, 9 - yarn, 10 - bobbin; $b: 1,2,3$ - slivers, 4, 5, 6 - combined feed rollers, 7 - collector, 8 - main roller) 


\begin{tabular}{|c|c|c|c|c|c|c|c|c|c|c|c|c|c|c|c|c|}
\hline \multicolumn{17}{|c|}{ BLENDING RATIO OF THREE-COMPONENT YARN BLENDED BY ONE PASSAGE OF DRAWING } \\
\hline \multicolumn{5}{|c|}{ One passage of drawing } & \multicolumn{5}{|c|}{ Three passage of drawing } & \multicolumn{7}{|c|}{ Roving during spinning process } \\
\hline \multirow{2}{*}{ No. } & \multirow{2}{*}{\begin{tabular}{|c|}
$\begin{array}{c}\text { Sliver } \\
\text { number }\end{array}$ \\
Red: \\
Yellow: \\
Blue
\end{tabular}} & \multicolumn{3}{|c|}{$\begin{array}{c}\text { Blending ratios } \\
(\%)\end{array}$} & \multirow{2}{*}{ No. } & \multirow{2}{*}{$\begin{array}{c}\begin{array}{c}\text { Sliver } \\
\text { number }\end{array} \\
\text { Red: } \\
\text { Yellow: } \\
\text { Blue }\end{array}$} & \multicolumn{3}{|c|}{$\begin{array}{l}\text { Blending ratios } \\
(\%)\end{array}$} & \multirow{2}{*}{ No. } & \multicolumn{3}{|c|}{$\begin{array}{l}\text { Blending ratios } \\
(\%)\end{array}$} & \multicolumn{3}{|c|}{$\begin{array}{c}\text { Feed speed of rov- } \\
\text { ings } \\
\text { (m/min) }\end{array}$} \\
\hline & & Red & Yellow & Blue & & & Red & Yellow & Blue & & Red & Yellow & Blue & Red & Yellow & Blue \\
\hline 14 & 1:1:4 & 16.9 & 16.4 & 66.7 & 24 & $1: 1: 4$ & 16.9 & 16.4 & 66.7 & 28 & 16.9 & 16.4 & 66.7 & 0.52 & 0.50 & 2.11 \\
\hline 15 & $1: 2: 3$ & 16.9 & 32.9 & 50.2 & 25 & $1: 2: 3$ & 16.9 & 32.9 & 50.2 & 29 & 17.0 & 32.8 & 50.2 & 0.53 & 1.00 & 1.59 \\
\hline 16 & 1:3:2 & 17.0 & 49.4 & 33.6 & 26 & 1:3:2 & 17.0 & 49.4 & 33.6 & 30 & 33.7 & 16.4 & 49.9 & 0.53 & 1.51 & 1.06 \\
\hline 17 & 1:4:1 & 17.1 & 66.1 & 16.8 & 27 & 1:4:1 & 17.1 & 66.1 & 16.8 & 31 & 33.8 & 32.8 & 33.4 & 0.53 & 2.02 & 0.53 \\
\hline 18 & 2:1:3 & 33.8 & 16.3 & 49.9 & & & - & & & 32 & 34.0 & 49.3 & 16.7 & 1.05 & 0.50 & 1.58 \\
\hline 19 & $2: 2: 2$ & 33.8 & 32.8 & 33.4 & & & - & & & 33 & 50.5 & 16.3 & 33.2 & 1.05 & 1.00 & 1.05 \\
\hline 20 & $2: 3 ; 1$ & 33.9 & 49.4 & 16.7 & & & - & & & 34 & 50.6 & 32.7 & 16.7 & 1.05 & 1.51 & 0.53 \\
\hline 21 & $3: 1: 2$ & 50.5 & 16.3 & 33.2 & & & - & & & 35 & 67.9 & 16.1 & 16.0 & 1.57 & 0.50 & 1.05 \\
\hline 22 & $3: 2: 1$ & 50.6 & 32.7 & 16.7 & & & - & & & 36 & 50.6 & 32.7 & 16.7 & 1.57 & 1.00 & 0.53 \\
\hline 23 & $4: 1: 1$ & 67.9 & 16.1 & 16.0 & & & - & & & 37 & 58.4 & 28.0 & 13.6 & 2.11 & 1.00 & 0.50 \\
\hline
\end{tabular}

\section{RESULTS AND DISCUSSION}

The Hamilton fiber migration index is a parameter to calculate and analyze the distribution of component fibers in a blended yarn [7-9]. It is based on certain first moments of the given component about the center of the yarn cross-section. Here, the maximum possible zoned fiber counts are taken on suitable number of cross-sections which expresses the actual migration of the component that could have occurred in the yarn. While $\pm 100 \%$ migration index value represents complete separation of the components but a zero value represents random distribution. The positive and negative signs denote outward and inward migration respectively [10-12].

Each yarn was intercepted with 5 cross sections and 185 cross-sectional images of 37 yarns were used to calculate the Hamilton index of the fibers in each cross section. And representative samples of each yarn were pointed out in figures $2-7$. The calculated mean valueswere showed in table 3.

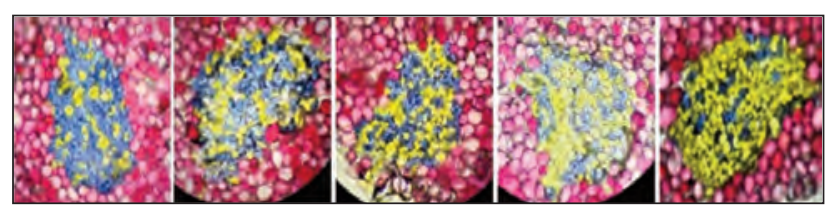

Fig. 2. Two-component yarn blended by one passage of drawing (1-5)

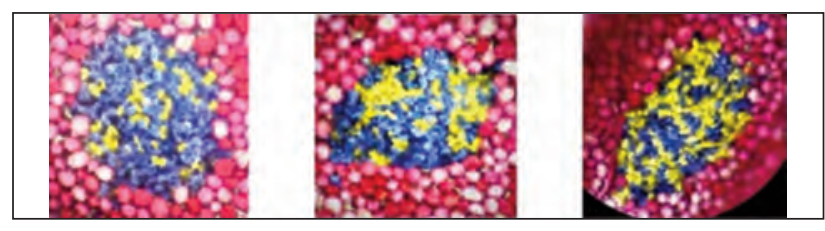

Fig. 3. Two-component yarn blended by three passage of drawing (6-7)

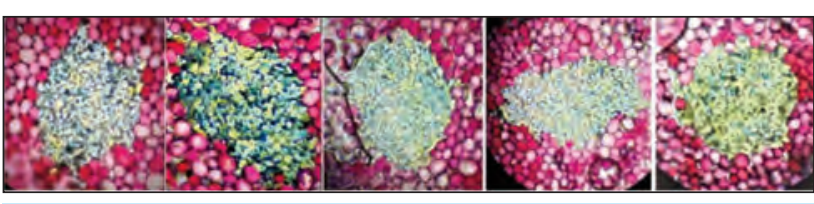

Fig. 4. Two-component yarn blended by rovings (9-13)

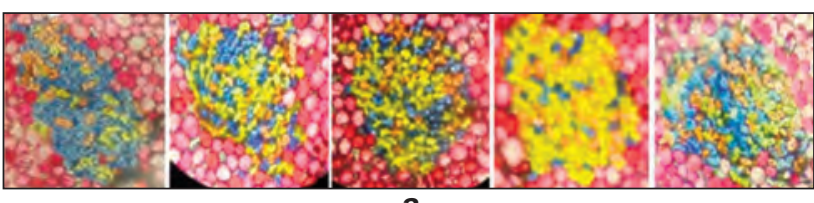

a

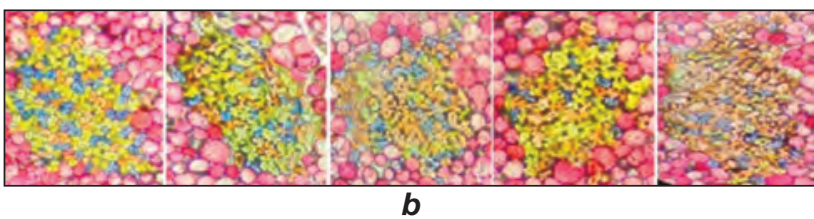

Fig. 5. Three-component yarn blended by one passage of drawing: $a-(14-18) ; b-(19-23)$

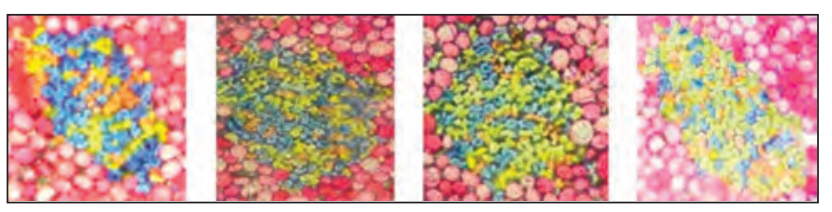

Fig. 6. Three-component yarn blended by three passages of drawing (24-27)

When one passage of sliver blending is used, the sum of the absolute values of the Hamilton index for each colored fiber was $1 \%$ and $3 \%$ for two-component and three-component yarns respectively.

For three passages, the sum of the absolute values of the Hamilton index was $2.34 \%$ and $5.03 \%$ for the two above mentioned yarns. 


\begin{tabular}{|c|c|c|c|c|c|c|c|}
\hline \multicolumn{8}{|c|}{ HAMILTON INDEX OF FIBERS } \\
\hline $\begin{array}{c}\text { Two } \\
\text { components }\end{array}$ & $\begin{array}{c}\text { One } \\
\text { passage } \\
(\%)\end{array}$ & $\begin{array}{c}\text { Three } \\
\text { passages } \\
(\%)\end{array}$ & $\begin{array}{c}\text { Rovings } \\
(\%)\end{array}$ & $\begin{array}{c}\text { Three } \\
\text { components }\end{array}$ & $\begin{array}{c}\text { One } \\
\text { passage } \\
(\%)\end{array}$ & $\begin{array}{c}\text { Three } \\
\text { passages } \\
(\%)\end{array}$ & $\begin{array}{c}\text { Rovings } \\
(\%)\end{array}$ \\
\hline Yellow fibers & 0.50 & 1.17 & -1.20 & Yellow fibers & -1.04 & 0.91 & 3.79 \\
\hline \multirow{2}{*}{ Blue fibers } & \multirow{2}{*}{-0.50} & \multirow{2}{*}{-1.17} & \multirow{2}{*}{1.20} & Blue fibers & 1.41 & 0.56 & 2.10 \\
\hline & & & & Red fibers & 0.55 & -3.56 & -1.29 \\
\hline $\begin{array}{c}\text { Sum of } \\
\text { absolute value }\end{array}$ & 1 & 2.34 & 2.4 & $\begin{array}{c}\text { Sum of } \\
\text { absolute value }\end{array}$ & 3 & 5.03 & 7.18 \\
\hline
\end{tabular}
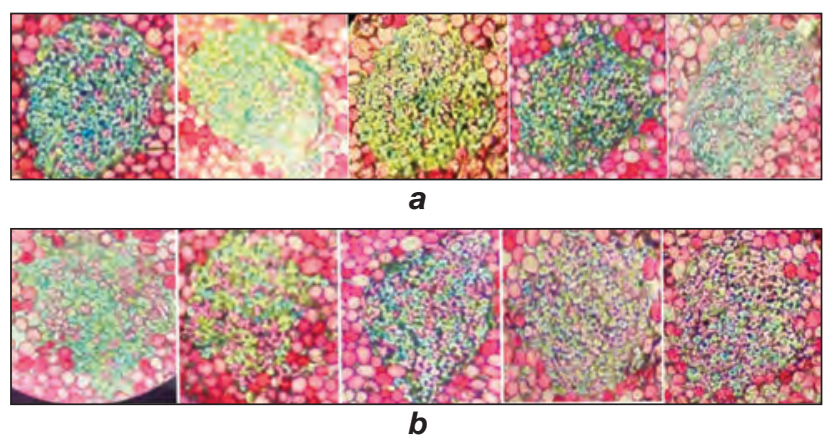

Fig. 7. Three-component yarn blended by rovings: $a-(28-32) ; b-(33-37)$

When the blending method is by roving, the sum of the absolute values of the Hamilton index was $2.4 \%$ and $7.18 \%$ for two-component and three-component yarns respectively.

It was figured out that the blending effect of one passage is the best, three passage second, and roving third. Compared with one passages, the blending effect of three passages was reduced because of the deviation of fiber movement distance during the drawing process.

During the rotor spun process, fiber strand was combed and mixed by the opening roller. Under the centrifugal force in the rotor, passing by transport channel, fibers were then mixed and condensed as a bundle in the rotor groove. Then the yarn was formed after being twisted. So there were three chances to mix fibers. That also means rotor spun yarn with sliver blending had been blended not only during the spinning process, but also during the drawing process. That's the reason why blending effect of blended rotor yarn with sliver blending was better than that of roving blending.
But all the Hamilton index values of three blending types were under $20 \%$, which demonstrated that the blending effects of the rotor spun yarns all met the blending uniformity requirements. Therefore, fibers can be very well blended during the rotor spun process, not matter which blending method was used.

\section{CONCLUSION}

Three methods of fibers blending, one passage drawing, three passages and roving were used to mix fibers. Two components and three components color blended rotor yarns were spun. Fiber blending effects of yarns were studied by Hamilton index. The results showed that the Hamilton index of fibers in yarn cross sections obtained by the three blending methods were all within the range of $\pm 5 \%$, less than $\pm 20 \%$, indicating that the blending method has no obvious influence on the uniformity of the rotor-spun blended yarn. And rotor spun is a good method to blend fibers during spinning process. The most suitable fiber blended method can be selected according to the actual situation to maximize the benefit of rotor spun yarns.

\section{ACKNOWLEDGEMENT}

This work was supported by Natural Science Foundation of Jiangsu Province of China No. BK20181350, the National Natural Science Foundation of China (No. 51403085), the National Key R\&D Program of China (2017YFB0309200), the Innovation fund project of Cooperation among Industries, Universities \& Research Institutes of Jiangsu Province (BY2016022-29), the Fundamental Research Funds for the Central Universities No. JUSRP51631A and Priority Academic Program Development of Jiangsu Higher Education Institutions (PAPD).

\section{REFERENCES}

[1] Ahmad, Z., Eldeeb, M., Iqbal, S., et al., Effect of yarn structure on cover factor in woven fabrics, In: Industria Textila, 2018, 69, 3, 197-201, http://doi.org/10.35530/IT.069.03.1416

[2] Seyedi, R., Najar, S.S., Hoseinpour, A.R., Investigation of fiber migration in rotor-jet spun yarn, In: Journal of the Textile Institute, 2017, 108, 10, 1794-1799

[3] Yang, R.H., Xue,Y., Gao, W.D., Airflow characteristics of different groove type during rotor spinning process, In: Industria Textila, 2017, 68, 3, 165-169, http://doi.org/10.35530/IT.068.03.1367 
[4] Karthik, T., Murugan, R., Sakthivel, J.C., Comfort properties and dyeing behaviour of cotton/milkweed blended rotor yarn fabrics, In: Indian Journal of Fibre \& Textile Research, 2017, 42, 1, 25-30

[5] Yang, R.H., Xue, Y., Gao, W.D., Structure and performance of color blended rotor spun yarn produced by a novel frame with asynchronous feed rollers, In: Textile Research Journal, 1-13, http://doi.org/10.1177/0040517517748493

[6] Lshtiaque, S.M., Study of cross section of yarn, In: Textile Asia, 1993, 11, 36-38

[7] Hearle, J.W.S., Goswami, P., Migration of fibers in yarns, part VII: further experiments on continuous filament yarns, In: Textile Research Journal,1968, 38, 8, 790-802

[8] Hamilton, J.B., Cooper, D.N.E., The radical distribution of fibers in blended yarns. Part II - Factors affecting the preferential migration of components in blended, In: Journal of Textile Institute Transactions, 1958, 49, 12, 687-698

[9] Sinha, S.K., Kumar, P., Ghosh, S., A study on the packing density of structurally modified ring spun yarn, In: Fibers \& Polymer, 2016, 17, 11, 1898-1907

[10] Lam, N.Y.K., Zhang, M., Guo, H., Effect of fiber length and blending method on the tensile properties of ring spun chitosan-cotton blend yarns, In: Textile Research Journal, 2017, 7, 2, 244-257

[11] Bechir, W., Mohamed, B.H., Bechir, A., Industrial cotton waste: recycling, reclaimed fiber behavior and quality prediction of its blend, In: Tekstilve Konfeksiyon, 2018, 28, 1, 14-20

[12] Uyanik, S., Baykal, P.D., Effects of fiber types and blend ratios on Murata Vortex yarn properties, In: Journal of the Textile Institute, 2018, 109, 8, 1099-1109

Authors:

RUI HUA YANG, QIAN QIAN DENG, CHUN PING XIE, WEI DONG GAO

Key Laboratory of Science \& Technology for Eco-Textiles, Education Ministry, Jiangnan University, 1800 Lihu Avenue, Wuxi, Jiangsu Province, 214122, P.R. China

Corresponding author:

RUI HUA YANG

e-mail: yangrh@jiangnan.edu.cn 


\section{Effect of silane KH550 on interface of basalt fibers (BFs)/poly (lactic acid) (PLA) composites}

DOI: 10.35530/IT.070.05.1596

SHU-QIANG LIU

YAO ZHANG

JUAN-JUAN YU

JIE ZHANG

GAI-HONG WU

XIAO-LONG YIN

PENG WANG

FU LI

MING-FANG LIU

MAN ZHANG

ABSTRACT - REZUMAT

Effect of silane KH550 on interface of basalt fibers (BFs)/poly (lactic acid) (PLA) composites

The basalt fibers/poly (lactic acid) composites, as a kind of green environment friendly materials, were prepared by vacuum perfusion method. The effect of silane coupling agent KH550 on the interface of BFs/PLA composites was analyzed. We observed the microstructure of the surface of BFs treated by silane KH550 and the interface of the composites, explored the chemical reaction among silane KH550, BFs and PLA. The silane KH550 succeeded in linking BFs and PLA and enhanced the interfacial bonding strength between BFs and PLA matrix. The crystalline properties of KH550-treated BFs/PLA composites were better than untreated BFs/PLA composites. The mechanical test suggested the silane KH550 had good effect on strengthening BFs/PLA composites.

Keywords: basalt fibers, poly (lactic acid), silane KH550, microstructure, interfaces

\section{Efectul silanului KH550 asupra interfeței compozitelor din fibre de bazalt (BF)/acid (poli) lactic (PLA)}

Compozitele din fibre de bazalt/acid (poli) lactic, ca material ecologic, au fost realizate prin metoda infuziei în vacuum. S-a analizat efectul agentului de cuplare silan KH550 asupra interfeței compozitelor BF/PLA. Au fost analizate microstructura suprafeței BF-urilor tratate cu silan KH550 și interfața compozitelor și a fost studiată reacția chimică dintre silan KH550, BF și PLA. Silanul KH550 a reușit să lege BF și PLA și a îmbunătățit rezistența legăturii interfeței dintre matricea BF și PLA. Proprietățile de cristalinitate ale compozitelor BF/ PLA tratate cu KH550 au fost mai bune decât cele ale compozitelor BF/PLA netratate. În urma testătii fizico-mecanice, s-a observat că silanul KH550 a condus la îmbunătăţirea rezistenței compozitelor BF/PLA.

Cuvinte-cheie: fibre de bazalt, acid (poli) lactic, silan KH550, microstructură, interfeţe

\section{INTRODUCTION}

Basalt fibers (BFs), a kind of silicate fiber, are made of natural volcanic exhalation-basalt. The broken basalt is added into a furnace and melted at $1450^{\circ} \mathrm{C}-1500^{\circ} \mathrm{C}$, and then leaked from a platinumrhodium alloy wire drawing plate to form continuous filament [1-5]. BFs are eco-friendly fibers, which attract lots of attention from researchers and constructors because of their strong tensile strength, high elastic modulus, high abrasion strength, good temperature-resistance, excellent heat and sound insulation, good chemical stability and so on [6-9]. Therefore, BFs are called as a green industrial material in $21^{\text {st }}$ century.

In order to enhance the polymer matrix, plastics and cements, BFs are often used as reinforcements [1014]. The composites, which is made of biomaterialPLA as matrix and BFs as reinforcement, can meet the general requirements of light weight, high strength [15-17]. Furthermore, it possesses a large variety of excellent comprehensive properties, such as degradable, non-toxic, harmless, environmentally friendly and so on. Thus, the BFs/PLA composites are widely used in the fields of medical devices, automobile shell, leisure sports goods, wind power fan leaf and others [18-20].

However, the compatibility between BFs and PLA matrix is very poor, which leads to poor interface performance and decreased mechanical properties for the BFs/PLA composites [21-24]. Therefore, the interface between BFs and PLA is need to be modified.

Kurniawan et al. evaluated the effects of atmospheric pressure glow discharge plasma polymerization on $\mathrm{BF}$ to the properties of BFs/PLA composite [25]. Ying et al. reported that treatment of BFs with silane coupling agent to improve mechanical properties of composites [26].

Previous studies focused on the effect of interfacial treatment on the properties of composites, without further study on the specific process and mechanism of silane coupling agent acting on the interface [2729]. In this paper, in order to enhance the adhesion and durability of fibers-matrix interfaces of BFs/PLA composites, the silane coupling agent of $\mathrm{KH} 550$ was applied to treat the surface of BFs, then the BFs and PLA were chemically linked by KH550. While the influence of silane $\mathrm{KH} 550$ on tensile fracture ability of 
composite is studied, the interface structure and interfacial bonding principle are analyzed. It provides more ideas for the latter to solve the interfacial problem of composites.

\section{EXPERIMENTAL WORK}

\section{Material and methods}

The samples of $200 \mathrm{~mm} \times 200 \mathrm{~mm}$ basalt fabric (fiber-unidirectional cloth, plain texture), were soaked in $5 \%$ alkali solution $(100 \mathrm{~mL})$ for 30 minutes, and then were washed for at least 3 times and dried in a vacuum oven at $80^{\circ} \mathrm{C}$. After that, the treated basalt fabric was immersed in $100 \mathrm{~mL}$ alcoholysis solution of KH550 with different concentrations for $1 \mathrm{~h}$ at room temperature. $50 \mathrm{~g}$ dried PLA powder (levorotatory, 51000 viscosity-average molecular weight), were added in $100 \mathrm{~mL}$ dichloromethane, and then they were magnetically stirred until completely dissolved together. PLA resin (viscosity, $258 \mathrm{mPa} \cdot \mathrm{s}$ ) was poured into five layers of unidirectional basalt fabrics by vacuum perfusion method. And the vacuum remained at $-0.01 \mathrm{mPa}$. Then the BFs/PLA composites were dried in a vacuum oven at $80^{\circ} \mathrm{C}$ for $2 \mathrm{~h}$.

The surface morphology of BFs and composites were inspected by scanning electron microscopy (JEM2100F). FTIR spectra of BFs, PLA and composites were recorded with a FT-IR (TENSOR27). Every spectrum was recorded from 400 to $4000 \mathrm{~cm}^{-1}$ using $4 \mathrm{~cm}^{-1}$ of resolution. The crystalline structure of composites and PLA were analyzed by an X-ray diffractometer (JSM-6700F) with a scanning range of 10$60^{\circ}$. The tensile tests of composites were carried out on a universal testing machine with a spline size of $250 \times 25 \times 2 \mathrm{~mm}$ and a tensile rate of $2 \mathrm{~mm} / \mathrm{min}$, and conducted in accordance to the standards GB/T 1447-2005.

\section{RESULTS AND DISCUSSION}

\section{SEM analysis}

The surface morphologies of untreated BFs, treated BFs, untreated-BFs/PLA composites and treatedBFs/PLA composites were depicted in figure 1, a-d. Figure 1, a shows that the surface of untreated BFs is not damaged, and very smooth. In contrast, the surface of treated BFs (figure 1,b) produces new substances that make BFs rougher and forma dense protective film on the surface of BFs. Moreover, the adhesion between fibers causes BFs to be more closely entangled. Additionally, the surface microstructure of untreated-BFs/PLA composites are showed in figure 1, c. Fibers are connected by a matrix, but the interface between fibers and matrix is very clear. Once the composites are damaged by force, some cracks will appear at the weak interface junction firstly. There are not any obvious interface-separations between BFs and PLA matrix, as shown in figure 1, $d$. The PLA resin completely infiltrates the BFs bundle, and be integrated with BFs tightly. These indicate that the KH550 can well link BFs with PLA matrix, and
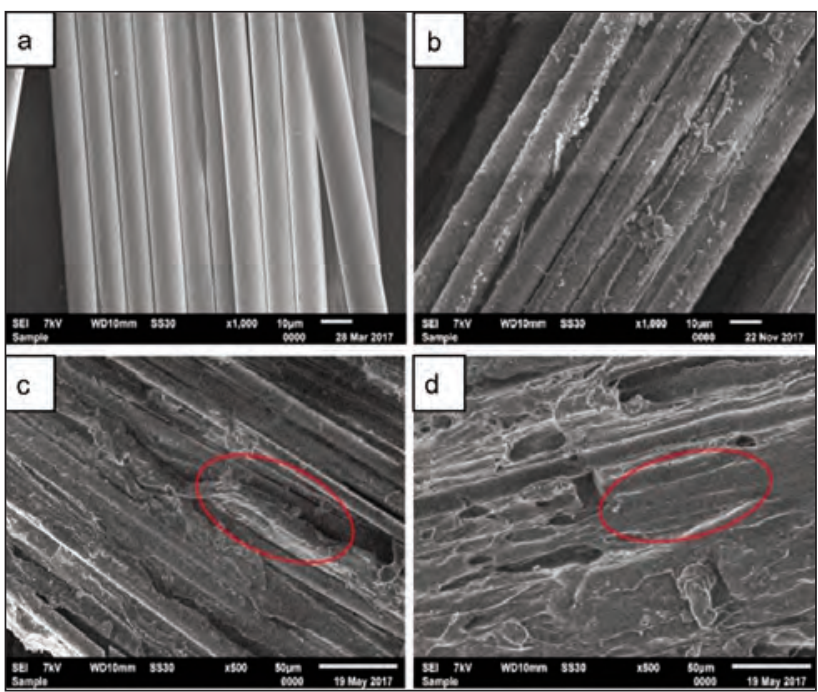

Fig. 1. SEM images of BFs and composites: $a$ - untreated BFs; $b$ - treated BFs;

$c$ - untreated-BFs/PLA composites;

$d$ - treated-BFs/PLA composites

then improve the compatibility between BFs and PLA matrix.

\section{FTIR analysis}

In figure 2, the strong absorption peak of untreated BFs at $849 \mathrm{~cm}^{-1}$ is $\mathrm{Si}-\mathrm{OH}$ stretching vibration, and the absorption peak at nearly $1633 \mathrm{~cm}^{-1}$ is the residual $-\mathrm{OH}$ stretching vibration. The spectra of treatedBFs shows that a characteristic peak at $1029 \mathrm{~cm}^{-1}$ due to $\mathrm{Si}-\mathrm{O}-\mathrm{C}$ stretching vibration of organosilicon compound or Si-O-Si asymmetric stretching vibration, and that some weak peaks at $1300-1100 \mathrm{~cm}^{-1}$ are assigned to the $\mathrm{C}-\mathrm{N}$ stretching vibration of primary amine. These new chemical functional groups are formed on the surface of treated-BFs which suggest that the KH550 exists on the surface of BFs. The characteristic absorption peaks of PLA are the vibration peaks of $\mathrm{C}=\mathrm{O}$ bond at $1754 \mathrm{~cm}^{-1}$, the bending peak of $-\mathrm{CH}_{3}$ group at $1380 \mathrm{~cm}^{-1}$ and the vibration

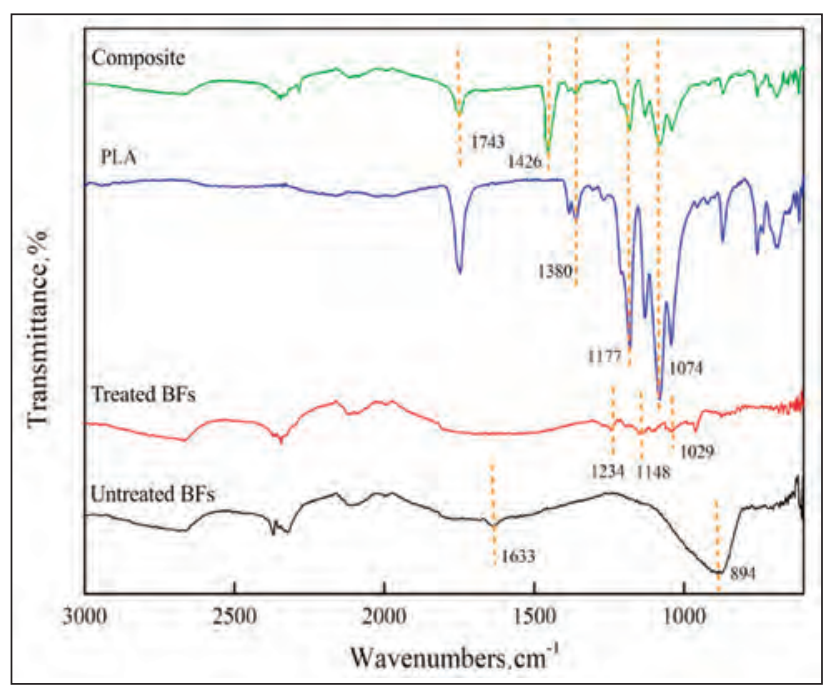

Fig. 2. FTIR spectra of untreated BFs, treated BFs, PLA and composite 


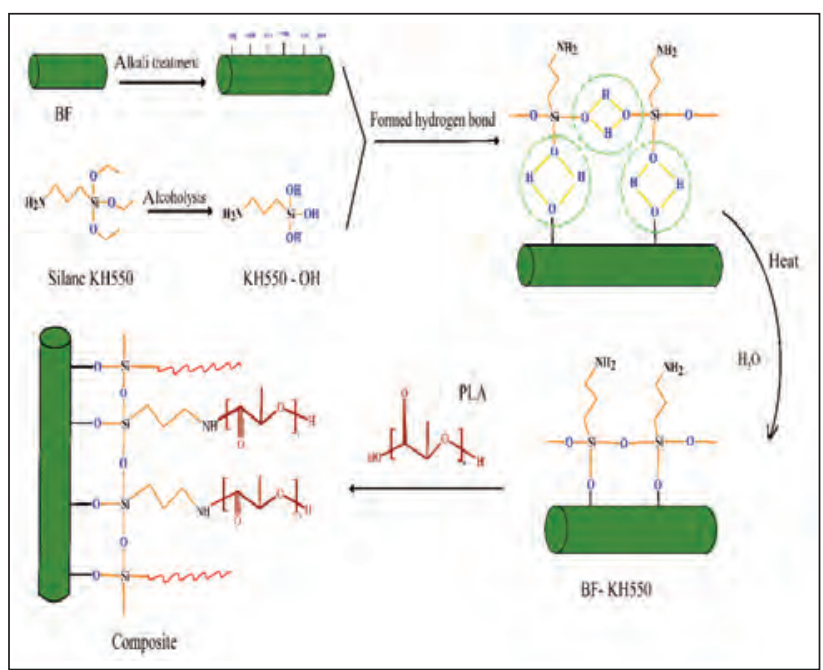

Fig. 3. The chemical reaction between PLA, BFsand silane $\mathrm{KH} 550$

peaks of $\mathrm{C}-\mathrm{O}$ bond at $1117 \mathrm{~cm}^{-1}$, and $1074 \mathrm{~cm}^{-1}$. From the spectra of BFs/PLA composites, it can be clearly seen that the absorption peaks of BFs/PLA composites contain the characteristic absorption peaks of PLA and that of treated BFs. Moreover, the absorption peak of $\mathrm{C}-\mathrm{N}$ stretching vibration of amide is appeared at $1426 \mathrm{~cm}^{-1}$.

Thus, according to the changes of chemical bonds and functional groups, the chemical reactions among PLA, BFs and silane KH550 can be deduced, as shown in figure 3.

\section{XRD analysis}

Furthermore, the crystal structure of untreatedBFs/PLA composites, treated-BFs/PLA composites and PLA were examined by XRD patterns (figure 4). Based on the XRD results, the PLA displays two peaks at diffraction angles of $16.86^{\circ}$ and $18.89^{\circ}$, which are related to relatively stable lattice planes of 110 and 203 respectively. The composites have some similar diffraction peaks, but the position of diffraction peaks moves to the right, which may be affected by grain size, lattice distortion or internal

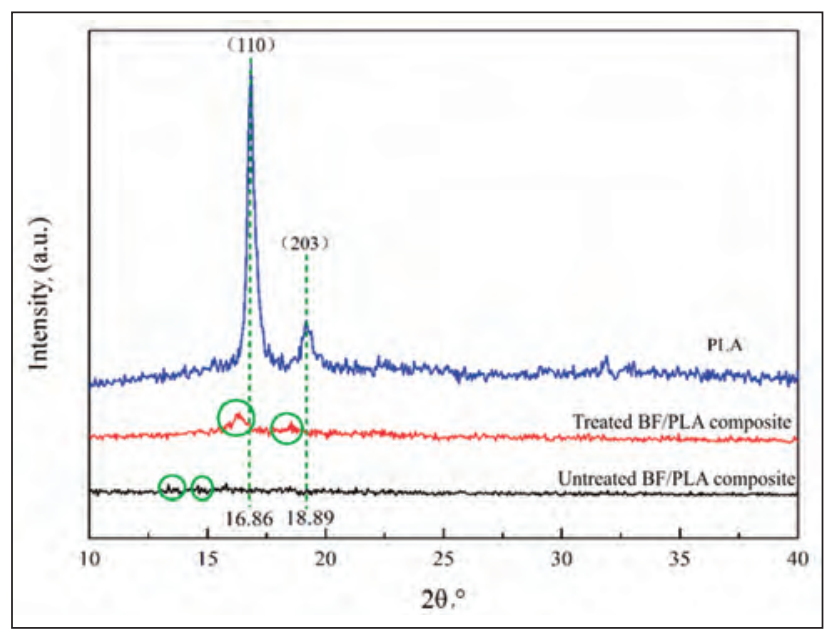

Fig. 4. XRD patterns of untreated BFs/PLA composite, treated BFs/PLA composite and PLA stress. Moreover, the intensity of diffraction peaks becomes weaker, revealing that the added-BFs reduce the crystal grains and crystallinity of PLA matrix. However, the characteristic peak of untreated-BFs/PLA composites is extremely small and even disappeared, which demonstrates that this composite becomes a disordered amorphous state. The results that the crystallinity of treated-BFs/PLA composite is better than that of untreated-BFs/PLA composite, and the $\mathrm{KH} 550$, used to treat BFs, can improve the crystallinity of composites.

In addition, if the BFs are treated by different concentrations of $\mathrm{KH} 550$, the tensile strength of composites will be improved, as shown in figure 5 .

\section{Meachnical properties}

In addition, if the BFs are treated by different concentrations of $\mathrm{KH} 550$, the tensile strength of composites will be improved, as shown in figure 5 . The interface treatment effect was the best when the concentration of $\mathrm{KH} 550$ was $3 \%$ wt. The fracture failure of BFs/PLA composite mainly occurs in the interface area. The KH550 can link BFs with PLA matrix tightly, and formed a silane network layer which perform a function of micromechanical meshing, thus the interfacial bonding strength is improved. Furthermore, the KH550 between BFs and PLA matrix can promote the transfer of stress, so that the PLA matrix can bear more loading. At the same time, the KH550 can reinforce the PLA matrix directly, and enhance the bonding strength between the inner interlayer and adjacent composite layer, after that, the mechanical properties of composites are increased.

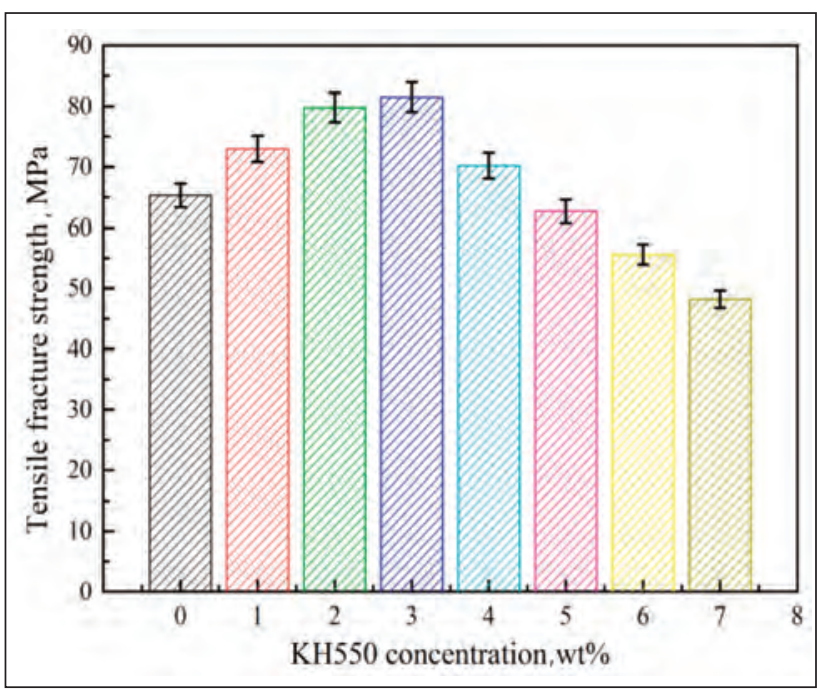

Fig. 5. Effect of KH550 concentration on tensile fracture strength of BFs/PLA composite

\section{CONCLUSIONS}

The composites, which were made of PLA as matrix and $\mathrm{KH} 550$-treated BFs as reinforcement, were prepared by the vacuum perfusion method. The mechanical properties of composites had been significantly improved. The results of SEM analysis indicated that 
the KH550 built a "bridge" between BFs and PLA matrix successfully, which combined BFs and PLA matrix tightly. The FTIR revealed that one end of KH550 was connected with the hydroxyl groups of BFs, and the other end of $\mathrm{KH} 550$ was connected with the carboxyl groups of PLA. The XRD analysis indicated that the crystalline properties of $\mathrm{KH} 550$-treated BFs/PLA composites were better than untreatedBFs/PLA composites.

\section{ACKNOWLEDGEMENTS}

This work was supported by the MOE (Ministry of Education in China) Project of Humanities and Social Sciences (18YJC760051), 2017 Shanxi Philosophy and
Social Science Project (201702), Program for the Philosophy and Social Sciences Research of Higher Learning Institutions of Shanxi (PSSR) (201803060), the Shanxi University Students Innovation and Entrepreneurship Training Program Project (2018099), the Students Innovation and Entrepreneurship Training Program Project of Taiyuan University of Technology (18049), the Scientific and Technological Innovation Programs of Higher Education Institutions in Shanxi, China (2015125) and the Youth Foundation of Taiyuan University of Technology, China (2015QN042). And Shuqiang Liu would also like to acknowledge financial support through International Visit Program of Taiyuan University of Technology.

\section{REFERENCES}

[1] Fiore, V., Scalici, T., Di Bella, G., Valenza, A., A review on basalt fibre and its composites, In: Compos. Part B Eng., 2015, 74, 74-94

[2] Chen, X., Zhang, Y., Huo, H., Wu, Z., Study of high tensile strength of natural continuous basalt fibers, In: J. Nat. Fibers, 2018, 1-9

[3] Gutnikov, S.I., Malakho, A.P., Lazoryak, B.I., Loginov, V.S., Influence of alumina on the properties of continuous basalt fibers, In: Russ. J. Inorg. Chem., 2009, 54, 2, 191-196

[4] Jamshaid, H., Mishra, R., A green material from rock: basalt fiber a review, In: J. Text. Inst. Proc. Abstr., 2016, 107, 7, 923-937

[5] Živković, I., Fragassa, C., Pavlović, A., Brugo,T., Influence of moisture absorption on the impact properties of flax, basalt and hybrid flax/basalt fiber reinforced green composites, In: Compos. Part B Eng., 2017, 111, 148-164

[6] Rickard, W., Vickers, D.a.L., Van Riessen, A., Performance of fibre reinforced, low density metakaolin geopolymers under simulated fibre conditions, In: Appl. Clay Sci., 2013, 73, 73, 71-77

[7] Bauer, F., Kempf, M., Weiland, F., Middendorf, P., Structure-property relationships of basalt fibers for high performance applications, In: Compos. Part B Eng., 2018, 145, 3, 121-128

[8] Czigany, T., Trends in fiber reinforcements - the future belongs to basalt fiber, In: Express Polym. Lett., 2007,1, 2, 59

[9] Jain, N., Singh, V.K., Chauhan, S., Review on effect of chemical, thermal, additive treatment on mechanical properties of basalt fiber and their composites, In: J. Mech. Behav. Mater., 2018, 26, 5-6, 205-211

[10] Branston, J., Das, S., Kenno, S.Y., Taylor, C., Influence of basalt fibres on free and restrained plastic shrinkage, In: Cem. Concr. Compos., 2016, 74, 182-190

[11] Zeng, J.J., Guo, Y.C., Gao, W.Y., Chen, W.P., Li, L.J., Stress-strain behavior of circular concrete columns partially wrapped with FRP strips, In: Compos. Struct., 2018, 50-54

[12] Duic, J., Kenno, S., Das, S., Performance of concrete beams reinforced with basalt fibre composite rebar, In: Constr. Build. Mater., 2018, 176, 470-481

[13] Gurunathan, T., Mohanty, S., Nayak, S.K., A review of the recent developments in biocomposites based on natural fibres and their application perspectives, In: Compos. Part A, 2015, 77, 1-25

[14] Öztürk, B., Arslan, F., Öztürk, S., Hot wear properties of ceramic and basalt fiber reinforced hybrid friction materials, In: Tribol. Int., 2007, 40, 1, 37-48

[15] Tábi, T., Égerházi, A.Z., Tamás, P., Czigány, T., Kovács, J. G., Investigation of injection moulded poly(lactic acid) reinforced with long basalt fibres, In: Compos. Part A, Appl. Sci. Manuf., 2014, 64, 21, 99-106

[16] Liu, T., Yu, F., Yu, X., Zhao, X., Lu, A., Basalt fiber reinforced and elastomer toughened polylactide composites: Mechanical properties, rheology, crystallization, and morphology, In: J. Appl. Polym. Sci., 2012, 125, 2, 1292-1301

[17] Liu, Q., Shaw, M.T., Parnas, R.S., Mcdonnell, A., Investigation of basalt fiber composite mechanical properties for applications in transportation, In: Polym. Compos., 2010, 27, 1, 41-48

[18] Yang, W., et al., Carbon nanotube reinforced polylactide/basalt fiber composites containing aluminium hypophosphite: thermal degradation, flame retardancy and mechanical properties, In: Rsc Adv., 2015, 5, 128, 105869-105879

[19] Kuzmin, K.L., Timoshkin, I.A., Gutnikov, S.I., Zhukovskaya, E.S., Lipatov, Y.V., Lazoryak, B.I., Effect of silane/nanosilica on the mechanical properties of basalt fiber reinforced epoxy composites, In: Compos. Interfaces, 2017, 24, $1,13-34$

[20] Samper, M.D., Petrucci, R., Sánchez $\square$ Nacher, L., Balart, R., Kenny, J.M., Effect of silane coupling agents on basalt fiber-epoxidized vegetable oil matrix composite materials analyzed by the single fiber fragmentation technique, In: Polym. Compos., 2015, 36, 7, 1205-1212

[21] Wang, G.J., Liu, Y.W., Guo, Y.J., Zhang, Z.X., Xu, M.X., Yang, Z.X., Surface modification and characterizations of basalt fibers with non-thermal plasma, In: Surf. Coat. Technol., 2007, 201, 15, 6565-6568 
[22] Wang, Z., Chen, N., Jiang, J., Tensile behavior of textile reinforced flexible composites with notch, In: Ind. Textilă, $2011,62,1,24-29$

[23] Girgin, Z.C., Yıldıım, M.T., Usability of basalt fibres in fibre reinforced cement composites, In: Mater. Struct., 2016, 49, 8, 3309-3319

[24] Lv, L.H., Liu, G.B., Zhou, D., Process and mechanical properties of basalt fiber/polylactic acid composites, In: Appl. Mech. Mater., 2012, 193-194, 329-332

[25] Kurniawan, D., Kim, B.S., Lee, H.Y., Lim, J.Y., Atmospheric pressure glow discharge plasma polymerization for surface treatment on sized basalt fiber/polylactic acid composites, In: Compos. Part B, 2012, 43, 3, 1010-1014

[26] Ying, Z., Wu, D., Zhang, M., Qiu, Y., Polylactide/basalt fiber composites with tailorable mechanical properties: Effect of surface treatment of fibers and annealing, In: Compos. Struct., 2017, 176, 1020-1027

[27] Wang, Y., Yu, W.D., Wang, F.M., Effects of process variables on physical characteristics of tri-component elasticconductive composite yarns (t-ECCYs) using a modified ring frame, In: Industria Textila, 2018, 69, 1, 17-23, http://doi.org/10.35530/IT.069.01.1397

[28] Chen, S., Wang, X.Q., Characterization of the impact and post impact (CAI) properties of 3D-structure composites, In: Industria Textila, 2017, 68, 6, 415-420, http://doi.org/10.35530/IT.068.06.1570

[29] Liu, S.Q., Wu, G.H., Xiao, Y.C., Guo, H.X., Shao, F.J., Crystallization behavior and mechanical properties of poly(lactic acid) complex fiber toughened by carbon nanotube nanocapsules, In: Text. Res. J., 2018, 88, 1616-1627

Authors:

SHU-QIANG LIUa, JUAN-JUAN YUa, GAI-HONG WU, PENG WANG, MING-FANG LIU, YAO ZHANG, JIE ZHANG, XIAO-LONG YIN, FU LI, MAN ZHANG

Taiyuan University of Technology, College of Textile Engineering, 030021, Taiyuan, China

No. 209, University street, Yuci district, Jinzhong city, Shanxi province, China

aThese authors contributed equally to this work and should be considered co-first authors

Corresponding authors:

SHU-QIANG LIU

e-mail: liushuqiang8866@126.com

GAI-HONG WU

e-mail:gaigai2003@126.com 


\title{
Influence of crosslinking agent on the effectiveness of flame retardant treatment for cotton fabric
}

\author{
DOI: $10.35530 / 1 T .070 .05 .1610$
}

\section{ABSTRACT - REZUMAT}

\section{Influence of crosslinking agent on the effectiveness of flame retardant treatment for cotton fabric}

In this study, the commercial organophosphorus compound Pyrovatex CP New was used as a flame retardant for cotton fabric. Citric acid and a modified dihydroxy ethylene urea (DHEU) labelled Knittex FFRC were used as crosslinking to increase the flame-retardant laundering durability of treated cotton fabric. There have been some studies showing that Chitosan has the potential to improve flame retardancy and laundering durability of flame retardant treated cotton fabric. Thus, Chitosan, which has the molecular weight of 2.600 (water soluble) and the deacetylation degree of approximately $75 \%$, is added to finishing solution for flame retardant treatment of cotton fabric. The padding-drying-curing method was used in this study. After treatment, all samples were examined to determine the chemical absorption level. The $45^{\circ}$ flammability test characteristics and LOI value of untreated and treated samples after different number of washing cycle were determined to assess the flame retardancy of the treated fabric and its laundering durability. In addition, to assess the impact of this treatment on the mechanical strength and ecology of the fabric, the tensile strength and free formaldehyde content of the treated fabric were also evaluated.

Keywords: flame retardant, crosslinking agent, cotton fabric, Pyrovatex CP New

Influența agentului de reticulare asupra eficienței tratamentului de ignifugare pentru țesătura din bumbac

În acest studiu, compusul comercial de organofosfor Pyrovatex CP New a fost utilizat ca agent de ignifugare pentru țesăturile din bumbac. Acidul citric și dihidroxietilen ureea modificată (DHEU) etichetată Knittex FFRC au fost utilizaţi ca agenți de reticulare, pentru a crește rezistenţa la spălare a țesăturii de bumbac tratată cu agent de ignifugare. Există studii care arată că chitosanul are potențialul de a îmbunătăți rezistența la flacără și durabilitatea spălării țesăturii de bumbac tratate ignifug. Astfel, chitosanul, care are greutatea moleculară de 2,600 (solubil în apă) și gradul de deacetilare de aproximativ $75 \%$, se adaugă soluției de finisare pentru tratamentul ignifug al țesăturii de bumbac. Metoda de fulardare-uscare-reticulare a fost utilizată în acest studiu. După tratament, toate probele au fost examinate pentru a determina nivelul de absorbție chimică. Caracteristicile testului de inflamabilitate la $45^{\circ}$ și valoarea LOI a probelor netratate și tratate, după un număr diferit de cicluri de spălare au fost determinate pentru a evalua rezistența la flacără a țesăturii tratate și durabilitatea acesteia la spălare. În plus, pentru a evalua impactul acestui tratament asupra rezistenței mecanice și a caracteristicilor ecologice ale țesăturii, a fost de asemenea evaluată rezistența la tracțiune și conținutul de formaldehidă din țesătura tratată.

Cuvinte-cheie: agent de ignifugare, agent de reticulare, țesătură din bumbac, Pyrovatex CP New

\section{INTRODUCTION}

Cotton fabric is an important textile widely used to produce apparels, home furnishings, and various industrial products due to its characteristics of softness, breathability, and moisture absorbability [1]. However, the vital drawback of cotton fabric, i.e., flammability, limits its use. It ignites easily and is frequently implicated in fire. Cotton cellulose undergoes degradation on ignition, forming highly combustible volatile compounds mainly laevoglucose with the propagation of fire causing injuries and fatalities in fire accidents [1].

Flame retardant fabrics are needed for a variety of uses such as home furnishing and decorations (curtains, drapes, upholstery, bedding, mattresses, wall coverings and trimmings etc.); uniforms for fire-fighters; apparels and garments (sleepwear, nightwear, children's wear, loose garments, sarees, shawls, kitchen wear, etc., where there are chances of accidental contact with flame) etc. [2].

Flame retardants are applied to textiles to make them noninflammable or self-extinguishing [3]. Flame retardants with chemical and/or physical action retard or block the process of burning in particular phases of burning so that they stop the inflow of heat to the polymer, block the access of oxygen, increase the generation of non-flammable gases and the content of char residue; or reduce the generation of flammable ones, acting in the gaseous and condensed phases. These mechanisms often cannot be clearly separated [4].

Many studies have attempted to impart flame retardancy in cotton by grafting flame retardant (FR) groups, coating with flame retardant layers, or directly adding fire retardants to polymer materials [5]. The most common classes of flame retardants are brominated, phosphorus, nitrogen, chlorinated, and 
inorganic [3]. Halogen-containing FR systems have come under scrutiny due to health and environmental concerns and have recently been restricted in many communities. Recent developments of FR molecules have focused on organophosphorus compounds [6]. Phosphorus-based FR has become a popular alternative to halogen compounds because of their environmentally friendly by-products and their low toxicity. Also, their low production of smoke in fire furthers their appeal. It is a highly effective flame retardant for cellulose and cellulose derivatives. These compounds promote dehydration and char formation [7]. One of the most commercially successful agents is $\mathrm{N}$-methylol dimethylphosphonpropionamide, known under the trade name of Pyrovatex CP New (PR). Some studies have shown the effect of PR on flame retardancy for cotton fabrics [8-12].

One important task is to create a covalent bond between the PR and the fabric to ensure the durable flame-retardant cotton fabric. In studies [8, 11], the flame retardant laundering durability of cotton fabrics treated with PR agents can be improved by resin application. Organophosphorus agents are combined with melamine resins and an acid as catalyst such as phosphorus acid. The purpose of the melamine resin is to provide nitrogen in order to enhance the flame retarding performance of the treated fabric through synergism with phosphorus [8]. However, it shows the drawback of high formaldehyde release when used with methylated melamine based crosslinking, a known carcinogenic compound [9]. Another drawback is the significant mechanical strength loss of the treated fabric due to curing at a high temperature and in the highly acidic condition of $\mathrm{pH} 1-2$ with the presence of phosphoric acid [11].

For this reason, some studies [8-10], tried to use polycarboxylic acids instead of melamine resin particularly, the 1,2,3,4-butane tetracarboxylic acid (BTCA) and citric acid (CA) have attracted significant research interest as formaldehyde-free finishing agents. These acids can form an ester cross-link structure with cellulose. By forming two or more ester bonds with cellulose macromolecules, these can produce a crosslinking fiber structure possessing a high level of crease recovery $[9,13]$. However, BTCA has 4 carboxyl groups and CA has 3 carboxyl groups, if another $-\mathrm{COOH}$ group of them can form an ester bond with $\mathrm{PR}$, it would produce a cross linkage between cellulose and PR. Carboxylic acids can esterify cotton fibers in the presence of sodium hypophosphite as a catalyst [13]. However, there was also the mechanical strength loss of treated fabric, that was due to the high temperatures and high acidic condition of curing although this loss was less than the use of phosphoric acid [10].

For the aforementioned reasons, DHEU (dihydroxy ethylene urea) and its modified compounds are used as crosslinking agent in finishing for cotton. With DHEU, PR can react with cellulosic substances by crosslinking with ether bonds. In comparison with the polycarboxylic acids, DHEU has only two hydroxyl groups to make cross linkage between hydroxyl groups of the cellulose and PR, while BTCA has four carboxylic groups and CA has three groups to make cross linkage between PR and cellulose. Thus, in principle, the cross linkage between cellulose and PR is easier to form with CA or BTCA than with DHEU. However, the mechanical strength of cotton fabric can be reduced in the esterification reaction. Recently, based on DHEU, Huntsman has introduced a new crosslinking labelled Knittex FFRC that can make cross linkages to cellulose without the help of the catalyst. It was used as crosslinking in softening and antifungal finishing of cotton fabric [14-15]. These studies show that Knittex FFRC was a good cross-linker between cotton and finishing agents. Could it be used as cross-linker between cotton and PR? The overall efficiency of the Knittex FFRC and CA should be evaluated according to the flame-retardant laundering durability as well as the mechanical strength loss of the treated fabric.

In order to clarify this issue, in this study, cotton fabric was treated to be flame retardant by $P R$ and two crosslinking options: citric acid and Knittex FFRC. The objective of the work is to select the most effective crosslinking by creating a durable bond between cellulose and PR. Furthermore, it had less effect on mechanical strength as well as on the ecological properties of the fabric. In addition to the above two experiments, a third experiment was carried out in which CA was used as crosslinking and Chitosan was added into the finishing solution with the aim to increase the flame retardant efficiency of the fabric. Chitosan (CTS) is an amino polysaccharide obtained by the alkaline deacetylation process of chitin, a naturally occurring polymeric material. In this study, CTS acts as a natural nitrogen source that synergizes with phosphorus to increase the fire efficiency $[16,17]$. Finally, the ecological, physical, and thermal properties of treated cotton fabrics were investigated to choose the most effective crosslinking.

\section{EXPERIMENTAL}

\section{Materials}

The $100 \%$ cotton fabric was supplied by Hanoi Dyeing Joint Stock Company, Viet Nam. The fabrics were desized, scoured, bleached and mercerized. Their technical characteristics are showed in table 1.

Table 1

TECHNICAL CHARACTERISTICS OF THE FABRIC

\begin{tabular}{|c|c|c|c|c|c|}
\hline \multirow{2}{*}{$\begin{array}{c}\text { Construc- } \\
\text { tion }\end{array}$} & \multicolumn{2}{|c|}{$\begin{array}{c}\text { Linear } \\
\text { density of } \\
\text { yarn (tex) }\end{array}$} & \multicolumn{2}{|c|}{$\begin{array}{c}\text { Fabric } \\
\text { density } \\
\text { (yarn/10 } \mathbf{~ c m} \text { ) }\end{array}$} & \begin{tabular}{c} 
Surface \\
mass of \\
fabric \\
\cline { 2 - 5 }
\end{tabular} \\
\cline { 2 - 5 } & warp & weft & warp & weft & wart \\
\hline $\begin{array}{c}\text { Twill } \\
\text { weaves 2/1 }\end{array}$ & 17.24 & 35.71 & 560 & 230 & 190 \\
\hline
\end{tabular}

Pyrovatex CP New (PR), Knittex FFRC (K), Invadine PBN were supplied by Huntsman. Pyrovatex CP New (PR) is a $\mathrm{N}$-methylol dimethylphosphonpropionamide, 
in this study, it was used as flame retardant agent. Knittex FFRC is a modified dihydroxy ethylene urea, it was used as crosslinking and Invadine PBN as tenside agents.

Citric Acid (CA) was used as another crosslinking to compare the effect on flame retardant laundering durability to Knittex FFRC agent. Sodium hypophosphite (SHP) was used as catalyst for the case of crosslinking agent CA, which was supplied by Xilong Scientific.

Chitosan 187.000 Da, with the deacetylation degrees of about $75 \%$ was purchased from the Chitosan Vietnam One member Limited Company. This Chitosan was irradiated at Department of Radiation Technology, Hanoi Irradiation Center in order to have chitosan with MW 2.600 (water soluble) and $\mathrm{DD} \approx 75 \%$.

The chemical formulas of the main agents are showed in table 2.

Table 2

CHEMICAL FORMULAS OF THE MAIN AGENTS

\begin{tabular}{|c|c|}
\hline Agent & Chemical formula \\
\hline Pyrovatex CP New & 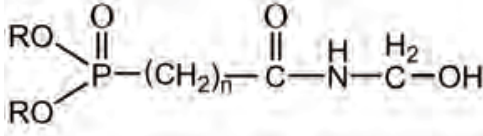 \\
\hline Citric Acid & $\mathrm{OH}-\left.\right|_{\mathrm{CH}_{2}-\mathrm{COOH}} ^{\mathrm{C}}-\mathrm{COOH}$ \\
\hline Chitosan & $\mathrm{HO}-\mathrm{CH}_{2}-\mathrm{R}_{1}-\mathrm{NH}_{2}$ \\
\hline $\begin{array}{l}\text { Dihydroxy ethylene } \\
\text { urea }\end{array}$ & $\mathrm{HO}_{\mathrm{H}}^{\mathrm{I}} \stackrel{\mathrm{H}_{\mathrm{H}}^{\mathrm{O}}}{\mathrm{C}}-\mathrm{OH}$ \\
\hline
\end{tabular}

\section{Method}

\section{Flame retardant treatment for cotton fabric}

One bath, pad-dry-cure technique was used in this study for flame retardant treatment. First, the fabric was impregnated in finishing solution, then padded, dried and cured.

Finishing solution formulations:

The three aforementioned formulations were used in this study, they were named as FS1, FS2, FS3. The details of these formulations are presented in table 3 Flame retardant treatment process:

All three experiments were carried out under the same conditions: The fabric samples $35 \times 35 \mathrm{~cm}$ were impregnated with finishing solution (the bath formulations are shown in table 3 ), then padded with a wet pick-up of approximately $80 \%$ by padder SDL D394A. The padded samples were dried at $110^{\circ} \mathrm{C}$ for $5 \mathrm{~min}$ utes. After that these samples were cured at $180^{\circ} \mathrm{C}$ for 2 minutes. The Stenter SDL D398 was used for

\begin{tabular}{|c|c|c|c|c|c|c|}
\hline \multicolumn{7}{|c|}{ FINISHING SOLUTION FORMULATIONS } \\
\hline $\begin{array}{c}\text { The } \\
\text { bath }\end{array}$ & $\begin{array}{c}\text { PR } \\
(\%)\end{array}$ & $\begin{array}{c}\text { K } \\
(\%)\end{array}$ & $\begin{array}{c}\text { CA } \\
(\%)\end{array}$ & $\begin{array}{c}\text { SHP } \\
(\%)\end{array}$ & $\begin{array}{c}\text { Tenside } \\
(\%)\end{array}$ & $\begin{array}{c}\text { CTS } \\
(\%)\end{array}$ \\
\hline FS1 & 40 & - & 7 & 6.5 & 0.5 & - \\
\hline FS2 & 40 & - & 7 & 6.5 & 0.5 & 1 \\
\hline FS3 & 40 & 7 & - & - & 0.5 & - \\
\hline
\end{tabular}

*\% weight of fabric

drying and curing steps. Next, the samples were washed under running water for 5 minutes and then dried in the stenter at $110^{\circ} \mathrm{C}$ for 3 minutes. The treated samples were stored in the polyethylene bags and in the standard laboratory conditions for 24 hours before any further analysis.

\section{Treated samples washing}

To determine the flame retardant durability of the fabric after treatment, the treated samples were washed in accordance with ISO-6330 standard clause 6A [19] but without added detergent. The Electrolux EW $1290 \mathrm{~W}$ front load washing machine was used. Washed samples were stored after 5, 10, 15, 20 and 30 wash cycles to test the flammability of samples.

\section{Assessment of treated fabric's properties}

Determination of real uptake of recipe chemicals (add-on\%) on fabric

The real uptake of recipe chemicals (add-on\%) on the fabric after the aforementioned treatment was calculated using Eq. (1) and the results are presented in table 4.

$$
\text { Add-on }(\%)=\frac{W_{F}-W_{0}}{W_{0}} \times 100
$$

In Eq. (1), $W_{F}$ is the standard condition weight of the treated sample, and $W_{0}-$ the standard condition weight of the untreated sample.

The test was repeated six times for each finishing solution. The final result is an average of the 6 tests Flammability test

The $45^{\circ}$ flammability test method (ASTM D 1230 94) [20] was used for evaluating the flammability of the untreated and finished fabrics. The test was carried out at Chemical textile LAB of Hanoi University of Science and Technology.

LOI (limiting oxygen index) test

The LOI values of the control and finished cotton fabrics were measured in accordance with the ASTM D 2863-97 standard method [21] at Laboratory of Polymer Center of Hanoi University of Science and Technology (HUST).

Tensile strength test

Tensile strength of the fabric was determined according to ISO 13934-1:2013 standard method [22] at Testing Center of Textile - Leather Materials of HUST Formaldehyde content measurement

The free formaldehyde content of FR finished specimens was tested with reference to the guidelines 
given in EN ISO 14184-1:1998 standard [23] at zero wash and after 01 washing cycle at Chemical textile LAB of HUST.

\section{RESULTS AND DISCUSSION}

Reaction mechanisms of the chemical agents

In the first experiment (FS1): in this experiment, the effective ester crosslinking by CA between PR and cellulose illustrated by a reaction mechanism given in Scheme 1. However, the ester crosslinking by CA could be also produced between two cellulosic molecules, which could enhance crease recovery of fabric. Besides, it could be also created between two PR molecules, because of not linked to cellulose so it could be removed in washing.

In the second experiment (FS2), there are many cases that could be happened. The ester crosslinking by CA may be between PR and cellulose (Scheme 1).
CA also could react with chitosan by esterification reaction (with $\mathrm{OH}$ group of chitosan) or by amidation reaction (with amine group of chitosan). Thus, the crosslinking by CA could be produced between PR and chitosan, also between chitosan and cellulose and so on.

In the third experiment (FS3): the effective ether crosslinking by DHEU between $\mathrm{PR}$ and cellulose illustrated by a reaction mechanism is given in case 1 of Scheme 2. Besides, DHEU may be reacted only with cellulose (case 2 ) or only with PR (case 3 ).

\section{The FR uptake of finished fabric}

The real uptake of recipe chemicals (add-on\%) on the fabrics treated with three finishing solutions are presented in table 4.

The chemicals add-on $\%$ on the sample treated with FS3 (using Knittex FFRC) is only $10.7 \%$ while it is

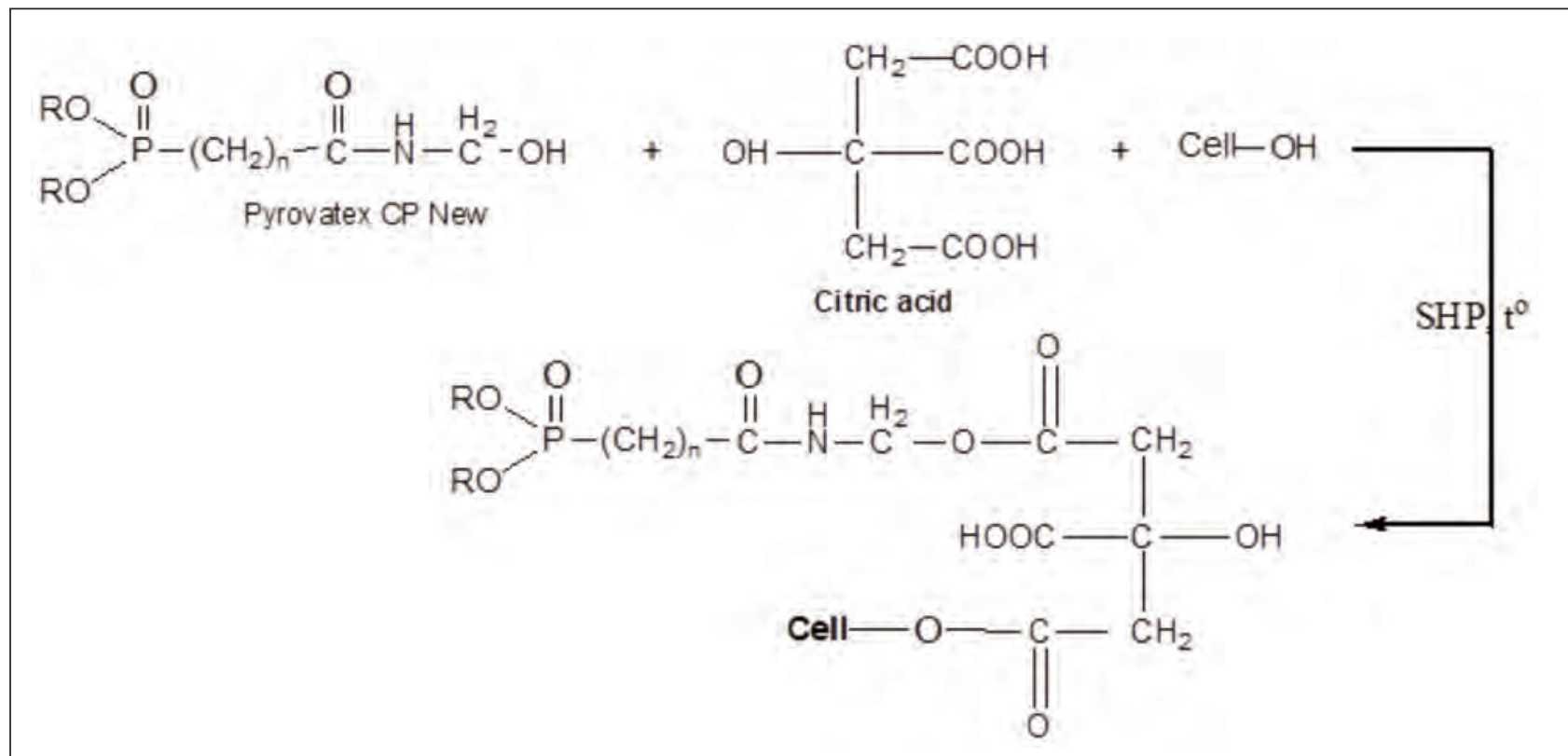

Scheme 1: Crosslinking mechanism of CA with Pyrovatex CP New and cellulose [10]

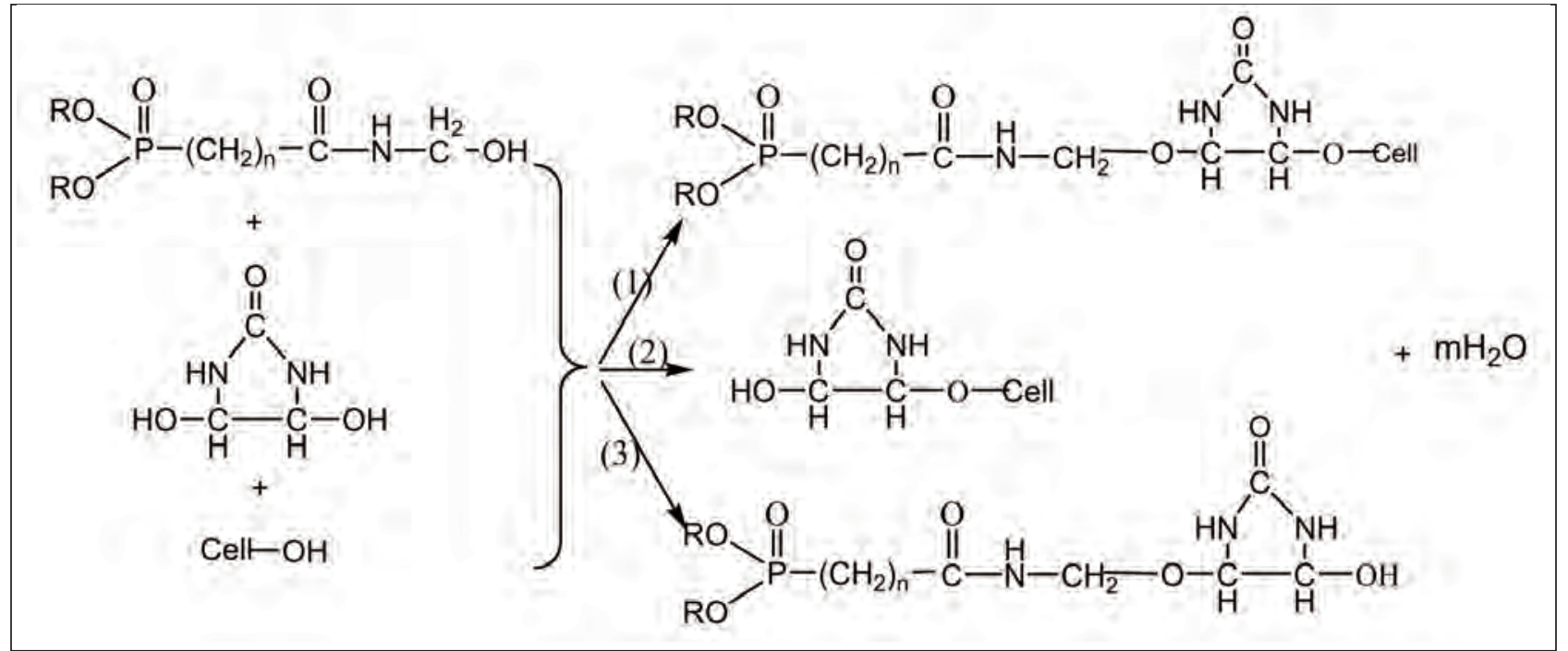

Scheme 2: Crosslinking mechanism of DHEU with Pyrovatex CP New and cellulose [18] 
Table 4

THE REAL FR UPTAKE (ADD-ON\%) ON TREATED FABRICS

\begin{tabular}{|c|c|c|c|}
\hline \multirow{2}{*}{$\begin{array}{c}\mathbf{N}^{\circ} \text { of test } \\
\text { for each FS }\end{array}$} & \multicolumn{3}{|c|}{ Add-on of treated sample (\%) } \\
\cline { 2 - 4 } & FS1 & FS2 & FS3 \\
\hline 1 & 17.35 & 19.08 & 10.19 \\
\hline 2 & 17.90 & 15.55 & 9.86 \\
\hline 3 & 17.81 & 18.64 & 11.94 \\
\hline 4 & 18.53 & 18.00 & 11.06 \\
\hline 5 & 17.54 & 18.01 & 10.93 \\
\hline 6 & 17.68 & 14.43 & 10.07 \\
\hline Average of Add-on (\%) & 17.80 & 17.28 & 10.67 \\
\hline Standard deviation & 0.18 & 0.38 & 0.26 \\
\hline
\end{tabular}

$17.8 \%$ and $17.28 \%$ for FS1 and FS2 respectively, indicating the excellent bonding between PR and cellulose structure in the presence of CA crosslinking. This phenomenon might occur because CA has 3 $\mathrm{COOH}$ groups for linkage while Knittex FFRC (DHEU) has only $2-\mathrm{OH}$ groups as said on. However, the add-on decreases $0.52 \%$ for FS2 in comparison with FS1. It is possible that the addition of chitosan into the solution without any supplement of CA is the cause of this phenomenon. Could this amount of add-on be beneficial to the flammability behavior of treated fabrics? This will be clarified in the test of flammability of fabrics.

\section{Effect of crosslinking on the flammability of the finished fabric}

To evaluate the flame retardant properties of the treated and laundered fabrics, $45^{\circ}$ flammability characteristics of the samples were investigated. The results of these tests are presented in table 5 and figure 1.

Table 5 and figure 1 show that the control sample burned vigorously after direct exposure to the ignition source. The ignition time was only 3 seconds. After removing the combustion source, the sample continued to burn until it had burned out. The cotton fabric almost completely burned out without any remains (figure 1,a). Furthermore, there was 9 seconds of afterglow. In contrast to the untreated sample, all treated samples and treated samples after different washing cycles showed good behaviors against the $45^{\circ}$ flammability test: the ignition times were 9 seconds. After removing the combustion source, the samples were extinguished immediately. The afterflame times and afterafterglow times were always zero.

The observations on table 5 and figure $1, b, c, d$ show that there were char formations in the sample areas exposed to the flame. This phenomenon of treated samples may be due to the phosphorus flame retardant agent, which promoted the dehydration of the cotton fabric when the fabric was thermally decomposed [5]. However, the differences in char lengths of the samples were also observed. There was virtually no difference in the char length of the samples treated with 3 different finishing solutions for up to 15 wash cycles. But from 20 washing cycles on, the treated sample with FS3 had much shorter char length than the other two (better flame retardant). Comparing the results of table 5 with the results of table 4 , it is apparent that the $45^{\circ}$ flammability behaviors of treated fabrics were not corresponding to their FR add-on. In order to better understand this phenomenon, the LOI of treated fabrics was investigated.

Table 5

$45^{\circ}$ FLAMMABILITY CHARACTERISTICS

OF CONTROL, TREATED SAMPLES AFTER 0, 5, 10, 15, 20, 30 WASH CYCLES

\begin{tabular}{|c|c|c|c|c|c|}
\hline Sample & $\begin{array}{l}\text { Number } \\
\text { of wash } \\
\text { cycles }\end{array}$ & $\begin{array}{c}\text { Ignition } \\
\text { times } \\
\text { (s) }\end{array}$ & $\begin{array}{c}\text { After } \\
\text { flame } \\
\text { times } \\
\text { (s) }\end{array}$ & $\begin{array}{c}\text { After } \\
\text { glow } \\
\text { times } \\
\text { (s) }\end{array}$ & $\begin{array}{l}\text { Char } \\
\text { length } \\
(\mathrm{mm})\end{array}$ \\
\hline Control & - & 3 & 36 & 9 & $\begin{array}{l}\text { Compl- } \\
\text { etely } \\
\text { burned }\end{array}$ \\
\hline FS1 & \multirow{3}{*}{0} & 9 & 0 & 0 & $20 \pm 1$ \\
\hline FS2 & & 9 & 0 & 0 & $22 \pm 2$ \\
\hline FS3 & & 9 & 0 & 0 & $22 \pm 2$ \\
\hline FS1 & \multirow{3}{*}{5} & 9 & 0 & 0 & $25 \pm 3$ \\
\hline FS2 & & 9 & 0 & 0 & $23 \pm 2$ \\
\hline FS3 & & 9 & 0 & 0 & $26 \pm 2$ \\
\hline FS1 & \multirow{3}{*}{10} & 9 & 0 & 0 & $25 \pm 2$ \\
\hline FS2 & & 9 & 0 & 0 & $25 \pm 2$ \\
\hline FS3 & & 9 & 0 & 0 & $26 \pm 3$ \\
\hline FS1 & \multirow{3}{*}{15} & 9 & 0 & 0 & $26 \pm 2$ \\
\hline FS2 & & 9 & 0 & 0 & $25 \pm 1$ \\
\hline FS3 & & 9 & 0 & 0 & $27 \pm 3$ \\
\hline FS1 & \multirow{3}{*}{20} & 9 & 0 & 0 & $31 \pm 4$ \\
\hline FS2 & & 9 & 0 & 0 & $30 \pm 3$ \\
\hline FS3 & & 9 & 0 & 0 & $27 \pm 2$ \\
\hline FS1 & \multirow{3}{*}{30} & 9 & 0 & 0 & $39 \pm 4$ \\
\hline FS2 & & 9 & 0 & 0 & $41 \pm 3$ \\
\hline FS3 & & 9 & 0 & 0 & $27 \pm 2$ \\
\hline
\end{tabular}

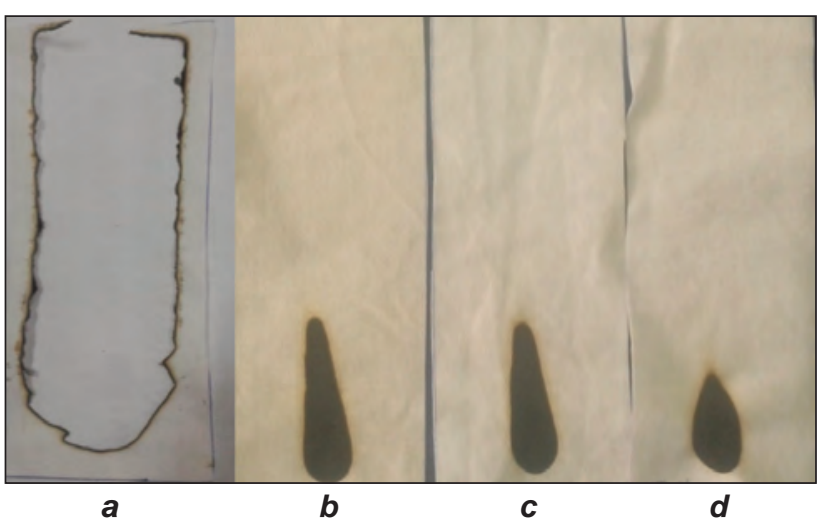

Fig. 1. $45^{\circ}$ flammability of samples: $a-$ Control; $b-\mathrm{FS} 2$ treated sample after 30 washings; $c$ - FS1 treated sample after 30 washings; $d$-FS3 treated sample after 30 washings 
LOI measurement results of fabric

The results of the LOI measurement are presented in table 6.

Table 6

THE LOI OF THE FLAME RETARDANT TREATED COTTON FABRICS WITH DIFFERENT WASHING CYCLES

\begin{tabular}{|c|c|c|c|c|}
\hline \multirow{2}{*}{$\begin{array}{c}\text { Number of } \\
\text { washing cycles }\end{array}$} & \multicolumn{4}{|c|}{ LOI of samples (\%) } \\
\cline { 3 - 5 } & Control & FS1 & FS2 & FS3 \\
\hline 0 & \multirow{4}{*}{14.9} & 33.2 & 36.3 & 26.3 \\
\cline { 1 - 3 } \cline { 4 - 5 } & & 25.0 & 27.2 & 28.5 \\
\cline { 1 - 3 } \cline { 3 - 5 } & & 25.4 & 19.3 & 25.4 \\
\hline 30 & & \multicolumn{3}{|c}{} \\
\hline
\end{tabular}

Unlike the $45^{\circ}$ burning method, the limiting oxygen index technique yielded quantitative results of flammability capacity of the fabric. The results show that the LOI values of treated samples are significantly greater than untreated samples. These differences are $18.3 \%, 21.35 \%$ and $11,4 \%$ for FS1, FS2 and FS3 treated samples, respectively. Compared to the results of table 4 and table 5 , these results could be explained as follows: the low add-on of the FS3 treated sample could be the cause of its low LOI. The LOI of the FS2 treated sample is higher than the FS1 treated sample's LOI while its add-on is smaller. This could be explained by the fact that there was the synergistic effect of phosphorus and nitrogen in the FS2 treated sample, which reduced its flammability. This difference, however, is not reflected in table 5 , which may be due to the fact that the test conditions of $45^{\circ}$ flammability test method are too low for the flameretardant capacity of these three samples.

However, after 20 and 30 laundries, the LOI values of FS3 treated samples were almost unchanged, while these values of FS1, and FS2 treated samples were reduced approximately $8-9 \%$. It was further reduced by $8 \%$ for FS2 treated samples after 30 washings cycles. These results are quite corresponding to the char lengths of samples in table 5 . Thus, the LOI values of the flame retardant treated samples using CA as crosslinking were decreased after washings. This phenomenon has also been observed in other study [8]

The results of tables $4,5,6$ show that in order to create a covalent bond between PR and cotton, the use of CA with ester linkages (Scheme 1) is more favorable than DHEU with ether linkages (case 1 of Scheme 2). However, the flame-retardant laundering durability of CA treated samples is lower than the DHEU treated sample. This phenomenon could be explained by the fact that ester bonds are more easily hydrolyzed in water than ether bonds [24]

The samples were treated by CA and CTS (FS2) have lower flame-retardant laundering durability in comparison with the other two. This suggests that the addition of CTS to the finishing solution without increasing the amount of CA may reduce the crosslink between PR and cotton because the CA could be used to create a link between CTS and cotton.
Influence of flame-retardant treatment on tensile strength of cotton fabric

First, the fabric density was tested in the treated samples, the results are presented in the table 7.

The results of table 7 show that the density of the treated fabrics stay unchanged in comparison with the control fabric. Therefore, the tensile strength of fabric samples that presented in the table 8 was used to assess the influence of flame-retardant treatment on tensile strength of cotton fabric.

\begin{tabular}{|c|c|c|}
\hline \multicolumn{3}{|c|}{ THE FABRIC DENSITY } \\
\hline \multirow{2}{*}{ Samples } & \multicolumn{2}{|c|}{ Fabric density (yarn $/ 5 \mathrm{~cm}$ ) } \\
\hline & Warp & Weft \\
\hline Control samples & 280 & 115 \\
\hline FS1 treated samples & 282 & 117 \\
\hline FS2 treated samples & 282 & 117 \\
\hline FS3 treated samples & 282 & 117 \\
\hline
\end{tabular}

Table 8

\begin{tabular}{|c|c|c|c|c|}
\hline \multirow[b]{2}{*}{ Sample } & \multicolumn{2}{|c|}{ Tensile strength $(\mathrm{N})$} & \multicolumn{2}{|c|}{ Tensile strength (N) } \\
\hline & Warp & $\begin{array}{c}\text { Change } \\
(\%)\end{array}$ & Weft & $\begin{array}{c}\text { Change } \\
(\%)\end{array}$ \\
\hline Control & 899.3 & - & 532.8 & - \\
\hline FS1 & 506.3 & -43.7 & 328.1 & -38.4 \\
\hline FS2 & 428.4 & -52.4 & 282.1 & -47.0 \\
\hline FS3 & 657.8 & -26.9 & 417.6 & -21.6 \\
\hline
\end{tabular}

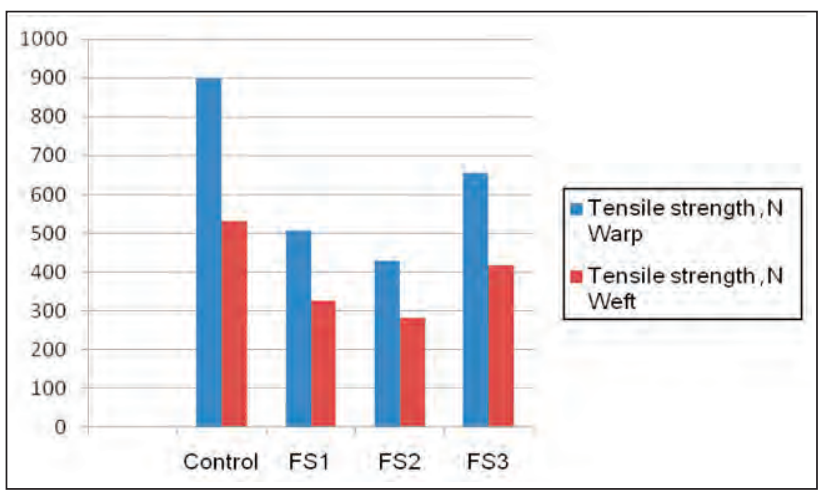

Fig. 2. Tensile strength of the control and treated samples

Table 8 and figure 2 show that, the tensile strength of the treated samples was significantly reduced compared to the untreated samples. This mechanical strength loss in the direction of warp yarn is greater than in the direction of the weft yarn. The biggest drop is for CTS and CA treated sample, then for CA treated sample and finally for the treated sample with FFRC. It could be said that the treatment in the acidic environment and curing at high temperature could be 
the cause of this mechanical strength loss. In this study, all of the three samples were treated at $180^{\circ} \mathrm{C}$ for 2 minutes, but the $\mathrm{pH}$ of finishing solution with FFRC was $6 \div 6.5$, while the $\mathrm{pH}$ of solution using $\mathrm{CA}$ and the one using CA plus CTS were only $5.3 \div 5.5$. It is possible that the difference in $\mathrm{pH}$ of the solutions leads to the difference in tensile strength of these three treated samples. The mechanical strength loss of cellulosic flame retardant treated fabrics has also been reported in several studies [10-12, 25]. However, study [10] indicates that this tensile strength loss was even observed for the cotton fabric treated only with PR without CA. Thus, the tensile strength loss is one important problem of the flameretardant treatment for cotton fabrics. PR and CA concentrations, temperature and time of curing are factors that need to be carefully selected so that the tensile strength loss is minimal.

\section{Formaldehyde content}

Results of the hydrolyzed formaldehyde amounts determined by the ISO 14184-1:1998 method are shown in table 9.

Table 9

FREE FORMALDEHYDE AMOUNT DETERMINED ACCORDING TO ISO 14184-1:1998

\begin{tabular}{|c|c|c|}
\hline Sample & $\begin{array}{c}\text { Number of washing } \\
\text { cycles }\end{array}$ & $\begin{array}{c}\text { Free formaldehyde } \\
\text { (ppm) }\end{array}$ \\
\hline FS1 & 0 & 258 \\
\hline FS2 & 0 & 246 \\
\hline FS3 & 0 & 140 \\
\hline FS1 & 1 & 103 \\
\hline FS2 & 1 & 110 \\
\hline FS3 & 1 & 122 \\
\hline
\end{tabular}

The results show that the free formaldehyde of samples treated with FS1 and FS2 is about 1.8 times higher than FS3 treated samples. This difference is corresponding to the difference in add-on values between these samples (table 4). Therefore, free formaldehyde could be derived primarily from $\mathrm{PR}$ and the difference in value of free formaldehyde may be due to the PR content of the treated sample, not due to CA. This finding confirms Drago Katovic's observation $[8,26]$ that cotton fabric which was treated only with PR without crosslinking may also have free formaldehyde more than 300 ppm.
However, in this study, the free formaldehyde content of all treated samples is less than 300 ppm, it fulfills the criterion of OEKO-TEX® standard 100 for not direct skin apparel fabrics. In addition, after only one wash, this value decreases to about 100 ppm for all three treated samples (table 9).

\section{CONCLUSION}

The results from this study show that Pyrovatex CP New provides durable flame retardancy on cotton fabric. The treated samples show good flame retardancy against the $45^{\circ}$ flammability test even after 30 wash cycles. However, the tensile strength of the treated fabrics decreased significantly, the highest reduction was $52 \%$ for fabrics treated with CA and CTS, and at least $26 \%$ for fabrics treated with Knittex FFRC. Furthermore, the treated fabrics released free formaldehyde. This free formaldehyde content is correlated to the amount of add-on of treated fabric.

The treated fabrics, using Knittex FFRC as the crosslinking, have the lowest LOI value, but the lowest loss of tensile strength and the lowest formaldehyde content. They are the best durable fire retardants. Compared to Knittex FFRC, the fabrics treated with crosslinking CA have a higher LOI value, but lower washing durability of fire resistance, higher formaldehyde content (formaldehyde content released from PR) and higher loss of tensile strength.

When adding CTS to the finishing solution using CA, the fire-retardant capacity of the treated fabric increased, but flame retardant washing durability was lower and the loss of tensile strength was also higher. Thus, Knittex FFRC and CA are both formaldehydefree finishing agents

Knittex FFRC suggests that it is a durable cross-link for fire retardant cotton fabrics using Pyrovatex CP New. It can reduce the negative impact on the mechanical strength of the treated fabric compared to the use of CA.

However, if the fire-retardant fabric is required to have a high LOI but is not required to have high fire retardant washing durability and the high mechanical strength, CA may be an effective crosslinking agent.

\section{ACKNOWLEDGMENTS}

This work was comprehended in the framework of project KC.02.13/16-20 which is financed by the MOST of Vietnam. The authors wish to sincerely thank KC.02/16-20 program, Chemical-textile LAB, Testing center of textile leather materials and Laboratory of Polymer and Composite Materials of HUST for supports during our research.

\section{REFERENCES}

[1] Jiang., et al., Enhanced flame retardancy of cotton fabrics with a novel intumescent flame-retardant finishing system, In: Fibers and Polymers, 2015, 16, 2, 388-396

[2] Visakh, P.M., Flame retardants, 2015, London, Engineering Materials

[3] Khandual, A., Green flame retardants for textiles, In: Green fashion, 2016, Springer, 171-227

[4] Magovac, E., Bischof, S., Non-halogen FR treatment of cellulosic textiles, In: Tekstil: časopis za tekstilnu tehnologiju i konfekciju, 2015, 64, 9-10, 298 
[5] Zheng, D., Zhou, J., Zhong, L., Zhang, F., Zhang, G., A novel durable and high-phosphorous-containing flame retardant for cotton fabrics, In: Cellulose, 2016, 23, 3, 2211-2220

[6] Yoshioka-Tarver, M., et al., Influence of NP Base Fiber Reactive Organophosphorus Flame Retardant on Cotton Thermal Behavior, In: AATCC Review: the magazine of the textile dyeing, printing, and finishing industry, 2012, 12, $5,52-59$

[7] Charuchinda, S.,Srikulkit, K., Mowattana, T., Co-application of sodium polyphosphate and chitosan to improve flame retardancy of cotton fabric, In: Journal of Scientific Research, Chulalongkorn University, 2005, 30, 1, 97-107

[8] Katović, D., Grgac, S.F., Bischof-Vukušić, S., Katović, A., Formaldehyde free binding system for flame retardant finishing of cotton fabrics, In: Fibres \& textiles in Eastern Europe, 2012, 1, 90, 94-98

[9] Mengal, N., Syed, U., Malik, S.A., Ali Sahito, I., Jeong, S.H., Citric acid based durable and sustainable flame retardant treatment for lyocell fabric, In: Carbohydr Polym, 2016, 153, 78-88

[10] Mohsin, M., Ahmad, S.W., Khatri, A., Zahid, B., Performance enhancement of fire retardant finish with environment friendly bio cross-linker for cotton, In: Journal of Cleaner Production, 2013, 51, 191-195

[11] Poon, C-K., Kan, C-W, Effects of TiO2 and curing temperatures on flame retardant finishing of cotton, In: Carbohydrate polymers, 2015, 121, 457-467

[12] Yasin, S., Behary, N., Giraud, S., Perwuelz, A., In situ degradation of organophosphorus flame retardant on cellulosic fabric using advanced oxidation process: A study on degradation and characterization, In: Polymer Degradation and Stability, 2016, 126, 1-8

[13] Uddin, F., Recent development in combining flame-retardant and easy-care finishing for cotton, In: Cellulose Chem. Technol, 2013, 47, 5-6, 469-477

[14] Erkan, G., Sarışık, M., Antifungal microcapsules of ethyl cellulose by solvent evaporation and their application to cotton fabric, In: Fibres \& Textiles in Eastern Europe, 2015

[15] Mohsin, M., et al., Softener impact on environment friendly low and zero formaldehyde cross-linker performance for cotton, In: De redactie, 2013, 133

[16] El-Tahlawy, K., Chitosan phosphate: A new way for production of eco-friendly flame-retardant cotton textiles, In: Journal of the Textile Institute, 2008, 99, 3, 185-191

[17] Sireerat C., Kawee S., Mowattana T., Co-application of Sodium Polyphosphate and chitosan to improve Flame Retardancy of Cotton Fabric, In: J. Sci. Res. Chula. Univ, 2005, 30, 1

[18] Stevens, C., Smith, B., Cross-linking of cotton cellulose with ethylene urea derivatives having varying hydrogenbonding capabilities: Part I: Effects on the physical properties and the hydrogen-bonded structure, In: Textile Research Journal, 1970, 40, 8, 749-760

[19] NF EN ISO 6330 - Domestic washing and drying procedures for textile testing, 2002, French

[20] ASTM D 1230 - Standard test method for flammability of apparel textiles, In: Philadelphia, PA: American Society for Testing and Materials, 1994

[21] ASTM D 2863 - Standard Test method for measuring the minimum oxygen concentration to support candle-like combustion of plastics (oxygen index), 1997

[22] BS EN ISO 13934-1:2013 Textiles - Tensile properties of fabrics - Part 1: Determination of maximum force and elongation at maximum force using the strip method (Iso 13934-1:2013), 2013

[23] NF EN ISO 14184-1 : 2011 Textiles - determination of formaldehyde - Part 1: Free and hydrolyzed formaldehyde (water extraction method), 2011

[24] Deruiter, J., Ethers and thioethers, 2005, Principles of Drug Action 1, Spring 2005, Ethers

[25] Abou-Okeil, A., El-Sawy, S., Abdel-Mohdy, F., Flame retardant cotton fabrics treated with organophosphorus polymer, In: Carbohydrate polymers, 2013, 92, 2, 2293-2298

[26] Mohsin, M., Ramzan, N., Qutab, H.G., Ahmad, S.W., Sarwar, N., Synthesis of halogen and formaldehyde free bio based fire retardant for cotton, In: Industria Textila, 2017, 68, 3, 221-225, http://doi.org/10.35530/ IT.068.03.1328

Authors:

\section{VU THI HONG KHANH ${ }^{1}$, NGUYEN THI HUONG ${ }^{1,2}$}

${ }^{1}$ Hanoi University of Science and Technology, No. 1, Dai Co Viet, Hai Ba Trung, Hanoi, Viet Nam

${ }^{2}$ Hanoi Industrial Textile Garment University, Le Chi, Gia Lam, Hanoi, Viet Nam e-mail: khanh.vuthihong@hust.edu.vn, nguyenhuonghict@gmail.com

Corresponding author:

VU THI HONG KHANH

e-mail: khanh.vuthihong@hust.edu.vn 


\title{
Facile fabrication of functional bra cup by an automated dispensing system
}

\author{
DOI: 10.35530/IT.070.05.1583
}

YING ZHANG

TAO LI

CHENG-HAI YU

FENG-YUAN ZOU

\section{ABSTRACT - REZUMAT}

\section{Facile fabrication of functional bra cup by an automated dispensing system}

The goal of the study is to develop a novel method to manufacture the functional bras. The high precision three-dimensional (3D) scanner was employed to get the point cloud data. A fixed mount was invented to keep the bra cup stable and decrease measuring error. A bottom holder was prepared by the $3 D$ printer to place the bra cup during the injection process. Furthermore, the injection points coordinate values and the injection volumes can be determined based on the 3D image of the bra cup and the thickness of those positions. At last, the three-axis automatic robot which was coupled with a precision liquid dispenser is used to inject the microcapsules solution into the bra cup for the preparation of functional intimate apparel. The proposed method was verified to be feasible and effective through a practical example.

Keywords: functional bras, 3D scanner, data acquisition, 3D printer, automated dispensing systems, microcapsules solution

\section{Realizarea cupei funcţionale a sutienului cu un sistem automat de distribuire}

Obiectivul studiului a fost de a dezvolta o metodă nouă pentru fabricarea sutienelor funcționale. Scanerul tridimensional (3D) de înaltă precizie a fost utilizat pentru a obține datele antropometrice. A fost dezvoltat un sistem de montare fix pentru a menține cupa sutienului stabilă și pentru a reduce eroarea de măsurare. Pentru imprimanta $3 D$ a fost realizat un suport, pentru a așeza cupa sutienului în timpul procesului de injecție. Mai mult, valorile coordonatelor punctelor de injecție și volumele de injecție au putut fi determinate pe baza imaginii 3D a cupei sutienului și a grosimii respectivelor poziții. În cele din urmă, robotul automat cu trei axe, care a fost cuplat la un distribuitor precis de lichid, a fost utilizat pentru a injecta soluția de microcapsule în cupa sutienului pentru realizarea produselor de lenjerie funcționale. Metoda propusă a fost verificată ca fiind fezabilă și eficientă printr-un exemplu practic.

Cuvinte-cheie: sutiene funcționale, scaner $3 D$, achiziție de date, imprimantă $3 D$, sisteme de distribuire automată, soluție de microcapsule

\section{INTRODUCTION}

Women's satisfactions with intimate apparel, especially bras, have developed from a necessity into a multi-functional item [1-2]. New technologies have been introduced to develop innovative preparation methods to meet consumer demand for the pursuit of beauty and function [3]. However, the growth of functional bra in the commercial market lags behind the research. This may due to the poor durable functionality finished by traditional process [4]. A smart finishing process should be exploited to make full use of the special three-dimensional shape of bra. With the development of high precision three-dimensional (3D) scanning technique, it will be possible to acquire point cloud data of bra cup. Irregular triangle patches obtained from those points can generate completed bra cup data which is reliable and high accurate [56]. Meanwhile, automated dispensing system provides a direct way of dispensing finishing liquids on/into the fabrics [7]. In this study, the most common material of bra, polyurethane (PU) foam was used given its soft and flexible characteristics [8-9]. Moreover, $\mathrm{PU}$ is available in a wide range of softness and thickness, which not only provides unlimited shape designs, but also has sufficient interspace for loading the functional materials and avoiding the washing influence on the durability [10-11]. Microcapsules finishing agent is used since it is an effective method to protect functional material and control the release rate of various agents [12-13]. Therefore, combining the 3D scanning technique and automated dispensing systems can inject the different kinds of functional microcapsules solution into the bras according to the calculated position and volume to realize the durable functionality.

In this work, the microcapsules solution was injected into the PU bra cup precisely by an automated dispensing machine. First of all, the geometrical data of bra cup was acquired by the three-dimensional scanning technique. Then, the holder of the bra was made by the 3D printer. Also, injection information of the sample was determined by an adaptive program and written into three-axis automatic robot coupled with a precision dispenser. Finally, the manipulator would bring the needle to the pre-set injection position and finish the injection process. The results demonstrated 
that this novel method is effective to realize the manufacturing of the functional bra cups.

\section{EXPERIMENTAL SECTION}

\section{Materials}

Flexible polyurethane (PU) bra cups with a thickness of ca. $30 \mathrm{~mm}$ were kindly gifted from Shan Wai Shan Garment Co., Ltd., China. The size of this bra cup is $75 \mathrm{~B}$ which regarded as the typically standard in the Chinese women's lingerie market. The microcapsule solution was purchased from Herst International Group, China. The low temperature adhesive was obtained from Transfar Co., Ltd., China. The thickening agent was purchased from Rui Guang Industrial Co., Ltd., China.

\section{Data acquisition of the bra cup}

Accurate data acquisition is the basis of determining the injection location. Since the bra cup is a soft and irregular object, it is not very accessible to get its geometric information by contact measurement method [14]. Therefore, a high-precision 3D scanner (EaScan-D, Xian Lin Co., Ltd., China) with a precision of $0.05 \mathrm{~mm}$ was employed in our approach. The optical blue light 3D digitization system can capture the images quickly and combine them automatically based on the mark points. Since PU foam cups can easily deform, we used an apparatus attached with fixtures to ensure that the bra cup sample was positioned in a stable manner during the scanning process. The material of this fixed mount is PMMA which allows light to pass through. If the mark points are adhered on the sample, it will prevent scanning complete bra cups or decrease accuracy. Therefore, the mark points were adhered on the bottom of the fixed mount, which is shown in figure 1. Furthermore, the fixed mount is adjustable to accommodate bra cups with different styles or different sizes. It is remarkable that the bra cup was clamped by the fixed mount. Then, the bra cup was arranged in its nature state and the deformation would not happen. Nonetheless, the bra cup was scanned for several times to ensure precise 3D data. The reverse engineering software Geomagic was employed for merging and curvature smoothing. Data file was exported as a STL file for the subsequent processes carried out.

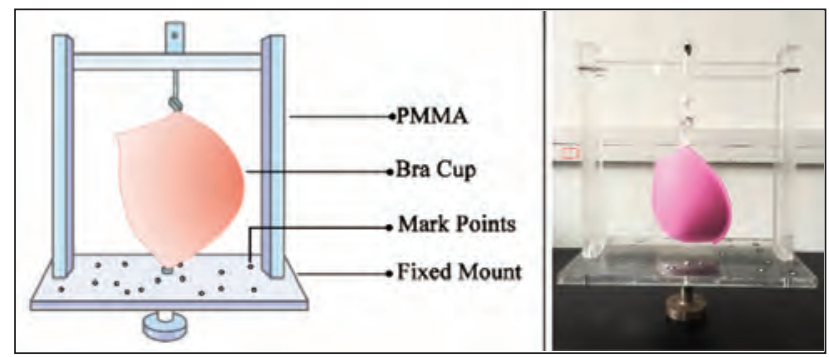

Fig. 1. The apparatus of bra cup fixed mount for scan measurement

\section{Determination of the bra cup apex}

In this approach, the bra cup should be horizontally placed onto the $X Y$ plane during the injecting process.
The position of bra cup peak was defined as the lowest point of contact surface. To obtain the apex of the bra cup on the outer surface, a base plane was built based on the theory of three points determining a plane. These three points are the left endpoint, the midpoint and the right endpoint of the bowl line bundle of the bra cup. The point with the biggest projection distance between the outer surface and the bottom horizontal plane was regarded as the apex of bra cup (see figure 2).

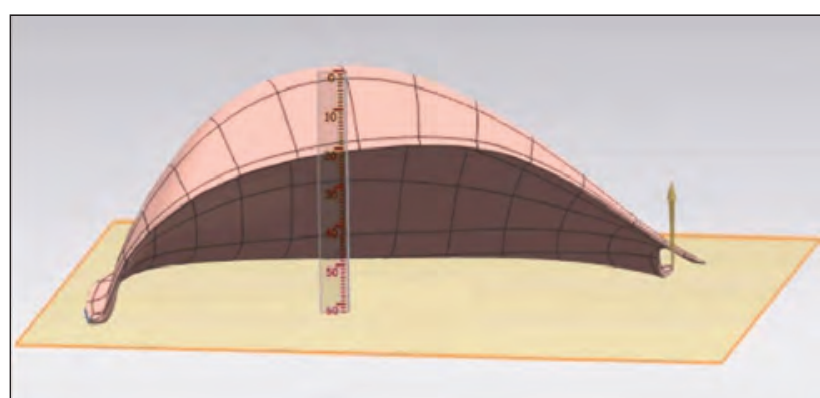

Fig. 2. Determination of the position of bra cup peak

\section{The fabrication of the bra cup holder}

As stated previously, the bra cup is irregular and flexible. Therefore, it is necessary to fabricate a holder to keep the bra cup stable during the injecting process. Firstly, the coordinate origin should be determined according to the minimum bounding box [15]. Given the bra cup in three dimensional spaces, the maximum values in $X Y, X Z, Y Z$ planes all can be obtained. The schematic diagram of finding out the minimum bounding box of the bra cup is displayed in the figure 3 , and the pseudo code is given as follow:

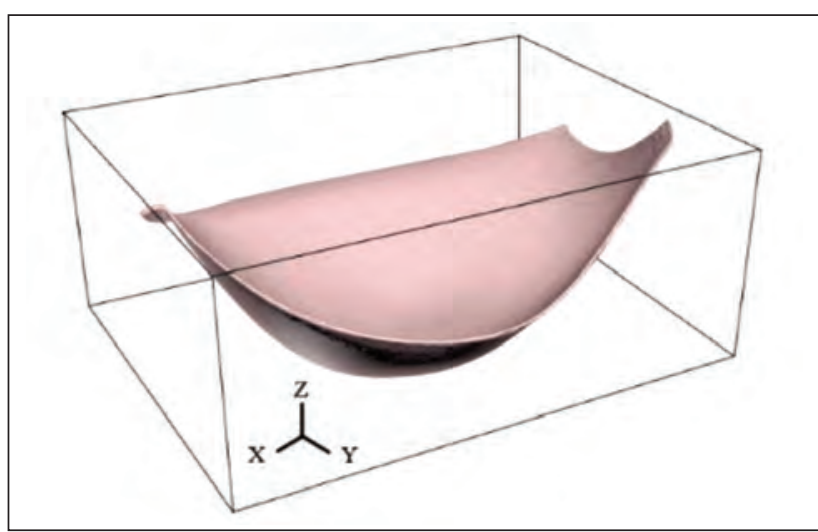

Fig. 3. Finding out the minimum bounding box of the bra cup

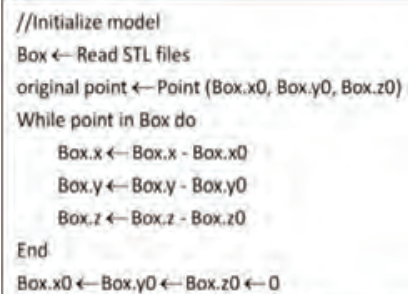

the sample step of injection points (box.x0, box.y0, box.xn, box.yn) is border of the box $\leftarrow s t^{*}$ 
The reset bra cup file was obtained and exported as a new STL file. The upper surface of the hold should be matched well to the bottom surface of the bra cup. The method of making the bra cup holder can be narrated below:

Step 1 The new bra cup file was imported in the reverse engineering software Geomagic. All data of the bra cup inner surface were deleted.

Step 2 The outer surface margin of the bra cup was smoothed. In terms of the outer surface margin, the projection was built on the XY plane.

Step 3 In order to display the coordinate origin, the bounding box of the bra cup, the four boundaries (i.e., top, bottom, left, and right ones) were marked and these edges were thickened by $10 \mathrm{~mm}$ on the $Z$ axis. The holder model of the bra cup is shown in figure 4.

Step 4 The new holder model was saved as a STL file which could be made directly by the $3 D$ printer using the PLA as the material.

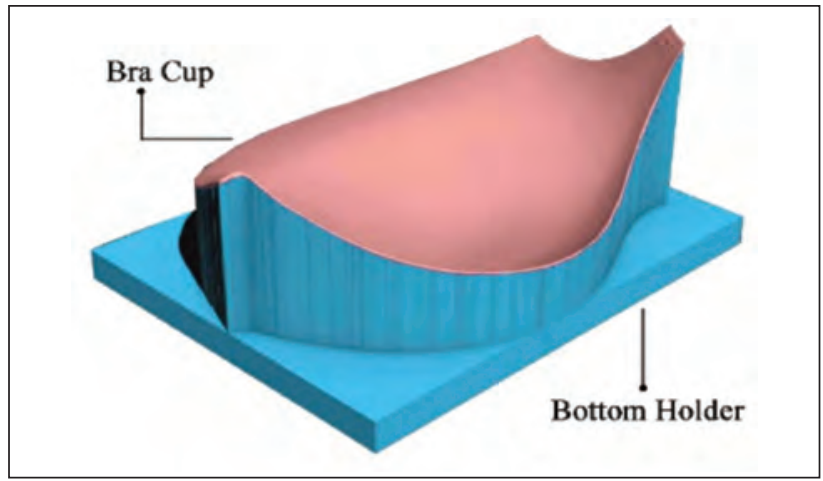

Fig. 4. The holder model of the bra cup

\section{Microcapsules solution preparation}

The microcapsules solution was consisted of $10 \mathrm{wt} \%$ PU microcapsules, 15 wt $\%$ low temperature adhesive, $1 \mathrm{wt} \%$ thickener, and $74 \mathrm{wt} \%$ deionized water. The solution was stirred at $60^{\circ} \mathrm{C}$ for 20 minutes to ensure the microcapsules solution adequate homogeneous.

\section{RESULTS AND DISCUSSION}

The automated dispensing is an efficient and effective way to deliver the solution to the designated location [16]. Especially, a home brew software was programmed, which can determine injection positions and volumes intelligently according to thickness of the points. In this software step distance and injection point number are two input parameters which could codetermine the injection positions. When the step distance was confirmed, the number of the points within $X Y$ plane was also determined. Those points were ranked in descending order based on the height difference in the Z-axis. The high ranked points were selected as the injection position and the number of those points was determined based on number preset. Furthermore, the injection dose of each point could be calculated by our software according to the Equation (1).

$$
V_{e}=H_{e} \times V_{t} / \sum_{i=1}^{n} H_{e}
$$

where $V_{e}$ represents the injection dose of each point, $V_{t}$ - the total amount of the finishing liquid, $H_{e}$ - the height difference of each injection position, and $n-$ the number of the injection points.

The injection depth is set as $1 / m$ of the thickness difference between upper surface and bottom surface, and the $m$ can be any number greater than 1. In this example, the injection depth was set as the half of thickness difference (i.e., $m=2$ ). The step distance, number of injection points, and total volume of the injection were set as $20 \mathrm{~mm}, 10$ and $5 \mathrm{~mL}$, respectively. The injection position detailed information is shown in the table 1, and the simplified pseudo code is given as follow.

Table 1

\begin{tabular}{|c|c|c|c|c|}
\hline \multicolumn{5}{|c|}{ DETAILED INFORMATION OF INJECTION POSITIONS } \\
\hline No. & Position X & Position Y & Position Z & $\begin{array}{c}\text { Injection } \\
\text { volume } \\
(\mathbf{m L})\end{array}$ \\
\hline 1 & 80.00 & 60.00 & 17.82 & 0.59 \\
\hline 2 & 60.00 & 60.00 & 17.19 & 0.57 \\
\hline 3 & 80.00 & 80.00 & 24.23 & 0.57 \\
\hline 4 & 60.00 & 80.00 & 24.49 & 0.56 \\
\hline 5 & 100.00 & 60.00 & 22.53 & 0.52 \\
\hline 6 & 100.00 & 80.00 & 26.94 & 0.49 \\
\hline 7 & 40.00 & 60.00 & 22.38 & 0.46 \\
\hline 8 & 40.00 & 80.00 & 29.11 & 0.42 \\
\hline 9 & 80.00 & 40.00 & 12.78 & 0.42 \\
\hline 10 & 60.00 & 40.00 & 12.27 & 0.40 \\
\hline
\end{tabular}

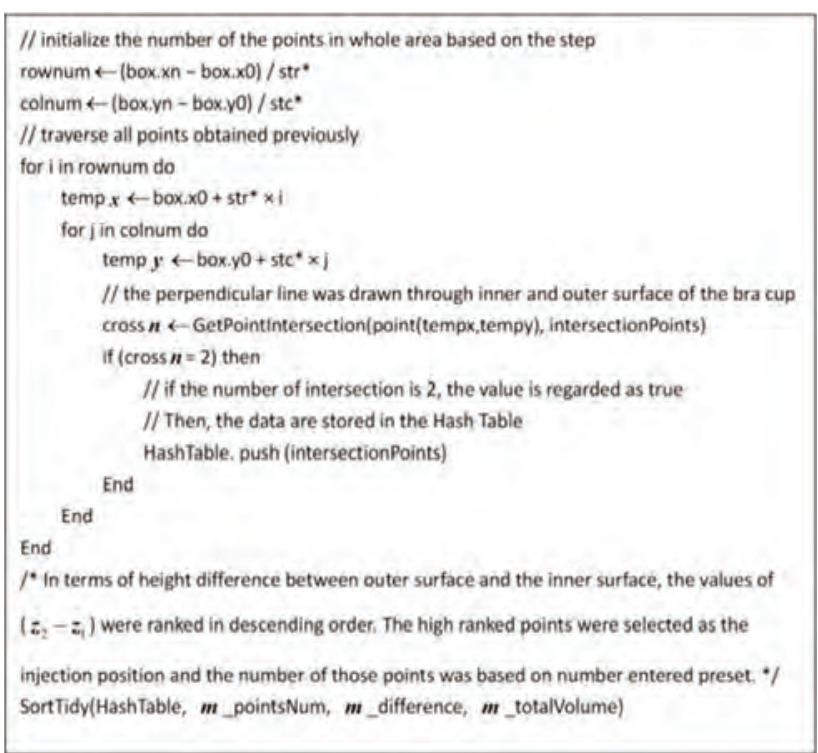

A desktop three-axis automatic robot system with precision liquid dispenser (TS-300B, Ten Sun Industrial Equipment Co., Ltd., China) was applied to deliver and inject the microcapsules solution. The 


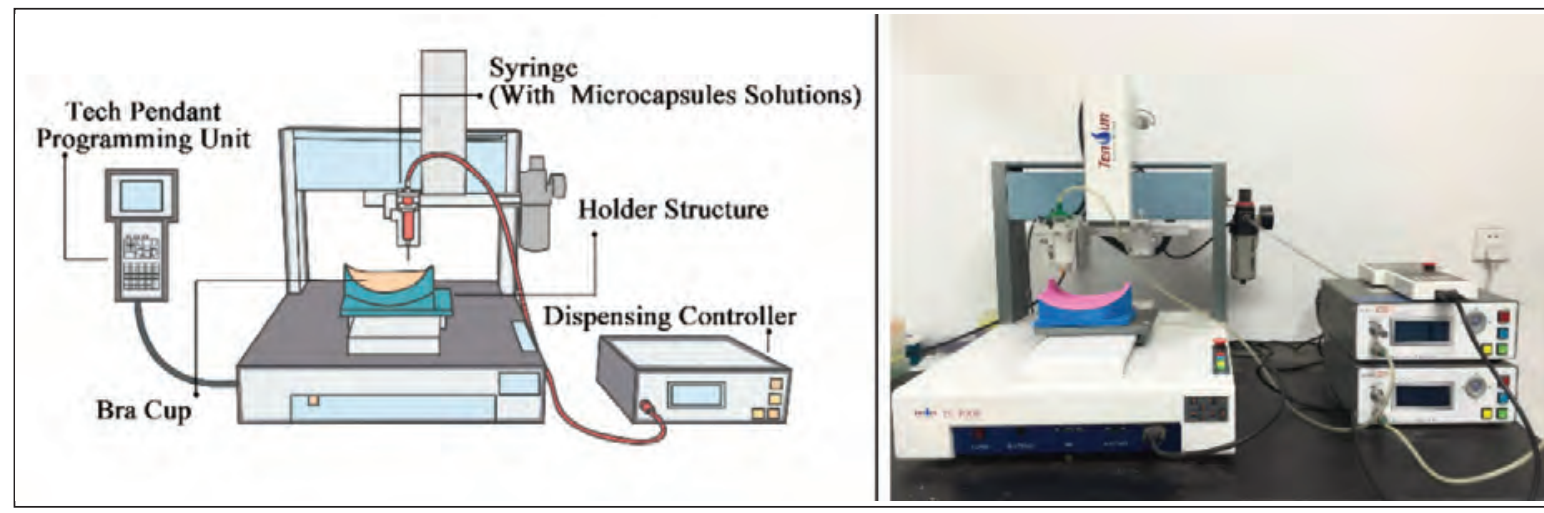

Fig. 5. Automatic dispensing system

mechanical arm attached with a needle of $0.11 \mathrm{~mm}$ in diameter and $32 \mathrm{~mm}$ in length can linear move independently in the $\mathrm{X}, \mathrm{Y}$ and $\mathrm{Z}$ directions. A schematic of such fully automated dispensing system is shown in figure 5 . The injection information was written with the teach pendant to deliver the microcapsules solutions accurately to the desired spots.

The injection volumes were controlled by the air pump pressure and dispensing time. To control injection volume accurately, the pump pressure, injection time and solution destiny were tested. The destiny of the microcapsule solution is $1.005 \mathrm{~g} / \mathrm{mL}$ measured using a force tensiometer (K100, Krüss, Germany) at $25^{\circ} \mathrm{C}$. The relation of the pump pressure and dispensing time to solution weight was measured by a precision balance (ME104E, Mettler-Toledo, Switzerland) at $25^{\circ} \mathrm{C}$. The injection rate was set as $0.05 \mathrm{~mL} / \mathrm{s}$ in the condition of pump pressure of $48 \mathrm{kPa}$. The drying treatment step was done at $80^{\circ} \mathrm{C}$ for 50 minutes (to evaporate the water) and $120^{\circ} \mathrm{C}$ for 10 minutes (to ensure adequate adhesive cross linking).

\section{CONCLUSIONS}

In this paper, a new method of automated dispensing functional microcapsule solution for bra cup is presented. Complete and accurate 3D data of bra cup can be obtained with the fixing of the fixed mount. The bottom holder ensures that the bra cup keep stable during the injection process. A parameterization program makes it possible to determine the injection location and dose smartly based on the bra cup thickness information. Furthermore, with this novel technique, the functional liquid can be dispensed accurately to the surface or interior of the irregularly shaped three-dimensional fabrics which are not limited to the bra cup.

\section{ACKNOWLEDGEMENTS}

This study is financially supported by the Zhejiang Provincial Collaborative Innovation Center of Garment Personalized Customization.

\section{REFERENCES}

[1] Beti, R.C., Slavica, B., Drago, K., Tencel with a microbial barrier for medical bras, In: Journal of Fiber Bioengineering and Informatics, 2015, 8, 4, 635-643

[2] Yick, K.L., Wu, L., Yip, J., Ng, P., Yu, W., An evaluation of the three-dimensional geometric shape of moulded bra cups, In: Fibers and Polymers, 2011, 12, 4, 556-563

[3] Kin, E.A., Yoo, S.J., Kim, J.J., Development of a human-clothing-environment simulator for dynamic heat and moisture transfer properties of fabrics, In: Fibers and Polymers, 2003, 4, 4, 215-221

[4] Li, L., Song, L., Hua, T., Au, W.M., Wong, K.S., Characteristics of weaving parameters in microcapsule fabrics and their influence on loading capability, In: Textile Research Journal, 2013, 83, 2, 113-121

[5] Yick, K.L., Wu, L., Yip, J., Ng, S.P., Yu, W., Study of thermal-mechanical properties of polyurethane foam and the three-dimensional shape of molded bra cups, In: Journal of Materials Processing Technology, 2010, 210, 1, 116-121

[6] Choi, G.B., Kim, S.M., Adaptive modeling method for 3 - D printing with various polymer materials, In: Fibers and Polymers, 2016, 17, 7, 977-983

[7] Li, B., Li, D.P., Wang, J.P., Copper deposition on textiles via an automated dispensing process for flexible micro strip antennas, In: Textile Research Journal, 2014, 84, 19, 1-10

[8] Wu, L., Yick, K.L., Ng, S.P., Yip, J., Application of the box-behnken design to the optimization of process parameters in foam cup molding, In: Expert Systems with Applications, 2012, 39, 1, 8059-8065

[9] Wu, L., Yick, K.L., Ng, S.P., Yip, J., Kong, K.H., Parametric design and process parameter optimization for bra cup molding via response surface methodology, In: Expert System with Applications, 2012, 39, 9, 162-171 
[10] Yip, J., Ng, S.P., Study of three-dimensional spacer fabrics: molding properties for intimate apparel application, In: Journal of Materials Processing Technology, 2009, 209, 1, 58-62

[11] Yu, W.M., Yeyng, K.W., Harlock, S.C., Leaf, G.A.V., Predicting energy requirements for moulding flexible polyurethane foam sheets, In: Textile Research Journal, 1998, 68, 4, 289-295

[12] Tülay, G., The role of microcapsules in masking bad odors of cotton fabrics, In: Industria Textila, 2017, 68, 4, 275-282, https://doi.org/10.35530/IT.068.04.1289

[13] Li, S., Boyter, H., Qian, L., UV curing for encapsulated aroma finish on cotton, In: The Textile Institute, 2005, 96, 6, 407-411

[14] Yick, K.L., Ng, S.P., Zhou, X.J., Yu, W., Chan, D., Wire frame representation of 3D moulded bra cup and its application to example-based design, In: Fibers and Polymers, 2008, 9, 5, 653-658

[15] Chan, C.K., Tan, S.T., Determination of the minimum bounding box of an arbitrary solid: an iterative approach, In: Computer Structures, 2001, 79, 15, 1433-1449

[16] Peddi, A., Zhen, Y.F., Cherezov, V., Caffrey, M., Efficient and effective path for automated dispensing of bioprecipitant solutions, In: Proceedings of the 2005 IEEE International Conference on Automation Science and Engineering, 2005, 61-66

Authors:

YING ZHANG ${ }^{1,2}$, TAO LI ${ }^{1}$, FENG-YUAN ZOU1,2, CHENG-HAI YU³, LEI DU1,2

${ }^{1}$ School of Fashion Design \& Engineering, Zhejiang Sci-Tech University, Hangzhou 310018, China ${ }^{2} Z$ hejiang Provincial Research Center of Clothing Engineering Technology, Hangzhou 310018, China ${ }^{3}$ School of Information Science and Technology, Zhejiang Sci-Tech University, Hangzhou 310018, China

Corresponding author:

LEI DU

e-mail: dulei@zstu.edu.cn 


\section{Integrated UAS system - Single skin textile wing \\ DOI: 10.35530/IT.070.05.1616}

\section{ABSTRACT - REZUMAT}

\section{Integrated UAS system - Single skin textile wing}

This paper depicts the early phase of development for an integrated system tailored for emergency response actions and remote sensing. This paper focuses on the support system envisioned as an integrated Unmanned Aerial System (UAS) system that consists of one or more ultra light multifunctional aerial units with a configuration that can be adapted to the nature of the intervention: monitoring, mapping, observation and logistics etc.

Starting from wing airfoil and material selection and ending with the experimental model manufacture, the paper will present the development of a single sail paraglider wing that can meet the operational demands for emergency response situations. The wing was designed mainly to have an easy handling and to have a predictable deployment at all times. The entire system and the aerial units were designed with increased modularity in order to be tailored for specific operational requirements of the intervention.

Keywords: Unmanned Aerial System (UAS), parachute, paraglider

\section{Sistem integrat UAS - Aripă textilă cu un singur strat}

Această lucrare prezintă faza de început a proiectării unui sistem integrat adaptat pentru acțiuni de răspuns în caz de urgență și teledetecție. Această lucrare se concentrează asupra unui sistem de asistență imaginat ca un sistem UAS (Unmanned Aerial System) integrat care constă dintr-una sau mai multe unități aeriene multifuncționale, ultra-ușoare, cu o configurație care poate fi adaptată la natura intervenției: monitorizare, cartografiere, observație și logistică etc. Începând cu selecția profilului aerodinamic și a materialului textil pentru aripă și terminând cu fabricarea modelului experimental, lucrarea va prezenta dezvoltarea unei aripi de parapantă cu o construcţie dintr-un singur strat care poate satisface cerințele operaționale pentru situații de răspuns la situații de urgență. Aripa a fost proiectată în principal pentru a avea o manevrare ușoară și pentru a avea o deschidere previzibilă în orice condiții. Întregul sistem și unitățile aeriene au fost proiectate cu o modularitate crescută pentru a fi adaptate cerințelor operaționale specifice ale intervenției.

Cuvinte-cheie: aeronavă fără pilot (UAS), parașută, parapantă

\section{INTRODUCTION}

Emergency response is a series of organized and coordinated precaution and actions during the time between the detection of possible event and stabilizing the situation. An emergency response decision support system needs to assist decision makers to evaluate emergency plans and select an appropriate plan of action during an emergency by supporting heterogeneous emergency response data sources and providing decision makers with access to appropriate emergency rescue knowledge. It also needs to provide differentiated services to meet particular requirements.

Decision making in emergency response is an extremely time-sensitive and challenging task that requires immediate and effective response from decision makers who are surrounded by a variety of uncertain information and are under huge pressure from the need to coordinate action. An emergency response decision support system needs to assist decision makers to evaluate emergency plans and select an appropriate plan of action during an emergency by supporting heterogeneous emergency response data sources and providing decision makers with access to appropriate emergency rescue knowledge. It also needs to provide differentiated services to meet particular requirements.

There are four main emergency response functions emergency assessment, risk operations, population protection and incident management. The four functions provide a framework for organizing response activities to a wide variety of emergencies, natural hazards, technological accidents, terrorist attacks, and sabotage [1].

Emergency assessment: The emergency response activities in the response phase relate to the understanding of the behavior of the hazard-generating factors but also of the risk to human life and material damage.

Risk operations: Risk operations aim at mitigating emergency situations but are only implemented when needed. Their applicability varies greatly from one hazard to another.

Protection of the population: The information collected during the emergency assessment is the basis for the choice of population protection actions. 
Incident management: Incident management involves the development of an incident management policy, a set of consistent, repeatable, measurable processes and procedures and the use of appropriate administrative, managerial, technical or legal means to detect analyze and respond to incidents serious.

Regardless of the emergency structure that acts against the timer, time is the greatest enemy, and the scoring scale is the response time, which must be very low. With the latest Unmanned Aerial Vehicles (UAV) technology, the risks that influence response time can be reduced.

Also, unmanned aerial devices allow convenient remote sensing with the convergence of many technologies like micro-electronics, auto-piloting, highcharge batteries, super materials that are strong yet lightweight, wireless communication, compact digital cameras, image-processing software, miniaturization of GNSS and INS, and so on - all of these novelties created synergy. However, the key to the success of an UAS for remote sensing lay not only in the hardware and electronics but also in the ability of today's software to automatically derive orthoimages and DEMs from overlapping digital images and airborne Lidar point clouds. The scientific fields of computer vision and artificial intelligence have definitely contributed to the development of the backbone of UAS through fundamental research. Indeed, today's photogrammetric software supports high automation of the entire chain, from flight planning, self-calibration of consumer-grade cameras and aero-triangulation through automatic block adjustment up to the creation of DEMs and orthomosaics as well as their confluence: 3D city models and 3D virtual landscapes in which a surveyor can place a cursor, as if it were a rod, over a terrain point from the comfort of an office. Field survey is only necessary when high-precision georeferencing is required, and this is done by measuring through differential GNSS the coordinates at sub-centimetre level of around half a dozen ground control points (GCPs) evenly distributed along the borders of the area. As a result, the full survey, from flight planning up to the final georeferenced products, can be conducted in just one or two days.

Starting from the premise that the way of manifestation of the emergency situations and their management system in the future will be very different from the past context, we have proposed to develop an integrated support equipment and systems that respond to the challenges and needs of these field that need to be addressed in an organized and integrated manner.

\section{MATERIALS AND METHODS}

\section{Operational and performance requirements for an integrated system}

The Emergency Assessment is the first phase with the following operating requirements:
A1. Collecting information from where events occurred: fires, explosions, industrial accidents, floods, etc.;

A2. Detection of the NBC contamination level of an area;

A3. Patrolling of some areas (border, communication routes, infrastructure - electrical networks, transport pipelines etc.) for the purpose of preventive detection of emergency situations or mapping duty in case of environments with changing topography.

On the basis of the collected data, it is possible to move to the second phase of efficient incidents management through:

B1. Persistent surveillance of the area where events occur that have a continuous spatial and temporal evolution (fires, floods, natural disasters, industrial accidents, etc.);

B2. Appropriate equipment for intervention staff with PPE tailored specifically to the event produced;

B3. Locating and tracking in real time intervention teams;

B4. Search for missing persons in natural environments covered with dense vegetation;

B5. Temporary provision of radio communication coverage of mobile radio communications networks in isolated/hard-to-reach areas or where terrestrial networks are unavailable/degraded;

B6. Small-scale logistics transport in remote areas.

\section{Component and capabilities of the integrated system support}

The conceptual block scheme of the integrated support system for emergency interventions is presented in figure 1.

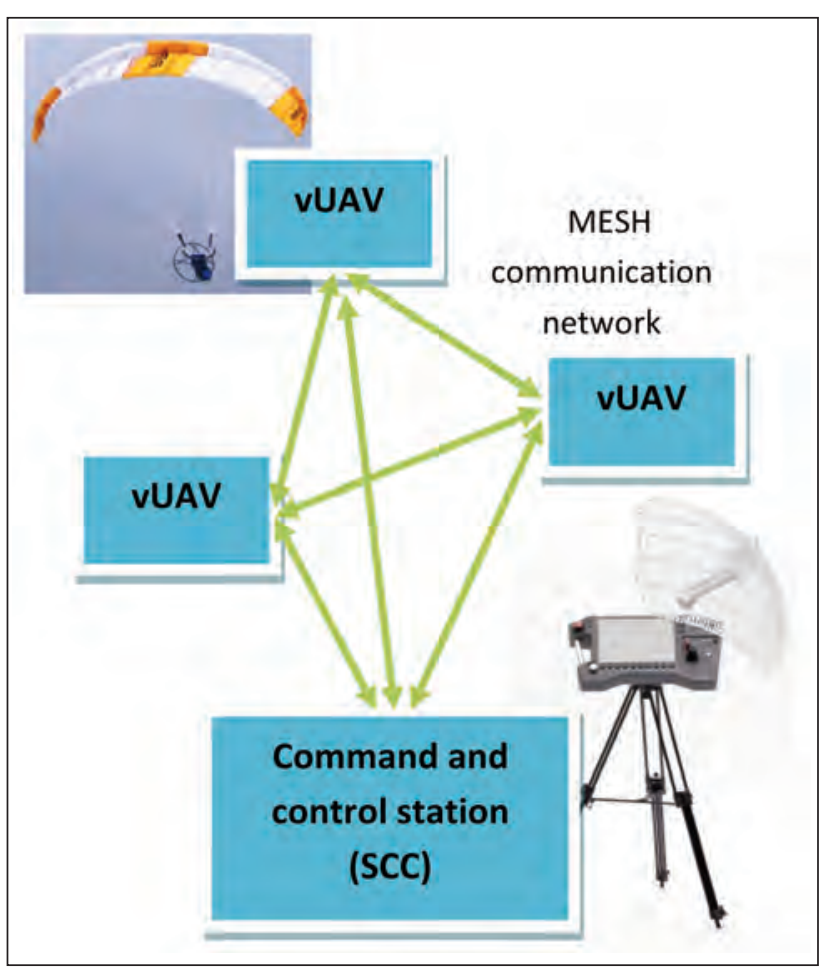

Fig. 1. The conceptual block scheme of the integrated support system for emergency interventions 
Component elements of the support system:

a) UAS vectors ( $V U A V$ )

Flexible wing type paraglider, with hybrid electric and/or thermic engine propulsion and interchangeable load [2-4]:

C1. Video stabilized support: HD day-night and/or FLIR (Forward Looking Infrared) camera and/or LiDAR (Light Detection and Ranging) sensor;

C2. NBC sensor suite including: gas detector and volatile organic compounds; ionizing radiation detector and aerosol sample collector;

C3. Detection and location unit for multiband and telecommunication relay in GSM band;

C4. Cargo unit.

b) Command and Control Station (SCC)

This station is used for controlling and monitoring the air vectors and transmitting the data in real time to the command point of the intervention and consists of: antennas (a fixed antenna and a tracking antenna); data transceiver; microcomputer; HID (Human Interface Devices); rechargeable battery and generator. Transmission of these data is encrypted by highspeed terrestrial data transmissions in the $5 \mathrm{GHz}$ or $4 G$ GSM band if there is no access to a terrestrial telecommunication hub.

From the analysis of the operational and performance requirements [5], the best wing configuration for the flight module is chosen to be a single skin ram-air paraglide (figure 2). This configuration significantly has less weight then the classic ram-air construction.

This type of flexible wing UAV has major cost advantages over a fixed wing UAV. A UAV with flexible wing does not have the flight speed of a fixed wing and cannot fly in a fixed position as a rotor type UAV. If we are to enumerate the pros/cons of a flexible wing UAV, they would look like this:

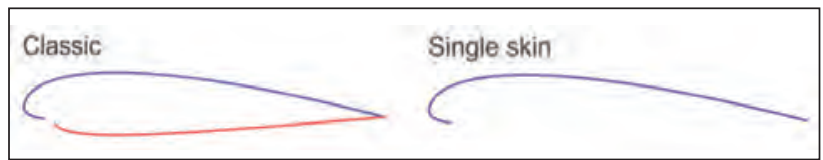

Fig. 2. Types of flexible wing profiles
Pros:

- Low cost;

- Low complexity;

- High reliability;

Cons:

- High cargo capacity.

- Low flight speed;

- Low flight dynamics;

- Weaknesses facing adverse climatic factors. The last disadvantage is to be minimized by developing a fabric that exhibits superior characteristics of resistance to adverse climatic factors: rain, heat and UV radiation.

\section{RESULTS AND DISCUSSION}

Figure 4 depicts a possible construction option for the primary UAV control module:

Main UAV vector features (vUAV):

- All up weight of the UAV vector: max. $50 \mathrm{~kg}$;

- Maximum payload: $30 \mathrm{~kg}$;

- Projected wing span [6]: $6.8 \mathrm{~m}$;

- Flight endurance:

- 1h (electric);

- 3h (internal tank ICE);

- $+12 \mathrm{~h}$ (external tank ICE).

- Speed: 25-65 km/h, $35 \mathrm{~km} / \mathrm{h}$ cruise speed;

- Dual electric/thermal propulsion:

- The experimental model powered by a small block two-stroke internal combustion engine of $>24$ cc ( 2.2 HP @ 9000 rpm) that drives the main propeller through a dog-clutch and a transmission belt;

- A starter-motor-generator (MG) also attached to the propeller shaft;

- The experimental model can be powered in three ways:

- ICE only;

- MG only;

- Powered by both engines (ICE + MG).

- Environmental operating conditions for any UAS vector:

- Temperature: $-30^{\circ} \mathrm{C}+50^{\circ} \mathrm{C}$;

- Altitude: <3000 m;

- Normal operation in rain, snow and dust conditions (> IP54).

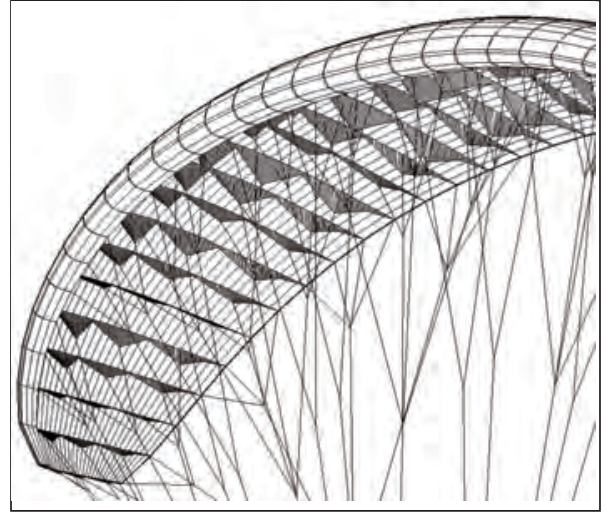

Fig. 3. Wing - single skin construction

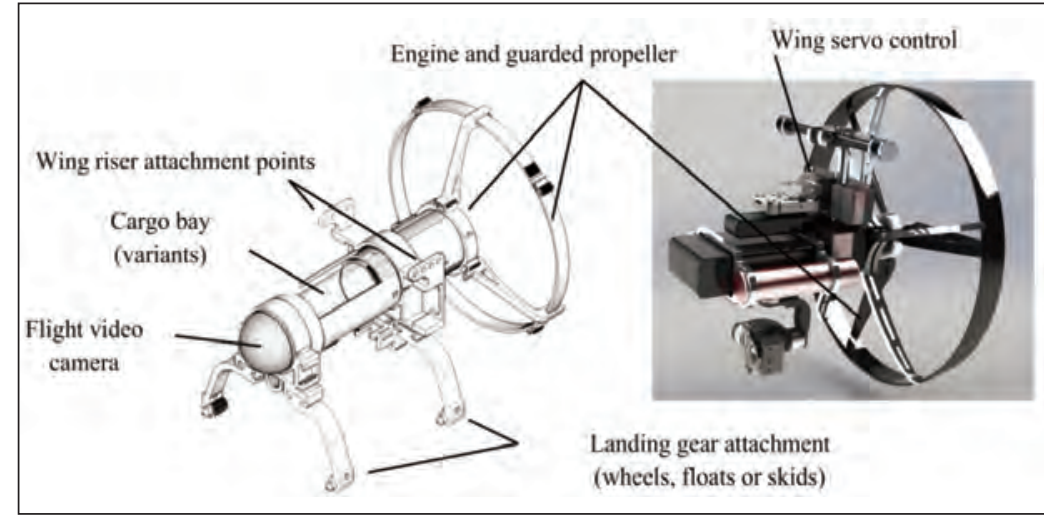

Fig. 4. Main UAV airframe and support structure 


\section{CONCLUSIONS}

The flexible ram-air wing will be a single skin ram-air glider with 6.8 meter projected wing span.

The fabric used in the manufacture of the wing has superior characteristics of resistance to adverse climatic factors: rain, heat and UV radiation. In particular double rip-stop nylon 6.6 fabrics with urethane amino modified poly siloxane coating for UV protection and plasma treatment for advanced hidrophobization.

The propulsion system will comprise of a small block internal combustion engine coupled thru a mechani- cal power selector to an electrical motor/generator and to the propeller.

The modular configuration of UAS support system and load variants of the UAS support system are:

- Video suite: permanently mounted (for observation, monitoring, cartography and GIS);

- NBC sensor set: if necessary (for investigation area, NBC hazard detection);

- Sensor detection and localization sensor set: if necessary (for locating missing persons, fire detection and wind direction detection);

- Cargo unit: if necessary (or emergency transport, medicines and supplies in remote areas, small cargo, up to $10 \mathrm{~kg}$ ).

\section{REFERENCES}

[1] Green, L.V., Kolesar, P.J., Improving emergency responsiveness with management science, In: Manage Sci, 2004, $50,8,1001-1014,173-187$

[2] Günaydin, K.G., Çeven, E.K., A research on tensile and abrasion properties of fabrics produced from conventional and fire resistant type polyester yarns, In: Industria Textila, 2017, 68, 6, 407-414, http://doi.org/10.35530/ IT.068.06.1484

[3] Mihai, C., Ene, A., Jipa, C., Ghimus, C.D., Structure with controllable permeability for vertical aerodynamic stabilizers-decelerators, In: Industria Textila, 2018, 69, 2, 146-151, http://doi.org/10.35530/IT.069.02.1530

[4] Mengüç, G.S., Temel, E., Bozdoğan, F., Sunlight exposure: the effects on the performance of paragliding fabric, In: Industria Textila, 2018, 69, 5, 381-389, http://doi.org/10.35530/IT.069.05.1406

[5] Knache, T.W., Parachute recovery systems - Design Manual, Para Publishing, Santa Barbara, California, 1992, 287288

[6] Poynter, D., The Parachute Manual - A Technical Treatise on Aerodynamic Decelerators, Vol. 2, Santa Barbara, California, 1984, 473

Authors:

ADRIAN SĂLIŞTEAN, DOINA TOMA, SABINA OLARU, CLAUDIA NICULESCU

INCDTP - National Research and Development Institute for Textile and Leather,

Lucretiu Patrascanu 16, 030508, Bucharest, Romania, office@incdtp.ro

Corresponding author:

ADRIAN SĂLIŞTEAN

e-mail: adrian.salistean@incdtp.ro 


\title{
Elaboration of a rest index for a sewing post in a clothing industry
}

DOI: $10.35530 / I T .070 .05 .1543$

AMIRA LAKHAL

YASSINE CHAABOUNI

NEJIB SEJRI

FADHEL JAAFAR

MORCHED CHEIKHROUHOU

\author{
ABSTRACT - REZUMAT
}

Elaboration of a rest index for a sewing post in a clothing industry

The textile industry of clothing causes professional diseases in particular the musculoskeletal disorders (MSDs). The application of the culture of technical ergonomics and the methods of ergonomic analysis is to reduce the risk of the diseases. The main objective of this study is to elaborate a rest index which allows giving a recovery period for the sewing post to reduce the risk of MSDs. The method of experimental designs is used to find a model which contains the parameters: the force multiplier, the frequency of technical actions per minute, the posture multiplier and the recovery period multiplier. Then the analysis of results was done by MINITAB Software. The method of General Sewing Data is used to analyze the gesture of the technical actions. The standard ISO 11228-3 is used to determine the posture analysis and the recovery period multiplier. Then, the force analysis is realized by the Borg Score. The model proposed is statistically significant ( $p$ value $=0$ ), representative $\left(R^{2}=96.5 \%\right)$ and validated according to the predictor Fisher test. The practical study was made in two companies of clothing to validate the rest index which varies between 1.14 and 1.22.

Keywords: MSDs, action, ergonomic, force, posture, recovery, time

Elaborarea unui indice de repaos pentru operatorul confecţioner în industria de îmbrăcăminte

Industria textilă şi de îmbrăcăminte provoacă boli profesionale, în special afecțiunile musculo-scheletice (MSD). Aplicarea culturii ergonomiei tehnice și a metodelor de analiză ergonomică se realizează pentru a reduce riscul bolilor. Obiectivul principal al acestui studiu este elaborarea unui indice de repaos, care să permită acordarea unei perioade de recuperare pentru operatorul confecţioner, pentru a reduce riscul de apariție a bolii. Metoda proiectărilor experimentale este utilizată pentru a găsi un model, care să conțină parametrii: multiplicatorul de forță, frecvența acțiunilor tehnice per minut, multiplicatorul de postură și multiplicatorul perioadei de recuperare. Analiza rezultatelor a fost realizată cu software-ul MINITAB. Metoda referitoare la Datele Generale privind Operația de asamblare a fost utilizată pentru a analiza activităţile tehnice. Standardul ISO 11228-3 a fost utilizat pentru a realiza analiza posturii și multiplicatorul perioadei de recuperare. Ulterior, analiza forței a fost realizată prin scorul Borg. Modelul propus este semnificativ din punct de vedere statistic (valoarea $p=0$ ), reprezentativ $\left(R^{2}=96,5 \%\right)$ și validat în conformitate cu testul Fisher predictor. Studiul practic a fost realizat în două companii producătoare de îmbrăcăminte pentru a valida indicele de repaos care variază între 1,14 și 1,22.

Cuvinte-cheie: MSD; acțiune, ergonomic, forță, postură, recuperare, timp

\section{INTRODUCTION}

The textile industry of clothing positions as pillar of Tunisian industry, keeps an important place in the national economy and support a strong contribution in the socioeconomic balances of Tunisia. The sector represents $26.6 \%$ of gross domestic product of Tunisia in 2015 [1]. But, the sector causes professional diseases in particular the musculoskeletal disorders (MSDs). The diseases of MSDs can be located at the level of the hand, the fingers and the wrists, at the level of the elbow, the shoulder, the neck, the back or still at the level of knee and the ankle [2-4]. The diseases of MSDs are connected to a large number of physical constraints (repetitive work, uncomfortable posture...) and psychology organizational (variable work, insecurity of employment...) [5]. The principal objective of this study is to evaluate a rest index to give for the sewing post a percentage of recovery time of the cycle time to minimize the risk of MSDs.

\section{MATERIAL \& METHODS}

The principal objective of this study is to find a model which allows determining a coefficient of rest for sewing post by using parameters chosen from an ergonomic study made according to the standard ISO 11228-3. The method of experimental designs was used to elaborate an index of rest [6]. The tests are determined by the following method:

Ergonomic Index =

$$
=1+\frac{\sum(\mathrm{FM}+\mathrm{FA}+\mathrm{PM}+\mathrm{REM}+\mathrm{RCM}+\mathrm{TM}+\mathrm{AM})}{100}
$$

Knowing that: $F_{M}$ is the force multiplier, $P_{M}$ - the posture multiplier, $R_{E M}$ - the repetitiveness multiplier, $R_{C M}$ - the recovery period multiplier, $T_{M}$ - the multiplier 
duration and $A_{M}$ - the additional multiplier. The variables parameters are $F_{M}, F_{A}, P_{M}$ and $R_{C M}$. The additional multiplier $A_{M}$ was fixed to 0,8 absolute precision and the rhythm is high for more than $80 \%$ of the cycle time [1]. The parameter "duration multiplier" was fixed to 0,5 since, the day time working is greater than 480 minutes for $68 \%$ of Tunisian companies applying more than 8 hour per day.

The cycle time for sewing task is generally greater than 15 seconds [1]. The repetitiveness multiplier was fixed to 1 according to the standard ISO 11228-3. The table 1 summarizes the modality of the different factors of this study.

Table 1

THE VARIOUS FACTORS AND THEIR MODALITY

\begin{tabular}{|l|c|c|}
\hline \multicolumn{1}{|c|}{ Factors } & Modality 1 (-) & Modality 2 (+) \\
\hline $\mathrm{F}_{\mathrm{M}}:$ the force multiplier & 0.5 & 1 \\
\hline $\begin{array}{l}\mathrm{F}_{\mathrm{A}}: \text { The frequency of } \\
\text { technical actions/minute }\end{array}$ & 30 actions/min & 60 actions/min \\
\hline $\begin{array}{l}\mathrm{P}_{\mathrm{M}}: \text { The posture } \\
\text { multiplier }\end{array}$ & 0.5 & 0.7 \\
\hline $\begin{array}{l}\mathrm{R}_{\mathrm{CM}}: \text { The recovery } \\
\text { period multiplier }\end{array}$ & 0.25 & 0.7 \\
\hline
\end{tabular}

The comprehensive method in fact a full factorial conception is selected where this type of plan exhaustive doing all possible combinations of input variable [6]. The value of factor $K$ equal to 4 and the number of level is two levels. The MINITAB software is used to analyze data by choosing the multiple linear regression models with the additive form [7].

$$
Y=b_{0}+\Sigma \beta_{i} X_{i}
$$

After the theoretical elaboration of the rest index, a practical study was made to validate this index for different articles for clothing and for technical uses. The study was realized in tow Tunisian sewing companies. Then, the tests are made in three chains whose two simple lines contain 36 workers and the third has 42 workers and the establishment I S-shaped. The working time in the companies is more than 480 minutes per day with more than 4 hours of working without a recovery period. The steps performed for each article are the following:

- A general observation of the swing posts;

- A gesture analysis according to a predetermined measurement method. The General Sewing Data method [8] was chosen to determine the cycle time and the technical actions of the left and right hands to determine the frequency of technical action per minute;

- A force analysis with the BORG score [9] to determine the force multiplier;

- A posture analysis at the elbow, hand and wrists to determine the posture multiplier;

- Determination of the recovery period multiplier according to the number of hours per day without recovery period according to the standard ISO 11228-3;

- Determination of the rest index according to the proposed model.

\section{RESULTS AND DISCUSSION}

The MINITAB software is used to analyze data, the regression equation is of the following form:

$$
\begin{gathered}
Y=1,27+0,00175 F_{A}-0,104 F_{M}- \\
-0,112 P_{M}-0,0833 R_{C M}
\end{gathered}
$$

According to the regression equation, it is indeed a multiple linear regression model [10-11] with a summation of linearity of different parameters with a constant equal to 1.27. The "p" value for the parameters that included in the model is very low. Therefore, all the coefficients are important in the regression model and are statistically significant. The standard deviation of model "S equal to 0.0098 " and the correlation coefficient " $\mathrm{R}^{2}$ equal to $96.5 \%$ ", while the error is equal to " $3.5 \%$ ", less than " $5 \%$ ". The values of the coefficient " $R$ " indicate that the model is better. As a conclusion, the calculated answers will be highly correlated with experimental answers. The value of " $\mathrm{R}^{2 \text { " }}$ is equal to $96.5 \%$, so, the quality of this model is better. In a hypothesis test, the decision can be based on the probability value "p value" [12-13]. In fact, if the value of " $p$ " is less than or equal to a predetermined level of significance (alpha $=0.05$ ), so the model is statistically significant. If not, we must reject the model. According to the model suggested " $\mathrm{P}=0$ ", so the model is statistically significant [4-13]. According to the model " $\mathrm{P}=0$ ", well observed that the "F statistic equal 75.23" is a significant value higher than "F critical $=3.357$ ", which satisfies the predictor Fischer test. The predictor Fischer test "HO" does not describe the variation of test results. The predictor Fischer test "F" gives an ideal probability "prob F" rejects the null hypothesis. Below " $5 \%$ ", the model cannot be rejected in this case; "prob $\mathrm{F}$ " is equal to "3.9\%". Therefore, the model is representative. Observing the interactions given by statistical analysis as shown in figure 1, there are no interactions between the overall input parameters.

Figure 2 indicates the effects of the variables over the response. In fact, the parameter "Frequency of technical actions/minute" has a positive effect over the response with a statistical coefficient equal to 0.00175 . However, the parameters "force multiplier", "posture multiplier" and "recovery period multiplier" have a negative effect over the response with the successively coefficient: "0.104"; "0.112" and "0.0833".

The practical study was realized for different articles for clothing and for technical uses, the table 2 shows the results.

Textile and clothing industry has been known for its incremental changes and the multiple organizational disruptive changes [16]. MSDs are a major health problem in the work place and especially in the clothing 


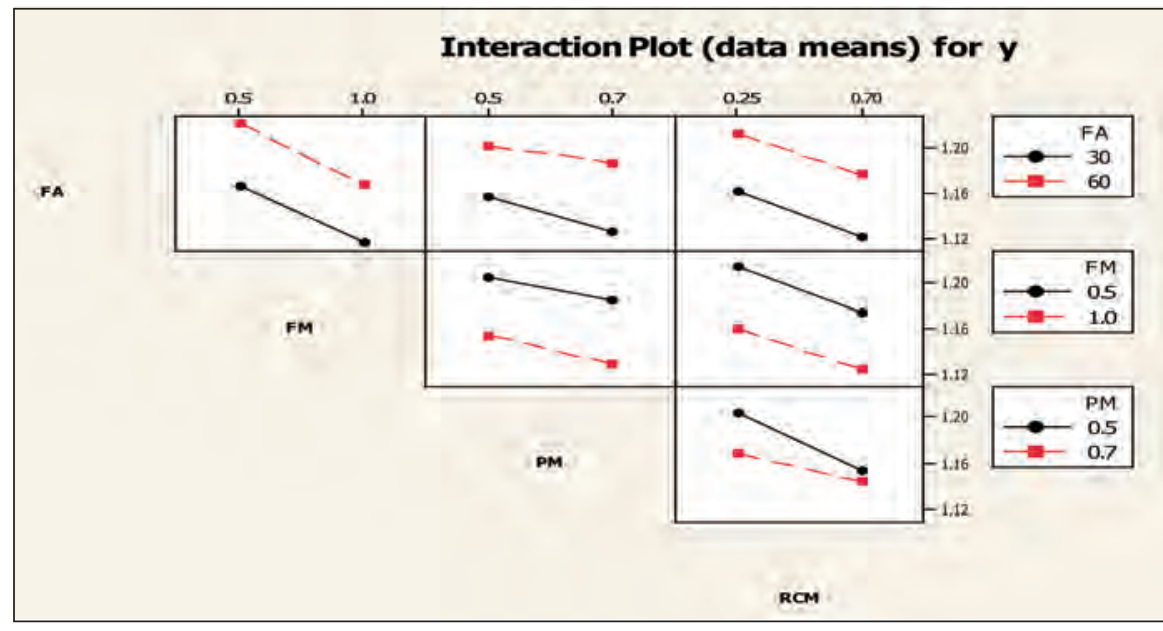

Fig. 1. Diagram of interaction Plot between the variables

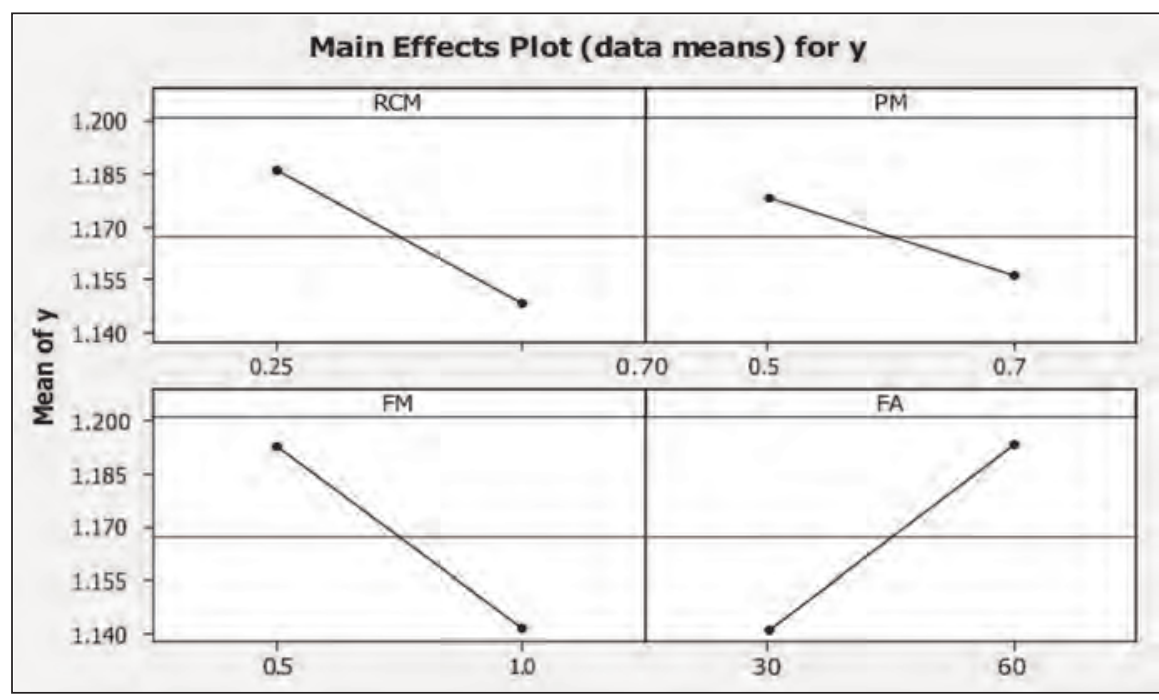

Fig. 2. Diagram of the principal effects of the variables over the rest index level competence required [4]. Then, the nature of the sewing machine usually requires a sitting posture and the assembly task requires pushed to the right and the left hand [7]. The analysis of sewing post shows that the MSDs are a major problem with $78 \%$ of the population has problems of the lower luck, $76 \%$ in the hands and wrists, $52 \%$ in the neck and $48 \%$ in the shoulders. The frequent use of two hands throughout the cycle of working for a stitching task increases the frequency of technical actions. The level of the force increases by the action of sewing in the cycle and by the use of the tools and the materials. The time of the cycle working and the duration of daily work in the company affected the risk of MSDs, as well as posture knowing that the stitching station is major cause for the risk [1].

According to these factors, a rest index has been developed which allows giving a recovery time for each post. This index is defined according to the following parameters; frequency of technical actions that varies according sector and represent the leading cause of occupational diseases. The major causes of MSDs are physical exertions, repetitive movements and awkward position [15]. Other causes of the MSDs diseases are related to the following factors that machine incidents, machine breakdown, the light rate of work and lack of autonomy, the level of concentration and the to the number of gestures of the left and right hands in the cycle of a stitching task. The second parameter is the level of force that depends on the complexity of the task and the used tools. The next parameter is the posture multiplier which is related only to the movements of the hands, wrists and elbows. The last parameter is the recovery multiplier which is related

APPLICATION OF THE REST INDEX IN TWO COMPANIES OF CLOTHING FOR DIFFERENT ARTICLES

\begin{tabular}{|l|l|c|c|c|c|c|c|c|}
\hline Companies & \multicolumn{1}{|c|}{ Articles } & $\begin{array}{c}\text { Number of } \\
\text { operations }\end{array}$ & $\begin{array}{c}\text { Total time } \\
\text { (s) }\end{array}$ & RcM & $\begin{array}{c}\text { Pm } \\
\text { (min-max) }\end{array}$ & $\begin{array}{c}\text { FA } \\
\text { (min-max) }\end{array}$ & $\begin{array}{c}\text { FM } \\
\text { (min-max) }\end{array}$ & $\begin{array}{c}\text { Rest index } \\
\text { (min-max) }\end{array}$ \\
\hline \multirow{2}{*}{ Companies 1} & Casual trousers & 45 & 1334 & 0.53 & $0.5-0.6$ & $32-70$ & $0.6-0.83$ & $1.14-1.22$ \\
\cline { 2 - 9 } & Men jacket & 61 & 2293.44 & 0.53 & $0.5-0.6$ & $32-63$ & $0.75-0.77$ & $1.14-1.19$ \\
\hline \multirow{5}{*}{ Companies 2 } & Sport trousers & 23 & 586.4 & 0.55 & $0.5-0.6$ & $35-57$ & $0.75-0.81$ & $1.14-1.18$ \\
\cline { 2 - 9 } & Support for broom & 10 & 366.86 & 0.55 & $0.5-0.6$ & $41-55$ & $0.75-0.8$ & $1.15-1.17$ \\
\cline { 2 - 9 } & BAG & 10 & 405.4 & 0.55 & $0.5-0.6$ & $39-61$ & $0.76-0.84$ & $1.15-1.18$ \\
\cline { 2 - 9 } & Guettre & 19 & 665.74 & 0.55 & $0.5-0.6$ & $41-56$ & $0.75-0.78$ & $1.15-1.18$ \\
\hline
\end{tabular}


to the break time of the work and which influences the work rate.

The rest index was developed based on these parameters in order to reduce the risk of MSDs for a stitching station. This index depends on the task, the equipment and the tools used and also on the company itself in terms of job organization and working time. The use of this index must be done by increasing this index by the cycle time of a stitching task to give a percentage of recovery time for the operator. The rest index is valid for stitching operations that have a cycle time greater than 15 s and a working time of more than 8 hours per day.

The practical application for the articles studied indicates that the index of rest varies between 1.14 and 1.22. This shows that it takes a markup between $14 \%$ and $22 \%$ of the cycle time to give a recovery time to the workforce.

The ergonomic indexes found (14\%-22\%) are quite high compared with the ergonomic index for the automotive field which varies according to the manufacturer between $7 \%$ and $10 \%$ [1]. Indeed the index of rest depends on the complexity of the task which influences the frequency of the technical actions of two hands. Where this frequency varies between 32 and 70 actions per minute depending on the operation to be performed and the phase of the operation; this means that a preparation operation requires fewer actions than a mounting phase. In addition, the number of pieces to be stitched and the size of pieces influenced the frequency of the technical actions and the time of the stitching operation [8]. The force multiplier $F_{M}$ varies between 0.6 and 0.81 , in fact, this level depends on the frequency of the technical actions, the percentage of technological time (sewing action) in the cycle and tools used such as the chisel. The posture multiplier $P_{M}$ varies between 0.5 and 0.6 depending on the position of the elbows, hands and handles and also according to the percentage of awkward position in the work cycle of a task. The recovery multiplier time $R_{C M}$ depends on the break time according to the company's timetable. In fact, according to the ISO 11228-3 standard, every 60 s requires 10 s of recovery to have a coefficient $R_{C M}$ equal to 1 . The recovery makes it possible to rest the upper limbs of the workforce in order to minimize the risk of MSDs.

\section{CONCLUSION}

Tunisian garment sector is the most providers of occupational diseases including MSDs, despite its importance in the economy sector. This study was done to determine a rest index used as a cycle time increase multiplier of an operation to give a percentage of recovery time to the workforce to minimize the risk of MSDs. The proposed index is statistically significant since the value of $R^{2}$ is 96.5 and the error is $4.5 \%$ indicating that the model is representative. Thus, the value of $F$ statistic corresponds to the predictor Fischer test. The practical application of the index in various article and following the results found, the index of rest varies from 1.14 to 1.22 . This variance mainly depends on the complicity of the task, the phase of the operation (preparation, mounting...), the size and number of pieces, the percentage of technological time in the cycle, the tools used, the posture and the work timetable and the break time set by the company.

The proposal of a rest index is a solution to minimize the risk of MSDs. As well as the application of the ergonomic culture on the technical scale is necessary in the garment industries using ergonomic analysis methods and applying the ergonomic design approach to take preventive measures to achieve the optimal layout Workstations allowing the best organization of the post with a comfortable posture to reduce the time constraints and improve working conditions and increase the productivity and thus reduce the risk of MSDs.

\section{REFERENCES}

[1] Lakhal, A., Sejri, N., Chaabouni, Y., Jaafar, F., Cheikhrouhou, M., Ergonomic analysis in a company of clothing and evaluation of an ergonomic index related to Msds, In: International Journal of Research and Reviews in Applied Sciences, 2017, 31, 2, 46-53

[2] Barbara, A., Diana, S., Monore, K., Lawrence, J., Work-related musculoskeletal disorders: Comparaison of data sources for surveillance, In: American Journal of Industrial Medicine, 1997, 31, 5, 600-608

[3] David, G.C, Ergonomic methods for assessing exposure to risk factors for work-related musculokeletal disorders, In: Ocuupational Medecine, 2005, 55, 3, 190-199

[4] Ghram, R., Fournier, C., Khalfallah, T., Francis, S., Analyse des facteurs socioculturels et survenue des troubles musculosquelettiques: le cas des couturières en Tunisie, In: Perspectives interdisciplinaires sur le travail et la santé, 2010, 1, 21, http://doi.org/10.4000/pistes.2459

[5] Aptel, M., Aublet-Cuvelier, A., Cnockert, J-C., Les troubles musculosquelettiques du membre supérieur liés au travail, In: Revue du Rhumatisme, 2002, 17, 3, 455-469

[6] Dominique, C., Plan d'expérience factoriels: construction et propriétés des fractions de plans, Springer-Verlag Berlin Heidelberg, $1^{\text {th }}$ Edition, Pays de l'Adour, France, 1996

[7] Halpern, C.A., Kenneth, D., Design and implantation of participatory ergonomics program for machine sewing tasks, In: International journal of industrial ergonomics, 1997, 20, 6, 429-440

[8] Lakhal, A., Sejri, N., Chaabouni, Y., Jaafar, F., Cheikhrouhou, M., Analysis of the Sewing Time in a Clothing Industry. In: Transylvanian Review, 2017, 27, 16, 3602-3610

industroำ textillă 2019, vol. 70, no. 5 
[9] Borg, G.A., Psycho-physical bases of perceived exertion, In: Medicine and Science in Sports and Exercise, 1982, $14,5,377-387$

[10] Douglas, C.M., Elizabet, A.P., Geoffey G.V., Introduction to linear regression, WILEY, $1^{\text {th }}$ Edition, Arizona, India, 2015

[11] Khedher, F., Jaouachi, B., Waste factor evaluation using theoretical and experimental jean pants consumptions, In: The Journal of The Textile Institute, 2014, 106, 4, 402-408

[12] Maatouk, I., Msahli, S., Zidi, M., Sakli, F., Numerical simulation of yarn bending: Statistical optimization, In: International Journal of Applied Research on Textile, 2015, 3,2, 49-59

[13] Romdhani, Z., Hamdaoui, M., Chebi, A., Jendoubi, M., Effect of paste properties as inkjet printing film and Mathematical Model to Follow the Kinetic of Wetting Phenomeno, In: Industria Textila, 2018, 69, 1, 65-74, http://doi.org/10.35530/IT.069.01.1366

[14] Daniel, J.B., Kristopher, J.P., Patrick, J.C., Computational tools for probing interactions in Multiple Linear Regression, Multilevel Modeling and Latent Curve Analysis, In: Journal of Educational and Behavioral Statistics, 2006, 31, 3, 437-448

[15] Julitta, S., Boschma., Monique, H.W., Henk., F. Vander., Molen., Use of ergonomic measures related to musculoskeletal complains among constinction workers: A 2-year follow-up study, In: Journal Elsevier, safety and health at work, 2015, 6, 2, 90-96

[16] Turdor, L., Change in Textile and Clothing Industry, In: Industria Textila, 69, 1, 37-43, http://doi.org/ 10.35530/IT.069.01.1449

\section{Authors:}

AMIRA LAKHAL, NEJIB SEJRI, FADHEL JAAFAR, YASSINE CHAABOUNI, MORCHED CHEIKHROUHOU

University of Monastir, Textile Engineering Laboratory of ISET KsarHellel, 5070, Monastir, Tunisia

Corresponding author:

AMIRA LAKHAL

e-mail: a_mira1987@live.fr 


\section{CASP methodology applied in adapted garments for adults and teenagers with spine deformity}

DOI: $10.35530 / I T .070 .05 .1619$

ANDREJ CUPAR
ZORAN STJEPANOVIČ
SABINA OLARU

\author{
GEORGETA POPESCU \\ ADRIAN SĂLIȘTEAN \\ ANDREJA RUDOLF
}

\section{ABSTRACT - REZUMAT}

CASP methodology applied in adapted garments for adults and teenagers with spine deformity

The goal of the research presented in this article is to investigate the applicability of the CASP (Curvature, Acceleration, Symmetry, Proportionality) methodology for adapted garments' pattern design for real cases of adults and teenagers with spine deformity. The current research is the result of a collaborative work of Slovenian and Romanian research teams with common expertise and background. The results obtained by applying CASP methodology on theoretical case studies showed that this methodology could be adequate for assuring the appropriate garment pattern designs for real persons with kyphosis. In this research, the design stages of adapted garments for adults and teenagers with spine deformity were presented by using the CASP evaluation of the back and virtual prototyping of garments. The results of the study confirmed that reconstruction process of the basic shirt/blouse pattern design improved the appearance and fit of the product to the body with spine deformity. Also, this paper brings contributions to garment design technology by $3 D$ scanning and virtual try-on, taking into account the body shapes of the users.

Keywords: spine deformity, CASP methodology, 3D scanning, simulation, adapted garments

\section{Metodologia CASP aplicată articolelor de îmbrăcăminte adaptate pentru adulți și adolescenți cu deformări ale coloanei vertebrale}

Scopul studiului prezentat în acest articol este de a cerceta aplicabilitatea metodologiei CASP (Curbură, Accelerare, Simetrie, Proporționalitate) pentru proiectarea tiparelor aferente articolelor de îmbrăcăminte adaptate pentru cazuri reale de adulți și adolescenți cu deformări ale coloanei vertebrale. Acest studiu este rezultatul unei colaborări a echipelor de cercetare din Slovenia și România, cu expertiză şi preocupări comune. Rezultatele obținute prin aplicarea metodologiei CASP pe studii de caz teoretice au arătat că această metodologie ar putea fi adecvată pentru proietarea tiparelor de îmbrăcăminte corespunzătoare pentru persoanele care suferă de cifoză. În acest studiu, etapele de proiectare a articolelor de îmbrăcăminte adaptate pentru adulți și adolescenți cu deformări ale coloanei vertebrale au fost prezentate prin utilizarea evaluării CASP a spatelui și prototiparea virtuală a îmbrăcămintei. Rezultatele studiului au confirmat că procesul de reconstrucție al modelului de bază al cămășii/bluzei a îmbunătățit aspectul și ajustarea produsului pe corpul cu deformare a coloanei vertebrale. De asemenea, această lucrare aduce contribuții la tehnologia de proiectare a îmbrăcămintei prin scanare 3D și probare virtuală, ținând cont de forma corpului utilizatorilor.

Cuvinte-cheie: deformări ale coloanei vertebrale, metodologia CASP, scanarea 3D, simulare, îmbrăcăminte adaptată

\section{INTRODUCTION}

Garments must respond to various quality requirements expressed by users. In this context, the dimensional and shape correspondence between the user's body and the garment is essential in order to ensure the normal state of comfort while wearing the product and at the same time is a decisive factor in the purchasing of the product by the user.

On the market, it is difficult to find clothes for people with non-standard body shapes. Furthermore, there are people with different spine deformities, who also need well-designed and well-fitted garments.

Spinal deformities may be the result of many conditions, such as congenital malformation of the spinal column, disorders of the neuromuscular system or trauma. They may be progressive in which case their severity increases with age, leading to restrictions of pulmonary growth, nerve function and heart pumping capacity [1].

Deformations of the spine in early childhood and the nat puberty can cause problems in the mature period, because in the early stages of development irregular spine curvatures can occur: kyphosis (excessive curvature of a larger or smaller part oft he spine - rounding of the upper back, also called round back, hunchback), lordosis (exaggerated forward curvature of the spine in the lumbar region-belly is bulging and protruding forward) or scoliosis(on one and/or the other side S-shaped curved part or the whole spine). The normal spine, when viewed from behind, appears straight throughout its entire length, whilst from the side, when observing the thoracic and lumbar part of the spine, there are two visible curvatures: a gentle rounding of the upper back from the shoulders to the bottom of the ribcage known as thoracic kyphosis 


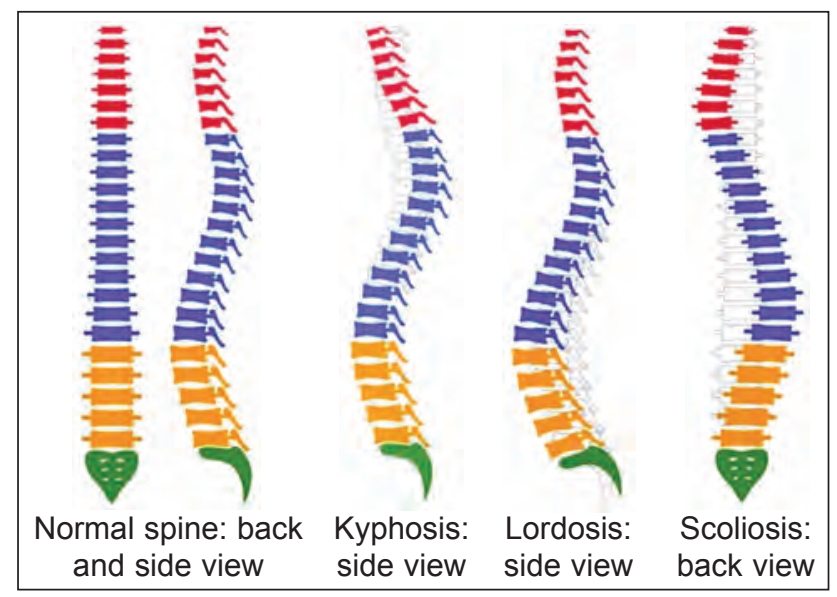

Fig. 1. Spinal deformity types [1]

and an opposite curve in the lower back known as lumbar lordosis. These two opposite curvatures of the spine are necessary in the normal spine to balance the trunk and head over the pelvis. A normal thoracic spine extends from the $1^{\text {st }}$ to the $12^{\text {th }}$ vertebra and should have a slight kyphosis ranging from $20^{\circ}$ to $45^{\circ}$ (figure 1). When the "roundness" of the upper spine increases past $45^{\circ}$ it is called "hyperkyphosis" [2].

Spine deformity has both physical and emotional implications. Especially at the age of adolescence, physical aspect is an important one, affecting even the integration of young persons into society.

Adolescence is the period of biological, psychological and social transition from puberty to adulthood, when people become more concerned about their own image and their position in relation to others. A great part of adolescent clothing styles are very close-fitted clothing products and therefore, should aesthetically fit humans' bodies. Appropriate garments that mitigate deficiencies and assures functionality, comfort and a general appearance contributes to mental health of the users. Thus, it is necessary to identify the conformational and posture changes and to study the ways to mask the defects, but to ensure the psycho-sensorial comfort. At the same time, care must be taken to ensure static and dynamic comfort, because some physical changes also involve changing the amplitude or direction of movement of the limbs or the body in general [3].

Adults and teenagers with sustained spine deformation have problems with clothes that do not fit well in the back and front parts. They are tight across the back, too short in the back length and too long in the front length, open at the back of the neck, hemlines can become uneven etc. [4].

Recent research works highlighted the complexity of 3D human body scan data modelling [5-9] and developed an interactive virtual try-on based three-dimensional garment block design for disabled people, especially of scoliosis type [10-12].

The results obtain by applying CASP methodology on theoretical case studies showed, that this methodology could be adequate for assuring the appropriate garment pattern design for real persons with curved kyphosis [13-15].

The main aim of this research is to investigate the applicability of the CASP (Curvature, Acceleration, Symmetry, Proportionality) methodology for adapted garments' pattern design for real cases of adults and teenagers with spine deformity. The current research is the result of collaborative work of Slovenian and Romanian research teams with common expertise and background.

\section{EXPERIMENTAL WORK}

\section{Scanning of studied teenagers using VITUS} SMART - HUMAN SOLUTIONS

The anthropometric survey developed by INCDTP in Romania among boys and girls aged 6-19 years [16], was conducted by using the mobile scanning system Vitus Smart with software Anthroscan of Human Solutions Group (figure 2). The equipment used to measure the children and teenagers was the threedimensional scanner (3D), constructed in accordance with EN ISO 20685:2005 "3-D scanning methodologies for internationally compatible anthropometric databases". Data acquisition on the human body shape and size was made in accordance with ISO 7250 "Basic human body measurements for technological design" and ISO 8559 "Garment construction and anthropometric surveys - Body dimensions". Therefore, 2900 children were scanned, of which were retained for statistical processing 1375 boys

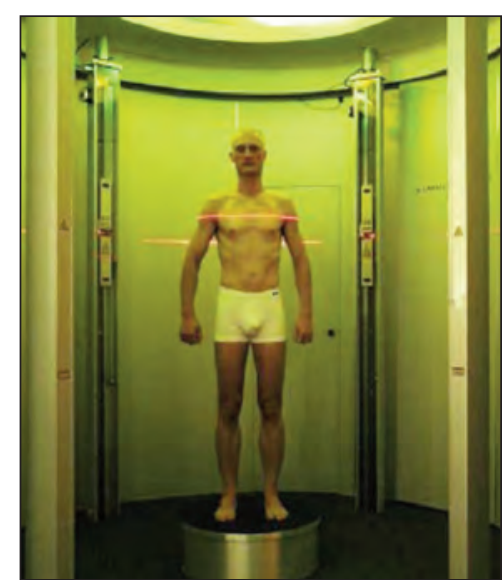

Fig. 2. Scanning system Vitus Smart and 1476 girls During the anthropometric survey, the research team met children with bodies that deviated from normality, both in terms of size as circumferences, lengths and widths and as proportions and body postures. The most common changes in conformation and posture were due to deficiencies in

the back, legs, uneven disposition of body fat etc.

From these cases, there have been selected two subjects with kyphosis: female teenager aged 18 years (TF1) and a male teenager aged 18 years (TM1) (figure 3).

These children and teenagers represent a category of wearers for that garments designed based on anthropometric standards are not conformable, requiring the design of customized patterns that take into account the conformational changes of posture and special needs. 


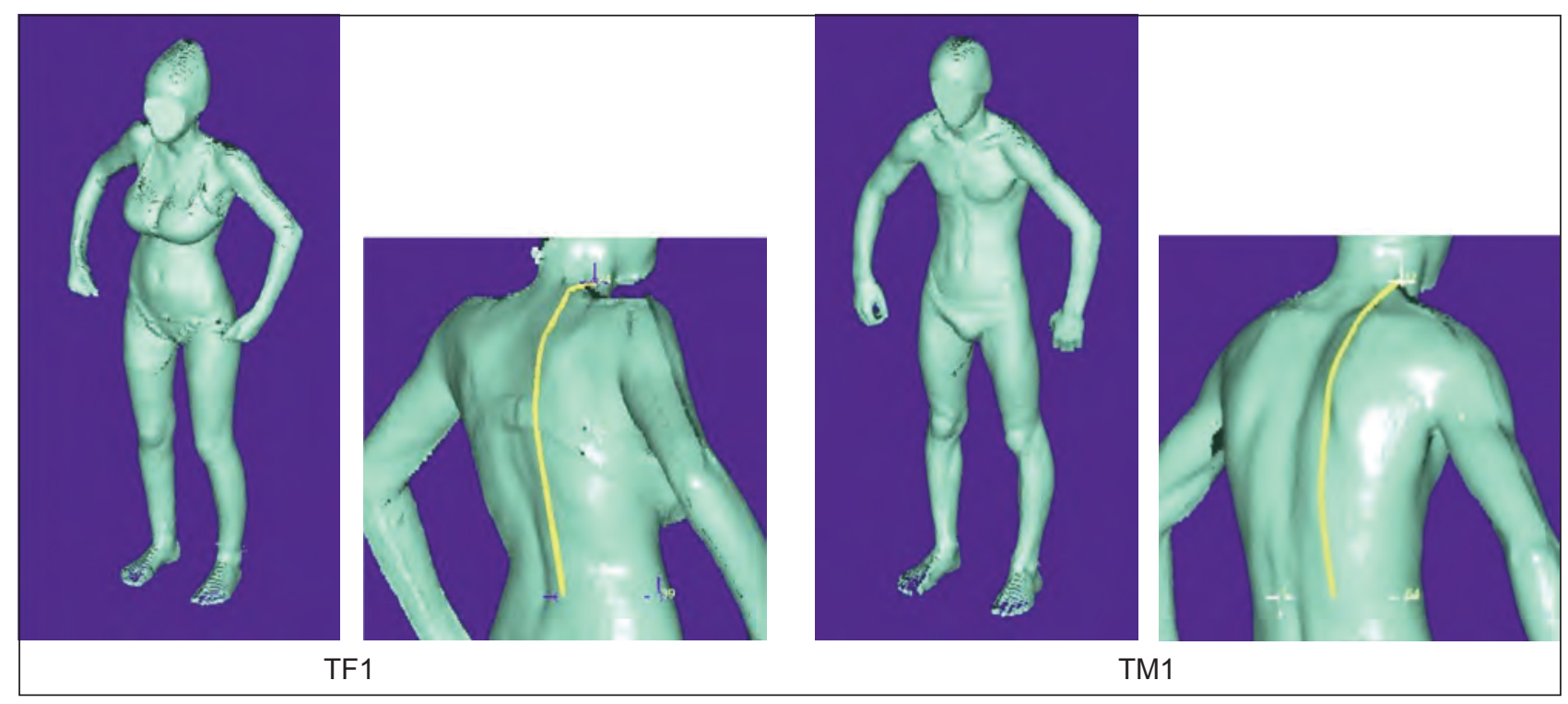

Fig. 3. Scanned bodies of the studied teenagers [16]

Scanning of studied adults using the HP 3D SCANER PRO

In this research, scanning of two Slovenian adults with kyphosis, female aged 40 years (TF2) and male aged 50 years (TM2) was performed using the HP 3D SCANER PRO optical scanning system for obtaining a standing 3D body model intended for virtual prototyping of the adapted garments [17].

3D scanner HP S3 (HP 3D SLS S3) is a structured light scanner (SLS). It is a general-purpose scanner intended for different engineering applications. According to the size of the product, which will be scanned several calibration panels are offered $30 \mathrm{~mm}$, $60 \mathrm{~mm}, 120 \mathrm{~mm}, 240 \mathrm{~mm}$ and $480 \mathrm{~mm}$. With the last one, the scanner's maximum measuring size is about $700 \mathrm{~mm}$, which is enough to scan the human upper body part, which was also in the focus in this research. That human body can be scanned with this general purpose scanner, a rotating platform was developed. During scanning, the scanner was static, whilst persons were rotated for every $45^{\circ}$ to scan the whole body around $360^{\circ}$. Tested persons had slightly upraised arms, breathing normally and wearing a tight undershirt during the scanning process.
Scanning with upraised arms was carried out for the purpose of the adapted garments' virtual prototyping [18]. Using the HP 3D SCANER PRO software separate scans were polygonised into one independent mesh (figure 4,a). Usually cleaning and manual alignment was required. Also, some smoothing and holes closing were done. This mesh can be finally exported. Further processing was done by using programs Blender and Gom Inspect in order to prepare the mesh with smoothing and manually adjusting and moving mesh under arms and other possible irregularities (figure $4, b$ ).

\section{The scanned bodies' dimensions and garments pattern design}

The virtual measurements of the scanned teenagers' bodies dimensions (TF1, TM1) were performed by using the Anthroscan software.

The female teenager (TF1) selected in this study represents a case of atypical development in the bust area, so the posture changes by bending the body to the anterior part. The garments with shoulder support for girls with these changes compared to those corresponding to their age group and height are uncomfortable, with the feeling of discomfort in the area of

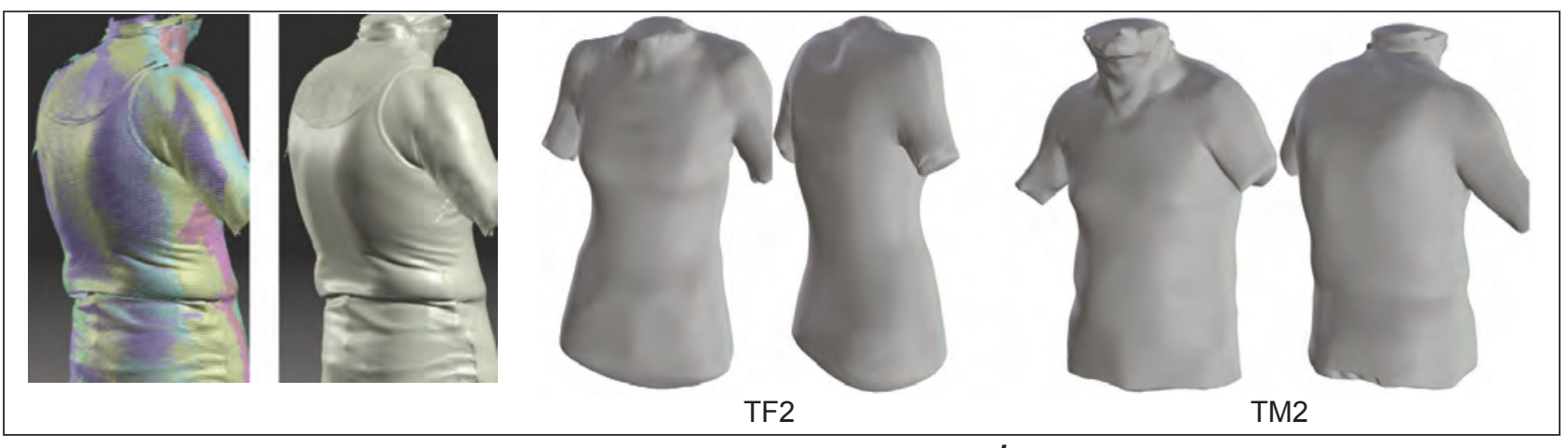

a

b

Fig. 4. Polygonised scans into: $a$ - one independent mesh; $b$-scanned bodies of the studied adults 
the bust and the appearance of unsightly folds in the area of the axle.

For the male teenager (TM1) selected in this study, the first step was to identify the area or areas with atypical modifications of conformation and posture. This is a case of changing of the posture through spine deformity, as can be seen in figure 3, the cervical area having a deflection to the anterior part and the torso shows a larger rounding than normal.

The anthropometric data needed to design the adapted blouse for the female teenager and the adapted shirt for the male teenager are collected in tables 1 and 2. The real anthropometric dimensions are compared with calculated proportional body dimensions (armscye depth, back length, hips depth, breast/chest width, armscye width, back width, front length, neck width). Among these proportional dimensions, the breast/chest width, armscye width, back width and neck width were only calculated. The determination of the anthropometric data was performed according to the ISO 8559 [19], whilst the proportional equations was used according to the construction system M. Müller\&Sohn [20-21]. The adult tested persons, the female (TF2) and male (TM2) represent a case of posture resembling kyphosis. The determination of the anthropometric data and used proportional equations for comparison of the virtually measured bodies dimension with calculated proportional dimensions were carried out according to the same standards as for the teenagers. In addition, dimensions of adults were measured virtually using the Optitex PDS 3D software tool. The anthropometric data needed to design the adapted blouse and shirt for adults are collected in tables 3 and 4.

For garments pattern design we have used the software program Optitex PDS and its module 3D for virtual prototyping of garments and evaluation of garment fitting to 3D bodies models. The functionalities work well for patterns, intended for garments for people without body deformations. In cases, related to the pattern design of adapted garments for people with body deformations, such as those seen in bodies with kyphosis, we need to apply a scanned 3D body model of the individual person instead of a standard 3D body model and perform additional analyses. Namely, the commercial PDS packages do not offer functionalities for supporting special requirements for adoption of 3D body models to different postures. Therefore, scanned 3D bodies models of teenagers and adults were imported into the Optitex PDS 3D. The basic pattern designs of blouses and shirts without sleeves and waist darts were constructed according to measured bodies dimensions and needed calculated proportional dimensions

Table 1

\begin{tabular}{|c|c|c|c|c|}
\hline \multicolumn{5}{|c|}{ SYNTHESIZING THE DATA FOR THE STUDIED PERSON TF1 } \\
\hline $\begin{array}{l}\text { Anthropometric } \\
\text { dimensions }\end{array}$ & Abbr. & $\begin{array}{c}\text { Measured body } \\
\text { dimensions } \\
(\mathrm{cm})\end{array}$ & $\begin{array}{l}\text { Calc. of prop. } \\
\text { body dimensions }\end{array}$ & $\begin{array}{l}\text { Calculated } \\
\text { body dimen. } \\
(\mathrm{cm})\end{array}$ \\
\hline Body height & $\mathrm{BH}$ & 163.0 & & \\
\hline Breast/Chest girth & BG & 91.0 & & \\
\hline Waist girth & WG & 68.5 & & \\
\hline Hips girth & HG & 87.0 & & \\
\hline Armscye depth & $A D$ & $23.0(+4.0)$ & $1 / 10 \mathrm{BG}+10.5 \mathrm{~cm}$ & 19.0 \\
\hline Back length & $\mathrm{BL}$ & $\begin{array}{c}40.0(0.0) \\
\text { over the blades } \\
43.0(+3.0)\end{array}$ & $1 / 4 \mathrm{BH}-1.0 \mathrm{~cm}$ & 40.0 \\
\hline Hips depth & HD & $59.0(-2.0)$ & $3 / 8 \mathrm{BH}$ & 61.0 \\
\hline Breast/Chest width & BW & & $1 / 4 \mathrm{BG}-4.0 \mathrm{~cm}$ & 17.2 \\
\hline Armscye width & AW & & $1 / 8 \mathrm{BG}-1.5 \mathrm{~cm}$ & 9.2 \\
\hline Back width & BW & & $1 / 8 \mathrm{BG}+5.5 \mathrm{~cm}$ & 16.1 \\
\hline Front length & $\mathrm{FL}$ & $43.0(-1.0)$ & $\mathrm{BL}+4.0 \mathrm{~cm}$ & 44.0 \\
\hline Neck width & NW & & $1 / 20 \mathrm{BG}+2.0 \mathrm{~cm}$ & 6.5 \\
\hline Shoulders length & SL & 13.0 & & \\
\hline
\end{tabular}

Table 2

\begin{tabular}{|c|c|c|c|c|}
\hline \multicolumn{5}{|c|}{ SYNTHESIZING THE DATA FOR THE STUDIED PERSON TM1 } \\
\hline $\begin{array}{l}\text { Anthropometric } \\
\text { dimensions }\end{array}$ & Abbr. & \begin{tabular}{|c|}
$\begin{array}{c}\text { Measured body } \\
\text { dimensions } \\
(\mathrm{cm})\end{array}$ \\
\end{tabular} & $\begin{array}{l}\text { Calc. of prop. } \\
\text { body dimensions }\end{array}$ & $\begin{array}{c}\text { Calculated } \\
\text { body dimen. } \\
(\mathrm{cm})\end{array}$ \\
\hline Body height & $\mathrm{BH}$ & 177.0 & & \\
\hline Neck girth & NG & 42.0 & & \\
\hline Breast/Chest girth & CG & 85.0 & & \\
\hline Waist girth & WG & 74.0 & & \\
\hline Hips girth & HG & 90.0 & & \\
\hline Armscye depth & $A D$ & $24.0(+3.5)$ & $1 / 10 \mathrm{CG}+12.0 \mathrm{~cm}$ & 20.5 \\
\hline Back length & $\mathrm{BL}$ & $\begin{array}{c}44.0(-4.0) \\
\text { over the blades } \\
48.0(0.0)\end{array}$ & $1 / 4 \mathrm{BH}+2.0 \mathrm{~cm}$ & 48.0 \\
\hline Breast/Chest width & $\mathrm{CW}$ & & $2 / 10 \mathrm{CG}-1.0 \mathrm{~cm}$ & 16.0 \\
\hline Armscye width & AW & & $1 / 10 \mathrm{CG}+2.0 \mathrm{~cm}$ & 10.5 \\
\hline Back width & BW & & $2 / 10 \mathrm{CG}-1.0 \mathrm{~cm}$ & 16.0 \\
\hline Chest length & $\mathrm{CL}$ & $22.0(+2.5)$ & $A D-1.0 \mathrm{~cm}$ & 19.5 \\
\hline Neck width & NW & & $1 / 6 \mathrm{NG}$ & 7.0 \\
\hline Shoulders length & $\mathrm{SL}$ & 15.0 & & \\
\hline
\end{tabular}



struction system M. Müller \& Sohn [20, 21]. Reasons for this are greater differences between the calculated and measured body dimensions (AD, BL, HD, FL, $\mathrm{CL}$ ), which can be seen in tables 1-4. These differences were expected, especially for the back length, armscye depth, front of chest length. All garments were constructed with $3.0 \mathrm{~cm}$ ease allowances in the breast/chest girth, waist girth and hips girth. Virtual simulations of garments were carried out with the aim to analyse garments fitting to $3 \mathrm{D}$ bodies models. The waist darts were released on females' blouses in order to avoid the tensions that would result from
(BW/CW, AW, BW, NW) by using rules of the con-

them (each stitch causes tension) and to divert attention when assessing the fit of clothing in the upper spine with the Tension tool of the Optitex PDS 3D program.

\section{CASP methodology to study teenagers and adults' upper back}

The CASP (Curvature, Acceleration, Symmetry, Proportionality) methodology was originally developed as a method for classification of perceptual surfaces and for analysing digital geometry [22]. Methodology of surface evaluation was developed to establish the meta-language in design communication, which was perceived as

Table 3 necessary part of styling. The

\begin{tabular}{|l|c|c|c|c|}
\hline \multicolumn{5}{|c|}{ SYNTHESIZING THE DATA FOR THE STUDIED PERSON TF2 } \\
\hline $\begin{array}{c}\text { Anthropometric } \\
\text { dimensions }\end{array}$ & Abbr. & $\begin{array}{c}\text { Measured body } \\
\text { dimensions } \\
\text { (cm) }\end{array}$ & $\begin{array}{c}\text { Calc. of prop. } \\
\text { body dimensions }\end{array}$ & $\begin{array}{c}\text { Calculated } \\
\text { body dimen. } \\
\text { (cm) }\end{array}$ \\
\hline Body height & BH & 168.0 & & \\
\hline Breast/Chest girth & BG & 76.0 & & \\
\hline Waist girth & WG & 62.0 & & \\
\hline Hips girth & HG & 82.0 & & 18.5 \\
\hline Armscye depth & AD & $22.0(+1.5)$ & $1 / 10 \mathrm{BG}+10.5 \mathrm{~cm}$ & 41.0 \\
\hline Back length & BL & $36.5(-4.5)$ & $1 / 4 \mathrm{BH}-1.0 \mathrm{~cm}$ & 63.0 \\
\hline Hips depth & $\mathrm{HD}$ & $54.0(-9.0)$ & $3 / 8 \mathrm{BH}$ & 15.0 \\
\hline Breast/Chest width & $\mathrm{BW}$ & & $1 / 4 \mathrm{BG}-4.0 \mathrm{~cm}$ & 8.0 \\
\hline Armscye width & $\mathrm{AW}$ & & $1 / 8 \mathrm{BG}-1.5 \mathrm{~cm}$ & 8.0 \\
\hline Back width & $\mathrm{BW}$ & & $1 / 8 \mathrm{BG}+5.5 \mathrm{~cm}$ & 15.0 \\
\hline Front length & $\mathrm{FL}$ & $38.0(-7.0)$ & $\mathrm{BL}+4.0 \mathrm{~cm}$ & 45.0 \\
\hline Neck width & $\mathrm{NW}$ & & $1 / 20 \mathrm{BG}+2.0 \mathrm{~cm}$ & 6.0 \\
\hline Shoulders length & $\mathrm{SL}$ & 8.5 & & \\
\hline
\end{tabular}

Table 4

SYNTHESIZING THE DATA FOR THE STUDIED PERSON TM2

\begin{tabular}{|l|c|c|c|c|}
\hline $\begin{array}{c}\text { Anthropometric } \\
\text { dimensions }\end{array}$ & Abbr. & $\begin{array}{c}\text { Measured body } \\
\text { dimensions } \\
\text { (cm) }\end{array}$ & $\begin{array}{c}\text { Calc. of prop. } \\
\text { body dimensions }\end{array}$ & $\begin{array}{c}\text { Calculated } \\
\text { body dimen. } \\
\text { (cm) }\end{array}$ \\
\hline Body height & BH & 172.0 & & \\
\hline Neck girth & NG & 46.0 & & \\
\hline Breast/Chest girth & CG & 101.0 & & \\
\hline Waist girth & WG & 93.5 & & \\
\hline Hips girth & HG & 100.0 & & \\
\hline Armscye depth & AD & $32.0(+10.0)$ & $1 / 10 \mathrm{CG}+12.0 \mathrm{~cm}$ & 22.0 \\
\hline Back length & $\mathrm{BL}$ & $49.0(+4.0)$ & $1 / 4 \mathrm{BH}+2.0 \mathrm{~cm}$ & 45.0 \\
\hline Breast/Chest width & $\mathrm{CW}$ & & $2 / 10 \mathrm{CG}-1.0 \mathrm{~cm}$ & 19.0 \\
\hline Armscye width & $\mathrm{AW}$ & & $1 / 10 \mathrm{CG}+2.0 \mathrm{~cm}$ & 12.5 \\
\hline Back width & $\mathrm{BW}$ & & $2 / 10 \mathrm{CG}-1.0 \mathrm{~cm}$ & 19.0 \\
\hline Chest length & $\mathrm{CL}$ & $25.0(+4.0)$ & $\mathrm{AD}-1.0 \mathrm{~cm}$ & 21.0 \\
\hline Neck width & $\mathrm{NW}$ & & $1 / 6 \mathrm{NG}$ & 8.0 \\
\hline Shoulders length & $\mathrm{SL}$ & 12.0 & & \\
\hline
\end{tabular}
first step was the analysis of existing geometry and the second a synthesis of newly created geometry considering the desired property. Four properties, which characterize surfaces similar as colours in colour space [23], where each colour is represented as a mix of values $L^{*}$, $a^{*}$ and $b^{*}$. The surface's geometrical space consists of these four properties: Curvature - C, Acceleration $A$, Symmetry - S and Proportionality - P. In addition, it was found out that CASP methodology is suitable for the purpose of analysis of the deformed areas of a human's body and adapted garment's pattern design for people with scoliosis and kyphosis [13-15]. In this research, the CASP methodology was applied on real bodies with spine deformity, mainly to evaluate the degree of curvature and symmetry of the upper spine or the roundback. All the studied subject, adults and teenagers, presented in figures 3 and 4 , were analyzed in the roundback area by using the CASP methodology (figure 5). The observation plane was projected on an imported body mesh model. The area of the observation plane was defined according to the acromion points and waistline, and shoulder width and waist width, respectively. The observed area was corrected with offset of $3 \mathrm{~cm}$ to the inside to avoid that the procedure vector misses the scanned mesh (figure 5). Further calculations were executed using the Grasshopper's 


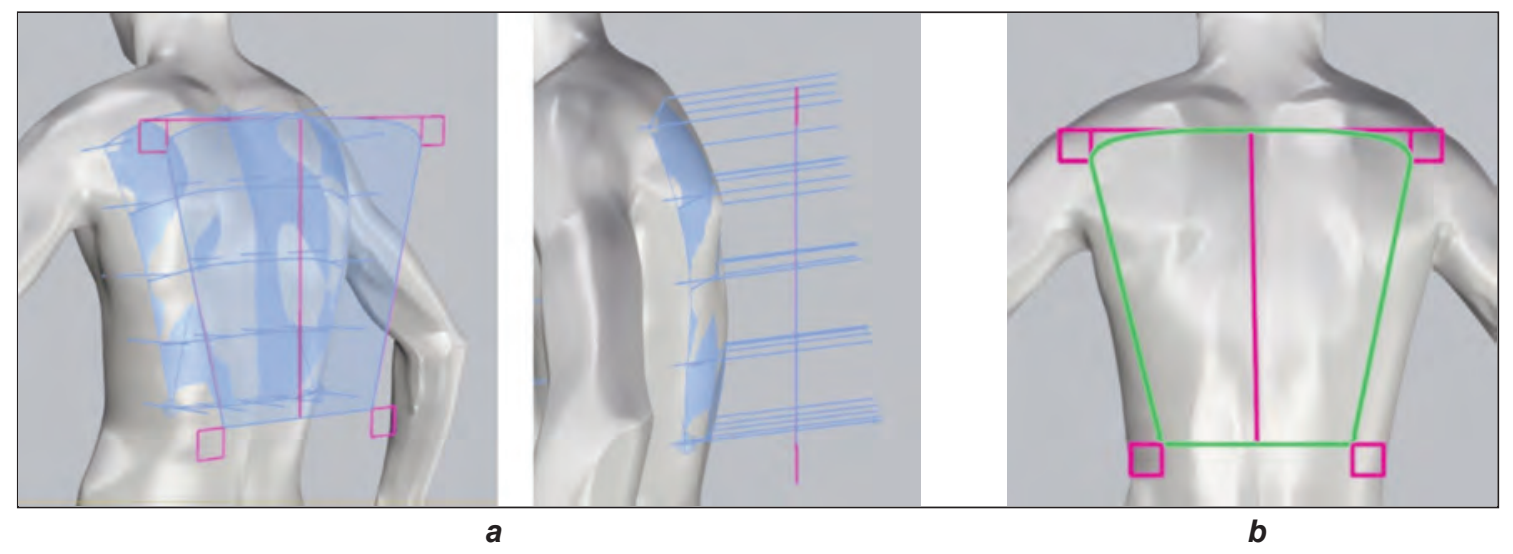

Fig. 5. Using the CASP methodology for:

$a$ - the roundback area analysis; $b$ - corrected area of $3 \mathrm{~cm}$ to the inside

nxn procedure. Values for CASP were obtained as numerical result. In addition, analysis of the CASP values and $3 \mathrm{D}$ bodies models' postures were carried out in order to find out if there is any connection between the CASP values and spine deformities that can be implemented into the garments basic pattern designs' adaptions with the aim to improve the garments' fitting to the bodies and to increase the wearing comfort. Namely, to the extent that CASP values allow us to more easily adapt a garment to a person with spinal deformity, such an analysis is much simpler than the method of observing the body, since the clients for whom we make custom-made garments usually do not undress to their underwear (a tight tshirt).

\section{RESULTS AND DISCUSSION}

\section{Analysis of garments' fitting to 3D bodies models}

The virtual fitting of the basic blouses and shirts pattern designs designed for standard bodies' postures without deformation of the spines are shown in figures 6 and 7. For both female tested persons (TF1, TF2) a good fitting of the blouses to bodies on the front parts can be seen, while the fit is worse on the back (figure $6, a$ ). This is especially pronounced for the test person TF1 with strong breasts, which may result from a greater curvature of the spine in the waist region (figure $6, b$ ). The reason for worse fitting of the blouse on the back is waist darts, which were released during construction. When observing the tension in the garments, greater tension in breasts' girths region is evident, especially for the female teenager (TF1) with strong breasts (figure 6,c). Therefore, it can be assumed that the weight of the breasts can be cause of a curvature of the shoulder blades' upper part, resulting in a tension of the back armhole and shoulder seam. The latter indicates that for persons with strong breasts a greater ease allowance should be added for greater wearing comfort (we have added $3 \mathrm{~cm}$ ), especially on the chest width and the armscye width. When comparing a female teenager and an adult, it can be seen that the adult TF2 has a curved entire upper part of the spine, which is characteristic for kyphosis, reflecting the transverse lines of tension (green) on the upper and lower shoulder blades parts. This is probably also the cause of the higher average tension of the garment in relation to the body, which is for an adult TF2 of 11.54 $\mathrm{fg} / \mathrm{cm}$ and a teenager TF1 of $7.42 \mathrm{fg} / \mathrm{cm}$, measured with a.

For both male tested persons (TM1, TM2) a good fitting of the shirt to bodies on the front parts can be seen, while the fit is worse on the back for the teenager TM1 in the neck area, where wrinkling of the neckline arose (figure 7,a). During the scanning the arms position caused tightening of the shoulder blades, which resulted in natural wrinkling of the shirt neckline (figure $7, b$ ). Therefore, any shirt reconstruction was not needed in this area. Evident tension in the area of shoulder blades, because of a typical spine kyphosis can be seen when observing the shirts' tension in relation to the body on the back parts of both tested persons (figure 7,c). For both tested persons TM1 and TM2, we assume that the seam of the shoulder strap is in the wrong position, which contributes to the tension. In addition, the volume of the shirt in the shoulder blades area needs to be increased to reduce the tension of that area on the body. An average tension of the shirt in relation to the body is for an adult TM2 $8.65 \mathrm{fg} / \mathrm{cm}$ and for a teenager TM1 $5.77 \mathrm{fg} / \mathrm{cm}$, also measured by using a Tension tool of the program Optitex PDS 3D.

\section{CASP and scanned persons' postures analysis}

The results of the CASP evaluation of the posterior body area (figure 5) are collected in table 5 . In the previous research regarding the CASP evaluation of the synthetic 3D body model with differently curved kyphotic spines it was found that, especially Curvature $-C$ and Acceleration - $A$ increase with an increase in the spine deformation and parameter $\mathrm{C}$ was used in the garment's reconstruction procedure to enhance the wearing comfort [14]. In this research, the real 3D scanned bodies were evaluated [24]. 


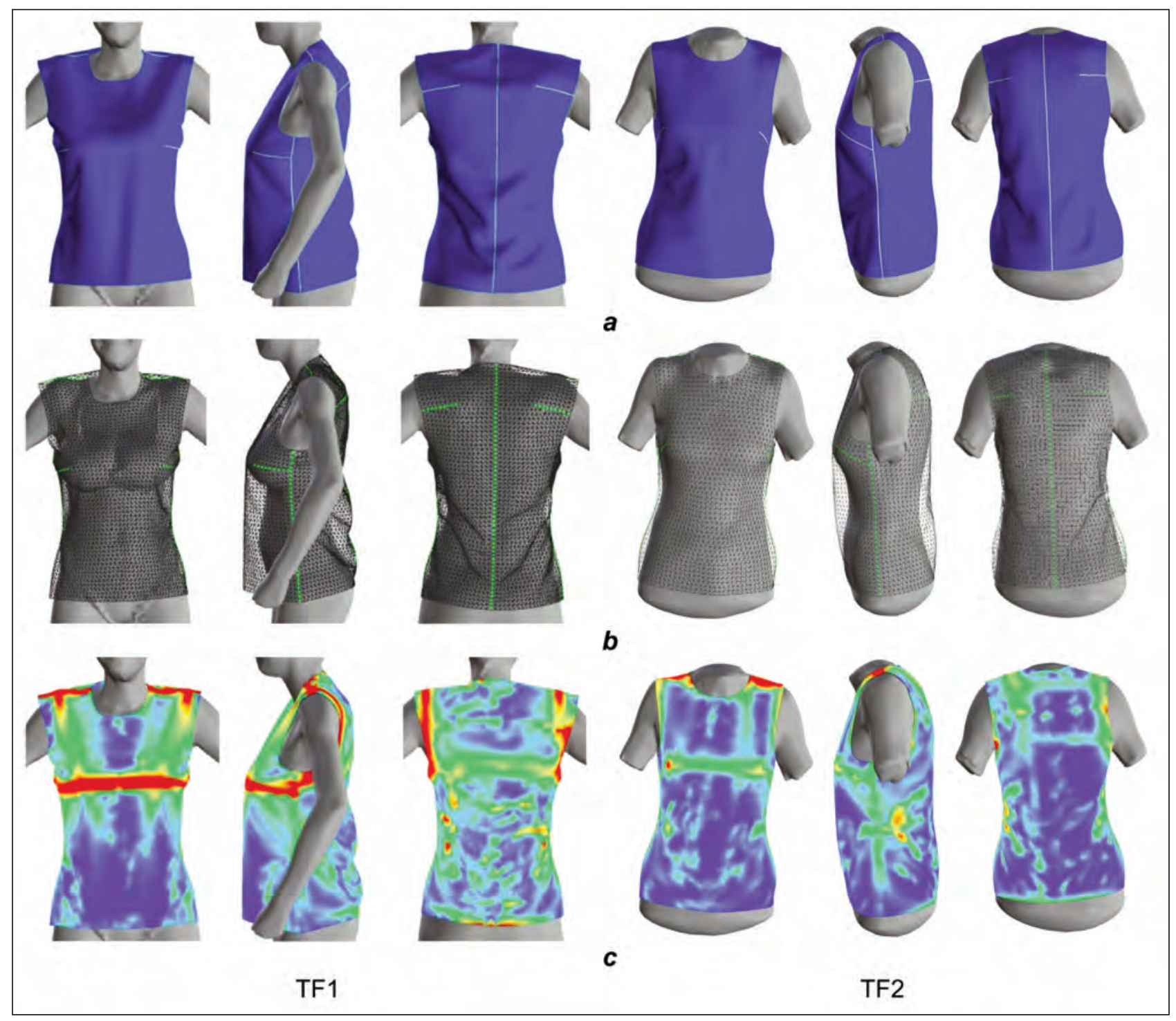

Fig. 6. Virtual fitting of the sleeveless basic blouses pattern designs to TF1 and TF2

Curvature is positive for surfaces where normal vectors dissipate and negative where vectors congregate. For our observed regions, the curvature is expected to be positive. Acceleration is a surface property, which describes if the observed surface has more curviness in the first or in the last half. Symmetry is an obvious property and equals to zero at perfect symmetry. For higher numbers the surface is less symmetrical. Proportionality indicates the ratio between height and width of the observed area. Properties $A$ and $P$ are not mandatory for this research.

The results of the parameter $\mathrm{C}$ show the highest curvature of the spine for both male tested persons TM2 (8.13) and TM1 (6.87) and lower for the female tested persons TF2 (6.54) and TF1 (6.25) (table 5). Both adults, female and male, have higher $\mathrm{C}$ parameter values than teenage female and male, meaning a potentially more pronounced kyphotic spine. The shape and curvature of the spine shown in figure 8 indicate that the adult test subjects TM2 (8.13) and
TF2 (6.54) have greater kyphosis deformity than teens TM1 (6.87) and TF1 (6.25). Therefore, we believe that the value of parameter $C$ can be reliably included in the process of reconstruction of the garment as predicted in the study [14]. We can also see a smaller scoliosis for both female tested subjects TF1 and TF2 and possibly lordosis of the female teenager TF1 (figure 8). More visible scoliosis shows the teenager female person TF1, which also indicates the highest parameter $\mathrm{S}$ of 56.28 (table 5, figure 8). In addition, pronounced blades are the result of arms postures while scanning the teens. The female teenager probably does not have kyphosis but curves the shoulder area because of strong breasts. Therefore, we had focused in continuation on clothes customization to increased wearing comfort for the TF1 test person in the breasts area and for other tested persons in kyphotic area. Both adults have similar asymmetry and parameter $S$ at about 20, respectively. Asymmetry could be also caused by posture during the scanning process. It can be concluded that the higher value of 


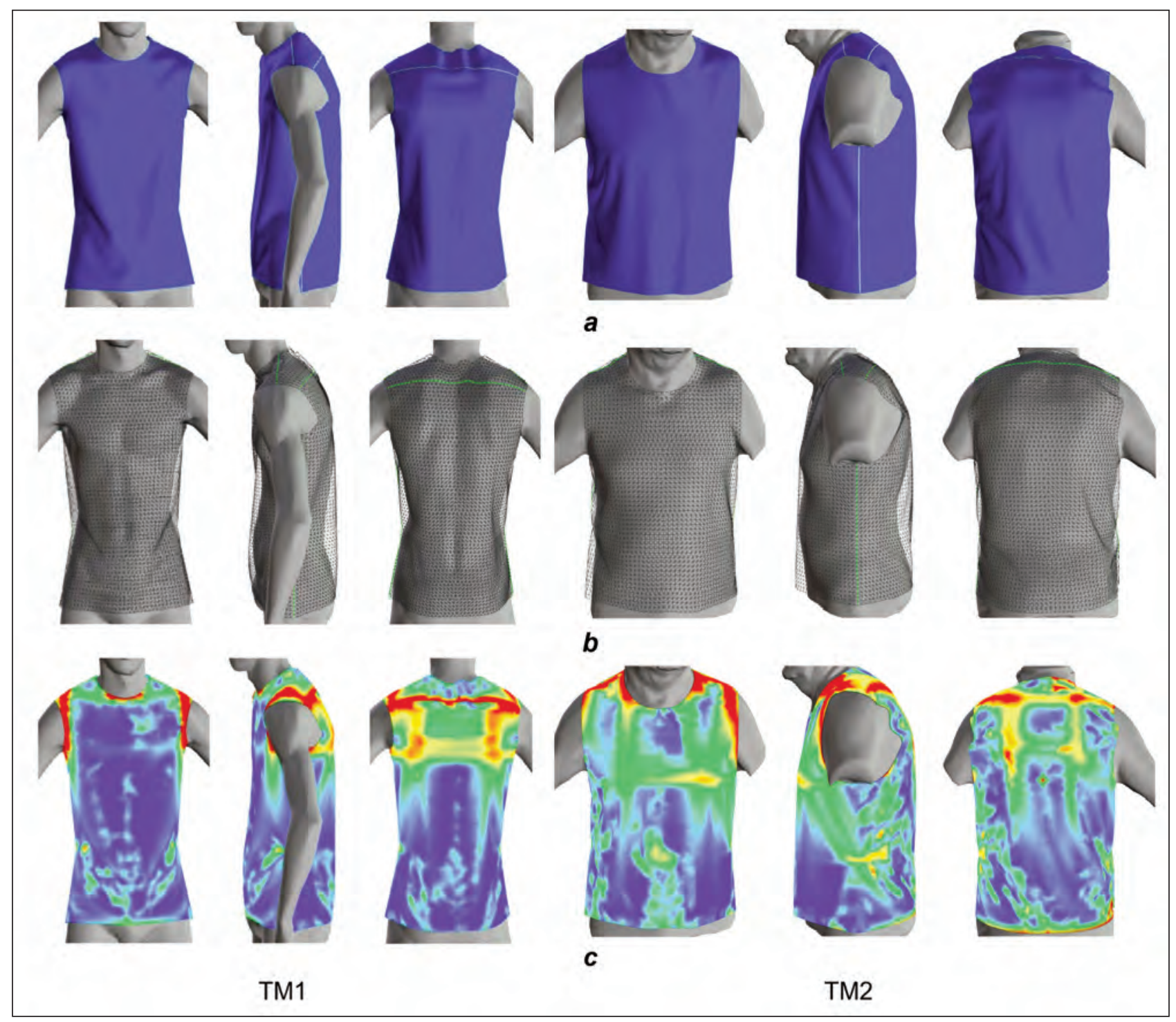

Fig. 7. Virtual fitting of the sleeveless basic shirts pattern designs to TM1 and TM2

Table 5

\begin{tabular}{|c|c|c|c|c|}
\hline \multicolumn{5}{|c|}{ CASP EVALUATION OF THE BACK } \\
\hline SPINE & TF1 & TF2 & TM1 & TM2 \\
\hline C & 6.25 & 6.54 & 6.87 & 8.13 \\
\hline A & 1.19 & 1.05 & 1.26 & 1.19 \\
\hline S & 56.28 & 19.85 & 39.39 & 21.35 \\
\hline P & 0.99 & 1.08 & 1.00 & 1.34 \\
\hline
\end{tabular}

parameter S (39.39) for TM1 compared to the TM2 $(S=21.35)$ arose from the scanning posture and asymmetrical arms posture.

Based on this part of the research it can be seen that both analyses, CASP evaluation and bodies shapes and postures observation give us similar conclusions. This means that CASP methodology and CASP values for surface analysis allows us to predict the degree of curvature of the spine (parameter $\mathrm{C}$ ) and the symmetry of the body (parameter $S$ ), which should be considered in the process of garment pattern designs' adaptions to the body.
Adaption of garments to bodies' deformities and postures

The adaption of garments basic pattern designs according to bodies' deformities and postures were carried out to remove the discomfort of teens and adults when wearing garments (figures 9 and 10). For the female teenager TF1 (strong breast, scoliosis, forward pushed upper part of shoulder blades), we adjusted the basic blouse pattern design only on the front part by increasing breasts girth for $2.0 \mathrm{~cm}$ on dimension of a breasts width and armhole width (figure 9). In this way, a decrease in the tension of the blouse around the breast and at the same time on the back part was achieved. Thus, an average tension of the blouse in relation to the body decreased from $7.42 \mathrm{fg} / \mathrm{cm}$ to $5.5 \mathrm{fg} / \mathrm{cm}$.

For the adult female TF2, showing mild kyphosis and scoliosis, we adjusted the blouse basic pattern design to the body by moving the dart from the armhole to the back middle seam and curved the middle seam from the dart to the neckline (figure 9). When comparing figures 6 and 9 , we can see that the tension 


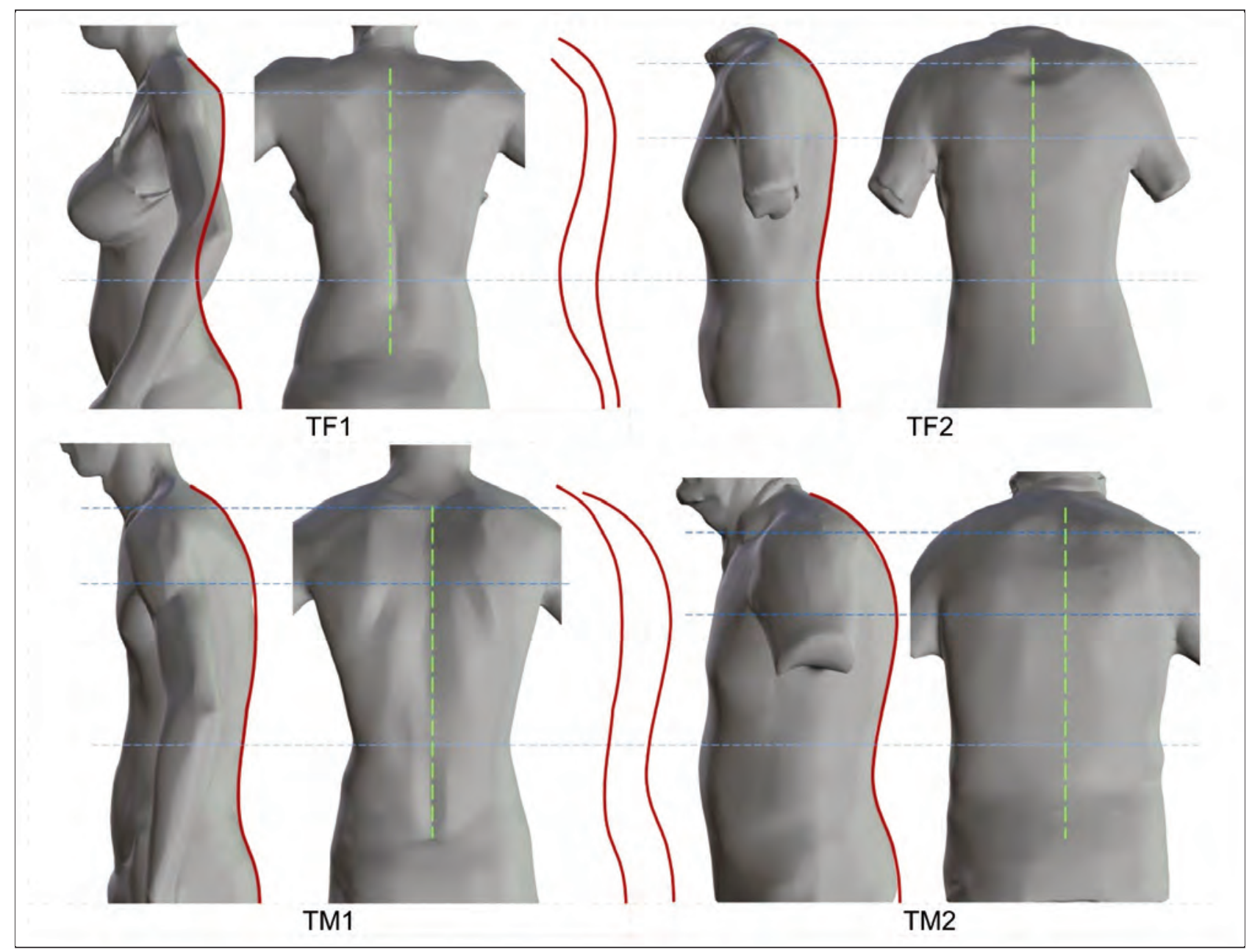

Fig. 8. Scanned persons' spine shapes and postures

in the blouse in the thoracic spine region was released, while the average blouse tension in relation to the body decreased from $11.54 \mathrm{fg} / \mathrm{cm}$ to 11.44 $\mathrm{fg} / \mathrm{cm}$.

3D simulations of the adapted shirts to TM1 and TM2 are presented in figure 10 .

For both male tested persons (TM1, TM2) a decrease of tensions in shirts can be seen after their adaptions when comparing with shirts before adaption and in thoracic spine region, respectively (figures 7 and 10). An average tension was decreased for a teenager TM1 from $5.77 \mathrm{fg} / \mathrm{cm}$ to $4.64 \mathrm{fg} / \mathrm{cm}$ and for an adult from $8.65 \mathrm{fg} / \mathrm{cm}$ to $5.91 \mathrm{fg} / \mathrm{cm}$. During adaption, yoke was omitted from the pattern pieces and the two back pattern pieces were constructed with darts in the middle seam. The dart that was positioned between the yoke and back bottom pattern piece was moved into the back middle seam in the position of the bottom region of the shoulder blades and greatest spine curvature, respectively. In addition, the back middle seam was curved from the dart to the neckline. For the tested person TM1 an armhole was also deepened for $1.5 \mathrm{~cm}$.

In this research an improved garments' fitting to the bodies and higher wearing comfort, respectively, was obtained on the basis of the adaptation of the clothing to the perceived deformities of the spine. The survey showed that despite the construction of garments according to the actual dimensions of the tested persons and rules of the construction system, the clothing items did not fit well, which could cause wearing discomfort. Therefore, the constructed garments needed to be further adapted to individuals. With the help of CASP values and virtual prototyping, we found that for individuals suffering from kyphosis, the shoulder blades' darts should be moved from the armhole to the posterior middle seam and lowered to the line of the inferior point of the shoulder blade. Furthermore, the middle seam should be curved from the dart to the neckline.

\section{CONCLUSIONS}

This article is in line with the research carried out worldwide presenting the applications of virtual 3D simulation technology for testing and completion of clothing products for people with spine deformities. The research was conducted in order to ensure the body-garment correspondence for subjects with morphological features, which are different from the typical ones, such as spine deformity, and who are not able to purchase suitable clothing from the retail network. 


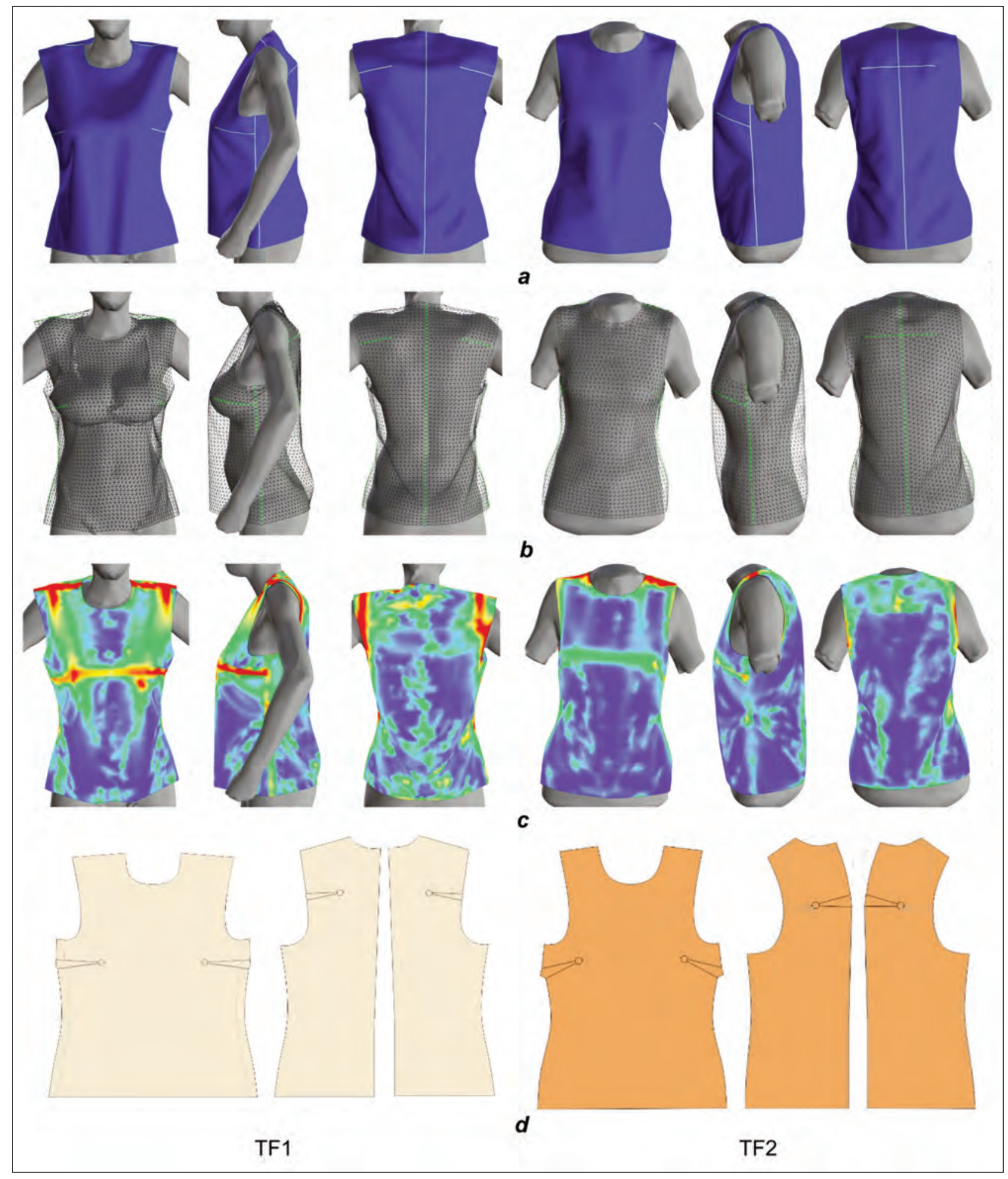

Fig. 9. Virtual fitting of the adapted sleeveless basic blouse pattern designs to TF1 and TF2

The research presents the use of advanced virtual tools and CASP methodology, which may be a useful tool in the procedure of adaption of the garments' pattern designs for people with spine deformity, especially kyphosis. The research regarding the usefulness of the CASP methodology for nonstandard body figures' garment pattern design showed that CASP methodology is adequate for predicting the appropriate garment pattern design for persons with a curved spine, especially kyphosis.
Based on the previous results, this research was focused on scanning the people, both adults and teenagers with spinal deformities, especially kyphosis and construction of the garment pattern designs for them. The results confirmed that the CASP methodology is adequate for defining the appropriate garment pattern design for persons with a curved spine. Namely, the CASP values enable us to assess the degree of kyphosis (parameter C - curvature) or scoliosis (parameter $S$ - symmetry) to be able to 


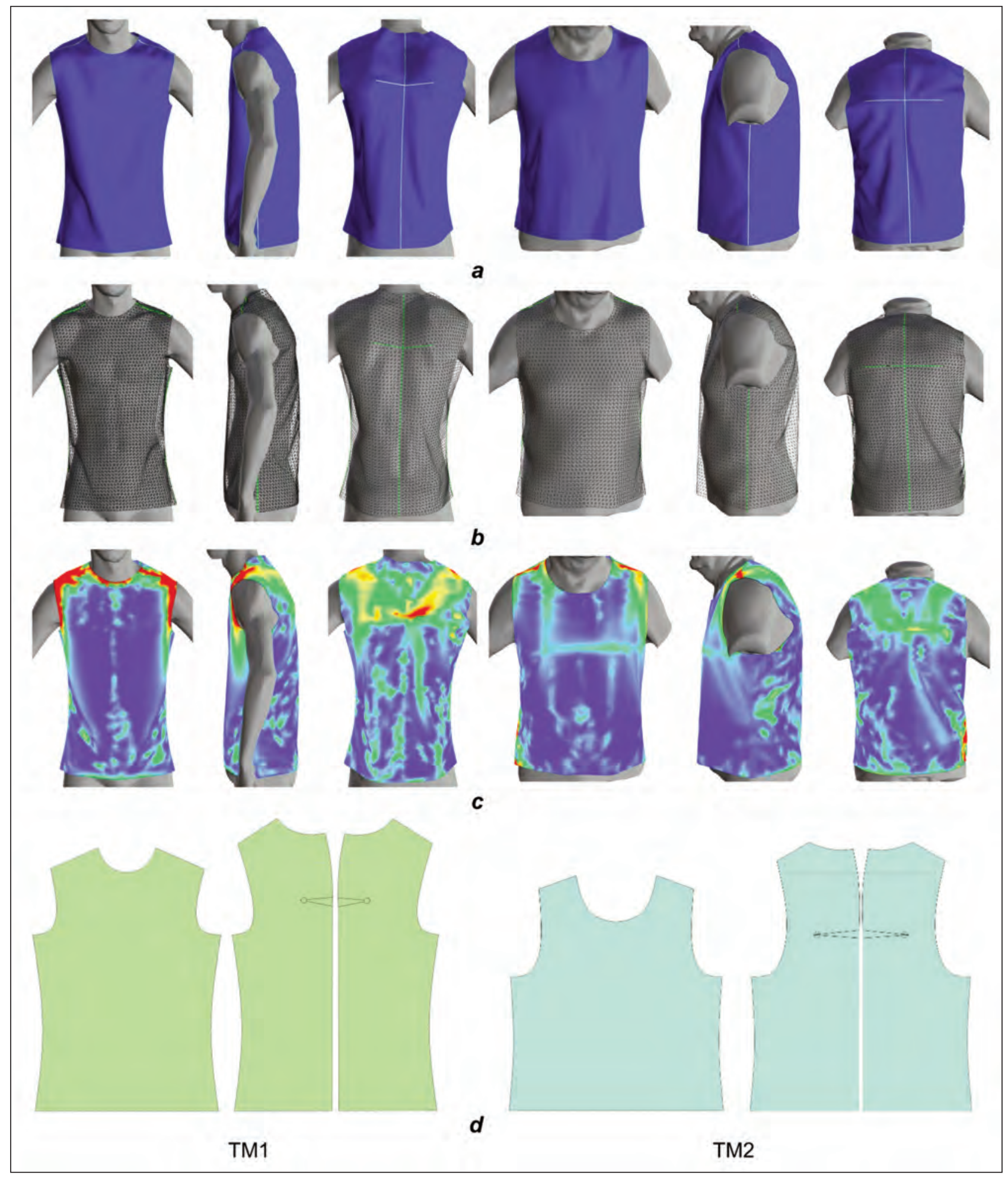

Fig. 10. Virtual fitting of the adapted sleeveless basic shirts pattern designs to TM1 and TM2

properly respond to the reconstruction of the garment pattern design.

The working methodology presented in this article can be used in the completion of the patterns for different degrees of kyphosis and clothing products by the professionals working in the clothing industry, so that people with atypical bodies can benefit from clothing products that will respond to a higher level of requirements imposed by specific shape of the body.

\section{ACKNOWLEDGEMENT}

The authors would like to express their thanks to the Slovenian Research Agency (Research Programme P20123: Clothing Science, Comfort and Textile Materials), which funding enabled the realisation of a part of this study. A part of the research (during the trainee ship) and publication of the paper is funded by the Romanian Ministry of Research and Innovation within Program 1 - Development of the national RD system, Subprogram 1.2 - Institutional Performance - RDI excellence funding projects, Contract no. $6 \mathrm{PFE} / 2018$.

Cooperation of tested persons is appreciated. 


\section{REFERENCES}

[1] Thomas, L., Pediatric spinal deformities, Available from: https://www.news-medical.net/health/Pediatric-SpinalDeformities.aspx, Accessed: 14.05.2019

[2] Scoliosis Research Society, Kyphosis in the adolescent and young adult 2016, Online Education \& Resources, Available from: http://www.srs.org/professionals/online-education-and-resources/conditions-and-treatments/ kyphosis-in-theadolescent-and-young-adult, Accessed: 15.05. 2019

[3] Hong, Y., Bruniaux, P., Zhang, J., Liu, K., Dong, M., Chen, Y., Application of 3D-to-2D garment design for atypical morphology: a design case for physically disabled people with scoliosis, In: Industria Textila, 2018, 69, 1, 59-64, http://doi.org/10.35530/lT.069.01.1377

[4] National Osteoporosis Society, Clothing, body image and osteoporosis, Finding clothes to suit a changing body shape after vertebral compression fractures, 2011, Available from: http://www.setrust.hscni.net/pdf/Clothing.pdf, Accessed: 15.05. 2019

[5] Špelić, I., Petrak, S., Complexity of 3D human body scan data modelling, In: Tekstilec, 2018, 61, 4, 235-244, http://doi.org/10.14502/Tekstilec2018.61.235-244

[6] Jiang, L., Ye, J., Sun, L., Li, J., Transferring and fitting fixed-sized garments onto bodies of various dimensions and postures, In: Computer-Aided Design, 2019, 106, 30-42

[7] Wang, X.F., Song, X.Y., Zhang, X., Ying, B.A., Research on constructing a garment pattern design model for intelligent clothing design, In: Textile Bioengineering and Informatics Symposium Proceedings, 2017, 1, 370-376

[8] Neacșu, N.A., Băltescu, C.A, Bălășescu, S., Boșcor, D., The influence of design and aesthetics elements in choosing clothing, In: Industria Textila, 2017, 68, 5, 375-379, http://doi.org/10.35530/IT.068.05.1427

[9] Bogović, S., Rogina-Car, B., Functional design of supportive men's underwear with a microbial barrier, In: Fibres \& Textiles in Eastern Europe, 2019, 25, 5, 43-49

[10] Dabolina, I., Lapkovska, E., Vilumsone, A., Usage of noncontact human body measurements for development of Army Work Wear Trousers, 17th World Textile Conference AUTEX 2017 - Textiles - Shaping the Future, IOP Conference Series: Materials Science and Engineering, 2017, 254, IOP Publishing

[11] Hong, Y., Zeng, X., Bruniaux, P., Liu, K., Interactive virtual try-on based three-dimensional garment block design for disabled people of scoliosis type, In: Textile Research Journal, 2017, 87, 10, 1261-1274

[12] Nakić, M., Bogović, S., Computational design of functional clothing for disabled people, In: Tekstilec, 2019, 62, 1, 23-33, http://doi.org/10.14502/Tekstilec2019.62.23-33

[13] Stjepanovič, Z., Cupar, A., Jevšnik, S., Kocjan-Stjepanovič, T., Rudolf, A., Construction of adapted garments for people with scoliosis using virtual prototyping and CASP method, In: Industria Textila, 2016, 67, 2, 141-148

[14] Rudolf, A., Cupar, A., Stjepanovič, Z., Designing the functional garments for people with physical disabilities or kyphosis by using computer simulation techniques, In: Industria Textila, 2019, 70, 2, 182-191, http://doi.org/ 10.35530/IT.070.02.1592

[15] Cupar, A., Stjepanović, Z., Jevšnik, S., Erveš, R., Rudolf, A., CASP methodology for virtual prototyping of garments for people with postural disorders and spinal deformities. V: BETTANY-SALTIKOV, Josette (ur.), SCHREIBER, Sanja (ur.). Innovations in spinal deformities and postural disorders. Rijeka: InTech, 2017, 69-89

[16] Niculescu, C., Săliştean, A., Olaru, S., Anthropometric parametres of children in Romania, result of the anthropometric survey carried out in 2010-2011, In: Industria Textila, 2012, 63, 4, 176-182

[17] HP 3D STRUCTURED LIGHT SCANNER PRO S3, Available from: https://www8.hp.com/us/en/campaign/ 3Dscanner/overview.html, Accessed 21.08.2019

[18] Rudolf, A., Cupar, A., Kozar, T., Stjepanović, Z., Study regarding the virtual prototyping of garments for paraplegics, In: Fibers and Polymers, 2015, 16, 5, 1177-1192, http://doi.org/10.1007/s12221-015-1177-4

[19] ISO 8559-1:2017. Size designation of clothes - Part 1: Anthropometric definitions for body measurement.

[20] System M. Müller \& Sohn, Schnittkonstruktionenfür Kleider und Blusen, Deutsche Bekleidungs-Akademie München, München, Rundschau Verlag, 1992, 41

[21] Rundschau, H., Die fachzeitschriffürinternationaleherrenmode und schnitt-technik, Hemden der Saison 2012, Hemd Grundschnittschmales Hemd, 7-8, 11-15

[22] Cupar, A., Pogačar, V., Stjepanović, Z., Methodology for surfaces analysis and classification, In: Universal journal of mechanical engineering, 2014, 2, 2, 64-70

[23] CIELAB color model 2015, Available from: http://dba.med.sc.edu/price/irf/Adobe tg/models/cielab.html, Accessed 21.08.2019

[24] Ünal, N., Utkun, E., Impacts of female body shapes on patternmaking, In: Industria Textila, 2018, 69, 6, 519-523, http://doi.org/10.35530/IT.069.06.1222

Authors:

ANDREJ CUPAR ${ }^{1}$, ZORAN STJEPANOVIČ², SABINA OLARU ${ }^{3}$, GEORGETA POPESCU ${ }^{3}$, ADRIAN SĂLIȘTEAN $^{3}$, ANDREJA RUDOLF $^{2}$

${ }^{1}$ University of Maribor, Faculty of Mechanical Engineering, Institute of Structures and Design, Smetanova 17, 2000, Maribor - Slovenia

2University of Maribor, Faculty of Mechanical Engineering, Institute of Engineering Materials and Design, Smetanova 17, 2000, Maribor - Slovenia

${ }^{3}$ National R\&D Institute for Textiles and Leather, Bucharest Lucrețiu Pătrășcanu 16, sector 3, 030508, Bucharest - Romania

e-mail: andrej.cupar@um.si; andreja.rudolf@um.si; office@incdtp.ro

Corresponding author:

ANDREJA RUDOLF

e-mail: andreja.rudolf@um.si 


\title{
A new lean Six Sigma hybrid method based on the combination of PDCA and the DMAIC to improve process performance: Application to clothing SME
}

\author{
DOI: 10.35530/IT.070.05.1595
}

\section{ABSTRACT - REZUMAT}

\section{A new Lean Six Sigma hybrid method based on the combination of PDCA and the DMAIC to improve} process performance: Application to clothing SME

\begin{abstract}
This paper proposes a new Lean Six Sigma (LSS) methodology to improve process for clothing small- and medium-sized enterprise SME. The methodology is based on combination of two approaches which are the PDCA (Plan, Do, Check, and Act) and the DMAIC (Define, Measure, Analyze, Improve, and Control). The combination technique consists in applying the PDCA to continuously improve and control every DMAIC steps. The DMAIC approach has included Lean Six Sigma tools and techniques, as well as the success factors obtained from a survey, to improve its efficiency. The proposed approach is applied to improve the performances indicators such as Z sigma, Cp, cycle time, and lead time for the case of clothing SME in Tunisia. As an example, the Z-sigma has increased from the sigma level was improved from 1.45 to 3.85. The process capability $\mathrm{Cp}$ from 0.5 to 1.3 and the lead time was decreased from 39.47 days to 30.23 days. Finally, the study is concluded by sorting out the effects of the type of produced articles and the presence or not of the quality certification on the application of the proposed approach. The effectives from using PDCADMAIC technique are better when it's applied with certified company, than non-certified one.
\end{abstract}

Keywords: Lean Six Sigma, DMAIC, PDCA, framework, clothing SMEs

\section{O nouă metodă hibrid Lean Six Sigma bazată pe combinația PDCA și DMAIC pentru îmbunătățirea} performanței proceselor: aplicabilitate în IMM-urile producătoare de îmbrăcăminte

Acest studiu propune o nouă metodologie Lean Six Sigma (LSS) pentru îmbunătățirea proceselor de realizare a articolelor de îmbrăcăminte în companiile mici și mijlocii. Metodologia se bazează pe combinarea a două abordări și anume PDCA (Plan, Do, Check, Act) și DMAIC (Define, Measure, Analyze, Improve, Control). Tehnica de combinare constă în aplicarea PDCA pentru îmbunătățirea și controlul continuu ale fiecărei etape a DMAIC. Abordarea DMAIC a inclus instrumentele și tehnicile Lean Six Sigma, precum și factorii de succes, pentru îmbunătățirea eficienței acestuia. Abordarea propusă este aplicată pentru a îmbunătăți indicatorii de performanță, cum ar fi Z sigma, Cp, timpul ciclului și timpul de pregătire pentru IMM-urile producătoare de îmbrăcăminte din Tunisia. Ca exemplu, Z-sigma a crescut de la nivelul sigma, fiind îmbunătățit de la 1,45 la 3,85. Capacitatea procesului, Cp, a crescut de la 0,5 la 1,3 și timpul de pregătire a fost redus de la 39,47 zile la 30,23 zile. În cele din urmă, studiul a fost încheiat prin analiza influenţei tipului de articole produse și certificarea calităţii asupra aplicării metodei. Efectele utilizării tehnicii PDCA-DMAIC sunt mai bune atunci când se aplică la o companie certificată, decât în cazul unei companii necertificate.

Cuvinte-cheie: Lean Six Sigma, DMAIC, PDCA, cadru, IMM-uri producătoare de îmbrăcăminte

\section{INTRODUCTION}

The Lean Six Sigma method is one famous classical approach and it's considered among the most effective business improvement methodology [1]. It is simply a combination of the Lean and Six Sigma. Lean and Six Sigma are complementary methodology [2], and provide a powerful approach when combined. Lean helps to maximize value by improving quality and reducing the source of process shift, whereas Six Sigma helps to reduce source of process variation. Six Sigma reports major root causes to a problem [3]. It has changed over time from a metric to a business strategy [4-5], or to a management strategy [6-7], combined into the culture of the enterprise. This method is widely used in manufacturing firms in the world and is applied in different industrial fields, that include manufacturing [8-12], services [13-14], commercial [15], health care [16] and logistics [17]. The Six Sigma has two continuous models: Design for Six Sigma (DFSS) or Define, Measure, Analyze, Improve Control, (DMAIC). The second model is suitable for the implementation of an existing process. According to [18], if you cannot define your process, you cannot measure, improve and sustain the quality. While DMAIC is used when a product or process is already in existence but performing inadequately, a popular framework for Six Sigma implementation uses DMAIC methodology. Khaled Mili and Tarek Sadraoui use Six Sigma to solve the Straddle carrier routing Problem [19]. Few studies have been reported about the application of Lean Six Sigma in smalland medium-sized enterprises (SMEs) because of several problems [12]. A number of these have focused on barriers and the critical success factors 
in the implementation of Lean, Six Sigma, or LSS approaches [10, 21]. Other studies have focused on roadmaps for implementing LSS in Textile SME. Korthi et al. were integrated model of Lean Six Sigma and ISO 9001:2008 standard based QMS, L6QMS2008 model in a textile mill and thereby achieving annual savings of 2 million INR [22]. In addition the literature on LSS and its application in small- and medium-sized SME textile and apparel industries businesses is limited [23]. Some authors [24] identify the appropriate Lean principles for implementation in textile industry. A case study is carried out in a linen Fabrics industry by [25] using the DMAIC methodology to reduce the shade variations. Lean Six Sigma application still not known and it's limited for large Tunisian SMEs. Tarek Sadraoui et al., propose a new practice of Six Sigma for reduction of the number of conformities and minimization of the number of customers' Complaints for KITAMEUBLE industry in Tunisia [26]. The use of the complex tools remains difficult for small- and medium-sized enterprises (SME) because it requires an adapted model to successfully implement the approach and currently faces tremendous challenges and disruptive changes, triggered by new and capital intensive technologies [27]. In order to ensure the improvement of projects, LSS utilizes the Define, Measure, Analyze, Improve, Control (DMAIC) approach [28-29], integrating lean tools into a standard Six Sigma DMAIC cycle. According to [30] and [31] the systematic implementation of this approach makes the LSS application very effective. For this reasons, we can find many LSS implementation frameworks which are based on DMAIC, to drive the improvements [32-33]. Vijaya Sunder M. presents the importance for instilling process improvement culture, especially in LSS deployment and demonstrates how LSS project management can bring significant change in a retail bank [14]. Authors such as [31-32, 9], have proposed specific Six Sigma and LSS implementation frameworks, based on DMAIC, to drive the improvement of specific processes. In other studies, DMAIC approach has been applied, with specific tools in every stage [34-35, 9]. Tools such as Value Steam Mapping, Total Productive Maintenance (TPM), DoE, SPC, 5S and QFD are still a key to LSS implementation success [36].

Some authors [37] proposes a new LSS Framework based on the integration of the DMAIC cycle at each point in the Lean thinking cycle. One issue of this method is that the predominance given to the Six Sigma DMAIC cycle within the existing LSS framework can make Lean viewed and utilized as a tool kit of techniques, and removes the opportunity to use Lean as a strategic thinking approach within the LSS framework. This can drive quality-based improvement projects rather than Lean-based projects or projects that create a dual impact of both quality and efficiency improvement. Everton et al. identify and analyze the difference and the complementariness in the production areas for three models, Lean Six Sigma and Lean Six Sigma [38]. S. Karthi and S.R.
Devadasan integrate Lean Six Sigma, and ISO 9001: 2008 standard based Quality Management System, as a single framework benefiting contemporary organization [39]. A few numbers of academic studies in manufacturing have been done on it despite the existence of LSS for a while [36].

A few Six Sigma and LSS studies of SMEs have been done over time. The result of the pilot survey presented in the work of Antony 2007 in UK manufacturing SMEs, which is primarily based on descriptive statistics, shows that many of the SMEs are not aware of Six Sigma. For its successful implementation in SME, management involvement and participation, and linking Six Sigma to customers and to business strategy are the most critical factors for the successful deployment of Six Sigma in SMEs [39]. The result of the survey in our study in Tunisian Clothing SME shows that: The involvement and commitment of top management Performance measurement and communication are the most critical factors for the successful deployment of Six Sigma in these SMEs [40]. In the same context, Taner (2012) surveyed textile SMEs in Turkey and found that lack of knowledge about Six Sigma was the key reason why most SMEs were not implementing Six Sigma [41]. That's way, the hybrid approach which is based in the use of more than one technique have been introduced to overcome the limitation of classical approaches. As stated before, there are two different hybrid approaches which are given in the literature. Combining or integration approach between PDCA, as most effective tool, and the DMAIC as one model of the Six Sigma, starts to be a common technique to improve the systems performances in the last few years. In the following, these approaches are reviewed and analyze. In general, we distinguish two main techniques. In the first one, the DMAIC is applied for each PDCA steps. We called it DMAICapplied-to-PDCA. In the second technique, there is a similar relationship between DMAIC and PDCA, in other terms, every step in the DMAIC find an equivalent in PDCA steps; we called it DMAIC-similar-toPDCA.

The principal of the first technique consists in applying the DMAIC technique to the PDCA cycle. Every single steps of the PDCA is subjected to be controlled by all over the DMAIC cycle in order to improve the standard implementation, as well as the process [42]. The second technique is based on the similarity in the principals of PDCA and the DMAIC. In other terms, there is equivalence between every singles steps or more from the DMAIC and the PDCA steps. For example the equivalent of Plan is Define; the equivalent of Do is Measure... In this approach, the PDCA is the main player that influences the performance of the DMAIC and not the opposite as in the first one. The advantage of this approach is to relate Six Sigma initiative to PDCA cycle in order to ensure the comprehensive micro and macro within an organization [43]. 
Although that these hybrid methods bring some advanced comparing to the classical ones, they still present some limitations and drawbacks which are:

- Even that the first approach to be effective according to his others, its principal seems to be not logic and reasonable. This is because the PDCA by its nature as a helpful procedure could not be subjected to the DMAIC approach, but the opposite. In fact it's the PDCA which should be used to improve the DMAIC. Every approach, which is being introduced into an organization, can be checked against the PDCA cycle, which proves our idea.

- The second limitation is that the given study presents lack of implementation in real word applications, which reduce the effectiveness of the presented methods.

- In the second approach, we think that improving one or more steps of the DMAIC using only one step of the PDCA is not sufficient to improve all the process. This because every DMAIC step can be seen as a complete process from the side of the PDCA.

The main contributions of this work are:

- To develop a novel methodology based on the integration of two approaches PDCA and DMAIC, in order to improve the system efficiency and ensure the continuous improvements.

- To review and analyze the existing approaches used in process improvements systems.

- To apply the developed approach on one certified Tunisian clothing SME producing technical articles and compare the obtained results with other noncertified one producing Denim articles.

\section{MATERIAL AND METHOD}

This article presents a study on deployment of LSS framework in Tunisian clothing SME. The developed framework is based on the integration between DMAIC approach and PDCA cycle. The framework incorporates the tools, techniques and the critical success factors (CSFs) of LSS application, which are determined by a survey in a sample of well studies clothing SMEs, to be applied for each DMAIC steps. We think that a new methodology has to be introduced in order to solve the discussed issues. This methodology is basically the opposite of the DMAICapplied-to-PDCA because it's more effective that every step to be subjected to all the PDAC cycle. The principal of the proposed approach is basically the opposite of the DMAIC-applied-to- PDCA, so that, we called it PDCA-applied-to-DMAIC. The principal is described by figure 1. The established framework PDCA is applied to each DMAIC steps to improve continuously the process, focusing on continuous learning and knowledge creation. The PDCA (PlanDo-Check-Act), cycle is the basic procedure of TQM. It is more than quality tool but also is a fundamental approach of continuous improvement. In fact, it was considered as a well-established framework for process improvement where it focuses on continuous learning and knowledge creation. We choice the
PDCA cycle because it adds the rigor of project lifecycle (PLC) to the implementation and close-out of Lean Six Sigma projects. Every approach, which is being introduced into an organization, can be checked against the PDCA cycle, as follows: The 'Plan' phase allows verifying that applied approaches are well integrated and focused on the all needs. The 'Do' phase aims to check the systematic implementation of these approaches and the existence of appropriate measurement tools. In the 'Check' and 'Act' phases, we can check that these approaches are measured and improved. While Lean six sigma projects in companies can be adhered to a system that ensures continuous improvement such as PDCA. We believe framing Six Sigma projects within a PDCA cycle provides a more comprehensive view of Six Sigma implementation in clothing SMEs. In this section, the developed methodology, to come out with a LSS model in order to improve the quality and the production in clothing SME, is presented. This model is applied for the case study of tow clothing SMEs to: (1) Achieve a higher quality; (2) Increase process speed; (3) Reduce waste and (4) Increase Customer satisfaction. Every step is detailed below.

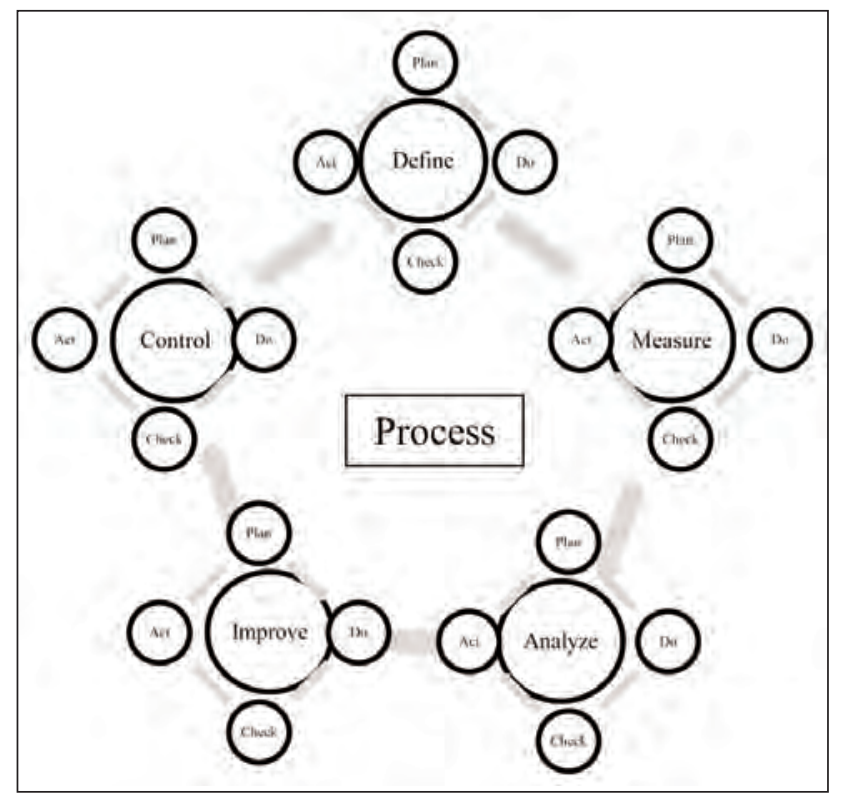

Fig. 1. PDCA-applied-to-DMAIC

\section{RESULTS}

\section{Modeling a LSS methodology}

The developed model uses the technique of integration between DMAIC approach and PDCA cycle. In our work, we have chosen to apply the PDCA cycle to every single step of DMAIC (figure 2). This can improve every sub-system performance and therefore, it can guarantee the success of the complete process. This procedure is applied to all the DMAIC steps, but in our paper we limit to give explanation of Define step. The details of DMAIC structure are given in figure. As it can be seen, the tools and techniques have been integrated into the corresponding DMAIC step. We mentioned that the modeling of the DMAIC 


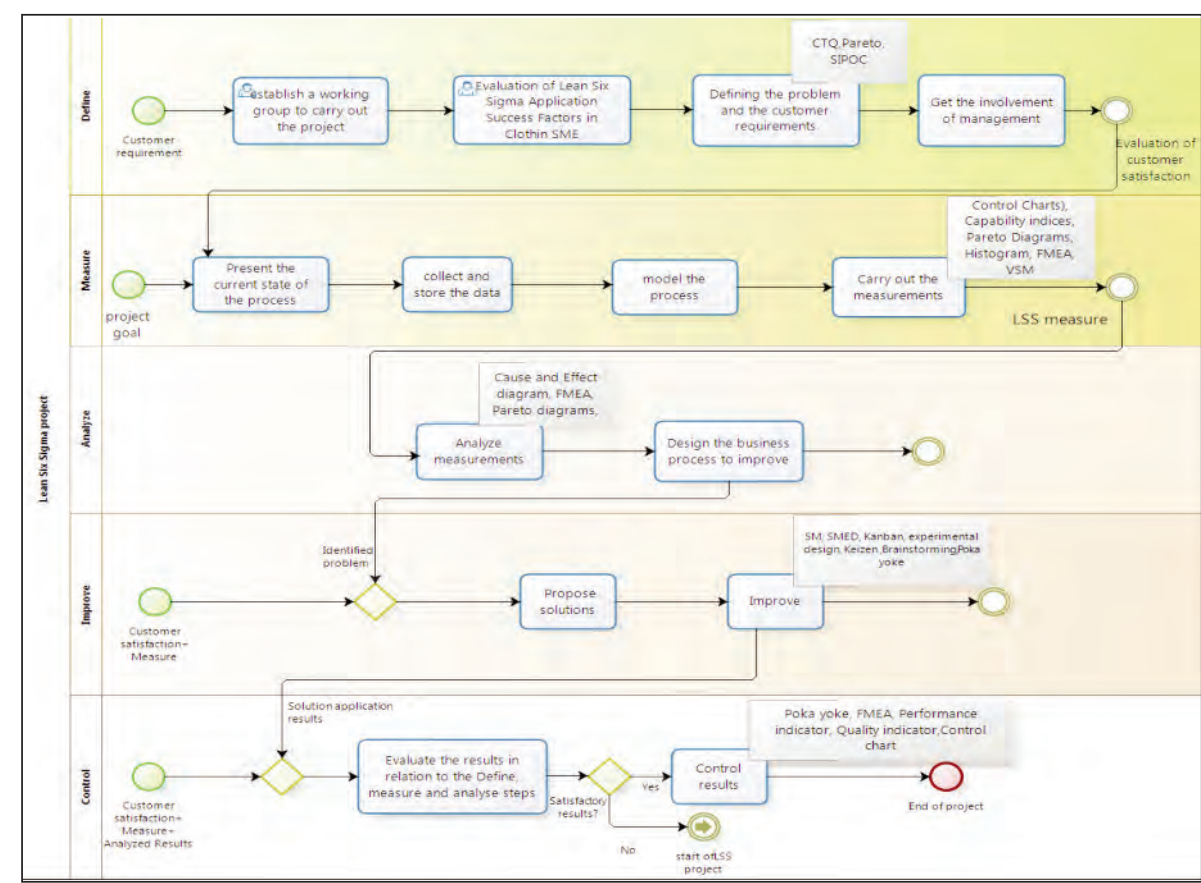

Fig. 2. Modeling a LSS methodology DMAIC steps the importance of and the need for the Lean Six Sigma project and its deliverables. A project schedule SIPOC (Supplier Input Process Output Customer) diagram for the entire loading operation was created in order to provide a clear picture on the suppliers, customers, needed input materials and the sequence of processes involved in manufacturing the product (figure 3).

\section{$>$ The Measure phase:}

In this step, data on measurable indicators of production processes are collected. The objective is to determine the sigma of the process which in turn can give us an idea about the process capability index and approach was carried out using the BPMN standard, because it can give an easy and clear picture of relationship between DMAIC steps.

\section{PDCA Cycle for Define}

Plan:

The objective of the Plan step is to reach the customer satisfaction which represents the main output of Define-step, and to develop its necessary sub-stages.

Do:

The Do step consists in the real implementation of the Plan step.

Check:

In the check step, the customer satisfactions are continuously evaluated, also the success key factors are controlled to prevent any problems and to guarantee the success of Define step.

Act:

In case there is a lack in the required outputs, or any undesirable results, the Act step is applied to fix the problem and to improve the process performances.

\section{Case study}

The study was conducted in a small clothing company specialized in the manufacturing of automotive articles located in Tunisia. The firm is certified with ISO 9001. It interested in improving its sigma level and the customer value.

\section{$>$ The Define phase:}

The initial step in the Define phase consists in forming the team. The project team should be composed by with employees, who are responsible for performing the ship loading process. As management commitment is the most important key of LSS implementation success. A meeting was prepared by the top management in order to explain the employees about

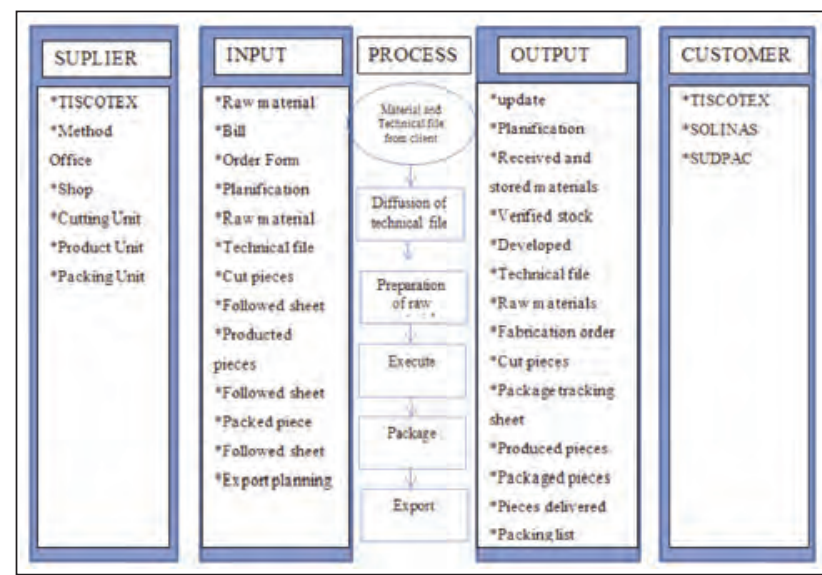

Fig. 3. High level SIPOC diagram of the case study

hence its performances and Identify the types of waste generated by the studied processes.

\section{Process capability Measure}

The analysis of capability is performed to find out actual state of the process]. Once the data are calculated, two sub-processes capability studies are conducted: production and cutting.

The variation for both processes (production and cutting) capability is shown in figures 4 and 5 .

From these figures, we conclude that both processes are incapable, because the $\mathrm{Cp}$ is lower than 1.33. The $Z$ of the complete process is equal to 1.45 .

\section{Process modeling and Simulation}

We propose to show the interest of using the simulation not only to validate the modeling of the process but also to define and position the data acquired to calculate the performance indicators and to test the proposed improvements before implementing them on the actual process of a clothing SME. This modeling and simulation will be done with BPMN standard 


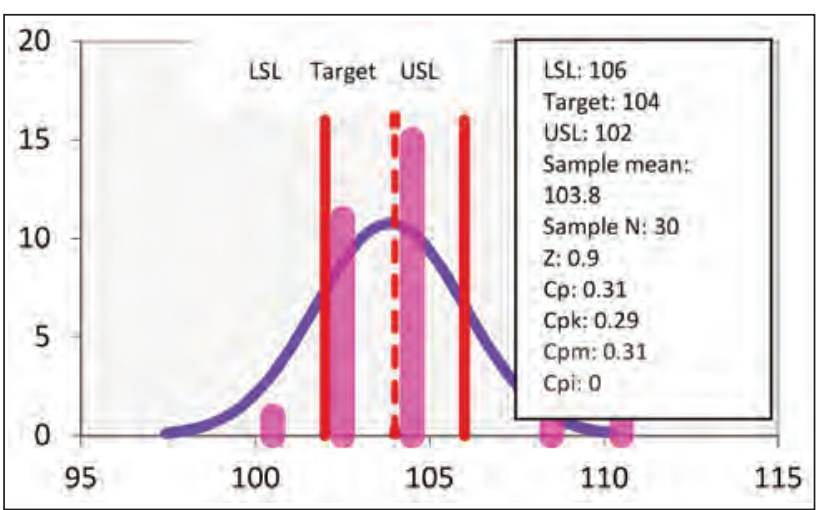

Fig. 4. Process capability of cut sub-process report before improvements implementation

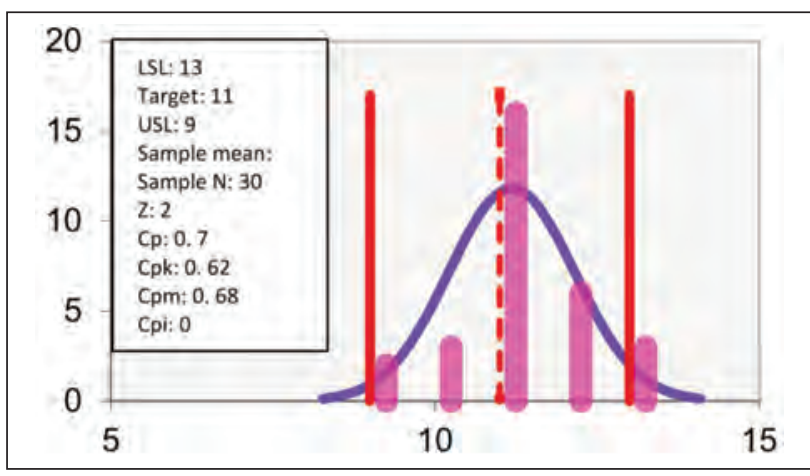

Fig. 5. Process capability of production sub-process report before improvements implementation

using the tool BiZagi (figure 6). Table 1 summarizes the evaluation of performance indicator.

Table 1

EVALUATION OF PERFORMANCE INDICATOR

\begin{tabular}{|l|l|}
\hline \multicolumn{1}{|c|}{ Indicator } & \multicolumn{1}{c|}{ Values } \\
\hline Cycle time & $9 \mathrm{~h} 15 \mathrm{~min}$ \\
\hline Total average waiting time & 8 hour 35 minute 23 s \\
\hline Value added time & 24 min $25 \mathrm{~s}$ \\
\hline Resource utilization & $\begin{array}{l}\text { - Post prepare piece: } 98,9 \% \\
\text { - Post Mount piece: } 41,2 \%\end{array}$ \\
\hline
\end{tabular}

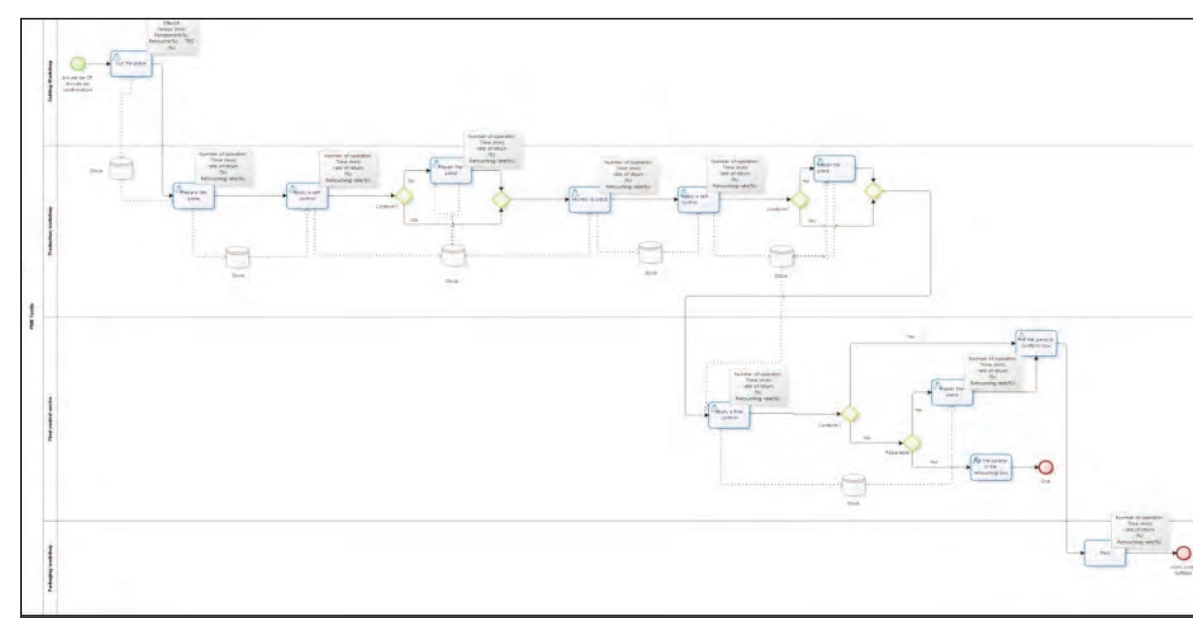

Fig. 6. BPMN diagram model of the sub-processes
Analysis phase:

The analysis phase examines the collected data in order to generate a prioritized list of source of variation in order to identify the root cause and to analyze the problems of process inefficiencies, using the result of the step "Measure". The used tools in our work are the following:

- Identification of failure modes and their causes Based on the available data, the main rejection defects of the product were identified. Seven failure modes that led to the rejection were identified. Table 2 shows the main rejection and their category for the net.

Table 2

\begin{tabular}{|c|c|}
\hline \multicolumn{2}{|c|}{ MAIN REJECTION AND ITS CATEGORY } \\
\hline Defect & Category of defect \\
\hline $\begin{array}{l}\text { The net is assembled in the } \\
\text { wrong position }\end{array}$ & Security defect \\
\hline Incorrect net height & Security defect \\
\hline Incorrect total length & Security defect \\
\hline Low resistance of keder & Security defect \\
\hline Discontinuous stitching & Customer satisfaction \\
\hline Incorrect position of loop & Customer satisfaction \\
\hline Incorrect keder length & Security defect \\
\hline
\end{tabular}

All these defects have effects on user safety, customer satisfaction, or on the installation of the article in the truck. In fact during an accident, the net does not perform its main function of preventing the user from moving forward.

- Root cause analysis

The cause and effect diagram (as shown in figure 7) was drawn to find out the causes of "security defect". Sub-causes were categorized into five general cause categories namely Material, Personnel, Milieu, Methods and Machines.

Cause and effect diagram shows that the most important causes that affect the defect are essentially due to: operator error, bad machine setting, lack of material control at reception, or lack of worker training. We analyzed all other types of defect using the cause-effect diagram

\section{> Improve Phase}

We have concretized the planed actions, respect the deadlines. Since the training and education is among the key factors of success of LSS application, training to the employees involved in implementation of the improvement activities are provided in order to assure the successful implementation. Tools and techniques 5S, Kaizen, Poke yoke and 


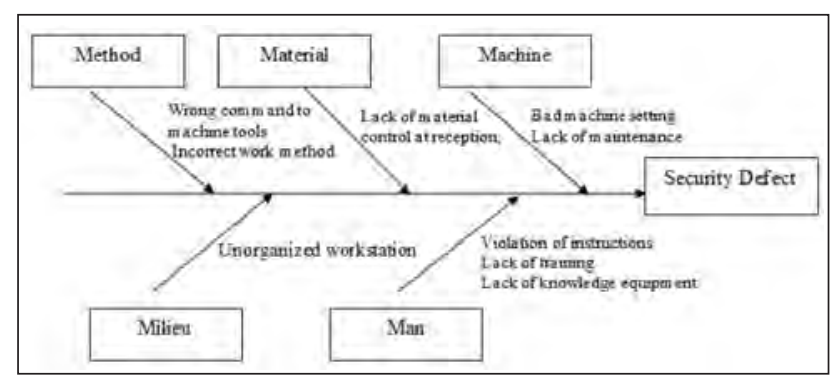

Fig. 7. Cause and effect diagram

other process improvement techniques are applied for planning the improvement activities related to quality and productivity. To validate the obtained results of the improve phase, a confirmatory test was implemented by measuring again process capability and performance indicators.

Table 3

PROPOSED SOLUTION FOR REJECTION DEFECT

\begin{tabular}{|l|l|}
\hline \multicolumn{1}{|c|}{ Defect } & \multicolumn{1}{c|}{ Proposed solution } \\
\hline $\begin{array}{l}\text { The net is assembled } \\
\text { in the wrong position }\end{array}$ & $\begin{array}{l}\text { Construction of a table by } \\
\text { serving Poke yoke }\end{array}$ \\
\hline $\begin{array}{l}\text { Low resistance of } \\
\text { keder }\end{array}$ & $\begin{array}{l}\text { Request to do tests in the } \\
\text { laboratory }\end{array}$ \\
\hline $\begin{array}{l}\text { Discontinuous } \\
\text { stitching }\end{array}$ & $\begin{array}{l}\text { Fixing number of pieces per } \\
\text { bobbin }\end{array}$ \\
\hline $\begin{array}{l}\text { Incorrect position of } \\
\text { loop }\end{array}$ & $\begin{array}{l}\text { Placing two markings on the } \\
\text { table for the loop position }\end{array}$ \\
\hline Incorrect keder length & $\begin{array}{l}\text { Cut the keder in the workshop } \\
\text { Use the lime cutter fixed on the } \\
\text { table } \\
\text { Place a mark on the cutting table }\end{array}$ \\
\hline
\end{tabular}

Table 4

CORRECTIVE ACTIONS FOR EXISTING MUDA TYPE

\begin{tabular}{|l|l|}
\hline \multicolumn{1}{|c|}{ MUDA type } & \multicolumn{1}{c|}{ Corrective actions } \\
\hline $\begin{array}{l}\text { Excessive } \\
\text { displacement }\end{array}$ & $\begin{array}{l}\text { Minimize the displacement by creating } \\
\text { a storage area in the chain }\end{array}$ \\
\hline $\begin{array}{l}\text { Excessive } \\
\text { storage }\end{array}$ & $\begin{array}{l}\text { Minimize the quantity manufactured } \\
\text { per lot }\end{array}$ \\
\hline $\begin{array}{l}\text { Unnecessary } \\
\text { operations }\end{array}$ & $\begin{array}{l}\text { Eliminate intermediate control, Study } \\
\text { and develop key workplace }\end{array}$ \\
\hline
\end{tabular}

Table 3 and 4 show the improvement activities proposed by the team members. Appropriate solutions were provided for each defect and were implemented. $5 S$

Before the application of the improvement project using the 5S method, the key factors of success in order to successfully implement the $5 S$ are fixed.

To reduce the non-value added time for employees, the team starts working on the pillars constituting the $5 S$ method.

\section{Implementation of process Kaizen}

Kaizen Continuous improvement (kaizen) is one of the principle concepts that support the Toyota
Production System (TPS). The kaizen activities were proposed to improvise activity that does not create any value. The kaizen activities were planned such that the overall performance gets improved.

\section{Creation of a facility layout}

We have organized separate standalone workflows after applying operator training to different operations performing in the same cell. The process flow allowed us to identify a waste in terms of transport. In order to optimize the movement between the workstations and the storage areas of raw materials and accessory, we implemented storage area in the workflow. Figures 8 and 9 show the existing layout and the modified layout.

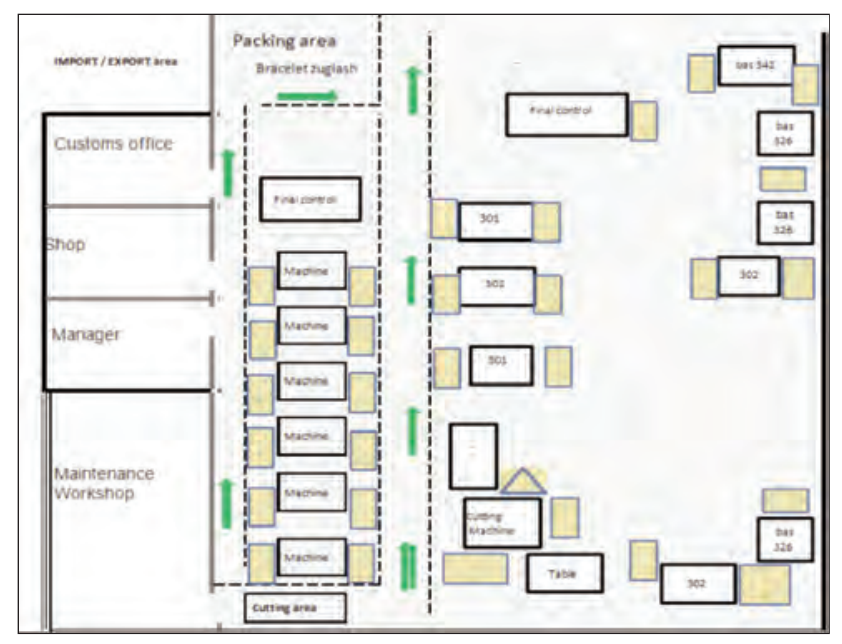

Fig. 8. Existing layout

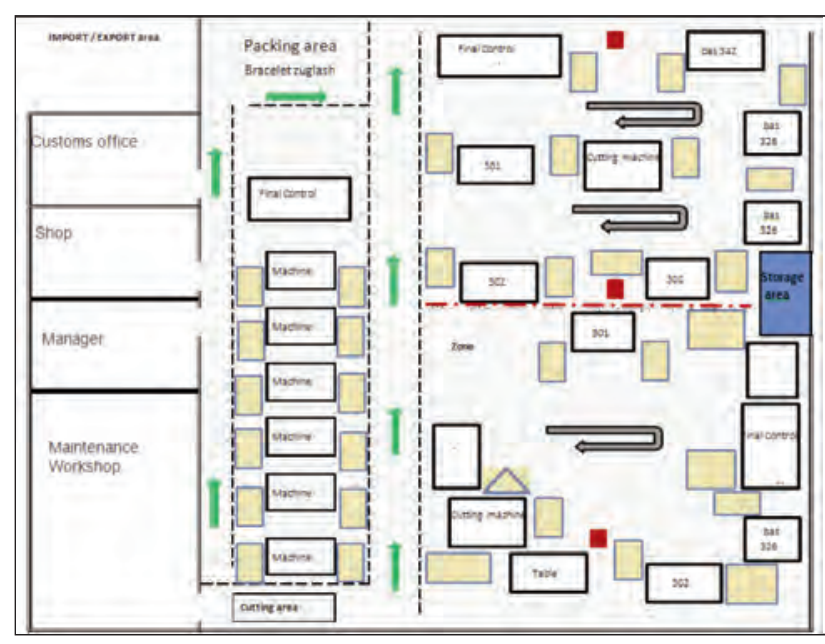

Fig. 9. Modified layout

\section{Validation of best solutions}

In order to validate the obtained results of the improve phase, a confirmatory tests were conducted to validate the modifications. Results showed that after implementing the improvement actions, variation has been decreased consistently and the process is properly centered. Sample of 30 components were taken and were measured in two sub-processes to find its process capability. The process is shifted towards the center mean and it is capable of 


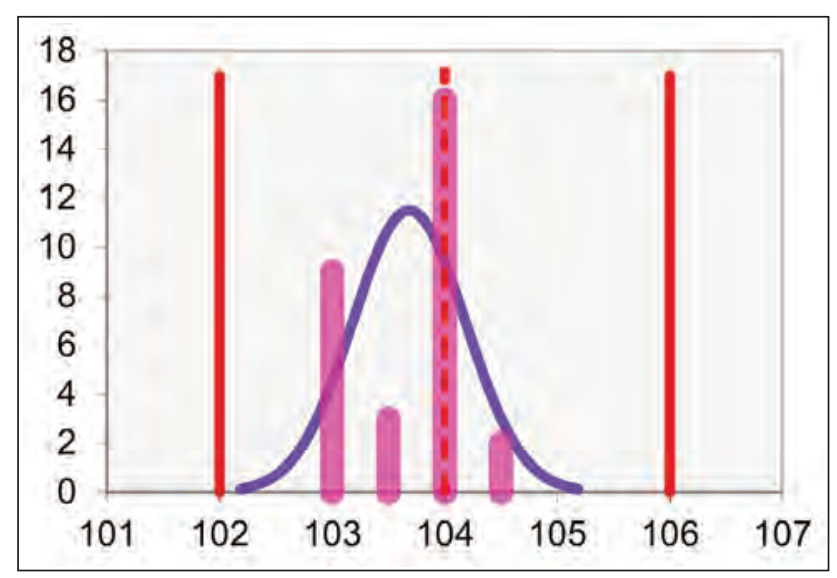

Fig. 10. Process capability of sub-process production report after implementation

Table 5

PROCESS PERFORMANCE INDICATORS BEFORE IMPROVEMENTS

\begin{tabular}{|l|c|c|c|c|c|}
\hline $\begin{array}{c}\text { Sub-pro- } \\
\text { cess }\end{array}$ & $\mathbf{C p}$ & $\mathbf{Z}$ & $\begin{array}{c}\text { Process } \\
\text { capability }\end{array}$ & BPMO & $\begin{array}{c}\mathbf{Z} \\
\text { process }\end{array}$ \\
\cline { 1 - 4 } Cut & 1.3 & 3.89 & Capable & & \\
\cline { 1 - 4 } Production & 1.36 & 4.07 & Capable & & 3.89 \\
\hline
\end{tabular}

producing the components with the specification limits. The obtained process capability for two sub-processes after implementing the improvement actions is shown in figure 10 and figure 11 . Table 5 presents the significant improvements after implementation of Lean Six Sigma methodology of processes.

\section{Control phase}

The applied improvements have been fully integrated into the training regime and the process documentation, the information related to company performance was sharing with its employees. A regular audit of parameters setting was carried out. Visual management, Total Productive Maintenance and Process FMEA are to be implemented after completion of the project to provide a visual aid for controlling the key input and output variables pertaining, and to ensure the team could not revert back to old habits. The control charts are a powerful tool for achieving process control and stability. For this project, the implementation of control charts was important to check that the product meet the desired specifications. Figure 12 shows the control charts for the sub-process cut and sub-process production respectively. We can show the process in general, is in control and stable.

\section{$>$ Evaluation of the PDCA-applied-on-DMAIC}

The DMAIC approach which is applied in certified company is again applied with a non-certified one different in specialization to investigate its effects on the performance of both companies. Table 6 shows the results after improvements of two companies: The key metrics used for comparing the results after

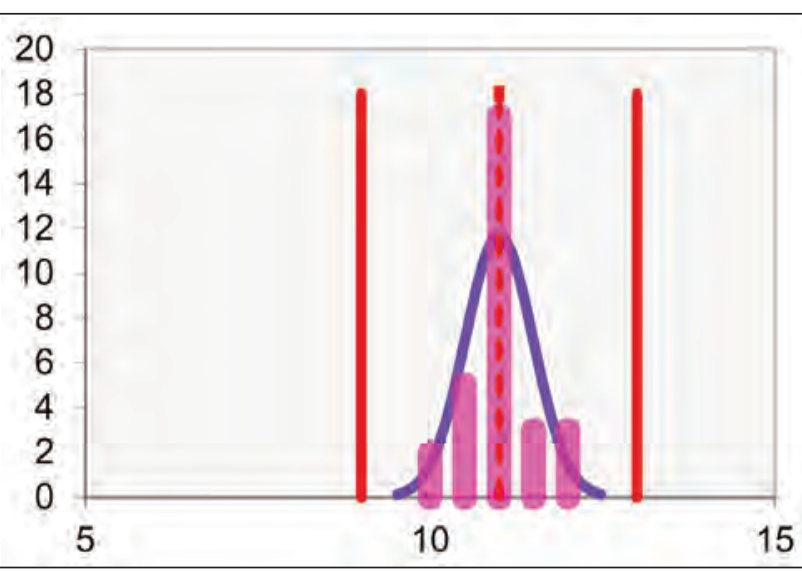

Fig. 11. Process capability of sub-process cut report after implementation

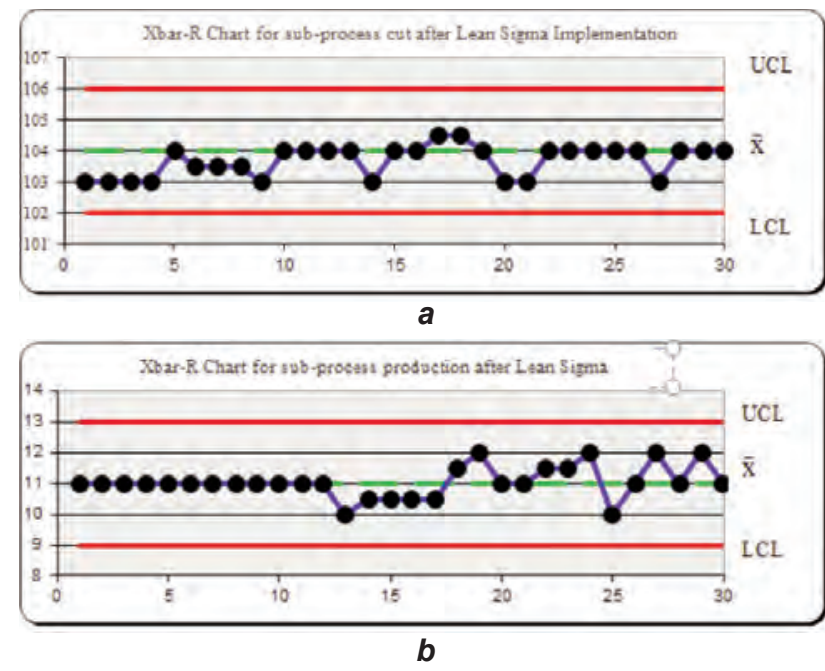

Fig. 12. Control chart of process for (a) sub-process cut and (b) sub-process production

implementing the Lean Six Sigma framework included Z-Sigma, Process Capability Cp, Defects per million opportunities (DPMO), Cycle time and Lead time. The main conclusion that can be summarized from the obtained results and indicators shown in table are:

- The effectives from using PDCA-DMAIC technique are better when it's applied with certified company, than non-certified one. This is because they already applied standards tools of the ISO 9001 witch can help to better use of Lean Six

- The type of produced article has also a considerable effect on the success or not of Lean Six Sigma application, for example security articles recommend some obligation to reduce at a minimum the safety defects.

- The increase of $Z$ in SME specialized in denim articles are not of ease and achievable task because the probability of defects is high.

\section{DISCUSSION}

On completion of this project, we have first concluded that the existing approaches have several limitations and issues, these limitations can be due to a 
RESULTS BEFORE AND AFTER IMPROVEMENTS OF TWO COMPANIES

\begin{tabular}{|l|c|c|c|c|}
\hline \multirow{2}{*}{ Key metrics used } & \multicolumn{2}{|c|}{ Technical articles (Certified ISO 9001) } & \multicolumn{2}{c|}{ Denim articles (Not Certified ISO 9001) } \\
\cline { 2 - 5 } & Before improvements & After improvements & Before improvements & After improvements \\
\hline Z-Sigma & 1.45 & 3.85 & 0.7 & 1.2 \\
\hline Cp & 0.5 & 1.3 & 0.2 & 0.7 \\
\hline DPMO & 540000 & 10700 & 780000 & 308000 \\
\hline Cycle time & 19.92 min & 14.54 min & 12.79 min & 10.1 \\
\hline Lead Time & 39.47 day & 30.23 day & day & 13 day \\
\hline
\end{tabular}

lack in a good comprehension on how to apply the hybrid techniques such as the case of DMAICapplied-to-PDCA. In addition to that, these approaches don't find a real application in our real word which limits its use and the reliability of the given results. On the other side, the new proposed approach has better fundamental basis as it uses the PDCA, which is one of the most effective tool, to continuously improve and control the DMAIC process. In contrast to the existing approaches which have a lack of real application, we have applied this proposed approach to clothing certified SME. The approach also integrate Lean Six Sigma tools and techniques like Kaizen, Pokayoke, Pareto..., and the key factors for LSS success. These tools were determined from survey achieved in a Tunisian clothing sample SMEs and used in every DMAIC step.

The results prove that the proposed approach can be used as an effective and efficient tool to improve process performance. As an example the sigma level was improved from 1.45 to 3.85 . Improvements were observed from I lean metrics such as cycle time and lead time.

Furthermore, the proposed was applied in other noncertified SME producing denim article to investigate the effect of whether the company is certified and the effect of the produced articles on the rate of success of LSS implementation. It was shown that the effectives from using PDCA-DMAIC technique are better when it's applied with certified company, than noncertified one and the type of produced article has also a considerable effect on the success or not of Lean Six Sigma application, for example security articles recommend some obligation to reduce at a minimum the safety defects.

\section{CONCLUSIONS, LIMITATIONS AND FUTURE RESEARCH DIRECTIONS}

This study aims to propose a new Lean Six Sigma (LSS) methodology to improve the process perfor- mances indicators such as $Z$ sigma, $\mathrm{Cp}$, cycle time, and lead time for the case of clothing SME in Tunisia. The methodology is based on combination of two approaches which are the PDCA (Plan, Do, Check, and Act) and the DMAIC (Define, Measure, Analyze, Improve, and Control). Finally, the study is concluded by sorting out the effects of the type of produced articles and the presence or not of the quality certification on the application of the proposed approach.

In our case study, as with our recent work [40], Management commitment and involvement was the most important Critical success factors and the Acceptance of Lean Six Sigma Culture was the most important indicator for implementation of LSS in clothing SME. Although initially, the employees of the studied case believed that the implementation of LSS could affect their performance change their working practices, and eventually endanger their job opportunities. Other major issue was only basic lean tools and techniques had previously been employed (5S, etc.) because of the lack of knowledge about Lean Sigma tools by the employees.

The proposed LSS framework has been test implemented in two Tunisian Textile SMEs, one is certified producing technical article and one non-certified producing denim article, and focused on addressing one specific problem (i.e. defect). In the future, this framework can be used as a base and adapted to drive improvements in other textile SMEs and to hold other operational problems. In addition, more tools and techniques can be added, or removed, from the framework for specific adaptation and improvement.

\section{ACKNOWLEDGEMENTS}

We would like to thank the director of the company in which we applied our work.

\section{REFERENCES}

[1] Laureani, A., Antony, J., Critical success factors for the effective implementation of Lean Sigma: Results from an empirical study and agenda for future research, In: International Journal of Lean Six Sigma, 2012, 3, 4, 274-283

[2] Peteros, R.G., Maleyeff, J., Using Lean Six Sigma to improve investment behavior, In: International Journal of Lean Six Sigma, 2015, 6, 1, 59-72 
[3] Darshak, A., Desai, Antony, J., Patel, M.B., An assessment of the critical success factors for Six Sigma implementation in Indian industries, In: International Journal of Productivity and Performance Management, 2012, $61,4,426-444$

[4] Basant, C., Dixit, G., Ashish, A., Framework to improve performance through implementing Lean Six Sigma strategies to oil exporting countries during recession or depression, In: International Journal of Productivity and Performance Management, 2016, 65, 3, 422-432

[5] Ang, Boon, Sin, Suhaiza, Z., Mohammad, I., Ramayah, T., Structural Equation Modelling on Knowledge Creation in Six Sigma DMAIC Project and Its Impact on Organizational Performance, In: Int. J. Production Economics, 2016, 168, 105-117

[6] Vijaya, Sunder, M., Rejects reduction in a retail bank using Lean Six Sigma, In: Production Planning \& Control, 2016, 27, 14, 1-12

[7] Gijo, E.V., Antony, J., Kumar, M., McAdam, R., Hernandez, J., An application of Six Sigma methodology for improving the first pass yield of a grinding process, In: Journal of Manufacturing Technology Management, 2014, 25, 1, 125-135

[8] Ben Ruben, R., Vinodh, S., Asokan, P., Implementation of Lean Six Sigma framework with environmental considerations in an Indian automotive component manufacturing firm: a case study, In: Production Planning \& Control, 2017, 28, 15, 1-19

[9] Krueger, D.C., Parast, M.M., Adam, S., Six Sigma Implementation: A Qualitative Case Study Using Grounded Theory, In: Production, Planning \& Control, 2014, 25, 10, 873-889

[10] Timans, W., Antony, J., Ahaus, K., Van Solingen, R., Implementation of Lean Six Sigma in small-and medium-sized manufacturing enterprises in the Netherlands, In: Journal of the Operational Research Society, 2012, 63, 3, 339-353

[11] Anderson, N.C., Kovach, J.V., Reducing welding defects in turnaround projects: A Lean Six Sigma case study, In: Quality Engineering, 2014, 26, 2, 168-181

[12] Kumar, M., Antony, J., Singh, R.K., Tiwari, M.K., Perry, D., Implementing the Lean Sigma framework in an Indian SME: a case study, In: Production Planning \& Control, 2006, 17, 4, 407-423

[13] Sunder, V., Antony, J., Six-sigma for Improving Top-box Customer Satisfaction Score for a Banking Call Centre, In: Production, Planning \& Control, 2015, 26, 16, 1291-1305

[14] Vijaya, Sunder, M., Rejects reduction in a retail bank using Lean Six Sigma, In: Production Planning \& Control, 2016, 27, 14, 1-12

[15] Garza-Reyes, J.A., Al-Balushi, M., Anthony, J., Kumar, V., A Lean Six Sigma framework for the reduction of ship loading commercial time in the iron ore pelletising industry, In: Production Planning \& Control, 2016, 27, 3, 1092-1111

[16] Hicks, C., McGovern, T., Prior, G., Smith, I., Applying Lean Principles to the Design of Healthcare Facilities, In: International Journal of Production Economics, 2015, 170, 677-686

[17] Sadraoui, T., Fayza, J., Efficacité de la Méthodologie Six Sigma dans la Gestion de la Chaine Logistique, In: International Journal of Econometrics and Financial Management, 2014, 2, 6, 220-235

[18] Sokovic, M., Pavletic, D., Kern Pipan, K., Quality improvement methodologies - PDCA Cycle, RADAR Matrix, DMAIC and DFSS, In: Journal of achievements materials and Manufacturing Engineering, 2010, 43, 1, 476-483

[19] Mili, K., Sadraoui, T., Six Sigma Approach for the Straddle Carrier Routing Problem, In: International Journal of Econometrics and Financial Management, 2014, 2, 1, 34-47, http://doi.org/10.12691/ijefm-2-1-5

[20] Timans, W., Ahaus, K., Antony, J., Six Sigma methods applied in an injection mouldingcompany, In: International Journal of Lean Six Sigma, 2014, 5, 2, 149-167

[21] Manville, G., Greatbanks, R., Krishnasamy, R., Parker, D.W., Critical success factors for Lean Six Sigma programmes: a view from middle management, In: International Journal of Quality \& Reliability Management, 2012, 29, 1, 7-20

[22] Karthi, S., Devadasan, S.R., Selvaraju, K., Sivaram, N.M., Sreenivasa, C.G., Implementation of Lean Six Sigma through ISO 9001:2008 based QMS: a case study in a textile mill, In: Journal of The Textile Institute, 2013, 104, 10, 1089-1100

[23] Dede, Adikorley, R., Rothenberg, L., Lean Six Sigma applications in the textile industry: a case study, In: International Journal of Lean Six Sigma, 2016, 8, 2, 210-224

[24] George, D., Mallery, P., SPSS for Windows step by step: A simple guide and reference, 11.0 update (fourth Ed.), 2003, Boston: Allyn \& Bacon

[25] Das, P., Roy, S., Antony, J., An application of Six Sigma methodology to reduce lot-to-lot shade variation of linen fabrics, In: Journal of Industrial Textiles, 2007, 36, 227-251

[26] Sadraoui, T., Ghorbel, A., Design process improvement through DMAIC Sigma approach: A wood consumption case study, In: International Journal of Productivity and Quality Management, 2011, 7, 2, 229-262

[27] Tudor, L., Change in Textile and Clothing Industry, In: Industria Textila, 2018, 69, 1, 37-42, http://doi.org/ 10.35530/IT.069.01.1449

[28] Cudney, E.A., Furterer, S., Dietrich, D., Lean Systems: Applications and Case Studies in Manufacturing, Service, and Healthcare, Boca Raton, 2013, FL: CRC Press 
[29] Voehl, F., et al., The Lean Six Sigma Black Belt Handbook: Tools and Methods for Process Acceleration, CRC Press, Boca Raton, In: American Journal of Operations Research, 2013, 5, 3

[30] Garza-Reyes, J. A., Flint, A., Kumar, V., Antony, J., Soriano-Meier, H., A DMAIRC Approach to Lead Time Reduction in an Aerospace Engine Assembly Process, In: Journal of Manufacturing Technology Management, 2014, 25, 1, 27-48

[31] Zhang, M., Wang, W., Goh, T.N., He, T., Comprehensive Six Sigma Application: A Case Study, In: Production, Planning \& Control, 2015, 26, 3, 219-234

[32] Vinodh, S., Kumar, S.V., Vimal, K.E.K., Implementing Lean Sigma in an Indian Rotary Switches Manufacturing organization, In: Production Planning \& Control, 2014, 25, 4, 288-302

[33] Thomas, J., Francis, M., Fisher, R., Byard, P., Implementing Lean Six Sigma to overcome the production challenges in an aerospace company, In: Production Planning \& Control, 2016, 27, 7-8, 1-13

[34] Garza-Reyes, J.A., Al-Balushi A., Antony, J, Kumar, V., A Lean Six Sigma framework for the reduction of ship loading commercial time in the iron ore pelletising industry, In: Production Planning \& Control, 2016, 27, 13, 1-20

[35] Sushovan, G., Maiti, J., Data mining driven DMAIC framework for improving foundry quality - a case study, In: Production Planning \& Control, 2014, 25, 6, 478-493

[36] Saja, A.A, Antony, J., Abdul halim Lim, S., A systematic review of Lean Six Sigma for the manufacturing industry, In: Business Process Management Journal, 2015, 21, 3, 665-691

[37] Jones, E.C., Parast M.M., Adams, S.G., A framework for effective Six Sigma implementation, In: Total Quality Management \& Business Excellence, 2010, 21, 4, 415-424

[38] Drohomeretski, E., Gouvea da Costa, S.E., Pinheiro de Lima, E., Da Rosa Garbuio, P.A., Lean, Six Sigma and Lean Six Sigma: an analysis based on operations strategy, In: Production Planning \& Control, 2014, 52, 3, 804-824

[39] Kumar, M., Critical Success Factors and Hurdles to Six Sigma Implementation: The Case of a UK Manufacturing SME, In: International Journal of Six Sigma and Competitive Advantage, 2007, 3, 4, 333-351

[40] Nedra, A., Néjib, S., Yassine, CH., Morched, CH., Critical success factors of Lean Six Sigma implementations within small and medium Tunisian clothing industries, In: International Conference of Applied Research on Textile, CIRAT7, 2016, Hammamet, Tunisia

[41] Taner, M.T., Critical Success Factors for Six Sigma Implementation in Large-scale Turkish Construction Companies, In: International Review of Management and Marketing, 2013, 3, 4, 212-225

[42] Lupan, R., Bacivarof, I.C., Kobi, A., Robledo, C., A relationship between Six Sigma and ISO 9000:2000, In: Quality Engineering, 2005, 17, 4, 719-725

[43] Jones, E.C., Parast, M.M., Adams, S.G., A framework for effective Six Sigma implementation, In: Total Quality Management \& Business Excellence, 2010, 21, 4, 415-424

\section{Authors:}

ABBES NEDRA, SEJRI NÉJIB, CHAABOUNI YASSINE, CHEIKHROUHOU MORCHED

Textile Engineering Laboratory (LGTEX), Higher Institute of Technical Studies of ksarhellal (ISET),

Monastir University, Tunisia

Corresponding author:

ABBES NEDRA

e-mail: Nedraabbes2@gmail.com 


\section{Fashion designer selection with the method of GRA-based intuitionistic fuzzy multi-criteria decision making}

DOI: $10.35530 / I T .070 .05 .1421$

\section{ABSTRACT - REZUMAT}

Fashion designer selection with the method of GRA-based intuitionistic fuzzy multi-criteria decision making

Personnel selection is a decision making problem based on the determination of the most suitable individual in line with the determined criteria, as known. Particularly in the labor-intensive sectors, such as apparel, the choice of the right personnel is a crucial problem and plays a key role in continuing the life cycle of companies successfully. In this study, the fashion designer selection process is examined for the design departments which are one of the most important organs for the apparel companies. For this purpose, the most suitable designer was chosen for an apparel company operating in Izmir province. In order to fulfill the aim, criteria weights which play an active role in designer selection are obtained through AHP method, and intuitive fuzzy logic sets are utilized to enable the evaluations of the candidates by the experts according to the criteria. In the light of these data, the final choice was conducted with the method of grey relational analysis.

Keywords: apparel sector, designer selection, multiple attribute decision making, GRA

\section{Selecția designerilor de modă pe baza metodei de luare a deciziilor multicriteriale fuzzy intuitive pe baza GRA}

Selecția personalului este o problemă de luare a deciziilor bazată pe identificarea celui mai potrivit individ, în conformitate cu criteriile determinate. În special, însectoarele cu program de lucru intensiv, precum confecționarea îmbrăcămintei, alegerea personalului potrivit este o problemă crucială și deține un rol cheie în continuarea cu succes a activității companiilor. În acest studiu, procesul de selecție a designerilor de modă este analizat pentru departamentele de proiectare, care reprezintă unele dintre cele mai importante departamente pentru companiile producătoare de îmbrăcăminte. În acest scop, a fost selecționat cel mai potrivit designer pentru o companie producătoare de îmbrăcăminte, care operează în provincia Izmir. Pentru a îndeplini obiectivul, ponderile criteriilor care joacă un rol activ în selecția designerilor sunt obținute prin metoda AHP, iar seturile cu logică fuzzy sunt utilizate pentru a permite evaluarea candidaților de către experți, în conformitate cu criteriile. Pe baza acestor date, selecția finală a fost realizată cu metoda de analiză și corelație gri.

Cuvinte-cheie: sectorul de îmbrăcăminte, selecția designerilor, luarea deciziilor multicriteriale, GRA

\section{INTRODUCTION}

Personnel selection arises as a decision making problem based on the selection of the most suitable individual for the work and organization among other candidates. The selection of the best and the most qualified employees is one of the crucial decisions in terms of the companies, since the knowledge, skills and abilities of these employees are the factors that directly affect the future of the company. Nowadays, companies face the developments in the technology and science and the growing intensity of the competition owing to the globalization. In this concept, it is observed that methods based on logic and mathematical background are increasingly widespread and put into practice, which is also valid for the personnel selection processes. Such methods allow a systematic reflection of the decision makers' opinions included in the selection problem, whereas enabling a more concrete and transparent selection process to be carried out from the candidate's point of view.

Looking at the literature, it appears that several techniques and different criteria are utilized in order to perform the analysis and the selection process of individuals from different sectors for different positions. The methods such as AHP, ANP, TOPSIS, fuzzy TOPSIS and fuzzy PROMETHEE seem to be frequently used by researchers in the studies based on the personnel selection [1-3]. One of these methods is the Grey Relational Analysis (GRA) and the Intuitionistic Fuzzy Sets (Fuzzy Sets) which are the subject of this study. For the selection of project manager for a technology firm and in another study, the selection process of the appropriate teaching personnel was analyzed with the help of GRA method [4-5]. Also, this method was applied to a technology company in the selection process of a software engineer [6]. In the study carried by Bali et al. [7], the selection process of a technology company was addressed through the Dephi technique and intuitionistic fuzzy sets. As shown in the literature, these methods are commonly used in personnel selection, but have been found to be limited in regard to the area of textiles and apparel. The common features of the aforementioned methods are that they are based 
on the Multiple Criteria Decision Analysis (MCDA) methods which are applied in the cases of several criteria affecting the result and they also allow the objective assessments. For this reason, it is considered that MCDA techniques can also be utilized in this field, textiles and apparel, as it is thought that the personnel selection processes in this area are performed under several criteria.

The apparel sector has a complicated structure with different dynamics. The growing competition, the increase in the expectations of customers, the constant increase in the number of the seasons and the variety of designs in order to adapt to the changing fashion trends, can be stated as the couple of reasons for this situation. Due to this structure of the sector, the personnel to be recruited must be selected among the individuals who have the qualifications to keep up with the companies' culture and have the ability of following the trends of the sector closely and adapting them. There are a number of studies available in the literature considering the personnel selection in the field of textiles and apparel. In another study [8], the techniques of survey, Delphi and BEI (Behavioral Event Interviewing) and proximity analysis were used in combination for the selection of the best personnel for the sales department in the textile sector. In another study, a survey was carried out with twenty-five different apparel enterprises located throughout Turkey and the researcher tried to reflect the personnel selection strategies of these companies [9]. Sener [10] ranked individuals for selecting blue-collar personnel for the production quality control in textile sector according to their suitability in the context of AHP method. In another study carried out in 2015, the selection of blue-collar personnel for sewing and quality control tasks to be employed in an apparel company was carried out through the AHP method [11].

In this study, the fashion designer selection process for the design department of an apparel company was investigated order to select the suitable personnel. One of the most important reasons for this selection is that the important position of the design department for having a direct affect in the customer profile and also the profitability of the company. The limited studies concerning the fashion designer selection in the apparel industry is noticed and therefore the study is thought to contribute to the literature in this respect. Within the scope of the study, Grey Relational Analysis is utilized which is one of the multi-criteria decision making methods including the evaluation process based on several criteria and verbal judgments and the most suitable designer for the company is determined among the other designer candidates.

\section{MATERIAL AND METHOD}

The study was carried out in consultation with the company of Spazio, operating in İzmir province. In 1980 , the company started its professional commercial activities by opening a ready to wear oriented boutique rather than bespoke tailoring which consists of the start-up stage of the company. In the 2000s, after the second generation-managers were included in the administration, the company has continued to have its presence under the brand name of Spazio. The company has been designing and producing in the area of women's daily wear, sportswear and night dresses. The company has eleven stores in total, including Aydın, Denizli and Izmit, provided that the majority of these stores are located in Izmir. As of 2016, the total number of personnel employed by the company is 60 , the annual production capacity is 100,000 pieces and the annual average turnover is 15 Million TL.

The company has been looking for a qualified designer who can contribute to the Spazio brand and also appeal to the customers' taste with the right designs. The method proposed in this study is based on the evaluations of the eligible candidates. Accordingly, the hierarchy consisting of the criteria in accordance with the criteria determined by the company experts that can be used in the selection of the designer is summarized in (figure 1).

Previous collection preparation experiences, mastery of the computer programs such as Photoshop and Adobe Illustrative which are related to design, having organization and management skills in order to be able to follow up the production of the designed products, following the developments in the area, possessing a research oriented character and having a vision and goals compatible with the company culture are the features expected from the designer candidates to be hired for the brand. The interviews were conducted and the decision problem was discussed within the framework of the following criteria with the Spazio chief designer who is also one of the second generation managers, as she is responsible for recruiting the designers.

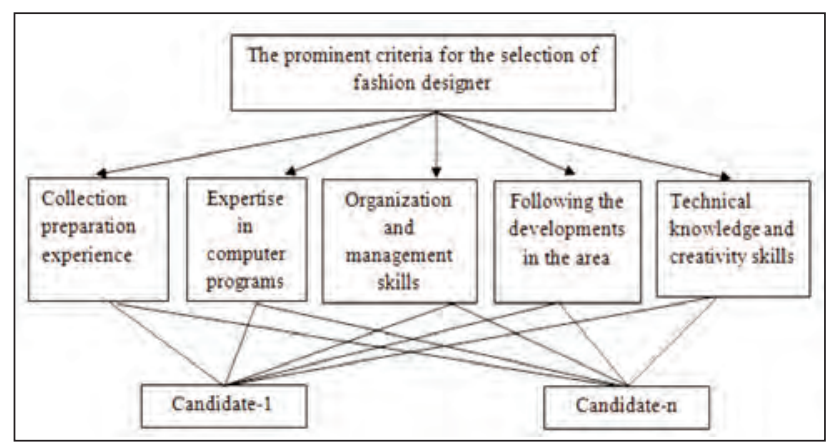

Fig. 1. Hierarchical structure consisting of the criteria considered in the selection of fashion designer for the company

In this study, the weights of the criteria which play an active role in choosing the designer to be recruited were determined by the AHP method, whereas the evaluations of the candidates were conducted by utilizing the intuitionistic fuzzy logic sets, according to the afore mentioned criteria. Finally, the final choice for this data was done through grey relational analysis method. 
The Fuzzy Set theory proposed by Zadeh attracted many researchers and it has been used in various fields. According to the fuzzy set theory, membership values of a set of elements can have values between 0 and 1 , and the sum of the membership and nonmembership degrees of an element is equal to 1 . However, the concept of fuzzy sets is extended to intuitionistic fuzzy sets by Atanassov [12]. In this concept, intuitionistic fuzzy set is characterized by a membership function, non-membership function and as well as a third function called the hesitation degree which enable to depict the data analyzed more comprehensively than fuzzy set which is only characterized by a membership function. Moreover, the grey relational analysis (GIA) method proposed by Deng [13] has been widely used in various multiple decision making problems. It has been proven to be useful in decision making under the circumstances including multiple factors [7]. The characteristics and the preliminaries of these theories are summarized as follows [14-15].

According to the concept of intuitionistic fuzzy sets, the set of the alternatives is expressed as $X=\left\{x_{1}, x_{2}\right.$, $\left.\ldots, x_{m}\right\}$, the discrete cluster showing the possible alternative set is defined as $i=1,2, \ldots, m$. The set of the criteria is expressed as $C=\left\{c_{1}, c_{2}, \ldots, c_{n}\right\}$, where $n$ defines a finite set indicating the number of relevant criteria. The vector of the criteria weights is expressed as $\omega=\left(\omega_{1}, \omega_{2}, \ldots, \omega_{n}\right)$, where $\omega_{j} \geq 0, j=1,2, \ldots, n$ and $\sum_{j=1}^{n} \omega_{j}=1$.

The functions of $\mu_{A}(x)$ and $v_{A}(x)$ denote, respectively, the degree of membership and the degree of nonmembership of the element $x \in X, A \subseteq X .(x)$ is called the degree of indeterminacy membership of the element $x \in X$ to the set $A$. It is assumed that this may arise from the information loss or personal errors. If the relation of these three forms is expressed in the following way, it becomes possible to mention the presence of an intuitionistic fuzzy set (1).

$$
\pi_{A}(x)=1-\mu_{A}(x)-v_{A}(x)
$$

According to the grey relational analysis concept, the original reference set is expressed as $x_{0}(j)$ and $x_{i}(j)$ is the value of $i$ th alternative with respect to $j$ th criterion, where $i=1,2, \ldots, m ; j=1,2, \ldots, n$ assuming that there are $m$ alternatives and $n$ criteria. The grey relational coefficient is computed via the following equation (2), here the distance between $x_{i}$ and $x_{0}$ is calculated through the following equation (3), which is also defined by other researchers as it is shown in (4).

$$
\begin{gathered}
\xi_{i j}=\frac{\delta_{\min }+\rho \delta_{\max }}{\delta_{i j}+\rho \delta_{\max }}, i \in M, j \subseteq N \\
\delta_{i j}=d\left(r_{i j}, r_{0 i}\right) \\
d\left(\alpha_{1}, \alpha_{2}\right)=\frac{1}{2}\left(\left|\mu_{\alpha 1}-\mu_{\alpha 2}\right|+\left|v_{\alpha 1}-v_{\alpha 2}\right|+\right. \\
\left.+\left|\pi_{\alpha 1}-\pi_{\alpha 2}\right|\right)
\end{gathered}
$$

$\rho$ is called as the distinguishing coefficient and usually taken as 0.5 by the decision makers in the literature as this value offers good stability and also good distinguishing effects. Finally, grey relational grade is determined to enable the comparisons between alternatives, which are calculated through (5). Here, $\omega_{j}$ indicates the weight of the $j$ th criterion.

$$
\gamma_{i}=\sum_{j=1}^{n} \omega_{j} \xi_{0 i}(j), \quad i \in M
$$

The application steps of the combination of these methods are indicated in the following steps.

Step 1: Alternatives, criteria and decision makers need to be defined. Subsequently, on the basis of the criteria, each decision maker needs to evaluate alternatives with the help of linguistic variables. If the problem requires, these evaluations can be repeated in a certain number of periods. The intuitionistic fuzzy set is constructed via the intuitionistic fuzzy values of the corresponding linguistic values. The elements forming this matrix are expressed as $r_{i j}=\left(\mu_{i j}, v_{i j}, \pi_{i j}\right)$.

The linguistic variables and their corresponding intuitionistic fuzzy values used in evaluating the alternatives in this study are summarized in the following table 1 [15-16].

Table 1

LINGUISTIC VARIABLES AND CORRESPONDING
INTUITIONISTIC FUZZY VALUES USED
IN THE EVALUATION OF CANDIDATES

\begin{tabular}{|c|c|}
\hline Linguistic variables & Intuitionistic fuzzy values \\
\hline Extreme high $(\mathrm{EH})$ & $(0.95,0.05,0.00)$ \\
\hline Very high $(\mathrm{VH})$ & $(0.85,0.10,0.05)$ \\
\hline High $(\mathrm{H})$ & $(0.75,0.15,0.10)$ \\
\hline Medium high $(\mathrm{MH})$ & $(0.65,0.25,0.10)$ \\
\hline Medium $(\mathrm{M})$ & $(0.50,0.40,0.10)$ \\
\hline Medium low $(\mathrm{ML})$ & $(0.35,0.55,0.10)$ \\
\hline Low $(\mathrm{L})$ & $(0.25,0.65,0.10)$ \\
\hline Very low $(\mathrm{VL})$ & $(0.15,0.80,0.05)$ \\
\hline Extreme low $(\mathrm{EL})$ & $(0.05,0.95,0.00)$ \\
\hline
\end{tabular}

Step 2: In this step, if it is thought that the importance of decision makers vary in the selection problem, the weight assignments are conducted for each of the decision makers.

Step 3: If the selection problem requires a group decision as stated in Step 2, then the aggregated intuitionistic fuzzy decision matrix is constructed based on the opinions of decision makers.

Step 4: Weights of the criteria need to be determined because of the reason that their importance and contributions to the solution of the problem may vary. In this step of this study, the method of AHP was used to determine the criteria weights. As it is known, the hierarchy of the problem needs to be established primarily within this method. Subsequently, the decision makers evaluate the criteria through the pairwise comparison matrices by means of a scale scoring between 1 and 9 . The general measurement scale of AHP consists of the following importance degrees and their relevant descriptions. 
"1: Equally important, 3: Weakly important, 5: Strongly important, 7: Very strongly important, 9: Extremely important, 2-4-6-8: Intermediate values". The consistency of the pair-wise comparison matrices must be tested in the course of determining whether the data are reliable by computing the consistency ratio (CR). If $\mathrm{CR} \leq 0.10$, it means that the consistence of the pair-wise comparison matrix is acceptable [17-18].

Step 5: The reference sequence needs to be determined in order to be able to make comparisons for the criteria. The reference sequence should be the optimal sequence of the criteria values. In the intuitionistic fuzzy decision matrix, the maximum value of $\alpha^{+}=(1,0,0)$ can be used as the reference value. Accordingly, the reference series $x_{0}$ is expressed as follows (6).

$$
x_{0}=\left(r_{0 j}\right)_{1 \times n}=\left[\alpha^{+} \alpha^{+} \alpha^{+} \ldots \alpha^{+}\right]
$$

Step 6: Grey relational coefficient should be determined. For this purpose (2) is utilized.

Step 7: Grey relational grades should be estimated via (5).

Step 8: In the last step alternatives are ranked according to the decreasing order of their grey relational grades and the greater the value of the grey relational grade, the better the alternative is, meaning that this alternative can be chosen as the most appropriate one.

\section{THE FINDINGS OF THE STUDY}

The afore-mentioned steps were followed in order to realize the designer selection.

Step 1: Accordingly, the recruiting specialist, who is primarily the decision maker, identified six alternative designer candidates. The set of alternatives is defined as $X=\left\{x_{1}, x_{2}, \ldots, x_{6}\right\}$ and the set of criteria is defined as $C=\{$ Collection preparation experience, Expertise in computer programs, Organization and management skills, Following the developments in the area, Technical knowledge and creativity skills\}. The human resource recruitment specialist evaluated the designer candidates through the linguistic variables specified in table 1 . The following tables show the evaluations of candidates with linguistic values and their corresponding fuzzy numbers (table 2 and table 3 ).

Steps 2 and 3: These steps have been skipped because the person who is in charge for the selection decision is the chief designer, rather than a group of people.

Step 4: In this step weights of the criteria used in the selection of the designer were determined with the help of AHP method. The criteria factor weights obtained as a result of pair-wise comparisons are listed in table 4 . The CR value obtained for all the matrices constructed in the study was 0.049 . It is possible to say that the data are valid because this

Table 2

\begin{tabular}{|l|c|c|c|c|c|}
\hline \multicolumn{6}{|c|}{ EVALUATION OF THE CANDIDATES WITH THE HELP OF THE LINGUISTIC VARIABLES } \\
\hline Criteria & $\begin{array}{c}\text { Collection } \\
\text { preparation } \\
\text { experience } \\
\left(C_{1}\right)\end{array}$ & $\begin{array}{c}\text { Expertise in } \\
\text { computer } \\
\text { programs } \\
\left(C_{2}\right)\end{array}$ & $\begin{array}{c}\text { Organization and } \\
\text { management } \\
\text { skills } \\
\left(C_{3}\right)\end{array}$ & $\begin{array}{c}\text { Following the } \\
\text { developments } \\
\text { in the area } \\
\left(C_{4}\right)\end{array}$ & $\begin{array}{c}\text { Technical } \\
\text { knowledge and } \\
\text { creativity skills } \\
\left(C_{5}\right)\end{array}$ \\
\hline Candidates $1\left(X_{1}\right)$ & $\mathrm{L}$ & $\mathrm{M}$ & $\mathrm{M}$ & $\mathrm{M}$ & $\mathrm{MH}$ \\
\hline Candidate $2\left(\mathrm{X}_{2}\right)$ & $\mathrm{L}$ & $\mathrm{MH}$ & $\mathrm{MH}$ & $\mathrm{MH}$ & $\mathrm{M}$ \\
\hline Candidate $3\left(\mathrm{X}_{3}\right)$ & $\mathrm{M}$ & $\mathrm{MH}$ & $\mathrm{M}$ & $\mathrm{M}$ & $\mathrm{MH}$ \\
\hline Candidate $4\left(\mathrm{X}_{4}\right)$ & $\mathrm{MH}$ & $\mathrm{MH}$ & $\mathrm{MH}$ & $\mathrm{MH}$ & $\mathrm{M}$ \\
\hline Candidate $5\left(\mathrm{X}_{5}\right)$ & $\mathrm{M}$ & $\mathrm{L}$ & $\mathrm{M}$ & $\mathrm{M}$ & $\mathrm{MH}$ \\
\hline Candidate $6\left(\mathrm{X}_{6}\right)$ & $\mathrm{M}$ & $\mathrm{MH}$ & $\mathrm{L}$ & $\mathrm{M}$ & $\mathrm{MH}$ \\
\hline
\end{tabular}

\begin{tabular}{|c|c|c|c|c|c|}
\hline \multicolumn{7}{|c|}{ INTUITIONISTIC FUZZY VALUES OF THE CORRESPONDING LINGUISTIC VALUES } \\
\hline Criteria & $\begin{array}{c}\text { Collection } \\
\text { preparation } \\
\text { experience }\end{array}$ & $\begin{array}{c}\text { Expertise in } \\
\text { computer } \\
\text { programs }\end{array}$ & $\begin{array}{c}\text { Organization and } \\
\text { management } \\
\text { skills }\end{array}$ & $\begin{array}{c}\text { Following the } \\
\text { developments } \\
\text { in the area }\end{array}$ & $\begin{array}{c}\text { Technical } \\
\text { knowledge and } \\
\text { creativity skills }\end{array}$ \\
\hline Candidates & $0.25,0.65,0.10$ & $0.50,0.40,0.10$ & $0.50,0.40,0.10$ & $0.50,0.40,0.10$ & $0.65,0.25,0.10$ \\
\hline Candidate 2 & $0.25,0.65,0.10$ & $0.65,0.25,0.10$ & $0.65,0.25,0.10$ & $0.65,0.25,0.10$ & $0.50,0.40,0.10$ \\
\hline Candidate 3 & $0.50,0.40,0.10$ & $0.65,0.25,0.10$ & $0.50,0.40,0.10$ & $0.50,0.40,0.10$ & $0.65,0.25,0.10$ \\
\hline Candidate 4 & $0.65,0.25,0.10$ & $0.65,0.25,0.10$ & $0.65,0.25,0.10$ & $0.65,0.25,0.10$ & $0.50,0.40,0.10$ \\
\hline Candidate 5 & $0.50,0.40,0.10$ & $0.25,0.65,0.10$ & $0.50,0.40,0.10$ & $0.50,0.40,0.10$ & $0.65,0.25,0.10$ \\
\hline Candidate 6 & $0.50,0.40,0.10$ & $0.65,0.25,0.10$ & $0.25,0.65,0.10$ & $0.50,0.40,0.10$ & $0.65,0.25,0.10$ \\
\hline
\end{tabular}


value is compatible with the reliability reference of the method, which is $\mathrm{CR}<0.10$.

Table 4

CRITERIA WEIGHTS OBTAINED THROUGH AHP

\begin{tabular}{|l|c|}
\hline \multicolumn{1}{|c|}{$\begin{array}{c}\text { Criteria used in the designer } \\
\text { selection }\end{array}$} & $\begin{array}{c}\text { Criteria } \\
\text { weights }\end{array}$ \\
\hline Technical knowledge and creativity skills & $\omega_{1}=0.276$ \\
\hline Collection preparation experience & $\omega_{2}=0.220$ \\
\hline Organization and management skills & $\omega_{3}=0.220$ \\
\hline Following the developments in the area & $\omega_{4}=0.212$ \\
\hline Expertise in computer programs & $\omega_{5}=0.072$ \\
\hline
\end{tabular}

Step 5: Since all candidates are ideally expected to have the maximum value for each criterion, the maximum value of $\alpha^{+}=(1,0,0)$ is accepted as the reference value in the intuitionistic fuzzy decision matrix. Therefore, the reference series of the problem can be indicated as: $x_{0}=\left(r_{0 j}\right)_{1 \times 5}=\left(\left(\mu_{0 j}, v_{0 j}, \pi_{0 j}\right)\right)_{1 \times 5}$ $=((1,0,0),(1,0,0), \ldots,(1,0,0))$.

Step 6: The distance compared to the reference series and the grey relational coefficients of the candidates are highlighted in the following table 5 .

Table 5

\begin{tabular}{|c|c|c|c|c|c|}
\hline \multicolumn{7}{|c|}{$\delta_{i j}$ VE $\zeta_{i j}$ VALUES OF THE CANDIDATES } \\
\hline$\delta_{i j}$ & $\mathbf{C}_{1}$ & $\mathbf{C}_{\mathbf{2}}$ & $\mathbf{C}_{\mathbf{3}}$ & $\mathbf{C}_{\mathbf{4}}$ & $\mathbf{C}_{5}$ \\
\hline$\delta_{1 j}$ & 0.75 & 0.5 & 0.5 & 0.5 & 0.35 \\
\hline$\delta_{2 j}$ & 0.75 & 0.35 & 0.35 & 0.35 & 0.5 \\
\hline$\delta_{3 j}$ & 0.5 & 0.35 & 0.5 & 0.5 & 0.35 \\
\hline$\delta_{4 j}$ & 0.35 & 0.35 & 0.35 & 0.35 & 0.5 \\
\hline$\delta_{5 j}$ & 0.5 & 0.75 & 0.5 & 0.5 & 0.35 \\
\hline$\delta_{6 j}$ & 0.5 & 0.35 & 0.75 & 0.5 & 0.35 \\
\hline$\delta_{\min }$ & & & 0.35 & & \\
\hline$\delta_{\max }$ & & & 0.75 & & \\
\hline$\xi_{i j}$ & $\mathbf{C}_{1}$ & $\mathbf{C}_{2}$ & $\mathbf{C}_{3}$ & $\mathbf{C}_{4}$ & $\mathbf{C}_{5}$ \\
\hline$\xi_{1 j}$ & 0.64 & 0.83 & 0.83 & 0.83 & 1 \\
\hline$\xi_{2 j}$ & 0.64 & 1 & 1 & 1 & 0.83 \\
\hline$\xi_{3 j}$ & 0.83 & 1 & 0.83 & 0.83 & 1 \\
\hline$\xi_{4 j}$ & 1 & 1 & 1 & 1 & 0.83 \\
\hline$\xi_{5 j}$ & 0.83 & 0.64 & 0.83 & 0.83 & 1 \\
\hline$\xi_{6 j}$ & 0.83 & 1 & 0.64 & 0.83 & 1 \\
\hline
\end{tabular}

Step 7: The grey relational grade values for the alternatives were determined using the weights obtained by the AHP method. The grey relational grades of the alternatives are as follows:

$$
\begin{aligned}
& \gamma_{1}=0.7898 ; \gamma_{2}=0.8884 ; \gamma_{3}=0.8796 ; \gamma_{4}=0.9878 \\
& \gamma_{5}=0.8004 ; \gamma_{6}=0.8378
\end{aligned}
$$

Step 8: All candidates are ranked according to their grey relational grades and the candidate with the highest score is determined to be the most suitable candidate for the company. According to the order stated below, the candidate number 4 (x4) is proven to be the most suitable candidate to be selected for the Spazio Company with regard to the determined criteria and method.

$$
\begin{aligned}
& \gamma_{4}>\gamma_{2}>\gamma_{3}>\gamma_{6}>\gamma_{5}>\gamma_{1} \\
& x_{4}>x_{2}>x_{3}>x_{6}>x_{5}>x_{1}
\end{aligned}
$$

\section{CONCLUSIONS, EVALUATION AND RECOMMENDATIONS}

Personnel selection is one of the important factors that directly influence the success of the companies. This choice is becoming more important especially in sectors such as apparel, where the intensity of labor stands in the forefront. The rapidly changing fashion sense in the apparel sector and the developing and differentiating consumer desires in this direction have led the design departments of the companies to be overhauled and managed with a more professional understanding. Considering these aspects, the selection of the fashion designers for apparel companies needs to be conducted with more scientific and objective methods, rather than conventional and intuitive methods.

In this study, the designer selection process of a local apparel company was analyzed. In this context, the most suitable designer candidate had been determined based on the interviews with the chief designer of the company who is also one of the second generation managers, as she is in charge for recruiting the designers. In this context, the criteria that play a role in the selection of designer were determined, in accordance with the activities and objectives of the company. The importance ratios of these criteria were determined via the method of AHP, in order to avoid inconsistency and misidentification of the ranking. The grey relational analysis method is commonly used in the literature to reveal the geometric similarities of the series compared with the reference series. The idea behind the grey relational analysis concept is that if an alternative has the highest grey relational grade between the reference sequence and itself, then the alternative becomes of the best choice for the solution. In this study, the grey relational analysis method was utilized in the selection of appropriate design department personnel on the basis of determined criteria.

The integrated usage of AHP and intuitionistic grey relational analysis methods has also been supported and proven by previous studies on being suitable and providing effective solutions to selection problems. Selection process studies to be carried out within this approach can be expanded to different departments and different sectors for the similar decision making problems, by enabling the contributions to the literature. 


\section{REFERENCES}

[1] Güngör, Z., Serhadlığlu, G., Kesen, S.E., A fuzzy AHP approach to personnel selection problem, In: Applied Soft Computing, 2009, 9, 641-646

[2] Dağdeviren, M., A hybrid multi-criteria decision-making model for personnel selection in manufacturing systems, In: Journal of Intelligent Manufacturing, 2010, 21, 451-460

[3] Vatansever, K., Oncel, M., An implementation of integrated multi-criteria decision making techniques for academic staff recruitment, In: Journal of Management, Marketing and Logistics, 2014, 1, 2, 111-126

[4] Zavadskas, E.K., Turskis, Z., Tamošaitiene, J., Marina, V., Multi criteria selection of project Managers by applying grey criteria, In: Technological and Economic Development of Economy, 2008, 14, 4, 462-477

[5] Mukhopadhyaya, D., Pramanik, S., Grey relational analysis based intuitionistic fuzzy multi-criteria group decision making approach for teacher selection in higher education, In: International Journal of Computer Applications, 2011, $34,21-29$

[6] Kundakcı, N., Personnel selection with grey relational analysis, In: Management Science Letters, 2016, 6, 351-360

[7] Bali, Ö., A dynamic multi criteria decision making model under uncertainities, In: Journal of the Faculty of Engineering and Architecture of Gazi University, 2014, 29, 1, 131-140

[8] Orhan, K., The personnel selection applications in Turkey and the formation of a personnel selection battery for textile sector, Ege University-Institute of Social Sciences, Doctoral Thesis, 2003

[9] Özlü, P., A research study on personal selection process in ready-to-wear sector, In: Tekstilve Konfeksiyon, 2006, 3, 200-205

[10] Şener, T., Analytical Hierarchy Process for the personnel selection problem: An implementation for the textile sector, Selçuk University-Institute of Social Sciences, Doctoral Thesis, 2011

[11] Kanat, S., Atılgan, T., Employee selection with Analytic Hierarchy Process in Clothing Sector: Turkish Case, In: International Conference on Engineering and Natural Sciences - ICENS 2015, 15-19 May 2015, Skopje Macedonia, 2015, 314-320

[12] Atanassov, K.T., Intuitionistic fuzzy sets, In: Fuzzy Sets and Systems, 1986, 20, 87-96

[13] Deng, J., Control problems of grey systems, In: Systems and Control Letters, 1982, 1, 5, 288-294

[14] Köse, E., Aplak, H.S., Kabak, M., An integrated approach based on grey system theory for personnel selection, In: Ege Academic Review, 2013, 13, 4, 461-471

[15] Mondal, K., Pramanik, S., Intuitionistic fuzzy multicriteria group decision-making approach to quality clay-brick selection problems based on grey relational analysis, In: Journal of Applied Quantitative Methods, 2014, 9, 2, 35-50, 2014

[16] Zhang, S., Liu, S., A GRA-based intuitionistic fuzzy multi-criteria group decision making method for personnel selection, In: Expert Systems with Applications, 2011, 38, 11401-11405

[17] Donegan, H., Dodd, F., McMaster, T., A new approach to AHP decision-making, In: The Statician, 1992, 41, 295-302

[18] Saaty, T.L., Decision making with the analytic hierarchy process, In: International Journal of Services Sciences, 2008, 1, 1, 83-98

\section{Authors:}

\section{Dr. PELIN OFLUOGLU KUCUK}

\section{Prof. Dr. TURAN ATILGAN}

Department of Textile Engineering, Engineering Faculty, Ege University, Bornova/lzmir, Turkey e-mail: pelin.ofluoglu@ege.edu.tr, turan.atilgan@ege.edu.tr

\section{Corresponding author:}

\section{PELIN OFLUOGLU KUCUK}

e-mail: pelinofluoglu@gmail.com 


\title{
Crimping analysis of textured polyester multifilament yarn
}

\author{
DOI: 10.35530/IT.070.05.1602
}

JOVANA STEPANOVIĆ

DUŠAN TRAJKOVIĆ

TATJANA ŠARAC

JOVAN STEPANOVIĆ

\section{ABSTRACT - REZUMAT}

\section{Crimping analysis of textured polyester multifilament yarn}

The properties of textured POY PES multifilament yarns are conditioned by texturing temperature, texturing speed, stretching degree and by the ratio of disc peripheral speed and yarn speed. In the paper attention is focused on crimping of yarns. New method for defining crimping limits is proposed. The method is based on the flow analysis of the force-elongation function. POY multifilament polyester yarns, having the fineness of $167 f 36 \times 1$ dtex were analyzed. The texturing of PES multifilament yarns was performed using different first heater temperatures $\left(350^{\circ} \mathrm{C}, 400^{\circ} \mathrm{C}, 450^{\circ} \mathrm{C}\right)$ and maintaining the constant temperature of the second heater $\left(180^{\circ} \mathrm{C}\right)$, then with different texturing speeds $(500 \mathrm{~m} / \mathrm{min}, 600 \mathrm{~m} / \mathrm{min}, 700 \mathrm{~m} / \mathrm{min}, 900 \mathrm{~m} / \mathrm{min}, 1000 \mathrm{~m} / \mathrm{min}, 1100 \mathrm{~m} / \mathrm{min})$, using different ratio of the disc circumferential speed to yarn speed $(2.15,2.20,2.25)$ and at the extension degree of 1.665 .

Keywords: texturing, multifilament, polyester, yarn, crimping

\section{Analiza ondulării firului multifilamentar din poliester texturat}

Proprietățile firelor multifilamentare texturate POY PES sunt condiționate de temperatura de texturare, viteza de texturare, gradul de întindere și raportul dintre viteza periferică a discului și viteza firelor. Acest studiu abordează ondularea firelor. Este propusă o nouă metodă pentru definirea limitelor de ondulare. Metoda se bazează pe analiza funcției forță-alungire. Au fost analizate firele de poliester multifilamentar POY, cu finețea de 167f36x1 dtex. Texturarea firelor multifilamentare PES a fost efectuată folosind diferite temperaturi ale primului încălzitor $\left(350^{\circ} \mathrm{C}, 400^{\circ} \mathrm{C}, 450^{\circ} \mathrm{C}\right)$ și menținerea temperaturii constante a celui de-al doilea încălzitor $\left(180^{\circ} \mathrm{C}\right)$, apoi cu viteze de texturare diferite (500 m/min, $600 \mathrm{~m} / \mathrm{min}, 700 \mathrm{~m} / \mathrm{min}, 900 \mathrm{~m} / \mathrm{min}, 1000 \mathrm{~m} / \mathrm{min}, 1100 \mathrm{~m} \mathrm{~min})$, folosind raportul diferit dintre viteza circumferențială a discului și viteza firelor $(2,15 ; 2,20 ; 2,25)$ și un grad de extensie de 1,665.

Cuvinte-cheie: texturare, multifilament, poliester, fir, ondulare

\section{INTRODUCTION}

Texturing is a technological process for the transformation of smooth fibrous structures into the crimped, creating permanent deformations of monofilaments. Multifilamant yarns of thermoplastic fibers are texturized, when crimps are mainly shaped by a combination of heat and mechanical action. Such transformation process increases voluminousness and elasticity, the yarn is softer and more pleasant to touch, and the product made of such yarn is thermo-physiologically comfortable.

In the texturization process, the yarn is exposed to the influence of high temperatures and the tensile and torsion forces, which affects the structure of the yarn and, consequently, its properties [1-3].

Using HT heaters (high temperature contactless heaters) steps have been taken to improve the texturing process, with the aim of increasing productivity while preserving the quality of textured yarn. Increasing the temperature of the heaters results in more intensive warming of the yarn, which in turn requires a shortening of the retention time of the yarn in the heater and consequently a temperature drop over the cross-section of the thread [4-5].

A considerable number of papers deals with the analysis of the properties of textured yarn of extruded polyester filaments (FOY - Fully Oriented Yarn) characterized by a stable structure [6-8].

Papers studying the properties of textured yarns, of partially oriented polyester filaments (POY), were mainly originated by analyzing yarns formed in laboratory conditions [9-11]. Investigation of crimping [12] of textured multifilament yarns produced in industrial conditions [13] indicate that optimal texture parameters must be chosen as a compromise solution.

Since textured filament yarns formed from POY PES filaments produced on machines with HT heaters have not been sufficiently studied, the study of the influence of some parameters of the texturing process on the properties of textured yarns in the zone of elastic deformations is presented in this paper. The elastic deformation zone ends with the yield point [14]. That zone also includes the crimping [15] of textured yarns, which is one of the key characteristics of these yarns. Therefore, in the paper is presented 
analyzes the crimping of textured POY PES multifilament yarns. A conventional (standardized) method was used for the analysis [16], but a new method based on the analysis of the flow function of the force-elongation of these yarns was proposed.

\section{MATERIALS AND METHODS}

Preparation of experimental material was done under industrial conditions on a machine for stretching texturing with high temperature heater: FTF-15 (ICBT, France). Technical characteristics of the machine are: maximum texturing speed - $1500 \mathrm{~m} / \mathrm{min}$; the length of the first heater $-1.050 \mathrm{~m}$; the length of the second heater - $1.60 \mathrm{~m}$; cooling zone: $1.24 \mathrm{~m}$; friction aggregate - ICBT aggregate 1-5-1; working PU discs (5 pcs); C profile.

Prepared were samples of textured PES yarn of fineness $167 f 36 \times 1$ dtex, of POY PES multifilament fineness $278 f 36 \times 1$ dtex, from the manufacturer TWD Fibers (Germany). POY polyester filament (poly (ethylene terephthalate)) used in this investigation was partially oriented with very low crystallinity degree (less than $5 \%$ ), so that its structure and properties could be changed to a great extent by changing texturing process parameters.

In the texturing process of yarns various temperatures of the first heater were used $\left(350^{\circ} \mathrm{C}, 400^{\circ} \mathrm{C}\right.$ and $450^{\circ} \mathrm{C}$ ) at constant temperature of the second heater $\left(180^{\circ} \mathrm{C}\right)$, then at different texturing speeds (500 $\mathrm{m} / \mathrm{min}$ to $1100 \mathrm{~m} / \mathrm{min}$ ), with the stretching degree of 1.665 and at different $\mathrm{D} / \mathrm{Y}$ ratio $(2.15,2.20$ and 2.25).

A standardized method according to DIN 53840-1 [16] was applied for the analysis of the crimping of textured PES multifilament yarns.

In addition, in order to contribute to the development of a new method for determining the curvature, a method based on the analysis of flow of the forceelongation of textured multilayer yarns was presented.

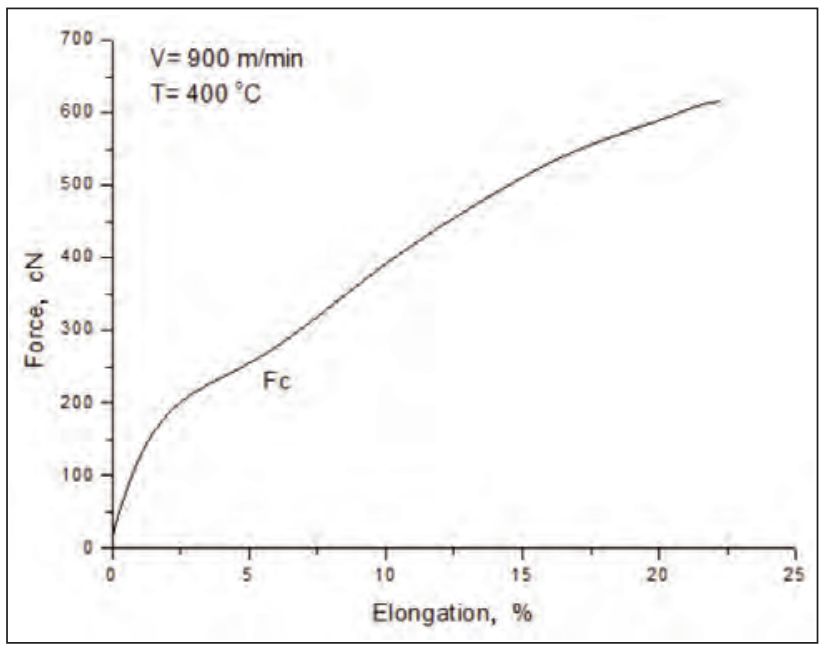

a
For determination of characteristics of experimental materials, automatic dynamometer USTER TENSORAPID 4 was used (DIN 53384).

Crimping limits of textured PES yarns were determined by analyzing $F(\varepsilon)$ function. Figure 1 shows the first derivative of $F(\varepsilon)$ function, on the basis of which force intensities and the values of relative elongation at the crimping limit of analyzed texture PES yarns were determined.

Further, using the results obtained determined was the work of the force to the crimping limit. The work of the force was defined by the surface under forceelongation curve to the limits defined by the flow analysis of that function [17].

\section{RESULTS AND DISCUSSION}

Results obtained by analysis of textured PES multifilament yarns are shown in tables 1 to 3 .

Tables 1-3 show the texture parameters and some characteristics of the analyzed textured POY PES multifilament yarn $\left(v_{i}-\right.$ texture speed $-\mathrm{m} / \mathrm{min} ; T-$ temperature of primary heaters $-{ }^{\circ} \mathrm{C}$; $\mathrm{Cc}$ - characteristic crimp - \%; $F_{r}$ - relative breaking force $-\mathrm{cN} / \mathrm{tex}$; $\varepsilon$ - relative breaking elongation $-\% ; F_{c}$ - force to the crimping limit $-\mathrm{cN} ; \varepsilon_{c}-$ elongation at the crimping limit $-\% ; A_{c}-$ work of the force to the crimping limit $-\mathrm{cN} \mathrm{cm}$.

Figures 2 to 4 show the graphs of the trend of changes in characteristic crimp (Cc) and elongation at the crimping limit $\left(\varepsilon_{c}\right)$ at different texturing speeds, different temperatures of primary heaters and different $\mathrm{D} / \mathrm{Y}$ values.

In most cases, analogue changes of the analyzed parameters of textured multifilament yarns can be noted (figures 2 to 4 ).

During yarn stretching, first the straightening of crimps, formed in the texturing process takes place. In the beginning, a higher curve slope can be noticed, due to faster force increase with regard to elongation of textured PES yarn (figure 1,a). This can be the effect of monofilament interlacing which appears in

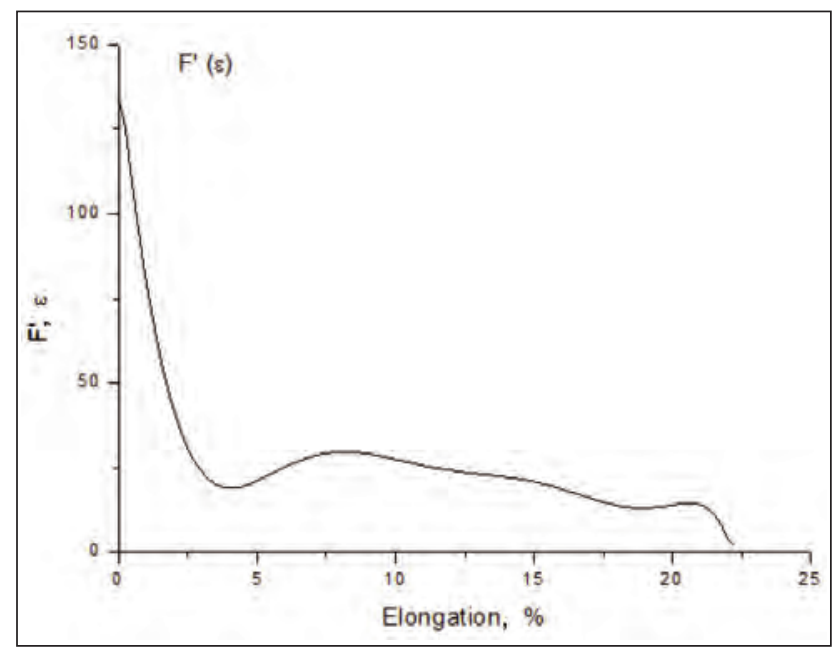

b

Fig. 1. Typical $F-\varepsilon$ curves (a) and the first $F^{\prime}(\varepsilon)$ derivative (b) of the function 


\begin{tabular}{|c|c|c|c|c|c|c|c|c|c|c|}
\hline \multicolumn{8}{|c|}{ RESULTS OF ANALYSIS OF TEXTURED PES MULTIFILAMENT YARN (D/Y = 2.15) } \\
\hline $\begin{array}{c}\text { Sample } \\
\text { no. }\end{array}$ & $\begin{array}{c}\mathrm{V} \\
(\mathrm{m} / \mathrm{min})\end{array}$ & $\begin{array}{c}\mathrm{T} \\
\left({ }^{\circ} \mathrm{C}\right)\end{array}$ & $\begin{array}{c}\mathrm{Cc} \\
(\%)\end{array}$ & $\begin{array}{c}\mathrm{Fr} \\
(\mathrm{cN} / \mathrm{tex})\end{array}$ & $\begin{array}{c}\mathrm{CV} \\
\mathrm{Fr}\end{array}$ & $\begin{array}{c}\varepsilon \\
(\%)\end{array}$ & $\begin{array}{c}\mathrm{CV} \\
\varepsilon\end{array}$ & $\begin{array}{c}\mathrm{F}_{\mathrm{c}} \\
(\mathrm{cN})\end{array}$ & $\begin{array}{c}\varepsilon_{\mathrm{C}} \\
(\%)\end{array}$ & $\begin{array}{c}\mathrm{A}_{\mathrm{c}} \\
(\mathrm{cN} \mathrm{cm})\end{array}$ \\
\hline 1 & 1100 & 350 & 9.2 & 34.2 & 4.4 & 19.2 & 9.2 & 222.27 & 2.90 & 217.70 \\
\hline 2 & 1000 & 350 & 12.5 & 36.0 & 5.8 & 20.9 & 13.2 & 252.87 & 3.48 & 295.74 \\
\hline 3 & 900 & 350 & 17.6 & 36.2 & 3.1 & 27.0 & 6.6 & 226.65 & 3.97 & 320.44 \\
\hline 4 & 700 & 350 & 11.5 & 36.5 & 2.9 & 24.6 & 6.9 & 213.12 & 3.75 & 291.41 \\
\hline 5 & 600 & 350 & 10.9 & 36.5 & 2.7 & 26.4 & 7.2 & 206.15 & 3.83 & 288.46 \\
\hline 6 & 500 & 350 & 14.3 & 37.8 & 3.2 & 25.2 & 8.9 & 216.54 & 4.32 & 319.10 \\
\hline 7 & 1100 & 400 & 9.4 & 34.3 & 5.3 & 18.6 & 11.3 & 220.39 & 3.28 & 234.29 \\
\hline 8 & 1000 & 400 & 15.3 & 36.5 & 6.0 & 21.2 & 14.4 & 238.84 & 3.41 & 269.45 \\
\hline 9 & 900 & 400 & 18.1 & 37.3 & 2.9 & 25.7 & 6.2 & 233.43 & 4.32 & 343.93 \\
\hline 10 & 700 & 400 & 19.5 & 38.4 & 3.0 & 26.3 & 5.6 & 216.53 & 4.29 & 311.90 \\
\hline 11 & 600 & 400 & 15.5 & 37.8 & 2.6 & 25.9 & 5.8 & 215.31 & 4.27 & 314.19 \\
\hline 12 & 500 & 400 & 18.9 & 38.3 & 3.7 & 24.7 & 8.2 & 216.46 & 4.90 & 332.77 \\
\hline 13 & 1100 & 450 & 13.7 & 37.4 & 6.9 & 21.4 & 12.4 & 219.89 & 2.88 & 211.17 \\
\hline 14 & 1000 & 450 & 15.0 & 37.8 & 5.6 & 25.5 & 12.5 & 207.03 & 3.22 & 219.07 \\
\hline 15 & 900 & 450 & 19.6 & 37.9 & 2.8 & 25.6 & 5.9 & 215.46 & 4.38 & 306.84 \\
\hline 16 & 700 & 450 & 20.0 & 38.8 & 2.5 & 26.0 & 6.1 & 210.01 & 4.26 & 298.05 \\
\hline 17 & 600 & 450 & 16.5 & 38.9 & 2.6 & 26.0 & 5.6 & 209.62 & 4.54 & 300.30 \\
\hline 18 & 500 & 450 & 26.3 & 39.6 & 1.8 & 25.4 & 5.2 & 210.19 & 4.21 & 293.38 \\
\hline
\end{tabular}

Table 2

\begin{tabular}{|c|c|c|c|c|c|c|c|c|c|c|}
\hline \multicolumn{8}{|c|}{ RESULTS OF ANALYSIS OF TEXTURED PES MULTIFILAMENT YARN (D/Y = 2.20) } \\
\hline $\begin{array}{c}\text { Sample } \\
\text { no. }\end{array}$ & $\begin{array}{c}\mathrm{V} \\
(\mathrm{m} / \mathrm{min})\end{array}$ & $\begin{array}{c}\mathrm{T} \\
\left({ }^{\circ} \mathrm{C}\right)\end{array}$ & $\begin{array}{c}\mathrm{Cc} \\
(\%)\end{array}$ & $\begin{array}{c}\mathrm{Fr} \\
(\mathrm{cN} / \mathrm{tex})\end{array}$ & $\begin{array}{c}\mathrm{CV} \\
\mathrm{Fr}\end{array}$ & $\begin{array}{c}\varepsilon \\
(\%)\end{array}$ & $\begin{array}{c}\mathrm{CV} \\
\varepsilon\end{array}$ & $\begin{array}{c}\mathrm{F}_{\mathrm{c}} \\
(\mathrm{cN})\end{array}$ & $\begin{array}{c}\varepsilon_{\mathrm{c}} \\
(\%)\end{array}$ & $\begin{array}{c}\mathrm{A}_{\mathrm{c}} \\
(\mathrm{cN} \text { cm })\end{array}$ \\
\hline 19 & 1100 & 350 & 9.1 & 34.6 & 5.4 & 19.8 & 11.4 & 234.00 & 3.11 & 247.6 \\
\hline 20 & 1000 & 350 & 12.5 & 35.2 & 6.0 & 20.7 & 12.1 & 249.14 & 3.42 & 291.2 \\
\hline 21 & 900 & 350 & 13.5 & 35.9 & 3.9 & 27.8 & 7.2 & 222.92 & 3.87 & 311.6 \\
\hline 22 & 700 & 350 & 10.7 & 36.8 & 4.2 & 25.0 & 7.7 & 212.45 & 4.02 & 302.5 \\
\hline 23 & 600 & 350 & 11.7 & 37.0 & 2.0 & 26.4 & 4.4 & 211.24 & 3.95 & 296.4 \\
\hline 24 & 500 & 350 & 14.1 & 38.0 & 3.1 & 25.0 & 8.2 & 214.34 & 4.11 & 305.2 \\
\hline 25 & 1100 & 400 & 10.4 & 35.4 & 5.6 & 19.6 & 10.3 & 223.04 & 3.02 & 223.8 \\
\hline 26 & 1000 & 400 & 15.0 & 36.3 & 14.0 & 20.6 & 11.9 & 233.09 & 3.28 & 258.2 \\
\hline 27 & 900 & 400 & 17.7 & 37.0 & 3.4 & 26.9 & 8.3 & 236.41 & 4.06 & 337.1 \\
\hline 28 & 700 & 400 & 21.5 & 38.7 & 2.3 & 25.8 & 6.4 & 218.33 & 4.53 & 320.2 \\
\hline 29 & 600 & 400 & 15.4 & 38.0 & 2.7 & 26.2 & 5.3 & 216.11 & 4.13 & 308.1 \\
\hline 30 & 500 & 400 & 20.4 & 38.7 & 3.8 & 26.0 & 7.4 & 203.13 & 4.54 & 293.3 \\
\hline 31 & 1100 & 450 & 12.6 & 35.9 & 8.0 & 21.5 & 16.5 & 226.03 & 3.38 & 250.4 \\
\hline 32 & 1000 & 450 & 15.7 & 36.9 & 6.4 & 21.0 & 11.4 & 227.61 & 3.77 & 271.6 \\
\hline 33 & 900 & 450 & 20.8 & 38.4 & 2.4 & 26.6 & 6.3 & 222.45 & 4.83 & 340.8 \\
\hline 34 & 700 & 450 & 20.1 & 39.4 & 2.6 & 26.0 & 6.0 & 217.36 & 4.48 & 317.4 \\
\hline 35 & 600 & 450 & 17.3 & 38.7 & 1.9 & 26.3 & 4.7 & 190.33 & 4.29 & 263.4 \\
\hline 36 & 500 & 450 & 26.5 & 39.0 & 3.3 & 25.1 & 6.5 & 208.25 & 4.07 & 283.0 \\
\hline
\end{tabular}

the process of false twisting, because not all monofilaments are heated to the same temperature due to the position in multifilament yarn and therefore do not receive the same torsion energy. During further stretching, releasing of interlaced monofilaments takes place and to the point $F_{c}$ (the point of crimp straightening point) decline of the slope of force elongation function can be seen. At this point recorded is the force needed for crimp straightening $\left(F_{c}\right)$ and also corresponding elongation $(\varepsilon)$. The force $F_{c}$ 


\begin{tabular}{|c|c|c|c|c|c|c|c|c|c|c|}
\hline \multicolumn{10}{|c|}{ RESULTS OF ANALYSIS OF TEXTURED PES MULTIFILAMENT YARN (D/Y = 2.25) } \\
\hline $\begin{array}{c}\text { Sample } \\
\text { no. }\end{array}$ & $\begin{array}{c}\mathrm{v} \\
(\mathrm{m} / \mathrm{min})\end{array}$ & $\begin{array}{c}\mathrm{T} \\
\left({ }^{\circ} \mathrm{C}\right)\end{array}$ & $\begin{array}{c}\mathrm{Cc} \\
(\%)\end{array}$ & $\begin{array}{c}\mathrm{Fr} \\
(\mathrm{cN} / \mathrm{tex})\end{array}$ & $\begin{array}{c}\mathrm{CV} \\
\mathrm{Fr}\end{array}$ & $\begin{array}{c}\varepsilon \\
(\%)\end{array}$ & $\begin{array}{c}\mathrm{CV} \\
\varepsilon\end{array}$ & $\begin{array}{c}\mathrm{F}_{\mathrm{c}} \\
(\mathrm{cN})\end{array}$ & $\begin{array}{c}\varepsilon_{\mathrm{c}} \\
(\%)\end{array}$ & $\begin{array}{c}\mathrm{A}_{\mathrm{c}} \\
(\mathrm{cN} \mathrm{cm})\end{array}$ \\
\hline 37 & 1100 & 350 & 10.2 & 34.3 & 4.8 & 19.4 & 10.0 & 221.15 & 3.10 & 225.86 \\
\hline 38 & 1000 & 350 & 12.5 & 36.1 & 6.5 & 20.4 & 13.1 & 257.45 & 3.67 & 330.14 \\
\hline 39 & 900 & 350 & 13.7 & 35.8 & 2.8 & 27.3 & 6.8 & 218.61 & 3.78 & 304.28 \\
\hline 40 & 700 & 350 & 10.6 & 35.9 & 3.1 & 24.6 & 6.7 & 214.92 & 4.02 & 313.69 \\
\hline 41 & 600 & 350 & 12.0 & 37.0 & 1.6 & 25.8 & 3.9 & 216.34 & 4.12 & 317.33 \\
\hline 42 & 500 & 350 & 14.6 & 38.2 & 3.3 & 25.9 & 9.3 & 211.98 & 4.08 & 299.57 \\
\hline 43 & 1100 & 400 & 10.1 & 35.6 & 5.7 & 19.1 & 11.0 & 216.26 & 2.75 & 199.03 \\
\hline 44 & 1000 & 400 & 13.9 & 37.3 & 5.2 & 22.1 & 12.3 & 256.05 & 3.57 & 307.16 \\
\hline 45 & 900 & 400 & 18.0 & 36.7 & 3.1 & 26.5 & 7.4 & 221.62 & 4.04 & 315.28 \\
\hline 46 & 700 & 400 & 16.5 & 37.9 & 2.0 & 25.3 & 6.9 & 190.92 & 4.07 & 254.69 \\
\hline 47 & 600 & 400 & 15.9 & 38.3 & 1.6 & 26.5 & 4.9 & 212.98 & 4.42 & 322.55 \\
\hline 48 & 500 & 400 & 20.4 & 38.7 & 2.3 & 24.6 & 6.4 & 216.50 & 4.47 & 319.97 \\
\hline 49 & 1100 & 450 & 11.3 & 41.4 & 7.0 & 20.7 & 12.5 & 200.31 & 2.72 & 185.66 \\
\hline 50 & 1000 & 450 & 14.5 & 36.0 & 7.8 & 20.9 & 15.2 & 226.14 & 4.21 & 291.62 \\
\hline 51 & 900 & 450 & 20.4 & 38.1 & 2.9 & 25.7 & 7.6 & 224.93 & 4.45 & 330.48 \\
\hline 52 & 700 & 450 & 20.2 & 38.6 & 2.5 & 25.6 & 5.5 & 204.31 & 4.14 & 281.16 \\
\hline 53 & 600 & 450 & 17.5 & 38.8 & 2.9 & 26.0 & 3.9 & 198.31 & 4.25 & 272.41 \\
\hline 54 & 500 & 450 & 27.0 & 39.4 & 3.0 & 25.6 & 7.0 & 200.53 & 3.99 & 268.82 \\
\hline
\end{tabular}

is determined on the basis of the force-elongation graph at the point of local minimum of the first derivative of the function (figure $1, b$ ).

The results obtained show the decline of yarn elongation with increase of texturing speed. It can be concluded that higher texturing speed negatively affects the crimping properties of textured PES yarn (figure 2 , a to $4, b$ ). At speeds over $900 \mathrm{~m} / \mathrm{min}$ a considerable reduction of yarn crimping is observed. However, in relation to the peripheral disk velocity and the yarn speed of 2.25, it is noted that the crimp decreases at texturing speed greater than $1000 \mathrm{~m} / \mathrm{min}$ (figure $4, b$ ). This picture confirms the finding that a higher $D / Y$

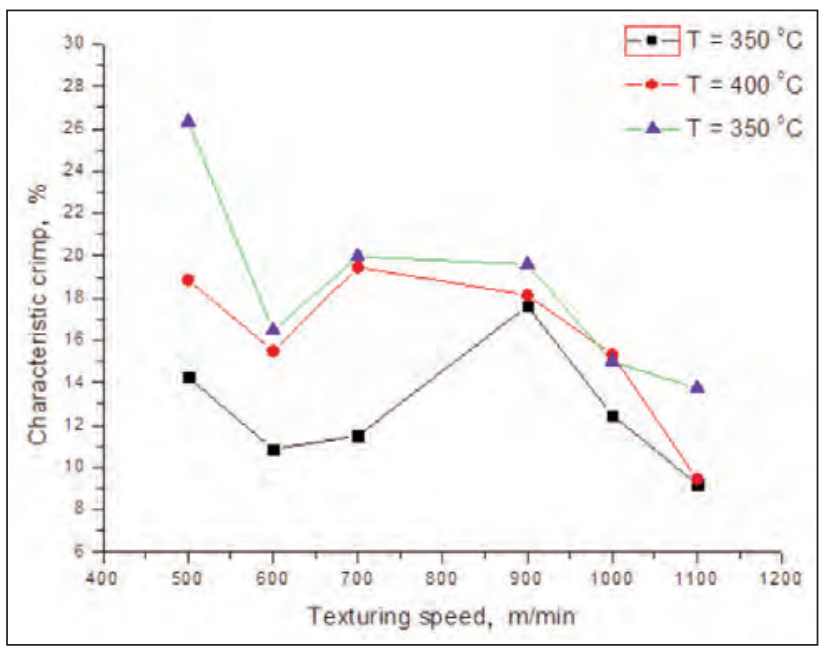

a ratio contributes to the greater crimp of textured PES yarns.

At the same time, elongation results show that yarns textured at higher temperature have higher crimping compared to yarns textured at lower temperature. Namely, increasing yarn temperature weakens intermolecular interactions resulting in increased mobility and flexibility of macromolecular chains and structural elements enabling easier formation of ordered structures - crystallities. Individual results deviations from expected results can be the effect of yarn being damaged at lower speeds and higher texturing temperatures. Moreover, POY polyester filament yarn in

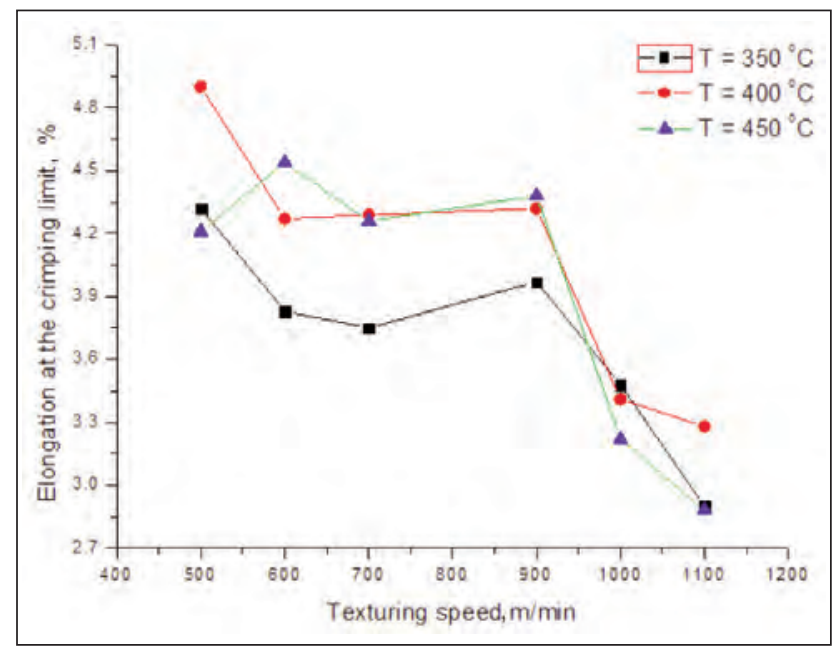

b

Fig. 2. Characteristic crimp (a) and elongation at the crimping limit (b) $D / Y 2.15$ 


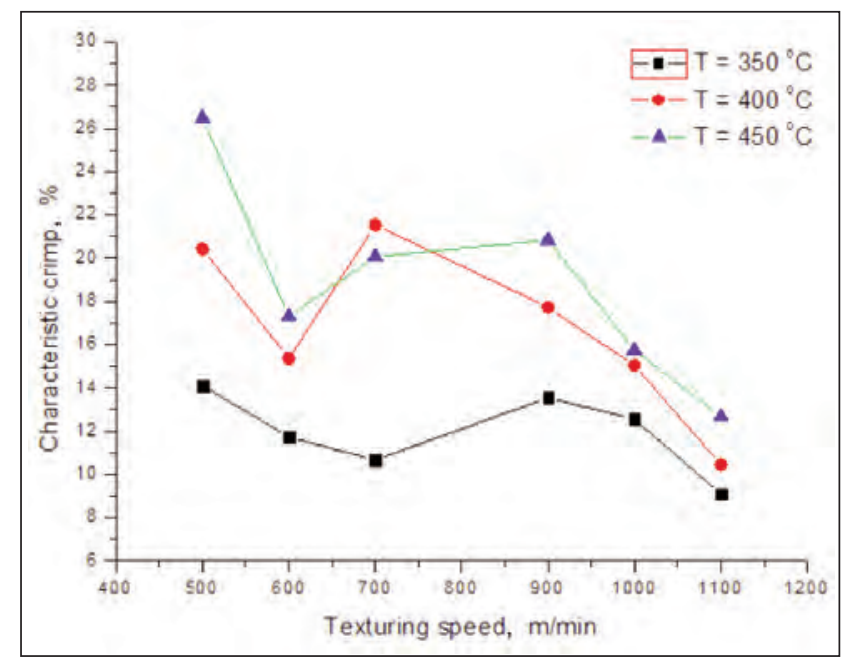

a

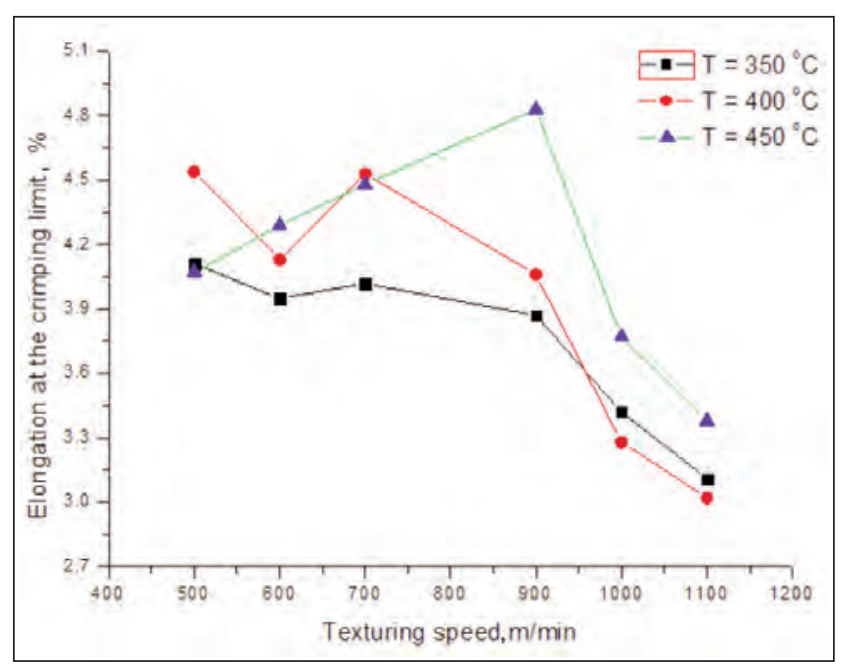

b

Fig. 3. Characteristic crimp (a) and elongation at the crimping limit (b) $D / Y 2.20$

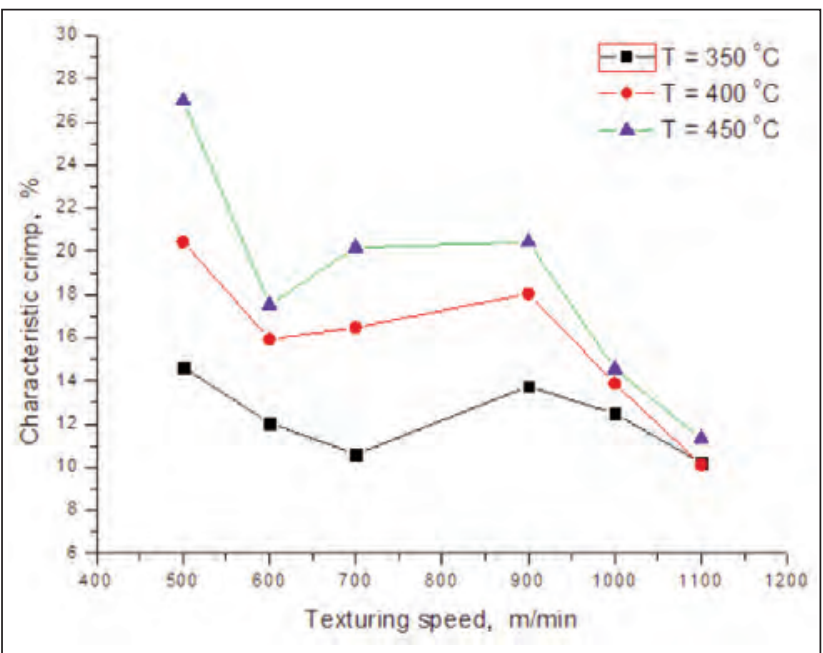

a

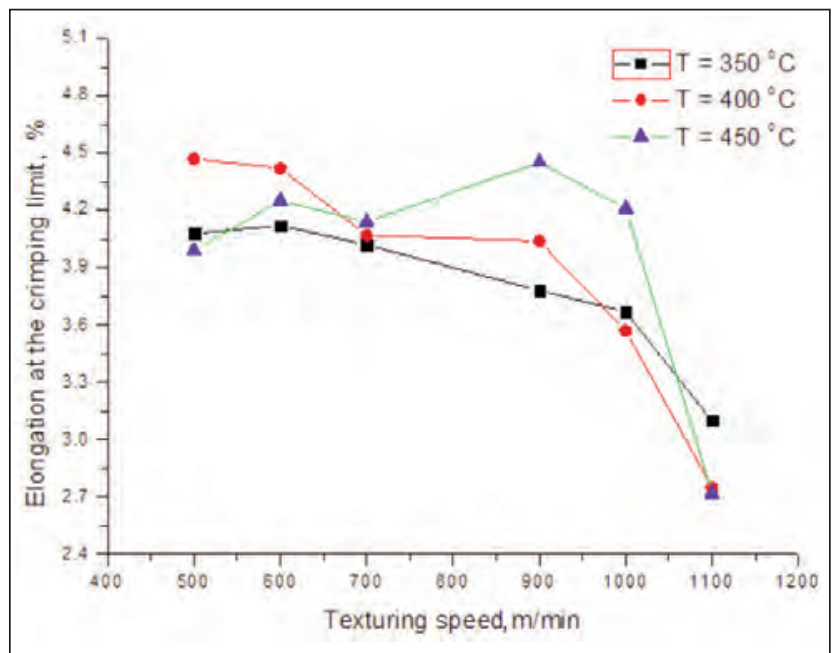

$\boldsymbol{b}$

Fig. 4. Characteristic crimp (a) and elongation at the crimping limit (b) $D / Y 2.25$

the process of texturing by false twisting is exposed to the action of both external stretching and twisting forces and internal straining, i.e. contraction due to relaxation processes and increased molecules mobility due to increased temperature. The ability of yarn to resist these force actions depends on the changes in yarn temperature determined by texturing speed and heater temperature. The influence of these two parameters on the straining in yarn is opposed, i.e. by increasing the texturing temperature the breaking of intermolecular interactions is easier and material softens resulting in lowering yarn straining, while by increasing texturing speed the external forces acting on yarn and internal straining in yarn increase. The detected results deviations from the expected can also be the result of the fact that textured multifilament yarns consist of a large number of individual filament threads entering the heater as a thick and compact beam. In that way the migration of individual threads in the twisted filament beams prevented, in the texturing zone. This leads to uneven temperature distribution (temperature gradient) over the filament yarn cross section (filament threads on the outside surface of the beam will receive more heat than the threads inside the beam) and to asymmetric stretching so that twisting forces distribution is therefore reflected on the crimping of individual threads in multifilament.

Interesting results offer the values of force work to the crimping limit and to the elasticity limit. Figure 5 shows the influence of texturing speed and temperature of the first heater on the force work to the crimping limit.

The results show that at texturing speeds higher than $900 \mathrm{~m} / \mathrm{min}$, force work values to the crimping limit and force work values decline (figures 5 , $a$ and $b, \mathrm{D} / \mathrm{Y}$ 2.15 and 2.20). However, the force work to the boundary of crimp in the multifilament yarn produced at a ratio $\mathrm{D} / \mathrm{Y}$ of 2.25 decreases at a texture speed greater than $1000 \mathrm{~m} / \mathrm{min}$ (figure 5, c, D/Y 2.25).

At high texturing speeds, yarn retention time in the heater is shorter; the yarn is less and unevenly heated from outside surface towards the core and therefore 


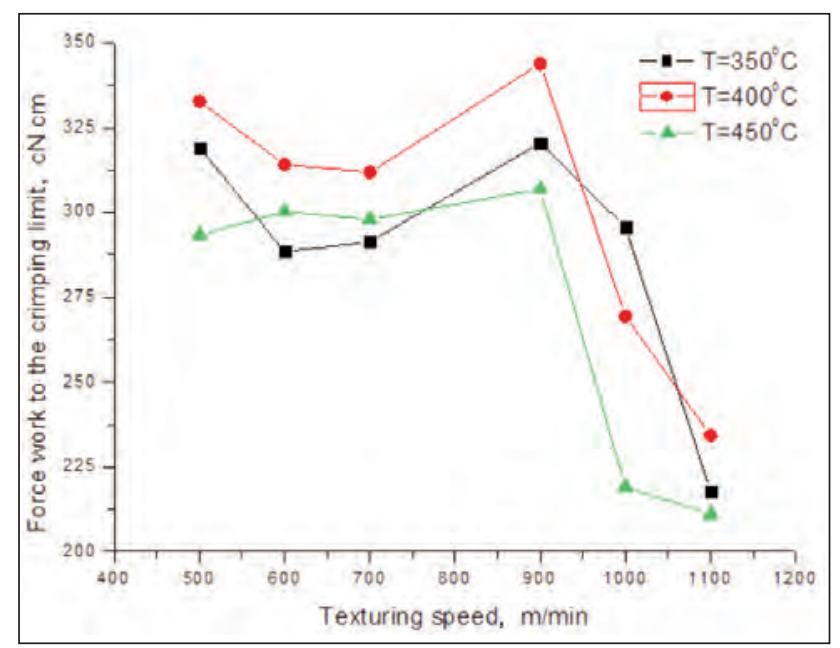

a

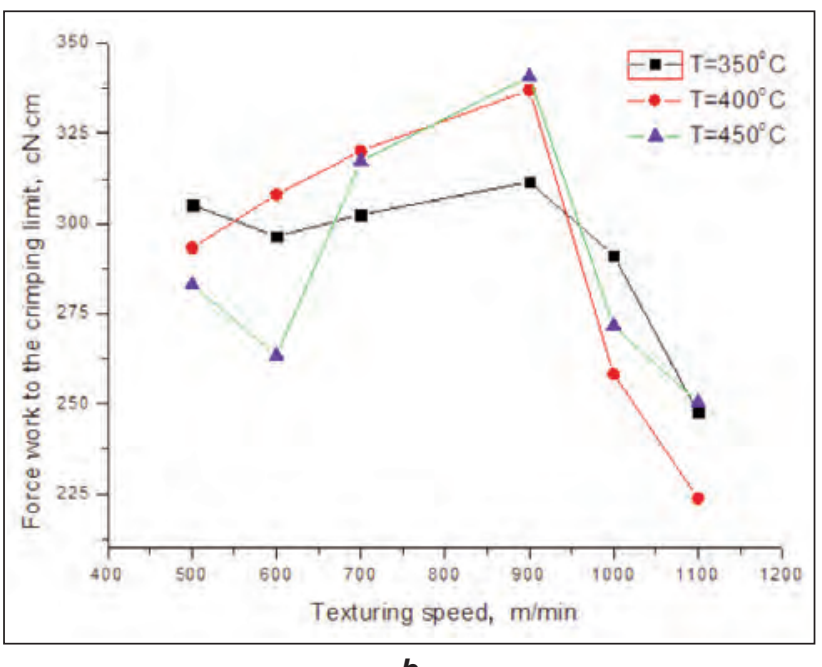

b

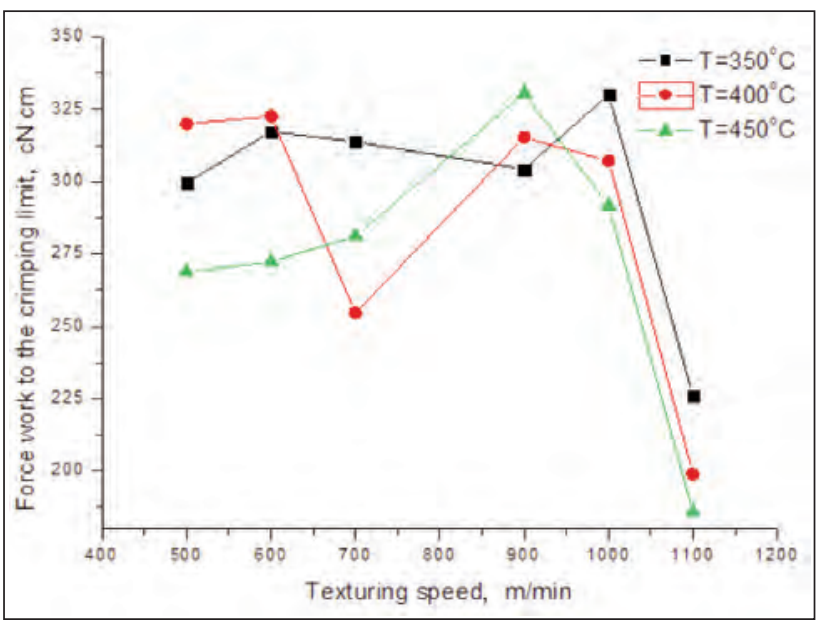

c

Fig. 5. The force work to the crimping limit $(a-\mathrm{D} / \mathrm{Y}=2.15 ; b-\mathrm{D} / \mathrm{Y}=2.20 ; c-\mathrm{D} / \mathrm{Y}=2.25)$ of textured PES filament yarns in the process of stretching the orientation of molecular chains in filaments is more uneven. On the other hand, lower texturing speeds and higher temperatures damage the yarn also having a negative effect on the quality of textured yarns

Retention time and temperature during yarn heating have an influence on the mutual position of molecular chains striving to the equilibrium state in filament which is in direct relation with the natural tendency of all physical systems to have the minimum potential energy.

Texture speed is a very important parameter from the aspect of productivity of the process, but also the quality of the produced yarns. The obtained results of the coefficient of variation of the relative breaking force and the elongation at break (tables 1 to 3 ) indicate a significant increase of deviation of the results of the analyzed yarn parameters ( $C V$ value) with increasing texturing speed. Therefore, the texturing process parameters must be carefully selected, with the aim of achieving high productivity and high quality of produced yarns.

\section{CONCLUSIONS}

Analyzing the flow of force-elongation function significant data can be obtained showing the properties of textured yarns, and the effect of individual process parameters on the properties. Analyzing parameters of textured yarn in the zone of elastic deformations it is possible to obtain information on voluminosity and elasticity of these yarns which represent a special interest for further yarn processing to final textile materials.

The analysis is based on the fact that the monofilament of multifilament yarn begins to provide a more uniform resistance to stretching forces after correcting the crimps formed in the texturing process. The given point, on the force-elongation graph, represents the boundary of the crimping and is defined by the minimum of the first derivative of the function.

Since the zone of elastic deformation is an insufficiently explored area of textured PES yarn, the investigation had the primary goal to propose methods of characteristics analysis of textured PES filament yarns by interpretation of force-elongation function flow. This of analysis of textured yarn characteristics can be a starting point for development of new methods for prediction of characteristics of textured filament yarns according to the future purpose.

\section{REFERENCES}

[1] Hearle, J.W.S., Hollick, L., Wilson, D.K., Yarn texturing technology, In: Woodhead Publishing Limited, Cambridge, 2001

[2] Atkinson, C., False twist textured yarns. Principles, processing and applications, In: Woodhead Publishing Limited, Cambridge, 2012

[3] Trajkovic, D., Savic, M., Kostic, M., Majstorovic, D., Stojanovic, P., Stepanovic, J., Dependence of structural characteristics of polyamide textured yarns on the parameters of the false twist yarn texturing process, In: Fibres \& Textiles in Eastern Europe, 2017, 25, 3, 79-85 
[4] Eskin, N., Analysis of a high temperature heater in a false twist texturing process, In: Energy Conversion and Management, 2003, 44, 16, 2531-2547

[5] Dupeuble, J.C., Texturing performance of polyamide yarn on high temperature heaters, In: Chemiefasern Textilindustrie, 1993, 43, 11, E145-E152

[6] Celik, P., Ozdil, N., Supure, G., Experimental investigation on the static and dynamic strength of false twist textured polyester yarns, In: Industria Textila, 2011, 62, 1, 38-43

[7] Shaikh, T.N., Bhattacharya, S.S., Deriving an empirical formula to determine the optimum level of false-twist in mechanically-crimped textured polyester yarn, In: Textile Research Journal, 2011, 81, 1995-2005

[8] Mahish S.S., Punj S.K., Kothari V.K, Comfort and handle related properties of PN blended air-jet textured yarn fabrics, In: Fibers and Polymers, 2010, 11. 6, 932-940

[9] Yildirim, K., Altun, S., Ulcay, Y., Relationship between yarn properties and process parameters in false-twist textured yarn, In: J. Engineered Fibers and Fabrics, 2009, 4, 2, 26-32

[10] Tehran, M.A., Azimi, B., Mojtahedi, M.R.M., Investigating the effect of false twist texturing process on the color coordinates variation of spun-dyed polyester filament yarns, In: J. Engineered Fibers and Fabrics, 2011, 6, 4, 54-62

[11] Karakaşa, C., Dayığlu, H., Influence of false-twist texturing parameters on the structural properties of polyester yarn, In: Indian Journal of Fibre \& Textile Research, 2005, 30, 1, 37-41

[12] Stojanovic, P., Savic, M., Trajkovic, D., Stepanovic, J., Stamenkovic, M., Kostic, M., The effect of false-twist texturing parameters on the structure and crimp properties of polyester yarn, In: Chemical Industry \& Chemical Engineering Quarterly, 2017, 23, 3, 411-419

[13] Savic, M., Trajkovic, D., Stepanovic, J., Stojanovic, P., Kostic, M., Majstorovic, D., Influence of heater temperature and texturing speed on the physical-mechanical properties of polyamide textured yarns in false-twist texturing process, In: Industria Textila, 2017, 68, 6, 451-457, http://doi.org/10.35530/IT.068.06.1482

[14] Stojanović, P., Trajković, D., Stepanović, J., Radmanovac, N., Stepanović, J., The influence of texturing process parameters on yield points and breaking forces of PES filament yarns, In: Industria Textila, 2018, 69, 4, 281-286, http://doi.org/10.35530/IT.069.04.1466

[15] Stepanović, J., Trajković, D., Ćirković, N., Radmanovac, N., A new method for the determination of a crimping degree of textured pes filament yarns, In: Advanced technologies, 2018, 7, 1, 69-73

[16] DIN 53840-1, Determination of parameters for the crimp of textured filament yarns; filament yarns with a linear density exceeding 500 dtex, 1983

[17] Hacioğullari, S.Ö, Babaarslan O., An investigation on the properties of polyester textured yarns produced with different fiber cross-sectional shapes, In: Industria Textila, 2018, 69, 4, 270-276, http://doi.org/10.35530/ IT.069.04.1281

Authors:

JOVANA STEPANOVIĆ, TATJANA ŠARAC, NATAŠA RADMANOVAC, DUŠAN TRAJKOVIĆ, JOVAN STEPANOVIĆ

Faculty of Technology, University of Niš/Bulevar oslobođenja 124, 16000 Leskovac, Serbia e-mail: stepanovicjovana@yahoo.com, tangerine.art83@gmail.com, radmanovac@tf.ni.ac.rs, dusan@tf.ni.ac.rs, jovan@tf.ni.ac.rs

Corresponding author:

JOVAN STEPANOVIĆ

e-mail: jovan@tf.ni.ac.rs 


\title{
Adhesion improvement at polyester fabric-silicone rubber interface by plasmas of argon and air to obtain conveyor belt
}

\author{
DOI: 10.35530/IT.070.05.1501B
}

\section{ABSTRACT - REZUMAT}

\section{Adhesion improvement at polyester fabric-silicone rubber interface by plasmas of argon and air to obtain conveyor belt}

Conveyor belt production requires good adhesion between coating layer and fabrics. Adhesion is important for good mechanical properties of belts. Silicone rubber has gained importance in food carrying because it is harmless when being in contact with food materials. The aim of this study is to enhance the problematic adhesion properties between polyester fabrics and silicone rubber coating by plasma treatment. The fabrics are modified by air or argon RF plasmas under different power and time conditions. Influence of plasma parameters was investigated by adhesion strength tests. To investigate changes on adhesion, wettability measurements, X-ray photoelectron spectrometry (XPS), Atomic Force Microscopy (AFM), scanning electron microscopy (SEM) were performed untreated and plasma treated polyester fabrics. After plasma treatments, the coating adhesion between fabric and coating polymer was increased approximately for 4.6 times for argon and 4.3 times for air plasmas.

Keywords: adhesion; plasma; polyester; silicone; fabric.

Îmbunătățirea aderenței la interfața dintre țesătura de poliester și stratul de cauciuc siliconic, prin tratarea cu plasmă de argon și aer pentru obținerea benzilor transportoare

Realizarea benzilor transportoare necesită o bună aderență între stratul de acoperire și materialele textile. Aderența este importantă pentru proprietățile mecanice ale acestora. Cauciucul siliconic a câștigat importanță în transportul alimentelor, deoarece este inofensiv atunci când intră în contact cu produsele alimentare. Scopul acestui studiu este de a îmbunătăți proprietățile de aderență între țesăturile de poliester și stratul de cauciuc siliconic, prin tratamentul cu plasmă. Țesăturile sunt tratate cu plasme de aer sau argon RF în diferite condiții de putere și timp. Influența parametrilor tratamentului cu plasmă a fost analizată, prin teste de rezistență la aderență. Pentru a analiza modificările de aderență au fost realizate determinări ale capacităţii de umezire, spectrometrie fotoelectronică cu raze X (XPS), microscopie de forță atomică (AFM), microscopie electronică de scanare (SEM), pe țesături din poliester netratate și țesături tratate cu plasmă. După tratamentele cu plasmă, aderența dintre țesătură și polimerul de acoperire a fost crescută de aproximativ 4,6 ori pentru argon și de 4,3 ori pentru plasmele de aer.

Cuvinte-cheie: aderență, plasmă, poliester, silicon, material textil

\section{INTRODUCTION}

Conveyor belts are usually produced by one or more layers of coated fabric products. These products need high strength because they are used strained to carry materials. Polyester is the most used textile material for the production of conveyor belts. Polyester fibers have inert chemical structure and smooth surfaces so the adhesion between polyester and coating polymers is difficult to obtain [1-3]. Adhesive chemicals are used in the coating recipes to be able to overcome this difficulty. However, the chemical process is not a complete solution and in order to increase the adhesion, an adhesive is used at the interface. When coating with silicone rubber, the adhesion strength is too low to be used as a conveyor belt. Therefore, there are researches for alternative methods of enhancing adhesion [4-6].

Adhesion is sticking two different materials to each other by mutual interactions and formation of chemical bonds with a product and important to many materials; such as coating or composite structures [2,
7-10]. The cause of high strength of conveyor belts is the adhesion strength between coating polymer and fabric. The highest adhesion strength between two polymers is obtained when covalent bonds are formed. Adhesion properties are influenced by two properties of polymers (here fiber-coating polymer) simultaneously: surface energy and macromolecular mobility. There are four fundamental mechanisms that contribute to the total adhesion between two polymer materials: mechanical interlocking, interdiffusion of chains, electrical interactions and chemical interactions [3, 7-8, 11-13]. Two different solutions can be regarded to increase the adhesion between coating polymer and the fabric. The polymer side, a high molecular weight polymer having good mechanical properties can be used and for substrate side, surface roughness and surface energy can be increased by different treatments (like plasma) to enhance entanglement [13]. Surface energy gives an idea about the hydrophilic and hydrophobic nature of the material. For instance, hydrophilic materials have 
high surface energy with low contact angle and good wettability. These properties are related to adhesion strength [4, 14]. Air plasma treatments of polymer surfaces improve the adhesion strength by increasing both the surface roughness and surface energy of the material. The polar groups creation at the polymer surface and increasing the surface roughness could enchance coating layer adhesion. There are forces of physical and chemical adsorption on the polymer surface which is modified by different treatment methods to for polar groups. The formation of polar groups results in the formation of covalent bonds which are primarily responsible for adhesion [6, 13, 15-17].

Plasma technology is one of the proper methods to improve adhesion properties by changing surface properties of materials with its superficial effects up to $100 \mathrm{~A}^{\circ}$. Surface properties are changed and surface becomes suitable to adhesion by plasma processing. Additionally, plasma treatments do not harm the mechanical properties of the product like the other processes do. Plasma processing is a dry and environmentally-friendly technique, which does not call for a vast supply of water, heating or drying, and requires only little amounts of chemicals to reach the desired functionality. Investigating literature, it is seen that plasma treatment about polyester materials are focused on wettability, dyeability and yield in wet treatment [3, 12, 18-24]. Applying plasma technology, it is possible to obtain or increase the number of chemical groups at the interface that enhance binding between polymer and fiber. In addition, the adhesion surface area between polymer and fiber is increased. As a result of this, the adhesion of the fabric and the polymer was improved. Plasma treatment is used also to improve the adhesion of other polymers such as polyethylene fibers with epoxy resin [25], aramide fibers with epoxy resin [26-28]. It is seen that in order to obtain enhancement in adhesion properties, many researches are applied plasma treatments to various polyester materials e.g. polyester with rubber, polyester film with silicone film $[5,6]$, polyester fabrics with polyurethane, fluoropolymers and also for lamination [3-4, 11, 29-33].

The aim of this study is to enhance the problematic adhesion properties between polyester fabrics and silicone rubber coating. Motivation for this research was the good results of our preliminary work [34]. In order to solve the problem of adhesion, low-pressure plasma technology was used. This type of plasma has more homogenous effects than atmospheric plasmas and can penetrate deeper than atmospheric plasmas [17, 35]. Air and argon gases, different discharge powers and time in plasma processes were applied to polyester fabrics. To observe the effect of plasma treatments on surfaces, X-Ray Photoelectron Spectrometry (XPS) analysis were performed. After that plasma treated fabrics were coated by silicone rubber. Then adhesion properties of the plasma were examined by adhesion strength measurements.

\section{EXPERIMENTAL}

\section{Materials}

$300 \mathrm{~g} / \mathrm{m}^{2}$ plain weave (1:1) $100 \%$ polyester fabric was used. The settings in both warp and weft direction and linear densities of warp and weft yarns were $13 \mathrm{~cm}^{-1}, 9 \mathrm{~cm}^{-1}, \mathrm{Nm} 6$ and $\mathrm{Nm} \mathrm{11}$, respectively. Fabrics were supplied by Rultrans Transmisyon A.S. Fabrics were used as received.

\section{Plasma treatments}

Plasma polymerization treatments were carried out in PICO RF (radio frequency $13.56 \mathrm{MHz}$ ) Plasma Polymerization System (Diener electronic $\mathrm{GmbH}+$ Co. KG, Germany). After placing the fabric inside reactor was evacuated to $30 \mathrm{~Pa}$ and air and argon was allowed to flow through the reactor. Polyester fabrics were modified in air and argon gases and various plasma polymerization conditions (discharge power: 20-80 W and exposure time: 1-30 min). At the end of the process, the generator was turned off and argon gas was allowed to flow for $10 \mathrm{~min}$ to deactivate free radicals. Effects of plasma were characterized on the fabrics by X-ray photoelectron spectrometry (XPS) analysis, hydrophilicity and Scanning Electron Microscopy (SEM) analysis.

\section{Coating}

Untreated and plasma treated polyester fabrics were coated with silicone rubber. The recipe is given below:

- 90 wt\% DC M-RTV Mould Making Silicone Curing Agent (Dow Corning Corp.)

- 10 wt\% M-RTV Base Mould Making Silicone Curing Agent (Dow Corning Corp.)

Coating recipe was applied with a knife at $1 \mathrm{~mm}$ coating gap and cured for 2 minute at a curing temperature of $180^{\circ} \mathrm{C}$.

\section{Adhesion tests}

The adhesion between the silicone rubber and polyester fabrics was measured and evaluated according to TS EN ISO 252 and TS ISO 6133, respectively. For measurements Instron 4411 Universal Testing Machine was used. Six strips $25 \mathrm{~mm}$ wide and $200 \mathrm{~mm}$ long were prepared from each coated fabric sample. The peeling speed was $100 \mathrm{~mm} / \mathrm{min}$.

\section{Hydrophilicity measurements}

Hydrophilicity of treated and untreated fabrics was measured by means of capillary rise measurement. For the capillary rise test, three samples of each coated fabrics were prepared as $20 \times 2 \mathrm{~cm}^{2}$ strips parallel to the warp direction. The strips were mounted in parallel to a millimeter scale and the lower ends of the strips were partly immersed into a diluted (1 wt\%) potassium chromate aqueous solution. Height readings were made at the 10th, 30th, and 60th seconds of the first minute and at time intervals of $30 \mathrm{~s}$ in the following $4 \mathrm{~min}$. 


\section{X-Ray Photoelectron Spectroscopy (XPS)}

XPS measurements of untreated and plasma treated polyester fabrics were recorded on a PHI 5000 Versa Probe in METU Central Laboratory. This device is equipped with monochromatized aluminum X-ray source having a pass energy of $187.85 \mathrm{eV}$. Spectra were taken at $45^{\circ}$. Curve fitting of the C1s peak was done using XPSpeak 4.1 software. Because of the surface charging of non-conductive polymers (in our case polyesters), shifting of spectra occured. Shifted spectra were corrected to compensate for this effect using reference value of peak of $\mathrm{C}-\mathrm{C} / \mathrm{C}-\mathrm{H}$ bonds as $285.0 \mathrm{eV}$ [36].

\section{Scanning Electron Microscopy (SEM)}

Scanning electron microscopy (SEM) was utilized to observe and evaluate the change in surface morphology of polyester fabrics before and after plasma treatment. Samples were coated with $\mathrm{Au}-\mathrm{Pd}$ prior to imaging. SEM observations were performed by Quanta 400F Field Emission scanning electron microscope in METU Central Laboratory. Magnifications were set at 250x, 1000x and 10000x.

\section{Atomic Force Microscopy (AFM)}

The topography of the polyester fabrics was investigated by means of atomic force microscopy by Veeco Multi Mode V in METU Central Laboratory.
Measurements were carried out in tapping mode. Scan area was $5 \times 5 \mu \mathrm{m}^{2}$. Samples were measured in air.

\section{RESULTS AND DISCUSSIONS}

\section{Effects of plasma modification on adhesion strength}

Adhesion strengths of untreated and plasma treated coated fabrics were given in figures 1 and 2 . As seen in figures, low pressure plasma treatments improved adhesion between polyester fabric and silicone rubber coating.

The adhesion strength value of untreated polyester fabric is $0.16 \mathrm{~N} / \mathrm{mm}$. As can be seen from the figures, there was almost no change in adhesion strength for $20 \mathrm{~W} / 1$ min plasma treated samples for both plasma gases. This adhesion strength value was the lowest among all air and argon plasma treatments.

For air plasma treatments, at low power conditions $(20 \mathrm{~W})$, the duration of plasma treatment has almost no effect on adhesion strength (figure 1,a). However, increasing the power, the effect of air plasma time can be seen clearly. The adhesion strength at $40 \mathrm{~W} /$ $30 \mathrm{~min}$ is $104 \%$ higher than the adhesion strength at $40 \mathrm{~W} / 1 \mathrm{~min}$.

In figure $1, b$, the effect of air plasma power on adhesion strength at different plasma times can be seen.

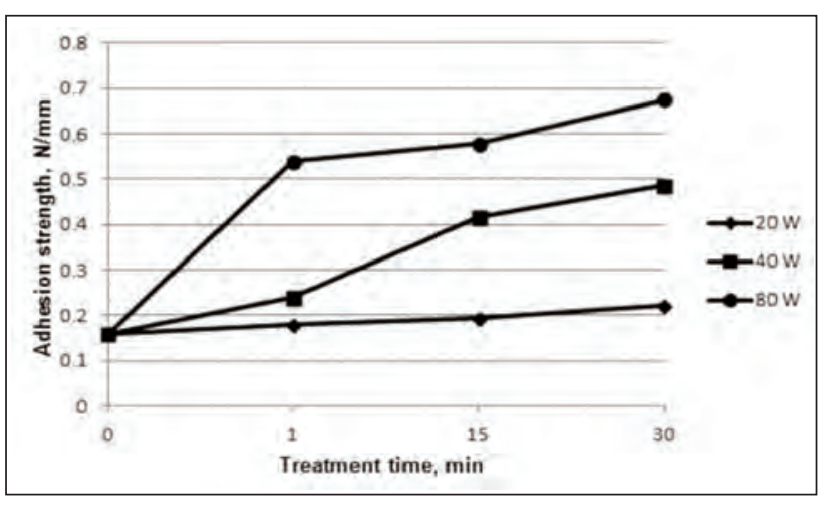

a

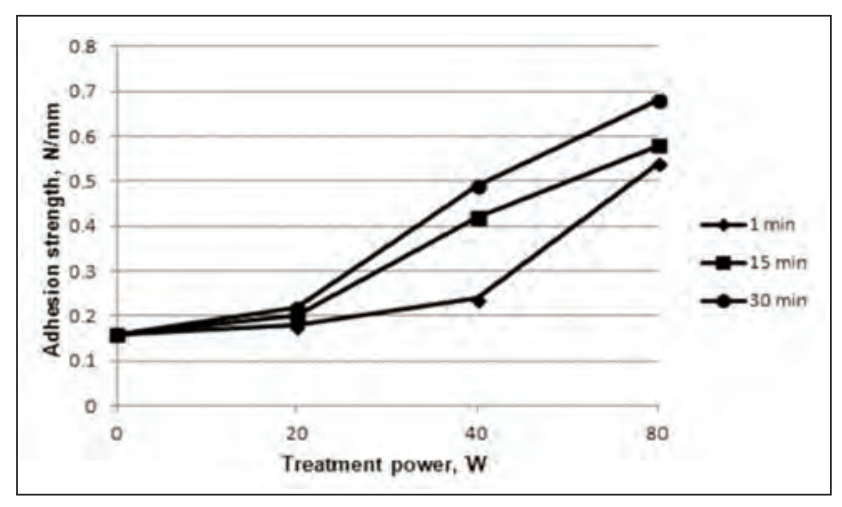

b

Fig. 1. $a$ - the effect of air plasma power on adhesion strength at different plasma treatment times, $b$ - the effect of air plasma treatment time on adhesion strength at different plasma treatment powers

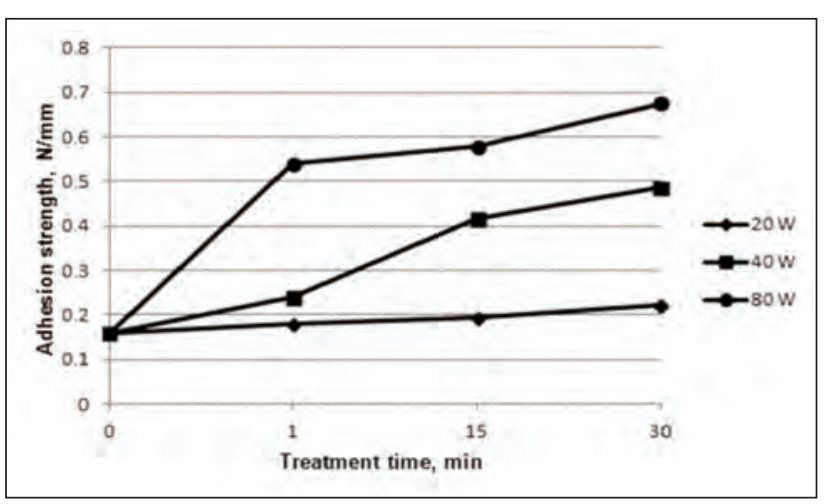

a

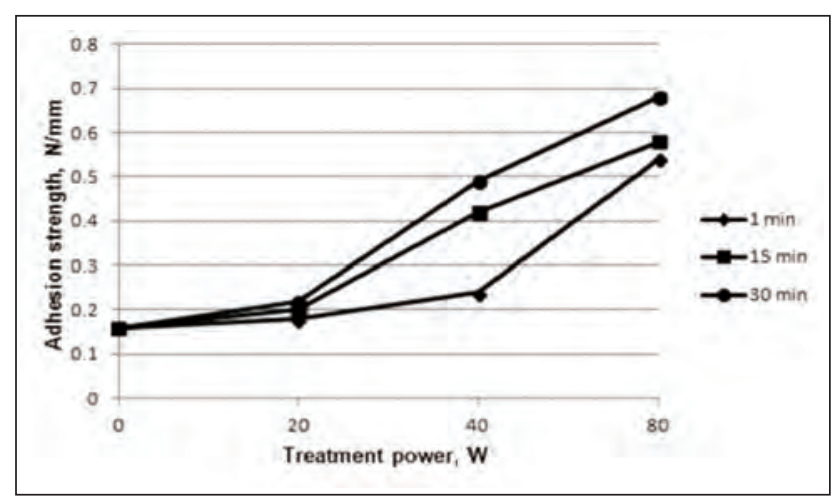

b

Fig. 2. $a$ - the effect of argon plasma power on adhesion strength at different plasma treatment times, $b$ - the effect of argon plasma treatment time on adhesion strength at different plasma treatment powers 
In this figure, the biggest change in increase in adhesion strength was obtained between $40 \mathrm{~W} / 1$ min and $40 \mathrm{~W} / 15$ min plasma conditions for air plasma. For all time conditions, the adhesion strength values at $80 \mathrm{~W}$ plasma power are approximately three times higher than the values at $20 \mathrm{~W}$ plasma power. The highest adhesion strength was obtained at the condition of $80 \mathrm{~W} / 30 \mathrm{~min}$ as $0.68 \mathrm{~N} / \mathrm{mm}$. This value is quadruple of the value of untreated fabric.

In figure 2, $a$ and $b$, the effects of argon plasma power and argon plasma time on adhesion strengths are shown. It can be seen that $20 \mathrm{~W}$ argon plasma conditions are highly effective on adhesion strength of polyester fabrics contrary to air plasma, except $20 \mathrm{~W} /$ $1 \mathrm{~min}$. For example, while the adhesion strength value after $20 \mathrm{~W} / 30 \mathrm{~min}$ air plasma was $0.22 \mathrm{~N} / \mathrm{mm}$, the adhesion strength value after $20 \mathrm{~W} / 30 \mathrm{~min}$ argon plasma was $0.37 \mathrm{~N} / \mathrm{mm}$.

Regarding the effects of argon plasma time (figure $2, a)$, the biggest difference obtained at $20 \mathrm{~W}$ from $1 \mathrm{~min}$ to $30 \mathrm{~min}$. The increase rates of adhesion strength values from $1 \mathrm{~min}$ to $30 \mathrm{~min}$ are $110 \%, 15 \%$, $21 \%$ for $20 \mathrm{~W}, 40 \mathrm{~W}, 80 \mathrm{~W}$, respectively. The highest adhesion strength was obtained at the condition of $80 \mathrm{~W} / 30 \mathrm{~min}$ as $0.73 \mathrm{~N} / \mathrm{mm}$. Regarding the effects of argon plasma power (figure 2, $b$ ), the adhesion strength at $40 \mathrm{~W} / 1 \mathrm{~min}$ is approximately three times higher than at $20 \mathrm{~W} / 1 \mathrm{~min}$.

For air and argon plasma treatments, increasing plasma power and time caused an increase in adhesion strength and the highest coating adhesion value was obtained at $80 \mathrm{~W} / 30 \mathrm{~min}$ plasma condition. However, it can be seen from the results that power is more effective than time as plasma condition. In addition, according to the results, argon plasma treatments are found to be more effective than air plasma treatments.

\section{Hydrophilicity of fabrics}

The effects of discharge power and exposure time parameters on the hydrophilicity of untreated and plasma treated polyester fabrics were evaluated and presented graphically in figures 3 and 4 .

All plasma treatments seem to enhance the hydrophilic character of polyester fabrics. Even at initial rises at $10 \mathrm{~s}$, this effect can be seen for all

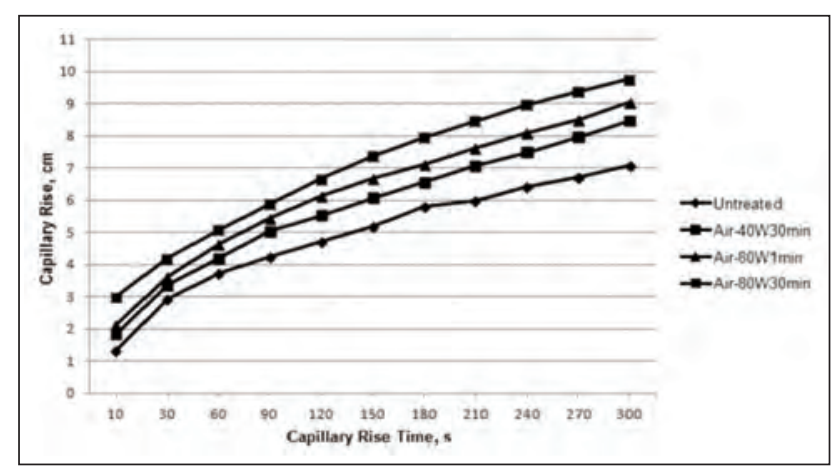

a plasma conditions. This capillary values are $1.3 \mathrm{~cm}$, $1.8 \mathrm{~cm}, 2.1 \mathrm{~cm}, 3.0 \mathrm{~cm}, 1.9 \mathrm{~cm}, 2.3 \mathrm{~cm}, 3.2 \mathrm{~cm}$ for untreated and $40 \mathrm{~W} / 30 \mathrm{~min}$ air, $80 \mathrm{~W} / 1 \mathrm{~min}$ air, $80 \mathrm{~W} /$ $30 \mathrm{~min}$ air, $40 \mathrm{~W} / 30 \mathrm{~min}$ argon, $80 \mathrm{~W} / 1 \mathrm{~min}$ argon and $80 \mathrm{~W} / 30 \mathrm{~min}$ argon plasma treated fabrics, respectively (figure $3, a$ ).

As can be seen from the figures and the values, argon plasma treatments enhance hydrophilicity more than air plasma treatments. As stated in literature, increase in wettability is caused by argon plasma due to surface oxidation. Even argon plasma has no oxygen atoms, oxidation reactions occur at the carbon radicals after finishing plasma discharge [37]. The capillary rise value at $300 \mathrm{~s}$ for air and argon plasma at $80 \mathrm{~W} / 30 \mathrm{~min}$ is $15 \%, 20 \%$ higher than the rise at $40 \mathrm{~W} / 30 \mathrm{~min}$, respectively. Additionally, the capillary rise values at $300 \mathrm{~s}$ for air and argon plasma at $80 \mathrm{~W} / 30 \mathrm{~min}$ were $8 \%$ and $11 \%$ higher than the values at $80 \mathrm{~W} / 1 \mathrm{~min}$, respectively. These results show that the RF plasma power is more effective than RF plasma duration time. Furthermore, these results support the results of adhesion strength measurements (figure $3, b)$.

\section{XPS measurement}

In order to detect the effects of plasma treatments on the chemical composition of the surfaces, XPS analysis was applied. XPS spectra of untreated, air plasma and argon plasma treated polyester fabrics are shown in figure 4 . In this XPS wide survey spectra, the main photoelectrons of carbon, oxygen and nitrogen can be seen.

All survey spectra show photoelectron peaks at binding energies of $\sim 532 \mathrm{eV}, \sim 400 \mathrm{eV}, \sim 285 \mathrm{eV}$, and $\sim 164 \mathrm{eV}$, which can be attributed to the 01s, N1s, C1s, and S2p, respectively [20]. Additionally, Si2p peak is observed (at $\sim 102 \mathrm{eV}$ ) in one spectrum as seen in table 1 . The reason for this can be the contamination from the silicone coating paste. Atomic percentages of carbon, oxygen, nitrogen and the other atoms found in the surface of untreated and treated polyester fabrics are given in table 1.

The atomic concentrations of carbon and oxygen of the untreated polyester fabric was $84.4 \%$ and $15.6 \%$, respectively. The best adhesion obtained at $80 \mathrm{~W} /$ $30 \mathrm{~min}$ in argon plasma. For that fabric sample, the atomic concentration of carbon was decreased

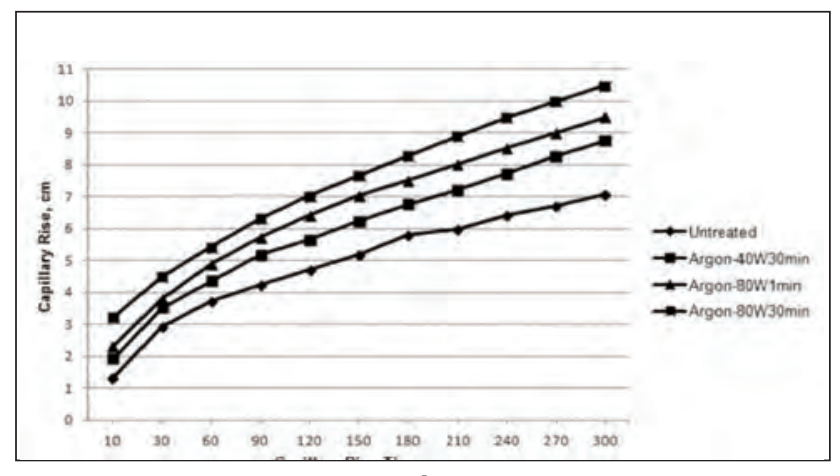

b

Fig. 3. The effect of: $a-$ air and $b$ - argon plasma treatments on capillary rise $(\mathrm{cm})$ of polyester fabrics 


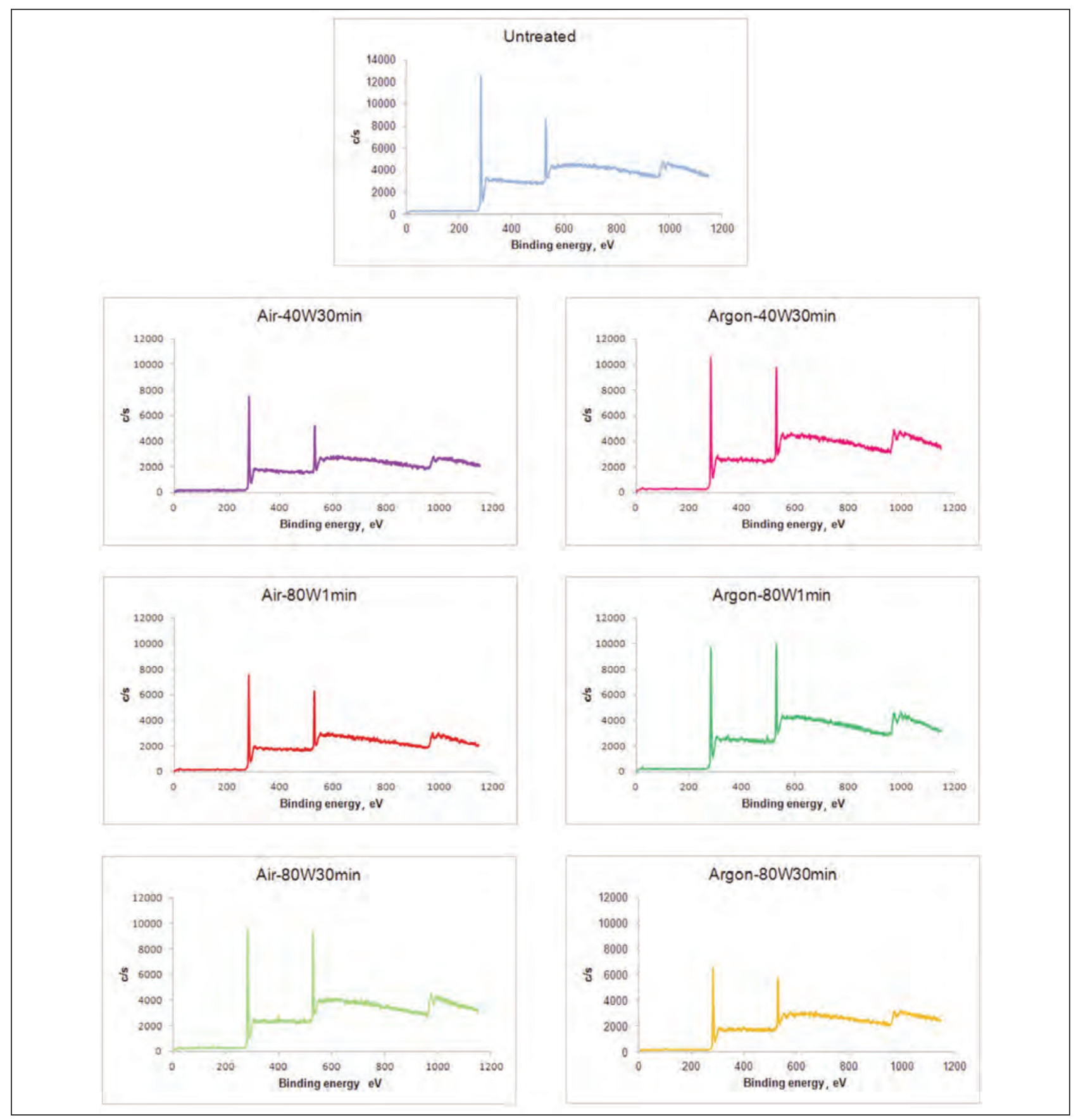

Fig. 4. XPS results of untreated and treated polyester fabrics

Table 1

CHEMICAL COMPOSITIONS AND O/C ATOMIC RATIOS FOR UNTREATED AND PLASMA TREATED POLYESTER SURFACES

\begin{tabular}{|c|c|c|c|c|c|c|}
\hline \multirow{2}{*}{ Fabrics } & \multicolumn{5}{|c|}{ Surface chemical composition (\%) } & \multirow{2}{*}{\begin{tabular}{|c} 
Atomic \\
ratio \\
O/C \\
\end{tabular}} \\
\hline & C & 0 & $\mathbf{N}$ & $\mathbf{S}$ & Si & \\
\hline Untreated & 84.4 & 15.6 & - & - & - & 0.19 \\
\hline Air-40 W/30 min & 81.9 & 18.1 & - & - & - & 0.22 \\
\hline Argon-40 W/30 min & 77.1 & 22.3 & 0.7 & - & - & 0.29 \\
\hline Air-80 W/1 min & 79.8 & 20.2 & - & - & - & 0.25 \\
\hline Argon-80 W/1 min & 77.1 & 22.2 & 0.7 & - & - & 0.29 \\
\hline Air-80 W/30 min & 73.9 & 22.7 & 2.0 & 0.2 & 1.1 & 0.31 \\
\hline Argon-80 W/30 min & 75.1 & 23.7 & 1.2 & - & - & 0.32 \\
\hline
\end{tabular}

(75.1\%). Contrary to carbon, oxygen showed an increase in a concentration as $23.7 \%$. Incorporated oxygen atoms after plasma treatments were increased by time and power conditions. Argon plasma is known to lead to cross-linking in combination with surface oxidation. If cross-linking is dominant, it inhibits surface oxidation resulting in lower oxygen functionalities [38-40]. However, in this research, oxygen functionalities increased after treatments which shows that cross-linking has not dominate yet in these conditions. As seen in table 1, O/C atomic ratios were increased for all plasma treated samples compared to untreated one (0.19). For $80 \mathrm{~W} /$ 30 min air and argon plasma treated samples, 
$\mathrm{O} / \mathrm{C}$ ratios were found as $0.31,0.32$, respectively. Regarding these increased ratios, it can be concluded that oxygen-containing functional groups are formed on the polyester fabric surface after air or argon plasma and these may be the reason of increase hydrophilicity [5, 40-41]. Additionally, very small amounts of nitrogen and sulphur were found on polyester surfaces after all argon plasma treatments and $80 \mathrm{~W} / 30 \mathrm{~min}$ air plasma treatment. This may confirm the deposition of reactive species on plasma treated active surfaces [42].

Peak fitting of C1s peaks of XPS spectra for untreated and plasma treated fabrics were realized to get detailed information about the altered species on the polyester surfaces. C1s high resolution spectra were fitted to investigate the functional groups formed after air and argon plasma treatments (figure 5). Percentage ratios of plotted areas of peaks are given in table 2 .
C1s core level spectrum of untreated polyester fabric is shown in figure $5, a$. The peaks of $\mathrm{C} 1 \mathrm{~s}$ spectrum for untreated polyester at $285.0 \mathrm{eV}, 286.4 \mathrm{eV}$ and 289.0

Table 2

RESULTS OF DECONVOLUTION OF C1s PEAKS

\begin{tabular}{|c|c|c|c|c|}
\hline \multirow[b]{2}{*}{ Fabrics } & \multicolumn{4}{|c|}{ Ratios of C1s components (\%) } \\
\hline & \begin{tabular}{|c|}
$-C-C-$ \\
$285.0 \mathrm{eV}$
\end{tabular} & $\begin{array}{c}-\mathrm{C}-\mathrm{O}- \\
286.4 \mathrm{eV}\end{array}$ & $\begin{array}{c}\mathrm{O}=\mathrm{C}-\mathrm{O} \\
289.0\end{array}$ & $\begin{array}{c}-\mathrm{C}=\mathrm{O} \\
288.0 \mathrm{eV}\end{array}$ \\
\hline Untreated & 65.21 & 29.03 & 5.76 & - \\
\hline Air-40 W/30 min & 64.71 & 28.36 & 6.93 & - \\
\hline Argon-40 W/30 min & 64.12 & 25.81 & 10.07 & - \\
\hline Air-80W/1 min & 63.47 & 29.78 & 6.75 & - \\
\hline Argon-80 W/1 min & 61.71 & 28.08 & 9.62 & 0.58 \\
\hline Air-80 W/30 min & 61.36 & 29.33 & 9.31 & - \\
\hline Argon- $80 \mathrm{~W} / 30 \mathrm{~min}$ & 47.73 & 33.81 & 13.47 & 4.99 \\
\hline
\end{tabular}

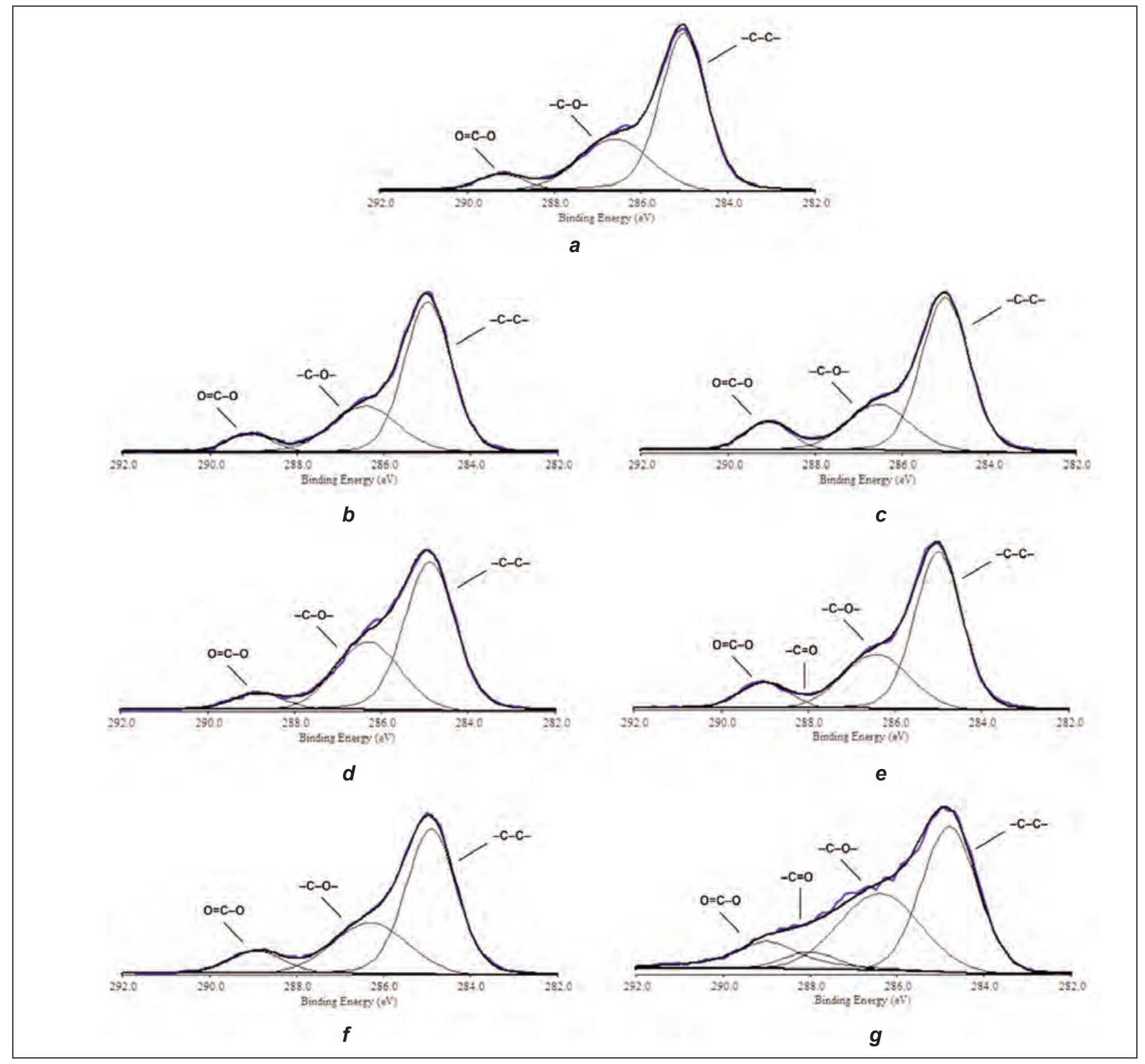

Fig. 5. C1s spectra of polyester fabrics: $a-$ untreated, $b-$ air- $40 \mathrm{~W} / 30 \mathrm{~min}, c-\operatorname{argon}-40 \mathrm{~W} / 30 \mathrm{~min}, d-\operatorname{air}-80 \mathrm{~W} / 1 \mathrm{~min}$, $e-\operatorname{argon}-80 \mathrm{~W} / 1 \mathrm{~min}, f-$ air-80 W/30 $\mathrm{min}, g-\operatorname{argon}-80 \mathrm{~W} / 30 \mathrm{~min}$ 
eV may be identified as $-\mathrm{C}-\mathrm{C}-,-\mathrm{C}-\mathrm{O}-$ and $\mathrm{O}=\mathrm{C}-\mathrm{O}$, respectively [38, 42-44]. The plasma treatments, as shown in figure $5, b, c, d, e, f, g$, led to obvious changes in the C1s spectra. In $80 \mathrm{~W} / 1 \mathrm{~min}$ and $80 \mathrm{~W} / 30 \mathrm{~min}$ argon plasma conditions, a new peak at $288.0 \mathrm{eV}$ was detected and it may be attributed to $-\mathrm{C}=\mathrm{O}$ bond. As seen from the figure 5, oxidation on the surfaces was significant by the increase in the intensities of the $-\mathrm{C}-\mathrm{O}-$ and $\mathrm{O}=\mathrm{C}-\mathrm{O}$ peaks compared to the intensities of the $-\mathrm{C}-\mathrm{C}-$ peak [43]. These results indicate that some of the $-\mathrm{C}-\mathrm{C}-$ bonds in polymer surface may be broken by the bombardment by the active species in plasma medium. Increase in the hydrophilicity of polyester fabrics may be due to the increase in the polar groups [42]. The highest alteration in $\mathrm{C} 1 \mathrm{~s}$ peaks was obtained from $80 \mathrm{~W} / 30 \mathrm{~min}$ argon plasma treated polyester fabric. These alterations are observed as decrease in $-\mathrm{C}-\mathrm{C}-$ peak and increases in peaks of oxygen containing groups on the polyester surface. Besides, radicals are produced on the polymer surface by plasma treatments via polymer chain scission or hydrogen abstraction. Possible combination of these radical species with atmospheric gas atoms, contribute the increase in the amount of polar groups on the treated polymer surfaces [44]. This combination can be the reason for nitrogen and sulphur atoms were detected in XPS wide survey spectra.

\section{SEM}

SEM image of untreated fabric is given in figure 6 . As seen in figure 6 and as known, surface of polyester fibers is quite smooth. However, in this figure small particles are seen on the surface. To identify which elements are present in these particles, SEM-EDX (energy dispersive X-ray microanalysis) was conducted. Figure $7, a$ and $b$ shows SEM image of a particle and its EDX spectrum, respectively. The particle was identified as $\mathrm{NaCl}$ crystal. The reason for having these particles on the fiber surfaces can be the insufficient removal of fiber/fabric production chemicals.

SEM images of plasma treated fabrics are presented in figure 8.

In figures 6 and 8 , it is seen that there has not been a lot of changes in the fiber morphology. Only change is the increase in the amount of particles on the fabric surface, parallel to the increase in plasma power and time. Figure $8, e$ and $f$ shows the SEM images of the polyester fabrics after air-80 W/30 min and argon$80 \mathrm{~W} / 30$ min plasma treatments, respectively. Especially in extended plasma treatments, accumulation can be seen on the polyester fiber surfaces. SEM-EDX analysis was conducted to investigate this accumulation for $80 \mathrm{~W} / 30 \mathrm{~min}$ air plasma treated fabric (figure 9, a, b). Results of his SEM-EDX showed that this deposited matter was composed of mostly $\mathrm{C}$ and $\mathrm{O}$ atoms. Therefore, we can conclude that these particles were

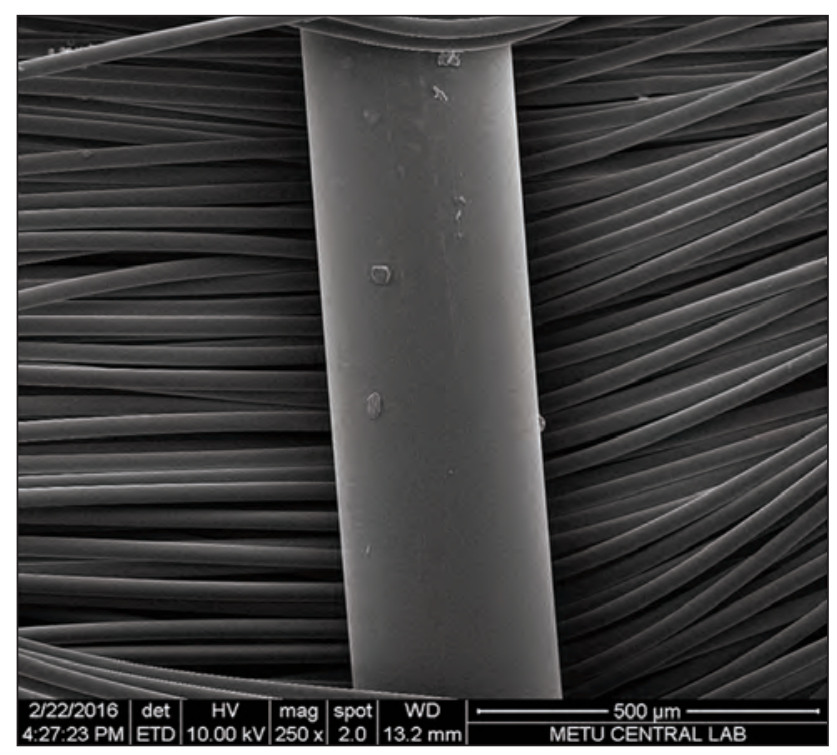

Fig. 6. SEM image of untreated polyester fabric

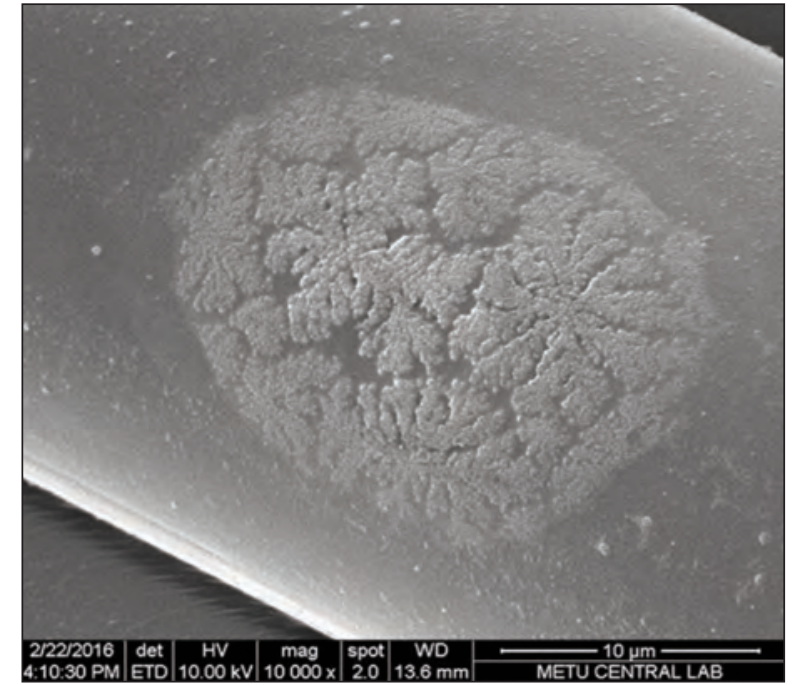

a

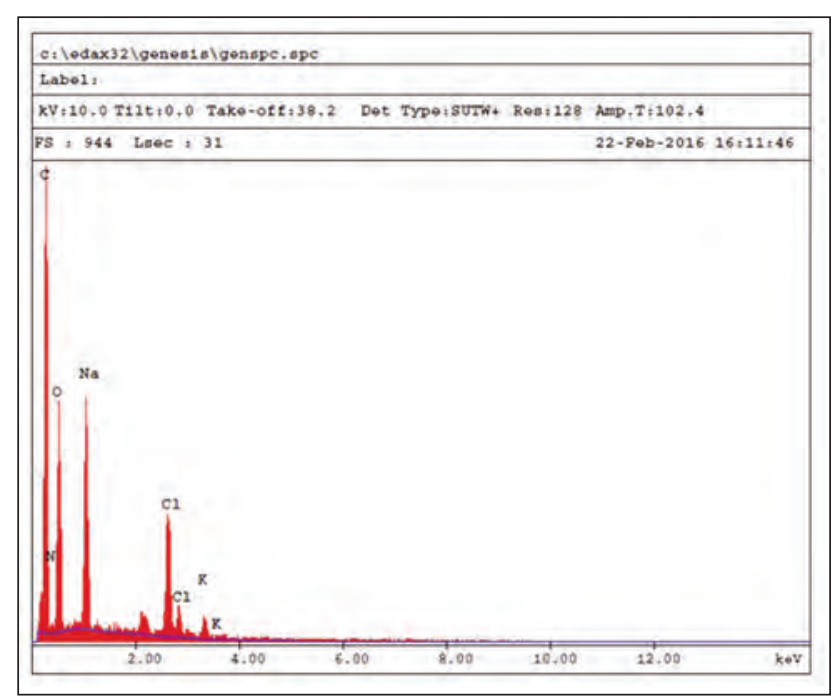

b

Fig. 7. $a$ - SEM image of argon- $80 \mathrm{~W} / 1$ min plasma treatment, $b$ - EDX analysis of argon- $80 \mathrm{~W} / 1$ min plasma treatment 


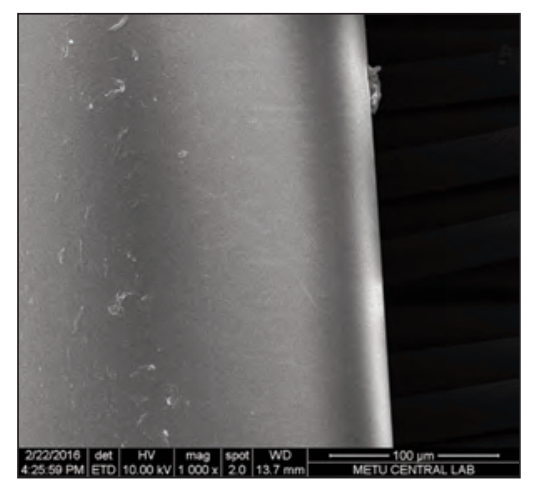

a

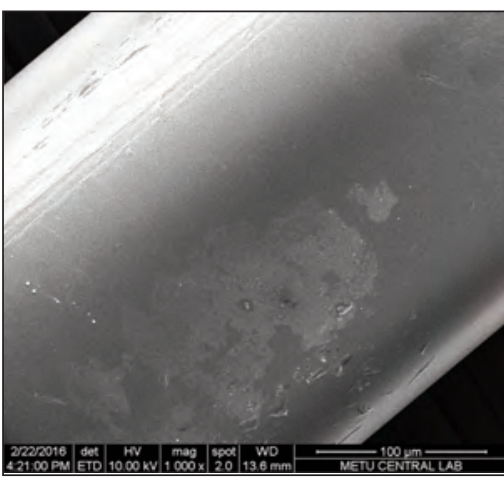

c

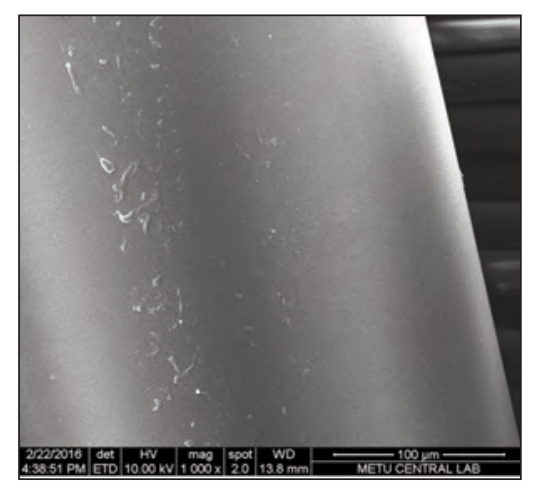

e

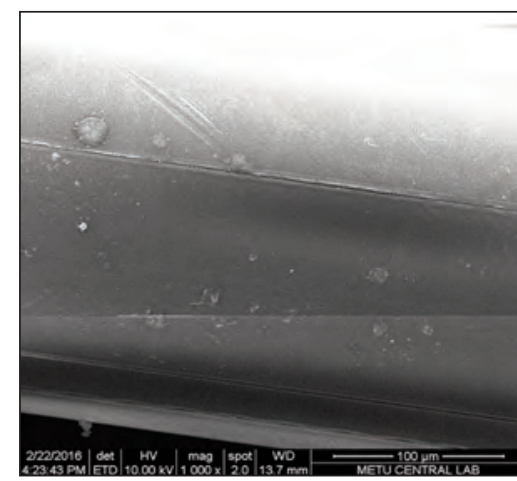

b

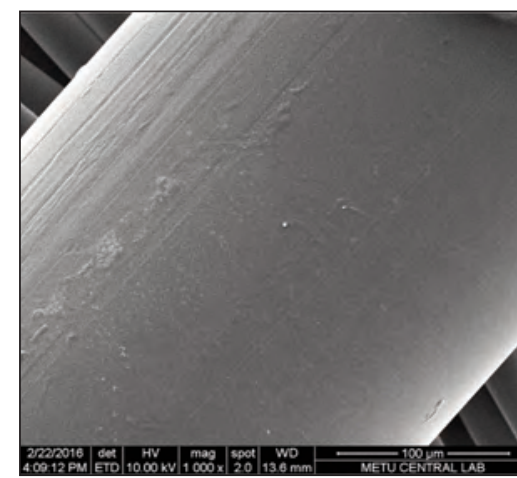

d

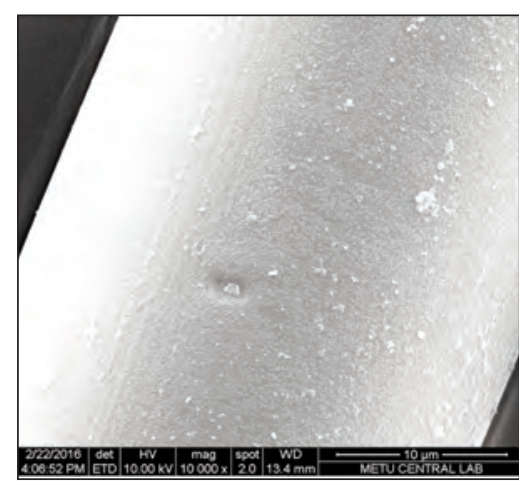

$f$
Fig. 8. SEM images of plasma treated polyester fabrics: $a-$ air-40 W/30 min, $b$ - argon-40 W/30 min, $c$ - air- $80 \mathrm{~W} / 1 \mathrm{~min}$, $d-\operatorname{argon}-80 \mathrm{~W} / 1 \mathrm{~min}, e-$ air-80 W/30 min, $f-\operatorname{argon}-80 \mathrm{~W} / 30 \mathrm{~min}$ coming from polyester fibers, which were destroyed and deposited on the fiber surfaces because of the collisions occurred in the discharge medium [40].

As can be seen from the figures, SEM images did not indicate significant difference between untreated and plasma treated polyester fabrics. Because, scanning electron microscopy has limited depth resolution, morphological changes below micrometer size are difficult to detect. For this reason, atomic force microscopy was applied to obtain more detailed morphological information about the fiber surfaces $[44,45]$.

\section{AFM}

To investigate topography of the polyester fabric surfaces, AFM images (figure 10) were taken from untreated and plasma treated polyester fabrics. In addition, surface roughness data was collected from samples. The root mean square roughness $\left(R_{q}\right)$ values are seen in table 3 .

Untreated polyester fabric had smooth and uniform surface. However, the surfaces became rough after air and argon plasma treatments [43]. This suggested that effects of air and argon plasmas showed effective etching processes. Argon plasma caused more roughness than air plasma. Poletti et al. explained the reason for this, as the difference between average

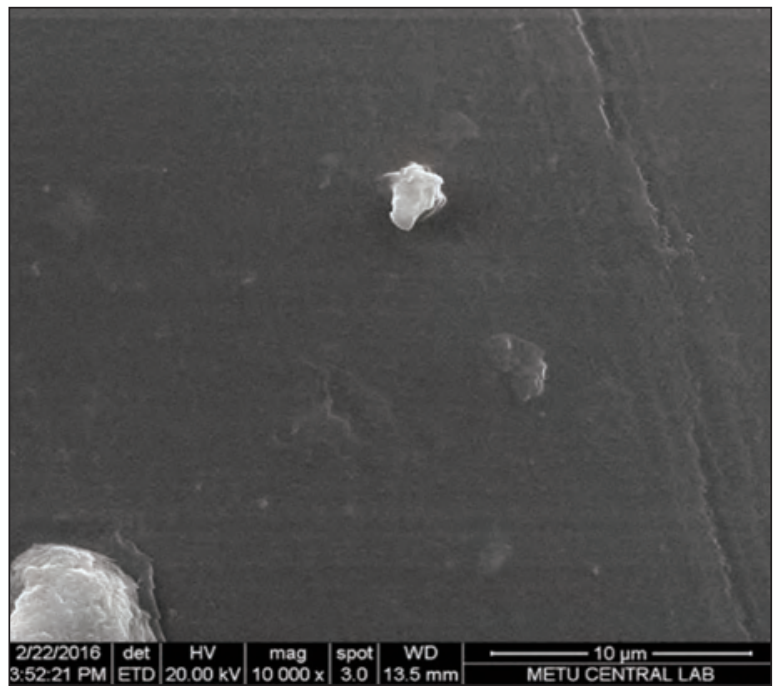

a

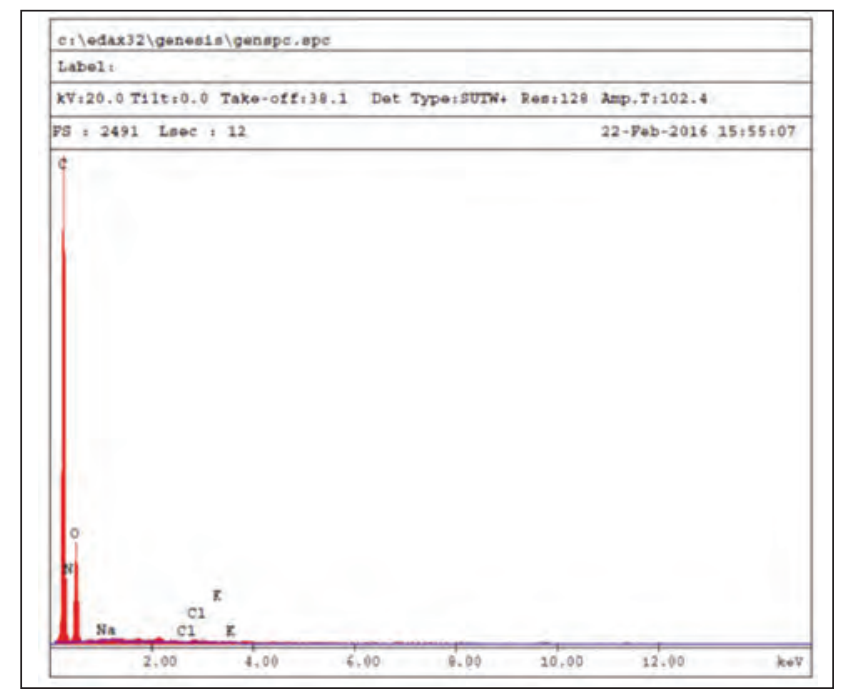

b

Fig. 9. $a$ - SEM image of air-80 W/30 min plasma treatment, $b-$ EDX analysis of air- $80 \mathrm{~W} / 30 \mathrm{~min}$ plasma treatment 


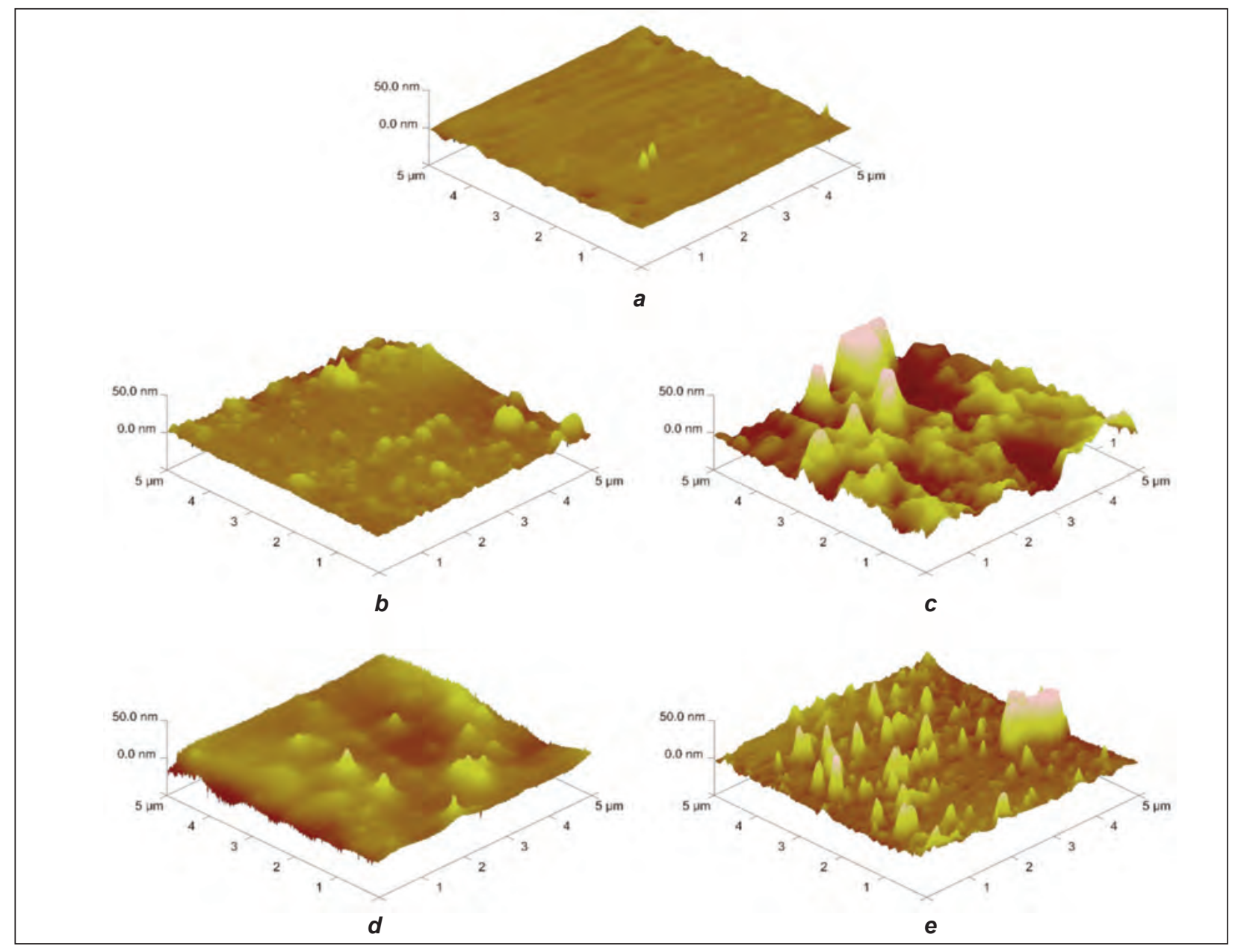

Fig. 10. AFM images of untreated and plasma treated polyester surfaces: $a-$ untreated, $b-$ air- $80 \mathrm{~W} / 1 \mathrm{~min}$, $c-$ argon-80 W/1 min, $d-$ air-80 W/30 min, e - argon-80 W/30 min

\section{Table 3}

THE ROOT MEAN SQUARE ROUGHNESS $\left(R_{q}\right)$ VALUES OF UNTREATED AND PLASMA TREATED POLYESTER FABRICS

\begin{tabular}{|c|c|}
\hline Fabrics & $\mathbf{R}_{\mathbf{q}}(\mathbf{n m})$ \\
\hline Untreated & 1.39 \\
\hline Air-80 W/1 min & 3.86 \\
\hline Argon-80 W/1 min & 9.45 \\
\hline Air-80 W/30 min & 5.23 \\
\hline Argon-80 W/30 min & 9.71 \\
\hline
\end{tabular}

dimensions of the bombarding ions, i.e. argon ions are bigger than the ions in air. This could be also attributed the significant etching effect of the noble gases [45]. In addition, increase in air and argon plasma times increased the surface roughness of polyester fabrics. These results are convenient with literature. As can be seen from the results of AFM and XPS analyses, the increase in hydrophilicity can be attributed to both the roughened surface and the incorporation of polar atoms [39, 42-43, 45]. The results of AFM analysis also confirmed that argon plasma is superior to air plasma for improvement of adhesion.

\section{CONCLUSION}

In this article, at various plasma conditions (different plasma powers and plasma times) of polyester fabrics with air and argon gases are modified, these fabrics coated by silicone rubber and then adhesion strengths were measured. It was showed that plasma pretreatments have led to an increase in adhesion strength of problematic coating between the polyester fabric and silicone rubber coating by both air and argon plasmas. Comparing influences of the plasma parameters, plasma power was found to be superior to plasma time. Capillary rise measurements confirmed these findings. Oxygen containing functional groups are increased by increasing power and time of plasma treatments. The best adhesion strength obtained at $80 \mathrm{~W} / 30$ min treatment condition in argon plasma. All plasma treatments increased the wettability and adhesion strength. However, the roughness of the polyester fabrics was increased by the increase in plasma treatment time. As indicated by the analyses and test performed, the adhesion strength was enhanced mainly due to an increased surface roughness and presence of oxygen containing groups on the plasma treated polyester surface. 


\section{ACKNOWLED GEMENTS}

The authors would like to thank to Rultrans Transmisyon A.Ş., Izmir-Turkey for supplying fabrics and chemicals for the research and allowing using their coating apparatus.
This research did not receive any specific grant from funding agencies in the public, commercial, or not-for-profit sectors.

This work was presented in TextehVIII in 2017.

\section{REFERENCES}

[1] Fung, W., Hardcastle, M., Textiles in automotive engineering, first ed., Woodhead Publishing Limited, Cambridge, 2001

[2] Sen, A.K., Coated textiles principles and applications, second ed., Taylor and Francis Group, Boca Raton, 2008.

[3] Šimor, M., Creyghton, Y., Wypkema, A., Zemek J., The influence of surface DBD plasma treatment on the adhesion of coatings to high-tech textiles, In: J. Adhesion Sci. Technol., 2010, 24, 77-97

[4] Krump, H., Šimor, M., Hudec, I., Jaššo, M., Luyt, A.S., Adhesion strength study between plasma treated polyester fibres and a rubber matrix, In: Appl. Surf. Sci., 2005, 240, 268-274

[5] Rusu, I.A., Popa, G., Saied, S.O., Sullivan, J.L., Argon rf plasma treatment of PET films for silicon films adhesion improvement, In: J. Optoelectron. Adv. Mater., 2005, 7, 5, 2529-2534

[6] Leroux, F., Campagne, C., Perwuelz, A., Gengembre, L., Atmospheric air plasma treatment of polyester textile materials. Textile structure influence on surface oxidation and silicon resin adhesion, In: Surf. Coat. Technol., 2009, 203, 3178-3183

[7] Björkman, M., Improved adhesion of polyolefin laminates to textiles using new plasma technology, MSc. Thesis. http://publications.lib.chalmers.se/records/fulltext/161579.pdf, 2016, (accessed 14.07.16)

[8] Ebnesajjad, S., Ebnesajjad, C.F., Surface treatment of materials for adhesion bonding, second ed., William Andrew Inc., Waltham, 2014

[9] Fung, W., Coated and laminated textiles, first ed., Woodhead Publishing Limited, Cambridge, 2002

[10] Morent, R., De Geyter, N., Verschuren, J., De Clerck, K., Kiekens, P., Leys, C., Non-thermal plasma treatment of textiles, In: Surf. Coat. Technol., 2008, 202, 3427-3449

[11] Carlotti, S., Mas, A., Improvement of adhesion of PET fibers to rubber by argon-oxygen plasma treatment, In: J. Appl. Polym. Sci., 1998, 69, 2321-2330

[12] Lima da Silva, R.C., Alves Jr, C., Nascimento, J.H., Neves, J.R.O., Teixeira, V., Surface modification of polyester fabric by non-thermal plasma treatment, In: J. Phys. Conference Series, 2012, 406, 1-10

[13] Molina, R., Esquena, J., Erra, P., Interfacial processes in textile materials: Relevance to adhesion, In: J. Adhesion Sci. Technol., 2010, 24, 7-33

[14] Romdhani, Z., Baffoun, A., Hamdaoui, M., Roudesli , S., General behavior and parameters affecting the ink jet printing phenomenon on woven polyester fabric, In: Industria Textila, 2017, 68, 1, 37-46, https://doi.org/10.35530/ IT.068.01.1327

[15] Bhatnagar, N., Jha, S., Bhowmik, S., Gupta, G., Moon, J.B., Kim, C.G., Physico-chemical characteristics of high performance polymer modified by low and atmospheric pressure plasma, In: Surf. Eng. Appl. Electrochem., 2012, $48,2,117-126$

[16] Krump, H., Hudec, I., Jaššo, M., Dayss, E., Luyt, A.S., Physical-morphological and chemical changes leading to an increase in adhesion between plasma treated polyester fibres and a rubber matrix, In: Appl. Surf. Sci., 2006, 252, 4264-4278

[17] Rauscher, H., Perucca, M., Buyle, G., Plasma systems for surface treatment, In: Plasma Technology for Hyperfunctional Surfaces Food, Biomedical and Textile Applications, WILEY-VCH Verlag GmbH \& Co. KGaA, Weinheim, 2010, 33-62

[18] Cireli, A., Kutlu, B., Mutlu, M., Surface modification of polyester and polyamide fabrics by low frequency plasma polymerization of acrylic acid, In: J. Appl. Polym. Sci., 2007, 104, 2318-2322

[19] Costa, T.H.C., Feitor, M.C., Alves Jr, C., Freire, P.B., De Bezerra, C.M., Effects of gas composition during plasma modification of polyester fabrics, In: J. Mater. Process. Technol., 2006, 173, 40-43

[20] Kutlu, B., Aksit, A., Mutlu, M., Surface modification of textiles by glow discharge technique: Part II: Low frequency plasma treatment of wool fabrics with acrylic acid, In: J. Appl. Polym. Sci., 2010, 116, 1545-1551

[21] Lieberman, M.A., Lichtenberg, A.J., Principles of plasma discharges and materials processing, second ed., John Wiley\&Sons, Inc., New Jersey, 2005

[22] Raslan, W.M., Rashed, U.S., El-Sayad, H., El-Halwagy, A.A., Ultraviolet protection, flame retardancy and antibacterial properties of treated polyester fabric using plasma-nano technology, In: Mater. Sci. Appl., 2011, 2, 1432-1442

[23] Sharnina, L.V., Low temperature plasma as the basis for creation of modern textile chemical technologies, In: Fibre Chem., 2004, 36, 6, 431-436

[24] Shishoo, R., Plasma technologies for textiles, first ed., Woodhead Publishing Limited, Cambridge, 2007

[25] Huang, C.Y., Wu, J.Y., Tsai, C.S., Hsieh, K.H., Yeh, K.N., Effects of argon plasma treatment on the adhesion property of ultra high molecular weight polyethylene (UHMWPE) textile, In: Surf. Coat. Technol., 2013, 231, 507-511 
[26] Gu, R., Yu, J., Hu, C., Chen, L., Zhu, J., Hu, Z., Surface treatment of para-aramid fiber by argon dielectric barrier discharge plasma at atmospheric pressure, In: Appl. Surf. Sci., 2012, 258, 10168-10174

[27] Hwang, Y.G., Characterization of atmospheric pressure interactions with textile/polymer substrates, Ph.D. Thesis, http://repository.lib.ncsu.edu/ir/bitstream/1840.16/4538/1/etd.pdf, 2016, (accessed 14.07.16)

[28] Jia, C., Chen, P., Liu, W., Li, B., Wang, Q., Surface treatment of aramid fiber by air dielectric barrier discharge plasma at atmospheric pressure, In: Appl. Surf. Sci., 2011, 257, 4165-4170

[29] Janca, J., Stahel, P., Buchta, J., Subedi, D., Krcma, F., Pryckova, J., A plasma surface treatment of polyester textile fabrics used for reinforcement of car tires, In: Plasmas Polym., 2001, 6, 1/2, 15-26

[30] Wennekes, W.B., Adhesion of RFL-treated cords to rubber: new insights into interfacial phenomena, Ph.D. Thesis. http://doc.utwente.nl/58363/1/thesis_Wennekes.pdf, 2016, (accessed 14.07.16)

[31] Alam, R., Hossain, G., Grabher, G., Hossain, M., Applications of low pressure plasma in high-tech textiles, In: $13^{\text {th }}$ International Conference on Plasma Surface Engineering, http://www.ep.liu.se/wcc/002/065/wcc12002065.pdf, 2016, (accessed 14.07.16)

[32] Leroux, F., Campagne, C., Perwuelz, A., Gengembre, L., Fluorocarbon nano-coating of polyester fabrics by atmospheric air plasma with aerosol, In: Appl. Surf. Sci., 2008, 254, 3902-3908

[33] Armagan, O.G., Karaguzel, Kayaoglu, B., Canbaz, Karakas, H., Guner, F.S., Improving the adhesion strength of polypropylene nonwoven laminated fabrics using low-pressure plasma, In: Fibres Text. East. Eur., 2013, 21, 3, 99, 96-101

[34] Sari, Y.B., Kutlu, B., Mizrak, B., Effects of plasma treatments on the adhesion between polyester fabrics and silicone rubber coating, http://ieeexplore.ieee.org/document/7179525/?arnumber=7179525\&tag=1, ICOPS 2015, (accessed 14.07.16)

[35] Poll, H.U., Schladitz, U., Schreiter, S., Penetration of plasma effects into textile structures, In: Surf. Coat. Technol., 2001, 142-144, 489-493

[36] Vandencastelee, N., Reniers, F., Plasma-modified polymer surfaces: characterization using XPS, In: J. Electron. Spectrosc. Relat. Phenom., 2010, 178-179, 394-408

[37] Inagaki, I., Tasaka, S., Narushima, K., Kobayashi, H., Surface modification of PET films by pulsed argon plasma, In: J. Appl. Polym. Sci., 2002, 85, 2845-2852

[38] Geyter, N.D., Morent, R., Leys, C., Gengembre, L., Payen, E., Treatment of polymer films with a dielectric barrier discharge in air, helium and argon at medium pressure, In: Surf. Coat. Technol., 2007, 201, 7066-7075

[39] Liu, D., Chen, P., Chen, M., Yu, Q., Lu, C., Effects of argon plasma treatment on the interfacial adhesion of PBO fiber/bismaleimide composite and aging behaviors, In: Appl. Surf. Sci., 2011, 257, 10239-10245

[40] Morent, R., Geyter, N.D., Leys, C., Gengembre, L., Payen, E., Surface modification of non-woven textiles using a dielectric barrier discharge operating in air, helium and argon at medium pressure, In: Textile Res. J., 2007, 77, 7, 471-488

[41] Borcia, G., Anderson, C.A., Brown, N.M.D., Surface treatment of natural and synthetic textiles using a dielectric barrier discharge, In: Surf. Coat. Technol., 2006, 201, 3074-3081

[42] Pandiyaraj, K.N., Selvarajan, V., Deshmukh, R.R., Bousmina, M., The effect of glow discharge plasma on the surface properties of Poly (ethylene terephthalate) (PET) film, In: Surf. Coat. Technol., 2008, 202, 4218-4226

[43] Gupta, H., Hilborn, J., Hollenstein, C., Plummer, C.J.G., Houriet, R., Xanthopoulos, N., Surface modification of polyester films by RF plasma, In: J. Appl. Polym. Sci., 2000, 78, 1083-1091

[44] Riccardi, C., Barni, R., Selli, E., Mazzone, G., Massafra, M.R., Marcandalli, B., Poletti, G., Surface modification of poly(ethylene terephthalate) fibers induced by radio frequency air plasma treatment, In: Appl. Surf. Sci., 2003, 211, 386-397

[45] Poletti, G., Orsini, F., Raffaele-Addamo, A., Riccardi, C., Selli, E., Cold plasma treatment of PET fabrics: AFM surface morphology characterisation, In: Appl. Surf. Sci., 2003, 219, 311-316

Authors:

\section{Y. BERRAK SARI, BENGI KUTLU}

Dokuz Eylul University, Faculty of Engineering,

Textile Engineering Department, 35397, Izmir, Turkey

Corresponding author:

BENGI KUTLU

e-mail: bengi.kutlu@deu.edu.tr 


\title{
Increasing effectiveness of the sewing methods for products with special destination
}

\author{
DOI: $10.35530 / I T .070 .05 .1518$
}

\section{ABSTRACT - REZUMAT}

\section{Increasing effectiveness of the sewing methods for products with special destination}

The execution of the products with special destination requires solving two problems: assuring a high degree of protection of the consumer, acquired by structural and technological design, according with the product destination and increasing the operator's responsibility for the quantitative and qualitative result of the work, by implementing rigorous work methods for the sewing operations. The final result will be economical efficiency of the companies. Paper's aim is to analyze different solutions for the sewing operations for military equipment (for example, products designed to carry grenades or radio stations). The case study was made in a clothing company, with the particularity that, for increasing work responsibility, one operator is responsible for all the operations for a product. The work method used in the paper implied data analyze and synthesis, the results were obtained using the Time Measurement Method. Implementing the optimum work method at the production system level results in decreasing the time for the order, in $100 \%$ quality conditions. The research path used in the paper can be used for obtaining some data used for the evaluation of the results, in order for the clothing companies to be certified for the sewing of the specific products, taking in account that, for this type of products, the firms certification is an European request.

Keywords: sewing operations, protective equipment, Time Measurement Method, life security, handling

\section{Creșterea eficienței metodelor de coasere pentru produsele cu destinație specială}

Executarea produselor cu destinație specială necesită rezolvarea a două probleme: asigurarea unui grad ridicat de protecție a consumatorului, dobândit prin proiectare structurală și tehnologică, în conformitate cu destinația produsului și creșterea responsabilității operatorului pentru rezultatul cantitativ și calitativ al lucrării, prin implementarea unor metode riguroase de lucru pentru operațiile de coasere. Rezultatul final va fi eficiența economică a companiilor. Scopul lucrării este de a analiza diferite soluții pentru operațiile de coasere pentru echipamentele destinate transportului grenadelor și al stațiilor radio. Studiul a fost realizat într-o firmă specializată, având particularitatea că, pentru creșterea responsabilizării muncii, un operator realizează toate operațiile de prelucrare pentru un produs. Metoda utilizată în lucrare implică analiza și sinteza datelor, rezultatele fiind obținute prin metoda MTM (Time Measurement Method). Metoda propusă în lucrare poate fi aplicată și pentru alte operații de coasere sau de tratare umidotermică. Transpunerea metodei de muncă considerată optimă la nivel de sistem de fabricație conduce la diminuarea timpului necesar pentru realizarea la termen a comenzii, în condiții de calitate $100 \%$ a produselor obținute. Soluțiile de îmbunătățire, odată implementate, conduc la formarea de automatisme la realizarea secvențelor de coasere. Pentru obținerea rezultatelor estimate în lucrare este necesară îmbunătățirea disciplinei muncii în cadrul firmei.

Cuvinte-cheie: operaţii de coasere, echipament de protecţie, metoda MTM, securitatea vieții, mânuire

\section{INTRODUCTION}

Being part of the European Union implies for the garment manufacturers a new set of restrictions, more and more complex, aiming not only the physical elements of the garments but also the security of the customer's life. Approaching these European problems constitutes for the manufacturers a system of objectives, priorities and instruments, their applicability being a problem of know how transfer, industrial culture and financial resources.

One of the fields that imply the use of these proceedings is constitute by the products for equipments designed to carry grenades or radio stations (figure 1). From the conceptual point of view this type of products must answer the standard functions set, the

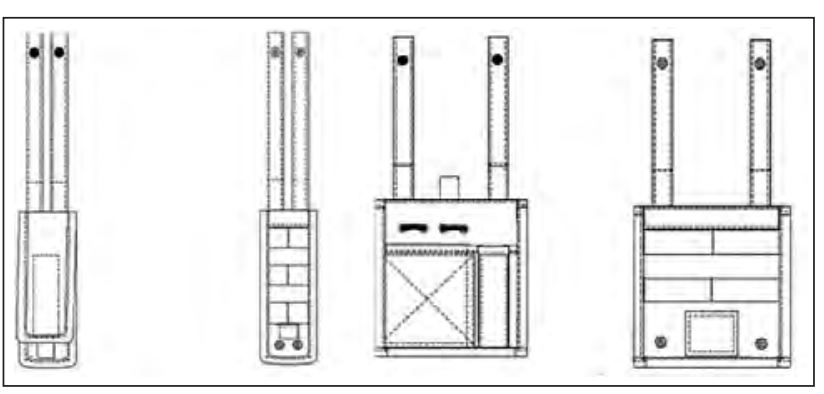

Fig. 1. Equipment for caring grenades or radio stations

differences being in their percentage in the products utility [1]. So, there are important: safety using, functionality and not at last the esthetic function. 
Satisfying the specific functions implies solutions for some technical complex problems, from the designing stage, as following:

- Establishing the proceedings for standard using, for all the customers [2];

- Selecting the raw materials according to the requests, such as: proper behavior at the physical mechanical, stress in using process, superior hygiene characteristics, easy maintenance, attractive color [3-4];

- Selecting the auxiliary materials: tapes, buckles, snaps, Velcro etc. on different criteria as for the clothing products. So, if at the classical products the option is based mainly on the price and aspect, at the products with special destination, the main function is the life security [5];

- The peculiar technical solutions for some of the products functions, materialized by the patterns and technological design [6].

From technical point of view, the following aspects are important:

- Technologies with a high degree of interdependence, with well established following preceding: for example manufacturing group $\mathrm{z}$ is preceded by group $\mathrm{y}$, and its development is conditioned by manufacturing group $\mathrm{x}$;

- Intensive technologies, involving a large number of equipment and methods (established by a decisional process) for every type of product, the combination between these being correlated with the type of the intelligent function (like visibility, communication, sealing).

From the optional criteria point of view, the technologies can be:

- Basic technologies, including the equipment and knowledge compulsory for a product or process, containing documentations, operation specifications, execution schemes, prototypes;

- Unspecific technologies for a product or process, that are the same for every process or product, necessary for manufacturing activity or for knowledge generating (sub components execution plans).

For protective garments it is very important to know and respect these criteria, because of the complexity of this equipment functions and their "hybrid" structure. So, both the basic and unspecific technologies can be traditionally or up to date. Based on the hypothesis that in technological design are always more than one variant for product manufacturing, the accent should be put from just drawing the technological processes to a rational approach, in strong connection with the destination. So, depending on the body area that must be protected, if its exposure to the risk factor varies on the body, the protective function has different dimensional levels and the functional structure of the constitutive elements of the product is different. The garment's functional elements are, at their level, composed of cut pieces, well defined by the characteristics of the raw materials and by their shape [7].
This paper analyzes the case of the classic technological solutions for grenade caring equipment. This paper's objective is to identify solutions for decreasing the time for these types of equipment production.

\section{RESEARCH PATH}

In order to solve the papers' objective, the following steps are followed:

1. General structiure identification of the production system for the studied products (figure 2).

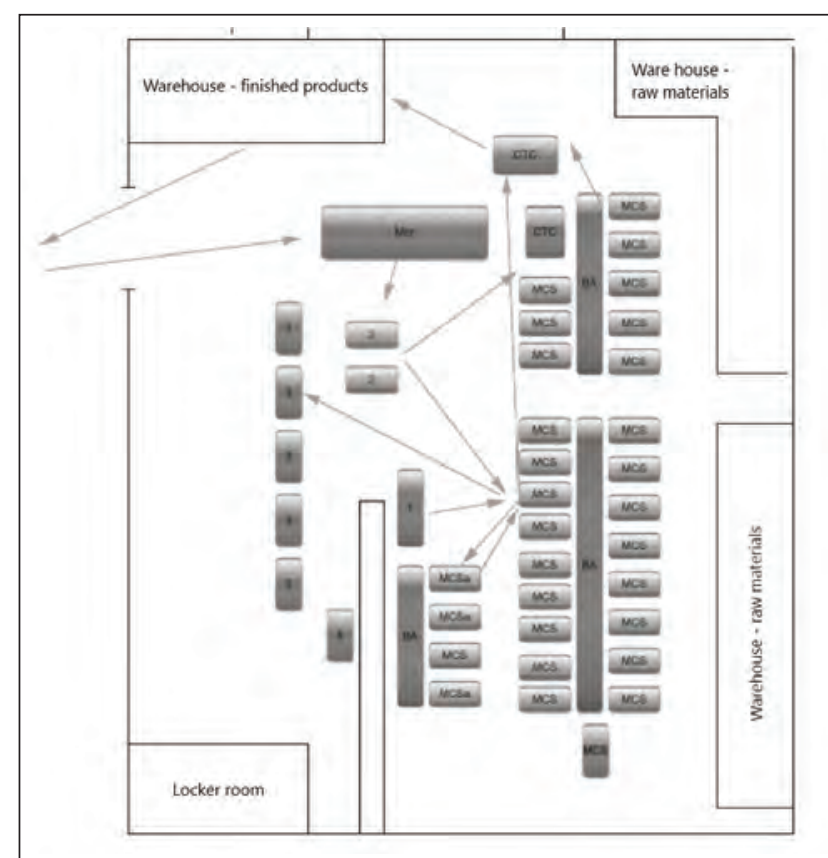

Fig. 2. General structure of the production system for the studied products

2. Sewing operations for the studied products. A sequence of the studied operation is presented in table 1.

3. The analyze of the selected sewing operations reveals the following:

- The operators execute all the operations for one product, in this way increasing the work responsibility, for $100 \%$ quality products.

- The time for the same operations varies from one operator to another (the timing is based on an average of the operation time, from 4 workers, the operators do not depend on the previous or next operation).

- The handling of the sewing parts is difficult, due to the stiffness of the materials, of different structures (PVC impregnated materials, supporting tapes, metallic rings, Velcro) and the different number of layers, leading to variation of the operational times for the same task.

- The frequent needle break affects the time rate, depending on the operator's handling ability (numerous back tacking at the beginning and end of the sewing line).

- Significant differences are at the picking up phase of the sewing operations. The analyzed work places are presented in table 2. 


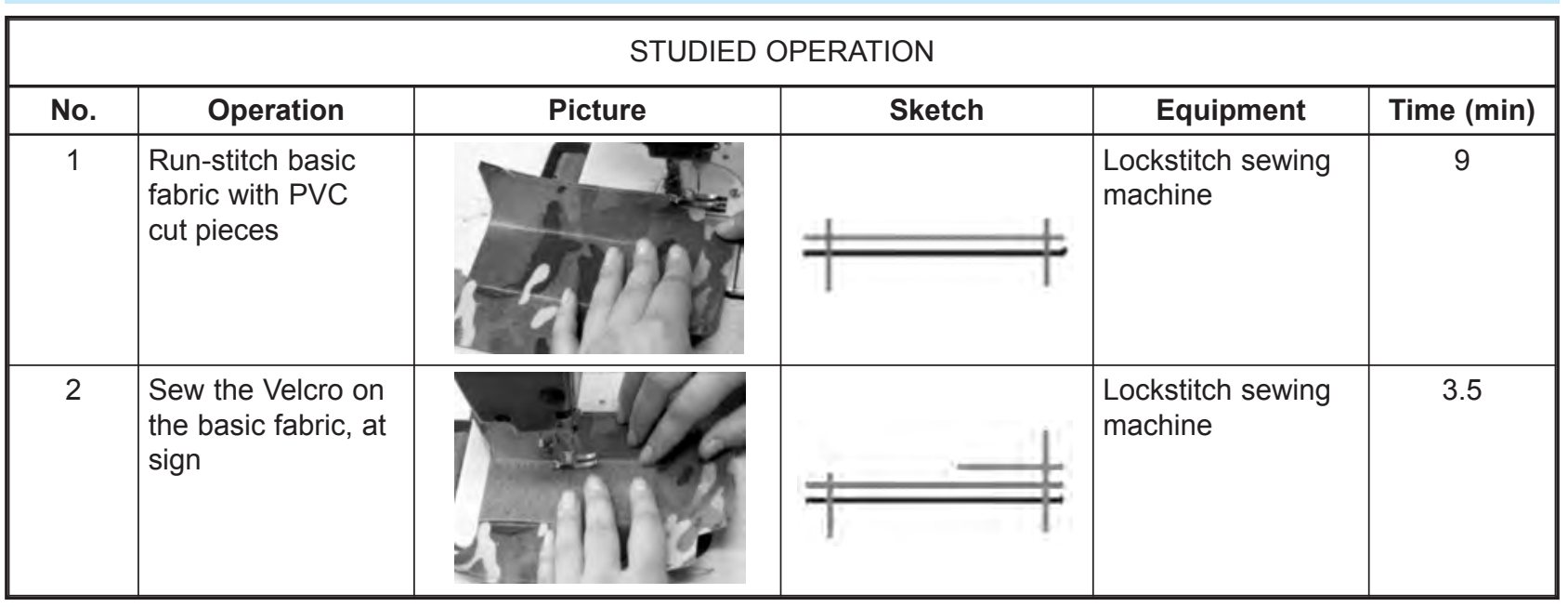

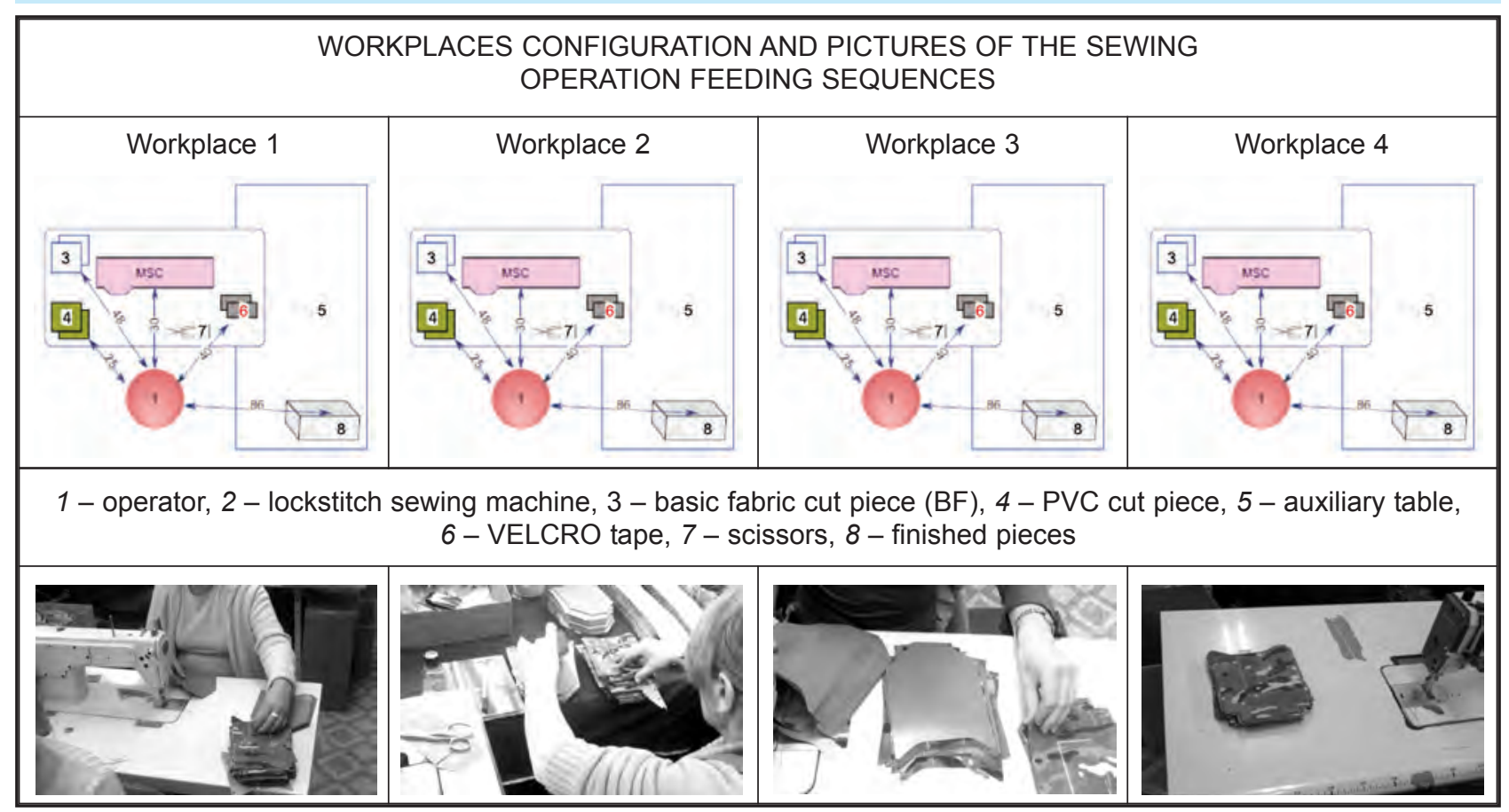

4. Analyze and evaluation of the picking up and placing under the pressing foot of the cut piece of basic fabric and the cut piece of PVC material. The analyze was made at four workplaces. The results (work method and MTM estimations [8]) of the feeding sequence of the sewing operation analyze are presented in table 3 .

Table 3

\begin{tabular}{|c|c|}
\hline \multicolumn{2}{|c|}{ RESULTS OF THE FEEDING SEQUENCE OF THE SEWING OPERATION } \\
\hline $\begin{array}{l}\text { Operator 1: } \\
\text { Preparing the workplace: } \\
\text { Placing the cut pieces of basic fabric (BF) bundle on the } \\
\text { right side of the machine table, } \\
\text { Placing the cut pieces of PVC material bundle on the } \\
\text { right side of the machine table, } \\
\text { Placing the box with the Velcro tape on the right side } \\
\text { Placing some of the Velcro tapes on the right side, under } \\
\text { the back tacking lever, } \\
\text { Placing the scissors on the machine table, } \\
\text { Placing the box for the finished pieces on the left side, } \\
\text { near the chair. }\end{array}$ & $\begin{array}{l}\text { Operator 2: } \\
\text { Preparing the workplace: } \\
\text { Placing the cut pieces of basic fabric bundle on the right } \\
\text { side, on the auxiliary table, } \\
\text { Placing the cut pieces of PVC material bundle on the } \\
\text { right side, on the auxiliary table, } \\
\text { Placing the box with the Velcro tape on the right side, on } \\
\text { the chair, } \\
\text { Placing the scissors on the machine table, } \\
\text { Placing the box for the finished pieces on the left side, } \\
\text { near the chair. }\end{array}$ \\
\hline
\end{tabular}


Working method:

1. Pick the PVC cut piece with left hand. Place on the machine table, in the sewing area,

2. Pick the basic fabric cut piece with left hand. Place upon the PVC cut piece,

3. Check the cut pieces edges,

4. Place under the presser foot.

Estimation of the operational time using MTM method (for 5 pieces)

\begin{tabular}{|l|l|c|c|}
\hline \multicolumn{1}{|c|}{ Basic motions } & MTM & TMU & $\begin{array}{c}\mathbf{t} \\
\text { (min) }\end{array}$ \\
\hline $\begin{array}{l}\text { 1. Reach the left hand, } \\
\text { grab PVC cut piece, } \\
\text { bring the left hand on } \\
\text { the machine table, } \\
\text { positioning PVC } \\
\text { cut piece }\end{array}$ & $\begin{array}{l}\text { (R25A } \\
\text { G1A M25B } \\
\text { P1SE) } \times 5\end{array}$ & 111.5 & 0.067 \\
\hline $\begin{array}{l}\text { 2. Reach left hand, grab } \\
\text { BF piece, move left } \\
\text { hand on the machine } \\
\text { table }\end{array}$ & $\begin{array}{l}\text { (R48A G1A } \\
\text { M485 }\end{array}$ & 201.5 & 0.121 \\
\hline $\begin{array}{l}\text { 3. Positioning BF piece } \\
\text { on the PVC piece, } \\
\text { arrange the edges }\end{array}$ & (P2NSD & 155.5 & 0.093 \\
\hline $\begin{array}{l}\text { 4. Positining the assam- } \\
\text { bly under the presser } \\
\text { foot }\end{array}$ & P2NSD $\times 5$ & 133 & 0.0798 \\
\hline Total & & 601.5 & 0.3609 \\
\hline
\end{tabular}

\section{Operator 3:}

Preparing the workplace:

Placing the cut pieces of basic fabric bundle on the left side of the machine table,

Placing the cut pieces of PVC material bundle on the right side of the machine table,

Placing the box with the Velcro tape on the right side, on a chair,

Placing some of the Velcro tapes on the right side, under the back tacking lever,

Placing the scissors on right, on the machine table,

Placing the box for the finished pieces on the left side, near the chair.

\section{Working method:}

1. Grab the PVC cut piece with right hand from the machine table,

2. Placing the basic piece on the PVC piece,

3. Arrange the pieces edges. Placing the overlapped pieces on the left side of the machine table,

4. Grab the overlapped pieces,

5. Place under the presser foot.

Estimation of the operational time using MTM method (for 5 pieces)

\begin{tabular}{|c|l|c|c|}
\hline \multicolumn{1}{|c|}{ Basic motions } & MTM & TMU & $\begin{array}{c}\mathbf{t} \\
\text { (min) }\end{array}$ \\
\hline $\begin{array}{l}\text { 1. Reach the right hand, } \\
\text { grab PVC cut piece } \\
\text { bundle, bring the right } \\
\text { hand on the machine } \\
\text { table with the PVC } \\
\text { cut pieces bundle. }\end{array}$ & $\begin{array}{l}\text { R48A G1A } \\
\text { M48B }\end{array}$ & 45,9 & 0,0275 \\
\hline
\end{tabular}

Working method:

1. Pick the basic fabric cut piece with right hand from the auxiliary table,

2. Pick the PVC cut piece with left handauxiliary table,

3. Place the PVC cut piece on the basic fabric. Place on the machine table in the sewing area,

4. Check the overlapped cut pieces edges,

5. Place under the presser foot.

Estimation of the operational time using MTM method (for 5 pieces)

\begin{tabular}{|l|l|c|c|}
\hline \multicolumn{1}{|c|}{ Basic motions } & MTM & TMU & $\begin{array}{c}\mathbf{t} \\
\text { (min) }\end{array}$ \\
\hline $\begin{array}{l}\text { 1. Reach right hand with } \\
\text { body rotation and } \\
\text { pieces visualisation, } \\
\text { grab BF piece, bring } \\
\text { right hand on the } \\
\text { machine table, posi- } \\
\text { tioning the piece }\end{array}$ & $\begin{array}{l}\text { (R1A }(80+6) \mathrm{A} \\
\mathrm{M}(80+6) \mathrm{B}\end{array}$ & 302.5 & 0.1815 \\
\hline $\begin{array}{l}\text { 2. Reach left hand, grab } \\
\text { PVC cut piece, move } \\
\text { left hand on the } \\
\text { machine table }\end{array}$ & (R79A G1A & 261 & 0.1566 \\
\hline $\begin{array}{l}\text { 3. Positioning basic piece } \\
\text { on the PVC piece }\end{array}$ & $\mathrm{P} 2 \mathrm{NSD} \times 5$ & 133 & 0.0798 \\
\hline 4. Arrange the edges & $\mathrm{P} 2 \mathrm{NSD} \times 5$ & 133 & 0.0798 \\
\hline $\begin{array}{l}\text { 5. Positining the assam- } \\
\text { bly under the presser } \\
\text { foot }\end{array}$ & $\mathrm{P} 2 \mathrm{NSD} \times 5$ & 133 & 0.0798 \\
\hline Total & & 962.5 & 0.5775 \\
\hline
\end{tabular}

\section{Operator 4:}

\section{Preparing the workplace:}

Placing the cut pieces of PVC material bundle on the right side, on the auxiliary table,

Placing the cut pieces of basic fabric bundle on the left side, on the machine table,

Placing the box with the Velcro tape on the right side, on the chair,

Placing some of the Velcro tapes on the right side, under the back tacking lever,

Placing the scissors on the machine table,

Placing the box for the finished pieces on the right side, near the chair.

\section{Working method:}

1. Grab the PVC cut piece with right handauxiliary table,

2. Grab the basic fabric cut piece with left hand,

3. Place the PVC cut piece on the basic fabric,

4. Check the overlapped cut pieces edges,

5. Place under the presser foot.

Estimation of the operational time using MTM method (for 5 pieces)

\begin{tabular}{|c|c|c|c|}
\hline \multicolumn{1}{|c|}{ Basic motions } & \multicolumn{1}{|c|}{ MTM } & TMU & $\begin{array}{c}\mathbf{t} \\
\text { (min) }\end{array}$ \\
\hline $\begin{array}{l}\text { 1. Reach right hand with } \\
\text { body rotation and } \\
\text { pieces visualisation, } \\
\text { grab PVC piece, bring } \\
\text { the right hand on the } \\
\text { machine table. }\end{array}$ & $\begin{array}{l}\text { (R79A G1A } \\
\text { M79B }) \times 5\end{array}$ & 255 & 0,153 \\
\hline
\end{tabular}




\begin{tabular}{|c|c|c|c|c|c|c|c|}
\hline \multirow[t]{2}{*}{$\begin{array}{l}\text { 2. Reach left hand with } \\
\text { the PVC pieces bundle, } \\
\text { grab PVC pieces } \\
\text { bundle, arrange the } \\
\text { PVC bundle in } \\
\text { cascade, grab PVC } \\
\text { piece with left hand. }\end{array}$} & \multirow[t]{2}{*}{$\begin{array}{l}\text { R2A G1A } \\
\text { P2SE }\end{array}$} & \multirow[t]{2}{*}{20,2} & \multirow[t]{2}{*}{0.0121} & $\begin{array}{l}\text { 2. Reach left hand to the } \\
\text { basic fabric bundle, } \\
\text { grab basic fabric cut } \\
\text { piece, move left hand } \\
\text { and posision it over } \\
\text { the PVC piece. }\end{array}$ & $\begin{array}{l}(\text { R35B G1A } \\
\text { M35A } \\
\text { P1SE }) \times 5\end{array}$ & 180,5 & 0.1566 \\
\hline & & & & \multirow{2}{*}{$\begin{array}{l}\text { 3. Arrange the edges of } \\
\text { basic and PVC fabric } \\
\text { cut pieces. }\end{array}$} & \multirow[b]{2}{*}{ P2NSD } & \multirow[b]{2}{*}{26.6} & \multirow[b]{2}{*}{0.0159} \\
\hline \multirow{2}{*}{$\begin{array}{l}\text { 3. Bring the PVC piece on } \\
\text { the machine table, } \\
\text { releace the PVC piece }\end{array}$} & \multirow{2}{*}{$\begin{array}{l}(\mathrm{M} 2 \mathrm{~B} \text { RL1) } \\
\times 5\end{array}$} & \multirow{2}{*}{20} & \multirow{2}{*}{0.0012} & & & & \\
\hline & & & & \multirow{2}{*}{$\begin{array}{l}\text { 4. Positining the } \\
\text { assambly under the } \\
\text { presser foot. }\end{array}$} & \multirow[b]{2}{*}{ P2NSD × 5} & \multirow[b]{2}{*}{133} & \multirow[b]{2}{*}{0.0798} \\
\hline \multirow{3}{*}{$\begin{array}{l}\text { 4. Reach left hand to the } \\
\text { machine table, grab } \\
\text { basic fabric piece, } \\
\text { bring and overlap with } \\
\text { PVC piece. }\end{array}$} & \multirow{3}{*}{$\begin{array}{l}(\text { R25A } \\
\text { G1A } \\
\text { M25B } \\
\text { P1SE }) \times 5\end{array}$} & \multirow{3}{*}{139,5} & \multirow{3}{*}{0.0837} & & & & \\
\hline & & & & Total & & 595 & 0.3571 \\
\hline & & & & & & & \\
\hline $\begin{array}{l}\text { 5. Grab the bundle with } \\
\text { PVC and basic fabric } \\
\text { pieces overlapped with } \\
\text { both hands and arrange } \\
\text { the bundle, rich the left } \\
\text { hand with the bundle } \\
\text { and place it on } \\
\text { machine table, left side }\end{array}$ & $\begin{array}{l}\text { G1B } \\
\text { P2NSD } \\
\text { M25B } \\
\text { P1SE }\end{array}$ & 47,5 & 0.0285 & & & & \\
\hline $\begin{array}{l}\text { 6. Reach left hand, grab } \\
\text { basic fabric and PVC } \\
\text { pieces, bring to sewing } \\
\text { area. }\end{array}$ & $\begin{array}{l}(\mathrm{R} 25 \mathrm{~A} \text { G1 } \\
\mathrm{M} 25 \mathrm{~B}) \times 5\end{array}$ & 111,5 & 0,0669 & & & & \\
\hline $\begin{array}{l}\text { 7. Positining the assambly } \\
\text { under the presser foot. }\end{array}$ & $\mathrm{P} 2 \mathrm{NSD} \times 5$ & 133 & 0.0798 & & & & \\
\hline Total & & 601,5 & 0,23609 & & & & \\
\hline
\end{tabular}

\section{RESULTS}

The study reveals the following:

a. After the MTM evaluation of the picking up the cut pieces and placing under the foot, at the four workplaces, it can be noticed that the operator from the workplace no. 3 has the best method (minimum time). This method should be extrapolated to the entire operation and to all the 27 sewing machines from the sewing room.

b. Analyzing the feeding phase of the sewing operation of the basic fabric with the PVC material cut pieces, some other improving solutions can be suggested:

b.1. repositioning the bundles with the basic fabric and PVC material cut pieces,

b.2. changing the positioning way for the basic fabric and PVC cut pieces on the machine table at the feeding sequence of the sewing operation.

b.3. changing the sewing method:

- chain sewing (50 pieces), first the right side, with picking up simultaneous the cut pieces from the right side, $10 \mathrm{~cm}$ from the presser foot,

- separation of the sewed pieces (50 pieces),

- chain sewing the left side, placing the bundle at $10 \mathrm{~cm}$ in front of the operator,

- separation of the sewed pieces (50 pieces),
- chain sewing the bottom side, placing the bundle at $10 \mathrm{~cm}$ in front of the operator,

- separation of the sewed pieces (50 pieces). Next, for sewing the Velcro tapes, the bundle with cut tapes must be positioned under the back tacking lever and the bundle with the semi fabricates on the right side, close to the lever. This position allows the pick up, in one move of the right hand, of one Velcro and one semifabricat,

- the eviction of the central element with the Velcro sewed on will be made once at 20-25 overlapped elements, on the left part, at $15 \mathrm{~cm}$,

b.4. replacing the sewing machine with one with thread cutter.

\section{CONCLUSIONS}

Extending the results of the study at the entire company level will decrease the time necessary for getting the order in time, $100 \%$ quality level. The improving solutions, resulted from the work method analyze, implementation lead to:

- Developing of automatism at picking and placing the cut piece under the presser foot;

- Cutting once for 50 pieces, will eliminate the moves of hand reaching for the scissors, bringing the scissors and cutting; 
- No more repositioning of every piece at changing the sewing direction ( 7 repositioning are eliminated for every semi fabricate);
- Training automat motions at methodical placing the elements after sewing and thread cutting.

\section{REFERENCES}

[1] Dulgheriu, I., Avadanei, M., Cozmanciuc, C., Research Concerning the Heat Sealed Treatment parameters Influence on the Main Characteristics of a Doubled Ensemble, In: Tekstil VE Konfeksiyon, 2014, 24, 4, 380-385

[2] Matenciuc, C., Dulgheriu, I., Quality evaluation model for clothing materials, In: Industria Textila, 2011, 62, 2, 99-104

[3] Dulgheriu, I., Cozmanciuc, C., Mechanical tests carried out on composites materials specific to safety jackets, In: Industria Textila, 2012, 63, 2, 97-104

[4] Negru, D., Buhu, L., Dulgheriu, I., Buhu, A., Loghin, E.C., Absorption and moisture transfer through knitted fabrics made of natural and man-made fibers, In: Industria Textila, 2017, 68, 4, 269-274, https://doi.org/10.35530/ IT.068.04.1350

[5] Loghin, C., Nicolaiov, P., et al., Functional design of equipments for individual protection, The $6^{\text {th }}$ International Conference on the Management of Technological Changes, 2009, 2, 693-696

[6] Loghin, C., editor: Îmbrăcăminte funcțională, PIM, ISBN 978-606-520-126-2, lasi, Romania, 2008

[7] Loghin, C., Nicolaiov, P., et al., Work method - Decisional tool for technological change, The $4^{\text {th }}$ International Conference on Management of Technological Changes Book 2, 2005, 53-58

[8] Loghin, C., Nicolaiov, P., Configurarea locurilor de muncă în confecții, Publisher: Performantica, ISBN 978-606-685055-1, lasi, Romania, 2013

\section{Authors:}

\section{IRINA IONESCU, ADELA FLOREA, EMIL CONSTANTIN LOGHIN}

Technical University "Gheorghe Asachi” IASI, Faculty of Industrial Design and Business Management, Department: Knitting and Clothing Engineering, lasi, Romania

Corresponding author:

\section{IRINA IONESCU}

e-mail: iirina@tex.tuiasi.ro 


\title{
The potential of aroma textiles in North-East Romania
}

DOI: $10.35530 / I T .070 .05 .1621$

ANGELA DANILA

VLAD ROTARU

EMIL IOAN MUREŞAN

ALINA POPESCU

\author{
ABSTRACT - REZUMAT
}

\section{The potential of aroma textiles in North-East Romania}

In the last years in the textile industry there is a tendency of orientation towards products with added value. Recent research in the field has shown that the field of aroma therapeutic products is constantly growing due to their advantages: they are environmentally friendly and have beneficial effects on human health and well-being feeling. The present work aims to test the degree of acceptance and potential of aroma textiles (antimicrobial patches, flavoring sheets, anti-cellulite tights and flavoring sportswear) on the market. This research is a market study and comprises two studies: frequency analysis for each variable (22 variables were selected) and verification of working hypotheses (4 hypotheses were chosen) by analysis of variance - One-way ANOVA method. As a quantitative research method, the survey was used and a questionnaire with 26 questions as methodological tool was used. The results of this survey are based on the information provided by the respondents from North-East Romania. The answers included in the survey reflect what the respondents stated. In this study, the following significant aspects were highlighted: high confidence in aroma therapeutic products; the Romanians increasingly prefer textile products with added value, for their health benefits; most interviewees are willing to pay more for textile products with a relaxing effect.

Keywords: survey, frequency analysis, analysis of variance, antibacterial patches, flavoring sheet, flavoring sportswear

\section{Potențialul aromotextilelor în nord-estul României}

În ultimii ani în industria textilă, există o tendință de orientare către produsele cu valoare adăugată. Cercetări recente au arătat că domeniul produselor aromoterapeutice este în continuă creștere datorită avantajelor pe care le prezintă: sunt ecologice și au efecte benefice asupra sănătătii și stării de bine. Scopul acestei lucrări este de a testa gradul de acceptare și potențialul aromotextilelor (plasturi antimicrobieni, cearșafuri cu efect aromatizant, colanți anticelulitici și îmbrăcăminte sport cu efect aromatizant) pe piață. Cercetarea realizată în cadrul lucrării reprezintă un studiu de piață și cuprinde 2 studii: analiza frecvenței pentru fiecare variabilă (22 de variabile) și verificarea ipotezelor de lucru (4 ipoteze) prin analiza de varianță unidirecțională (ANOVA). Ca metodă de cercetare cantitativă s-a utilizat sondajul, iar un chestionar (26 întrebări) a fost utilizat ca instrument metodologic. Rezultatele sondajului sunt bazate pe informațiile furnizate de respondenții din nord-estul României. Răspunsurile incluse în sondaj reflectă ceea ce au declarat respondentiii. În acest studiu, au fost evidențiate următoarele aspecte semnificative: încredere ridicată în produsele aromoterapeutice; românii preferă din ce în ce mai mult produsele textile cu valoare adăugată, pentru beneficiile pe care le prezintă pentru sănătate; cei mai mulți dintre cei intervievați sunt dispuși să plătească mai mult pentru produse textile cu efect relaxant.

Cuvinte-cheie: sondaj, analiza frecvenței, analiză de varianță, plasturi antimicrobieni, cearșafuri cu efect aromatizant, îmbrăcăminte sport cu efect aromatizant

\section{INTRODUCTION}

For the first time, cosmeto-textile concept appeared in 1980 in Japan and at present, cosmeto-textiles is one of the most competitive and dynamic areas of research worldwide and is based on the incorporation of active substances into textiles [1, 2]. The Cosmeto-textile is a technology that merges the cosmetics and the textiles worlds through advanced methods using cyclodextrins, microencapsulation techniques or nanotechnology [3]. In recent years, the number of companies producing cosmeto-textiles and the number of active ingredients incorporated into textile materials is constantly increasing. At present there are a number of textile products in the market with cosmetic properties (moisturizing, slimming, energizing, refreshing, relaxing, vitalizing and
UV protection) [4]. Because textile materials can act as a delivery system, they can be useful for in vivo applications [5]. Often, a cosmeto-textile offers more than an improved comfort, but also a treatment for various skin diseases (supported textiles for venous insufficiency, antibacterial clothing, antioxidant textiles, etc.) [6]. The advantage of using a textile material with cosmetic role is given by the ease of application, replacing the application in the form of ointments / creams / lotions / etc.

In the category of cosmeto-textiles, an important role is played by aroma textiles. In recent years, more and more people come into contact with aroma therapeutic textile materials obtained by applying the essential oils on textile supports.

Essential oils are volatile and they rapidly evaporate from surfaces. From this reason, their embedding in 
suitable shell allows minimizing the evaporation and protecting the oil from high temperature, oxidation and UV light [7, 8]. Most essential oils are used to provide antimicrobial effect to textile support [9]. Most often, in the specialty literature, the essential oils of lemon, chamomile, rose, cinnamon, garlic and jasmine are mentioned [10].

For this study aroma textiles obtained by incorporation four types of essential oils (Thyme essential oil, Lavender essential oil, Mint essential oil and Rosemary essential oil) in different embedding matrices were used. The aim of the research was to evaluate the degree of acceptance and the potential of aroma textiles in north-east Romania.

\section{AROMA TEXTILES ANALYZED IN MARKETING STUDY}

Aroma textile materials (antibacterial patches, flavoring sheet, flavoring sportswear and anti-cellulite tights) for which were analyzed the degree of acceptance on the market were obtained by applying essential oils produced by DOĞAL DESTEK company, Turkey (Rosemarinus Officinalis, Origanum Onites, Mentha Piperita and Lavandula Anguntifolia), in the form of microcapsules or O/W emulsions, at the surface level [11].
GOAL AND OBJECTIVE OF MARKETING STUDY

This study aims to test the degree of acceptance and the potential of aroma textiles on the market from North-East Romania and consumers' preference in choosing a certain type of aroma textile.

Objectives of the study:

- Determining the intention to purchase aroma textile products;

- Determining the purchase frequency of aroma textile products;

- Identification of the selection criteria for an aroma textile product;

- Identification of preferences to a particular type of aroma textile;

- Assessing the amount that potential consumers are willing to spend to buy an aroma textile product.

\section{THE VARIABLES OF THE STUDY}

This research is a market study and comprises two studies.

Study 1: Frequency analysis for each variable

Study 2:

Hypothesis 1: Employment status influences the openness to the use of aroma textiles;

Hypothesis 2: Age influences the type of choosen product;

Hypothesis 3: Gender influences the criteria for choosing a product;

Table 1

\begin{tabular}{|c|c|c|c|}
\hline \multicolumn{4}{|c|}{ THE ANALYZED VARIABLES } \\
\hline No. & Study 1 & No. & Study 2 \\
\hline 1 & Notoriety of aroma therapeutic products & & Dependent variables: \\
\hline 2 & Purchase frequency & 1 & Openness to aroma textile products \\
\hline 3 & The advantages of using aroma textiles & 2 & Preferred product type \\
\hline 4 & Preferred type of aroma therapeutic product & 3 & Criteria for choosing an aroma textile product \\
\hline 5 & Order of antimicrobial patch preference over other products & 4 & Quality \\
\hline 6 & Order of flavoring sheet preference over other products & 5 & Price \\
\hline 7 & Order of flavoring sportswear preference over other products & 6 & Design \\
\hline 8 & Order of anti-cellulite tights preference over other products & 7 & Advertising \\
\hline 9 & Criteria for the selection of aroma textile products & & Independent variables: \\
\hline 10 & The importance of the price indicator & 1 & Employment status \\
\hline 11 & The importance of the quality indicator & 2 & Age \\
\hline 12 & The importance of the design indicator & 3 & Gender \\
\hline 13 & The importance of the publicity indicator & & \\
\hline 14 & The degree of promotion of aroma textile products & & \\
\hline 15 & The price of an antimicrobial patch & & \\
\hline 16 & The price of a flavoring sheet & & \\
\hline 17 & The price of a flavoring sportswear & & \\
\hline 18 & The price of a pair of anti-cellulite tights & & \\
\hline 19 & Gender & & \\
\hline 20 & Age & & \\
\hline 21 & Employment status & & \\
\hline 22 & Income & & \\
\hline
\end{tabular}


Hypothesis 4: The indicators: quality, price, design and advertising, are influenced by employment status.

Variables used in both studies are presented in table 1.

\section{RESEARCH METHODOLOGY}

Quantitative research method used in this study is survey and the questionnaire was used as a methodological tool. The questionnaire (consists of 26 questions) was created as a form in Google Forms (Google Inc.) and was applied from January to August 2019 in lassy. The results of the questionnaire were processed using the SPSS 18 program [12]. The advantages that support the efficiency of the chosen method are: facilitating the extraction of the individuals under study, a low cost and a time to determine the sample, the possibility of a rigorous control of the data collection process. In order to avoid the halo effect (the tendency to respond the same to several questions), a light presentation of the questionnaire was chosen without delimiting by titles the category or dimensions pursued by the question. The sampling method was established using the simple random sampling method, each individual (over 18 years of age) having the possibility to be included in the sample. Questionnaires were mailed out to randomly selected addresses from lassy region.

\section{INVESTIGATED GROUP}

The investigated group was composed of 65 people with different employment status (figure 1). All respondents come from urban areas and are between 20 and 68 years old (figure 2).

\section{RESULTS ANALYSIS}

\section{Study 1}

In order to carry out this study, the method of calculating frequencies in percentages was used. The following are the most important results from the frequency analysis.

Most of the interviewees had heard about the aroma therapeutic products. The results show that $60 \%$ of them have heard of the aroma textiles and $40 \%$ do not know this kind of products. Majority of the respondents have not bought so far aroma textiles, the reasons being different (either the lack of knowledge of this market or the fear of being disappointed with this kind of products). Thus $63.1 \%$ of them has not bought so far aroma therapeutic products, but are interested in them, the same percentage of respondents rarely and never buy aroma therapeutic products (16.9\%) and only $3.1 \%$ of them frequently buy aroma therapeutic textile products. According to a study conducted by the company iSense Solutions, the Romanians' concern about adopting a healthy lifestyle becomes an important one [13]. This fact also results from our study: $66.2 \%$ of the respondents have chosen aroma textiles for their health benefits.

By analyzing variables no. 4-8 we wanted to know which of the four aroma therapeutic products is preferred by those interviewed and which is the order of preferences. Based on the received responses it is observed that the interviewees' preferences decreases in the order: antibacterial patches, sportswear with a flavoring effect, flavoring sheet, anti-cellulite tights. $33.85 \%$ of the respondents placed the antibacterial patch in the first place, $26.15 \%$ of them placed flavoring sportswear on the first place, $24.62 \%$ of the respondents placed the anti-cellulite tights in the first place and $15.38 \%$ of them placed the anti-cellulite tights in the first place.

Analysis of the criterion for choosing aroma textiles has shown that $76.9 \%$ of the interviewees choose products by its quality. From analyzing the preference order of criterion for aroma textiles choice it turned out that $73.8 \%$ of the interviewees put the quality indicator in the first place, $20 \%$ of them put the price indicator in the first place, $4.6 \%$ of those interviewed put the design indicator in the first place and $7.7 \%$ of those interviewed put the advertising indicator in the first place. Regarding the degree of information of the population in relation to the promotion of aroma textiles on the Romanian market, $71.9 \%$ of the respondents believe that aroma textiles have not been sufficiently promoted. From the analysis of the amount that potential buyers would be willing to pay for an aroma therapeutic product, it turned out that most of those interviewed would be willing to pay less than 10 lei (2.2 Euro) for an antibacterial patch, between 50 lei (11.1 Euro) and 100 lei (22.2 Euro) for a flavoring sheet, between 100 lei (22.2 Euro) and 200 lei (44.4 Euro) for a flavoring sportswear and under 20 lei (4.4 Euro) lei for a pair of anti-cellulite tights. According to the obtained results, it was observed that people are willing to pay more (compared to the minimum amount proposed in the questionnaire) for flavoring sheet and flavoring sportswear, which shows that people feel the need for relaxation, and

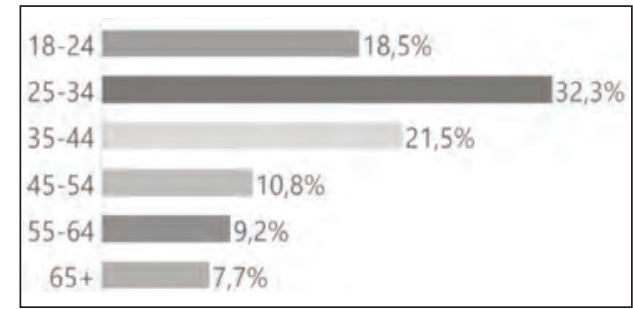

Fig. 1. Age of interviewees

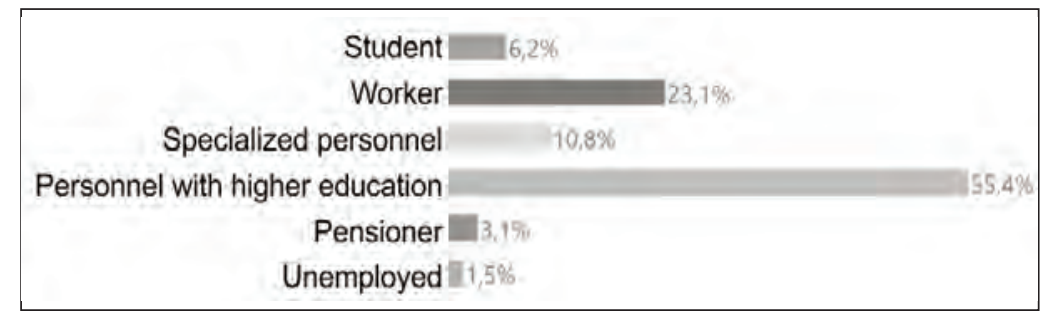

Fig. 2. Employment status of interviewees 
that they are willing to invest in products designed to help them manage stress.

\section{Study 2}

Research Hypothesis 1: Employment status influences the openness to the use of aroma textiles.

With the help of this hypothesis we will check if there exist differences in terms of openness to aroma textile products among respondents with different employment status.

To test this hypothesis the One Way Analysis of Variance (Anova) statistical method was used. According to the results of the analysis of variance (table 2), F, whose value is 3.501 is significant at the level of 0.0077 , since it is less than 0.05 .

Thus, the result obtained allows concluding that the employment status influences the openness to the use of aroma textiles. In conclusion, research hypothesis 1 was validated.

Research Hypothesis 2: Age influences the type of chosen product

The data from the One Way Analysis of Variance (table 3), $F(5,59)=0.293$ and $p=0.9150$, allow to conclude that age does not influence preference over a particular type of aroma textile product.
In conclusion, the research hypothesis 2 was not validated.

Research Hypothesis 3: Gender influences the criteria for choosing a product

According to the data presented in the Anova table (table 4) it follows that the gender variable does not influence the selection criteria of an aroma therapeutic product.

Report $F$ is insignificant at the level of 0.797 . In conclusion, research hypothesis 3 was not validated.

Research Hypothesis 4: The indicators: quality, price, design and advertising, are influenced by employment status

According to the results obtained from the analysis of hypothesis 4 (table 5), it was found that only the indicator "advertising" is influenced by employment status $[F(5,59)=2.754$ and $p=0.0266]$. Interesting is that people with higher education give a greater importance to the indicator "advertising" (11.1\% of them placed the advertising indicator on the first place, $19.4 \%$ - on the second place and $41.7 \%$ - on the third place).

In conclusion, research hypothesis 4 was partially validated.

\begin{tabular}{|l|r|r|r|r|r|c|}
\hline \multicolumn{7}{|c|}{ ONE WAY ANALYSIS OF VARIANCE FOR HYPOTHESIS 1 } \\
\hline & Sum of squares & \multicolumn{1}{|c|}{ df } & Mean square & F & p value & Eta squared \\
\hline Between groups & 7.836 & 5 & 1.567 & 3.501 & 0.0077 & 0.229 \\
\hline Within groups & 26.411 & 59 & 0.448 & & & \\
\hline Total & 34.246 & 64 & & & & \\
\hline $\begin{array}{l}\text { Homogenity } \\
\text { of variance }\end{array}$ & Levene & 0.310 & & & & \\
\cline { 2 - 9 } & p value & 0.9048 & & & & \\
\hline
\end{tabular}

Table 3

\begin{tabular}{|l|r|r|r|r|r|c|}
\hline \multicolumn{7}{|c|}{ ONE WAY ANALYSIS OF VARIANCE FOR HYPOTHESIS 2 } \\
\hline & Sum of squares & \multicolumn{1}{|c|}{ df } & Mean square & \multicolumn{1}{c|}{ F } & p value & Eta squared \\
\hline Between groups & 19.056 & 5 & 3.811 & 0.293 & 0.9150 & 0.024 \\
\hline Within groups & 767.498 & 59 & 13.008 & & & \\
\hline Total & 786.554 & 64 & & & & \\
\hline $\begin{array}{l}\text { Homogenity } \\
\text { of variance }\end{array}$ & Levene & 1.451 & & & & \\
\cline { 2 - 8 } & p value & 0.2195 & & & & \\
\hline
\end{tabular}

\begin{tabular}{|l|r|r|r|r|r|r|}
\hline \multicolumn{7}{|c|}{ ONE WAY ANALYSIS OF VARIANCE FOR HYPOTHESIS 3 } \\
\hline & Sum of squares & df & Mean square & F & p value & Eta squared \\
\hline Between groups & .037 & 1 & 0.037 & 0.067 & 0.797 & 0.001 \\
\hline Within groups & 35.501 & 63 & 0.564 & & & \\
\hline Total & 35.538 & 64 & & & & \\
\hline $\begin{array}{l}\text { Homogenity } \\
\text { of variance }\end{array}$ & Levene & 0.121 & & & & \\
\cline { 2 - 9 } & p value & 0.729 & & & & \\
\hline
\end{tabular}




\begin{tabular}{|l|r|r|r|r|r|c|}
\hline \multicolumn{7}{|c|}{ ONE WAY ANALYSIS OF VARIANCE FOR HYPOTHESIS 4 } \\
\hline & Sum of squares & \multicolumn{1}{|c|}{ df } & Mean square & F & p value & Eta squared \\
\hline Between groups & 10.781 & 5 & 2.156 & 2.754 & 0.0266 & 0.189 \\
\hline Within groups & 46.203 & 59 & 0.783 & & & \\
\hline Total & 56.985 & 64 & & & & \\
\hline $\begin{array}{l}\text { Homogenity } \\
\text { of variance }\end{array}$ & Levene & 1.378 & & & & \\
\cline { 2 - 8 } & p value & 0.2455 & & & & \\
\hline
\end{tabular}

For all hypotheses analyzed, Levene's test does not reject the assumption of equal variances $(p>0.05)$ that is required for ANOVA.

\section{CONCLUSIONS}

The results from marketing study shows that Romanians are increasingly interested in aroma therapeutic products, $63.1 \%$ of them have expressed interest in this kind of products. Although aroma textiles are not sufficiently promoted and people are becoming more and more aware of this fact $(71.9 \%)$, there has been a change in consumer preferences regarding the nature of textile products in recent years. Romanians are increasingly preferring textiles for health care, and this is evident from the results of the questionnaire. Most of the respondents place the greatest emphasis on the quality of the aroma therapeutic products $(76.9 \%)$, and much less on the presentation design of the product (7.7\%). Another aspect analyzed in the study was the choice of the type of aroma textiles from the ones presented. According to the results of the questionnaire, the highest weight is given by the flavoring patch with antibacterial and moisturizing effect (50.8\%), followed by: sportswear with a flavoring effect $(47.7 \%)$, sheets with a flavoring effect $(40 \%)$, tights with anticellulitic effect (35.4\%).

\section{ACKNOLEDGEMENTS}

This work was supported by a grant of the Romanian National Authority for Scientific Research and Innovation, CCCDI - UEFISCDI, project number 29/2018 COFUNDMANUNET III-AromaTex, project title "Manufacturing of value-added textiles for aromatherapy and skin care benefits", within PNCDI III.

\section{REFERENCES}

[1] Roshan, P., Functional finishes for textiles improving comfort, performance and protection, In: Woodhead Publishing Series in Textiles, 2015

[2] Zafar, N., Robin, S., Viennet, C., Humbert, P., Valour, J.P., Agusti, G., Fessi, H., Elaissari, A., Sponge like microparticles for drug delivery and cosmeto-textile use: Formulation and human skin penetration, In: International Journal of Pharmaceutics, 2017, 532, 1, 623-634, https://doi.org/10.1016/j.jpharm.2017.08.122

[3] Taieb, C., Mérhand, S., Bodemer, C., Methods of evaluation, in real life, of the wearing of a cosmeto-textile in the care of infants with atopic skins: Pilot study, In: Journal of the American Academy of Dermatology, 2019, 81, 4, AB94, https://doi.org/10.1016/j.jaad.2019.06.364

[4] Alonso, C., Martí, M., Barba, C., Lis, M., Rubio, L., Coderch, L., Skin penetration and antioxidant effect of cosmeto-textiles with gallic acid, In: Journal of Photochemistry \& Photobiology, B: Biology, 2016, 156, 50-55, https://doi.org/10.1016/j.jphotobiol.2016.01.014

[5] Martí, M., Martínez, V., Rubio, José L., Parra, L., Coderch, L., Antioxidant cosmeto-textiles: Skin assessment, Alonso, C., In: European Journal of Pharmaceutics and Biopharmaceutics, 2013, 84, 192-199, https://doi.org/ 10.1016/j.ejpb.2012.12.004

[6] Hossain, M.A., Benhaddou, A., Pagniez, F., Raymond, M., Le Pape, P., Simard, P., Théberge, K., Leblond, J., Econazole imprinted textiles with antifungal activity, In: European Journal of Pharmaceutics and Biopharmaceutics, 2016, 101, 137-144, https://doi.org/10.1016/j.ejpb.2016.02.003

[7] Rodríguez-Rojo, S., Varona, S., Núñez, M., Cocero, M.J., Characterization of rosemary essential oil for biodegradable emulsions, In: Industrial Crops and Products, 2012, 37, 137-140, https://doi.org/10.1016/ j.indcrop.2011.11.026

[8] Tülay, G., The role of microcapsules in masking bad odors of cotton fabrics, In: Industria Textila, 2017, 68, 4, 275-282, DOI: 10.35530/IT.068.04.1289

[9] Horrocks, A.R., Anand, S.C., Hand-book of Technical Textiles, Published by: Woodhead Publishing Limited in association with The Textile Institute, 2010

[10] Duhamela, N., Martin, D., Larcher, R., Fedrizzia, B., Barker, D., Convenient synthesis of deuterium labelled sesquiterpenes, In: Tetrahedron Letters, 2016; 57(40): 4496-4499 
[11] Dănilă, A., Zaharia, C., Şuteu, D., Mureşan, E.I., Lisă, G., Karavana, S.Y., Toprak, A., Popescu, A., Chirilă, L., Essential mint oil-based emulsions: Preparation and characterization, In: Industria Textila, 2019, 70, 1, 83-87, https://doi.org/10.35530/IT.070.01.1581

[12] Günaydin, K.G., Çeven, E.K., A research on tensile and abrasion properties of fabrics produced from conventional and fire resistant type polyester yarns, In: Industria Textila, 2017, 68, 6, 407-414, https://doi.org/10.35530/ IT.068.06.1484

[13] https://www.isensesolutions.ro/studiu-isense-solutions-romanii-din-ce-in-ce-mai-preocupati-sa-aiba-un-stil-deviata-sanatos/ [accessed 22 August 2019]

\section{Authors:}

\section{ANGELA DĂNILĂ ${ }^{1}$, EMIL IOAN MUREȘAN² ${ }^{2}$ ALINA POPESCU³ ${ }^{3}$ VLAD ROTARU1 ${ }^{1}$, CRISTINA ISTRATE $^{1}$}

1"Gheorghe Asachi" Technical University of lasi, Faculty of Industrial Design and Business Management, 29 Prof. Dr. Doc. Dimitrie Mangeron Blvd, 700050, lasi, Romania e-mail: angela.cerempei@yahoo.com; rotaruvlad1980@gmail.com; cristina.istrate@tuiasi.ro

2"Gheorghe Asachi” Technical University of lasi, Faculty of Chemical Engineering and Environmental Protection, 73 Prof. Dr. Docent D. Mangeron Blvd, 700050, lasi, Romania e-mail: eimuresan@yahoo.co.uk

${ }^{3}$ The National Research \& Development Institute for Textiles and Leather, 16 Lucretiu Patrascanu Str., 030508, Bucharest, Romania

e-mail: alina.popescu@incdtp.ro

Corresponding author:

ALINA POPESCU

e-mail: alina.popescu@incdtp.ro 